Florida International University FIU Digital Commons

FIU Electronic Theses and Dissertations

University Graduate School

$11-13-2007$

\title{
Lions and Roses: An Interpretive History of Israeli- Iranian Relations
}

Marsha B. Cohen

Florida International University, marsha.cohen@fiu.edu

DOI: $10.25148 /$ etd.FI08081510

Follow this and additional works at: https://digitalcommons.fiu.edu/etd

Part of the International Relations Commons

\section{Recommended Citation}

Cohen, Marsha B., "Lions and Roses: An Interpretive History of Israeli-Iranian Relations" (2007). FIU Electronic Theses and Dissertations. 5.

https://digitalcommons.fiu.edu/etd/5

This work is brought to you for free and open access by the University Graduate School at FIU Digital Commons. It has been accepted for inclusion in FIU Electronic Theses and Dissertations by an authorized administrator of FIU Digital Commons. For more information, please contact dcc@fiu.edu. 


\section{FLORIDA INTERNATIONAL UNIVERSITY}

Miami, Florida

\section{LIONS AND ROSES:}

\section{AN INTERPRETIVE HISTORY OF ISRAELI-IRANIAN RELATIONS}

A dissertation submitted in partial fulfillment of the

requirements for the degree of

DOCTOR OF PHILOSOPHY

in

INTERNATIONAL RELATIONS

by

Marsha B. Cohen 
To: Interim Dean Mark Szuchman

College of Arts and Sciences

This dissertation, written by Marsha B. Cohen, and entitled Lions and Roses: An Interpretive History of Israeli-Iranian Relations, having been approved in respect to style and intellectual content, is referred to you for judgment.

We have read this dissertation and recommend that it be approved.

Charles MacDonald

Lesley Northup

Nicholas Onuf

Mohiaddin Mesbahi, Major Professor

Date of Defense: November 13, 2007

The dissertation of Marsha B. Cohen is approved.

Interim Dean Mark Szuchman

College of Arts and Sciences

Dean George Walker

University Graduate School

Florida International University, 2007 
(C) Copyright 2007 by Marsha B. Cohen

All rights reserved. 


\section{DEDICATION}

To my parents, Simon (of blessed memory) and Leah Ball, with love and appreciation. 


\section{ACKNOWLEDGMENTS}

First and foremost, I would like to express my sincere appreciation to the members of my Dissertation Committee. Dr. Mohiaddin Mesbahi, my Major Professor, has been a source of extraordinary support and encouragement. It is to him that I owe the Graduate Assistantship that enabled me to begin my graduate work in International Relations. There are no words to convey my gratitude for the decade of his guidance and encouragement that has brought this dissertation to fruition. I also want to express my appreciation to Dr. Nick Onuf, Dr. Lesley Northup, and Dr. Charles MacDonald for their interest and involvement in my work. Each of my Committee members is a highly respected scholar, outstanding teacher, generous spirited mentor, and an open-hearted human being. It has truly been a privilege working with four such exceptional professors. I truly am grateful to them for their time, their faith in me, and all of their suggestions.

My thanks also go to the International Relations Dept. Chair, Dr. John Clark. I shall very much miss Kathleen Hasselbach, the I.R. Dept. office assistant who has just retired, and I thank her assistance and for her many kindnesses over the year. I also want to express my appreciation to my colleague Hamid Serri for his friendship and assistance.

I am grateful to my mother, to whom this dissertation is dedicated, for being so understanding about the demands of this project on my time. I thank my husband David for "giving me space," and my son, Ian, for his dedicated expert proofreading and computer debugging. I deeply appreciate the love and support of my dearest friends Reza Green and Moshe Silver. Finally, I thank my students in the Florence Melton Adult MiniSchool Graduate class for providing me with a forum to experiment with and to share new approaches in the study and teaching of biblical texts. 


\title{
ABSTRACT OF THE DISSERTATION
}

LIONS AND ROSES:

\section{AN INTERPRETIVE HISTORY OF ISRAELI-IRANIAN RELATIONS}

\author{
by
}

\author{
Marsha B. Cohen
}

Florida International University, 2007

Miami, Florida

\section{Professor Mohiaddin Mesbahi, Major Professor}

This multi-disciplinary research project explores the religious and cultural foundations within the "master commemorative narratives" that frame Israeli and Iranian political discourse. In articulating their grievances against one another, Israeli and Iranian leaders express the tensions between religion, nationalism, and modernity in their own societies.

The theoretical and methodological approach of this dissertation is constructivistinterpretivist. The concept of "master commemorative narratives" is adapted from Yael Zerubavel's study of ritualized remembrance in Israeli political culture, and applied to both Israeli and Iranian foreign policy. Israel's master commemorative narrative draws heavily upon the language of the Hebrew Bible, situating foreign policy discourse within a paradigm of covenantal patrimony, exile, and return, despite the unrelenting hostility of eternal enemies and “the nations.” Iran's master commemorative narrative expresses Iranian suspicion of foreign encroachment and interference, and of the internal corruption that they engender, sacralizing resistance to the forces of evil in the figurative language and myths of pre-Islamic tradition and of Shi'a Islam. Using a constructivist-interpretive 
methodological approach, this research offers a unique interpretive analysis of the parallels between these narratives, where they intersect, and where they come into conflict. It highlights both the broad appeal and the diverse challenges to the components of these "master" narratives within Israeli and Iranian politics and society.

The conclusion of this study explains the ways in which the recognition of religious and cultural conflicts through the optic of master commemorative narratives can complement the perspectives of other theoretical approaches and challenge the conventions of Security Studies. It also suggests some of the potential practical applications of this research in devising more effective international diplomacy. 
CHAPTER $\quad$ PAGE

I. COMPARING THE INCOMPARABLE .........................................

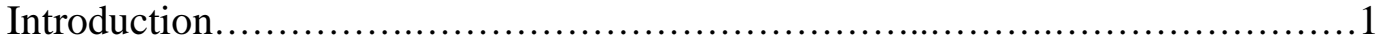

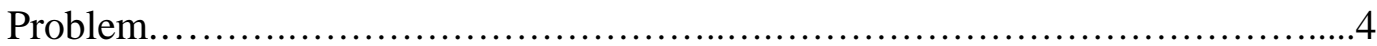

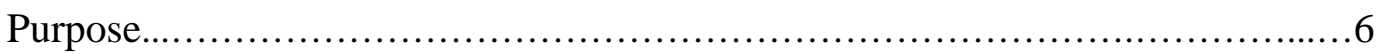

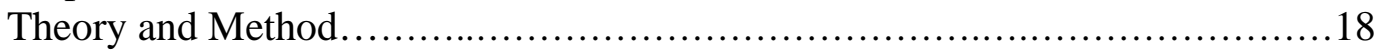

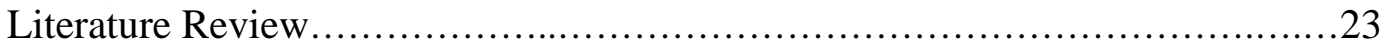

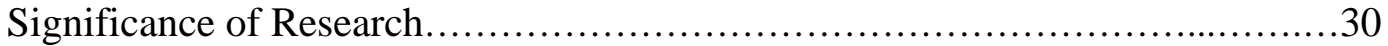

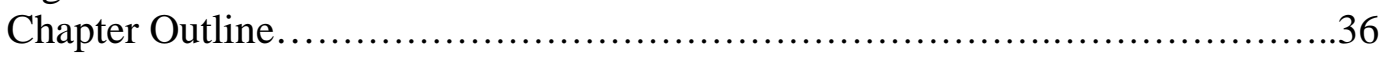

On the Title "Lions and Roses".........................................................40

II. USES OF THE PAST: TEXTS AND CONTEXTS .............................48

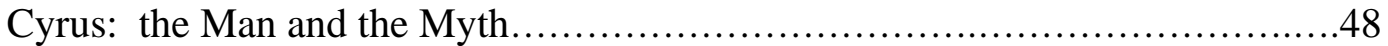

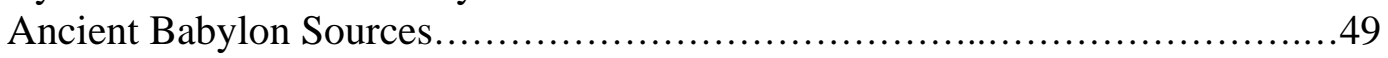

Classical Greece: "Inventing the Barbarian”...........................................53

Jewish Text and Tradition: “Cyrus, My Servant”...................................63

Christian Emancipators and Restorationists: Cyrus Redivivus..................................74

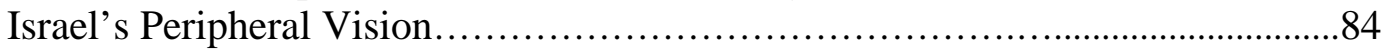

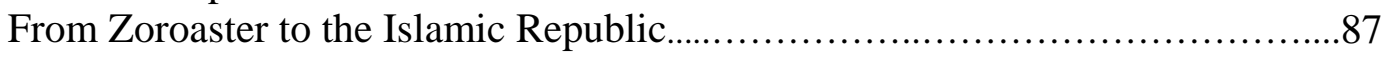

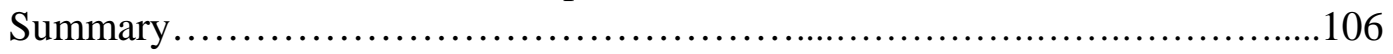

III. CULTURAL AND RELIGIOUS SOURCES OF FOREIGN POLICY............108

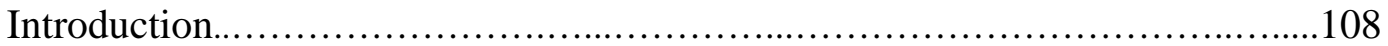

Israel: A People That Dwells Alone..................................................110

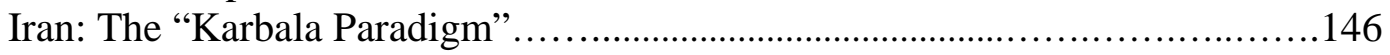

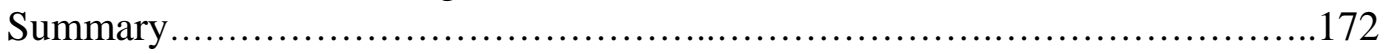

IV. ISRAEL, IRAN AND THE “WAR ON TERROR”:

MASTER COMMEMORATIVE NARRATIVES IN PRACTICE................174

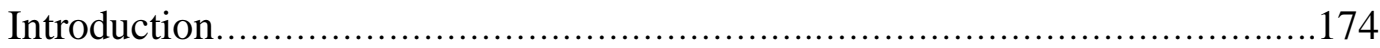

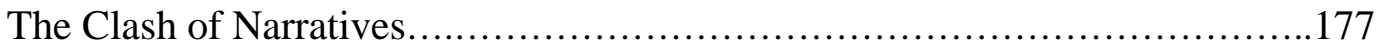

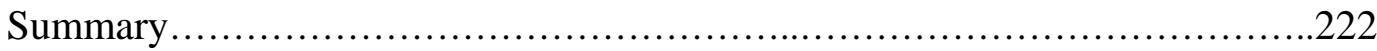

V. CONCLUSIONS: FROM NARRATIVE TO POLICY.............................224

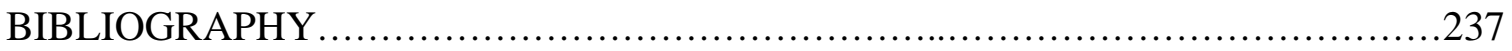

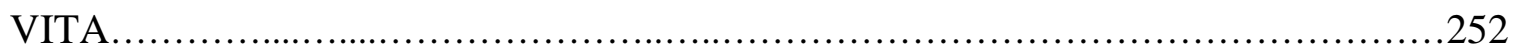




\section{CHAPTER I \\ COMPARING THE INCOMPARABLE}

\section{Introduction}

Iran and Israel share no common border and have no irredentist claims on one another's territory. Both have long been regarded by their neighbors as perpetual outsiders in the largely Sunni Arab Middle East, yet each considers itself to be at the center of the universe. ${ }^{1}$ Both have highly factionalized political systems in which the right and the power to impute value to the actions of the state, to enunciate the state's transcendent political vision, and to articulate the grievances of the state in the international political arena are all strongly contested. ${ }^{2}$

Each asserts the conviction of its own cultural uniqueness and superiority, based upon its continuity with an ancient culture that first formulated and nurtured the highest ideals of civilization. Each views its history through an optic of victimization en route to redemption that mandates exemption from — even defiance of — cosmopolitan ideals and universal norms. $^{3}$ Fueled and justified by narratives of grievance and betrayal in the past

1. According to Jewish legend, the foundation stone (even ha-shatiya) of the universe is located within the Temple Mount in Jerusalem, over which. Solomon's Temple was built. It is presently beneath the Dome of the Rock. See Howard Schwartz, Tree of Souls: The Mythology of Judaism (Oxford and New York: Oxford, 2004), 96-98. Cf. Graham E. Fuller, The "Center of the Universe": The Geopolitics of Iran (Boulder: Westview Press, 1999), 1.

2. Myron J. Aronoff, “Myths, Symbols and Rituals of the Emerging State,” in Laurence J. Silberstein, ed. New Perspectives on Israeli History: The Early Years of the State (New York and London: New York University Press), 177ff. Cf. Daniel Brumberg, Reinventing Khomeini: The Struggle for Reform in Iran (Chicago and London: University of Chicago Press, 2001), particularly chapters 6-7.

3. See, for example, Esther Azolai, "Conquest of the Land: The Moral Dimension," Nekuda 77, August 31, 1984, pp. 18; 31: "There is a qualitative difference between the Torah 
and messianic salvation in the future, both the Jewish state and the Islamic Republic selectively draw upon cultural symbols and myths, ${ }^{4}$ nationalist historiography, and religious texts in constructing a usable past for a state and society unlike any that has ever existed in Jewish or Islamic history. ${ }^{5}$

In few countries is civil society so permeated by religion, even among avowed secularists, with religious and national symbols intertwined. ${ }^{6}$ Paradoxically, however, the heuristic content of shared texts, rituals, symbols, and "the lessons of history" and how they ought to be applied to contemporary domestic politics and international affairs, are also vociferously contested in similar ways. Expressed in Hebrew and Persian, both

morality of the people of Israel and the moral laws of other peoples spread over the earth which are derived from anthrocentric worldviews in which man stands at the center of law and is the highest value. In contrast, the Jewish worldview is theocentric. For the believer the source of both action and belief is the command of God.” Quoted by Ian S. Lustick, For the Land and the Lord: Jewish Fundamentalism in Israel (New York: Council on Foreign Relations, 1988), 121.

4. Use of the term "myth" here and subsequently follows Bascom: "Myths are prose narratives which, in the society in which they are told, are considered to be truthful accounts of what happened in the remote past." William Bascom, "Prose Narratives," in Sacred Narrative: Readings in the Theory of Myth, ed. Alan Dundes (Berkeley et al: University of California Press, 1984.), 9.

5. As Sami Zubaida points out, "There is a dualism in the Iranian state of nation-state concepts intermingled with Islamic forms. These forms are not revivals or continuities with historical instances but quite novel creations. Khomeini's doctrine of velayat $-e$ faqih, for instance, as applied to government, is a major departure from historical Islamic political thought and practice, including Shi'ism. The duality is indicated in the very designation Islamic "republic" (jomhuri). "Republic" represents a link with the French revolution and all the revolutions of this century, in the region and outside, which have toppled a monarchy." Sami Zubaida, “An Islamic State? The Case of Iran,” Middle East Report, no. 153, Islam and the State (July-August 1988), 4.

6. Myron J. Aronoff, “Civic Religion in Israel.” RAIN 44 (June 1981), 4-6. In his conclusion, Aronoff observes that his concept of civic religion might also be applicable elsewhere. He offers Iran as a conspicuous example of another case besides Israel of a society 
ancient languages that have evolved into their present forms while retaining deep layers of historic connotation and nuance, political discourse in both Israel and Iran draws upon vocabulary and imagery from sacred texts that, at one and the same time, resonate as if they were divine fiat, but whose ambiguity allows for considerable interpretive flexibility and ideological disputes.

This research seeks to explore and explain the religious and cultural foundations of the foreign policies of Israel and Iran by examining messages from the past that are conveyed through, inferred from, and justified by sacred text and tradition. It focuses on the various ways that images of the past, expressed in religious symbols and metaphors, are invoked and interpreted as relevant paradigms for the present and the future in the Israeli and Iranian "master commemorative narratives" that contextualize Israeli and Iranian foreign policy discourse. Master commemorative narratives fuse diverse stories about the past into a coherent saga of the formation of a nation—a unified group with a unique character—as it moves through time. " Nationalist movements typically attempt to create a master commemorative narrative that highlights their members’ common past and legitimizes their aspiration for a shared future," one of the most significant mechanisms for constructing a nation’s identity.

which has, or is developing, a religiously based or oriented cultural framework that is becoming ideologically prominent or dominant.

7. Yael Zerubavel, Recovered Roots: Collective Memory and the Making of Israeli National Tradition (Chicago: University of Chicago Press, 1995), 7. 
In the process of recovering the past, a highly selective attitude toward available historical knowledge comes into play. ${ }^{8}$ The dynamic process of recovering memory of the past also requires omission and/or conflation of historic facts-in other words, "forgetting." Drawing upon religious, historiographic, and literary texts, as well as political documents and discourse, this study approaches foreign policy through the optic of ritualized collective memory—“selective memory," "collective amnesia," ${ }^{10}$ and "neglected memory,"11_reflected in these narratives. It identifies and elaborates some of the deep-seated religious and cultural affinities, ambivalences, suspicions, and grievances that have shaped Israeli and Iranian political discourse.

\section{Problem}

This interdisciplinary research explores the framework, as well as the tensions and contradictions, within the "master commemorative narratives" that are the foundations of Israeli and Iranian political discourse. To what extent are cultural conceptualizations expressed in religious imagery, and the historiographic frameworks within which they are depicted, significant factors in the construction, articulation and legitimation of Israeli and Iranian foreign policy? How do parallel tensions within Israeli and Iranian cultures—between "tradition” and "modernity," "collective memory" and "cultural

\section{Zerubavel, 214.}

9. Driss Maghraoui, "Moroccan Colonial Soldiers: Between Selective Memory and Collective Memory-Beyond Colonialism and Nationalism in North Africa," Arab Studies Quarterly 20, no. 1 (Spring 1998), 21-22.

10. Zerubavel, 8.

11. Yaacov Shavit, "Cyrus King of Persia and the Return to Zion: A Case of Neglected Memory.” History and Memory 2, no. 1 (1990), 51-83. 
amnesia," and "utopianism' and "pragmatism"-influence perceptions of the strategic environment, and shape the threats that Israelis and Iranians perceive from one another? In what ways are the narratives, counter-narratives, myths, and ritualized remembrances that articulate these threats reflected and reified in Israeli and Iranian foreign policy discourse?

This study begins from the premise that, for all of their expressed enmity and animosity, Israel and Iran have much in common—historically, politically, culturally, and religiously_particularly in the ways in which religious texts and tenets are used to articulate and legitimate foreign policy goals. This is reflected not only in numerous parallel conceptualizations of religious tradition, modernity, and nationalism, and the tensions between them, but also in the in which seemingly opposing tendencies are mirror images of one another, revealing commonalities in some surprising ways. ${ }^{12}$ For a variety of reasons identified, elaborated and explained within the scope of this project, these commonalities have been forgotten or are deliberately ignored or repressed. The interdisciplinary and multi-disciplinary research presented here supports its thesis that it is the clash of commonalities, rather than a "clash of civilizations," that best explains the hostility between Israel and Iran during recent decades. Paradoxically, however, the recognition of these cultural commonalities might someday have the potential to

\footnotetext{
${ }^{12}$ See Abdolkarim Soroush, “The Three Cultures," in Reason, Freedom and Democracy in Islam: Essential Writings of Abdolkarim Soroush, transl. and ed. Mahmoud Sadri and Ahmad Sadri (Oxford and New York: Oxford , 2000), 156.
} 
overwrite this hostility, were the geopolitical environment to ever make it strategically advantageous for Israeli and Iranian political leaders to reestablish ties.

\section{Purpose}

This research project has several objectives. The first is to challenge the widespread presumption of the singularity, and thus the incomparability, of Israel and Iran with any other states, let alone with one another. Conceptions of the uniqueness of Israel's state and society have long justified the exclusion of Israel from comparisons with other polities and its exemption from numerous categories of conventional classification, and that exclusion is then invoked as further evidence of Israeli exceptionalism: "Neither East nor West, developed nor underdeveloped, capitalist nor socialist, Third World or First World, there is little about Israel that automatically reminds us of other countries and their historical experiences." ${ }^{13}$

Iran shares this resistance to these conventional classification, also resisting designation as “east” or "west,” 14 “developed or undeveloped,” "capitalist or socialist,” and "First World or Third World" on a multiplicity of levels that are similar or parallel to Israel's singularity in a number of ways. Walter Posch points to Iran's unbroken 3,000

13. Michael N. Barnett, "The Politics of Uniqueness: the Status of the Israeli Case," in Israel in Comparative Perspective, Challenging the Conventional Wisdom, ed. Michael N. Barnett (Albany, SUNY, 1996), 3.

14. Ramazani explains that Khomeini's doctrine of "Neither East nor West, only the Islamic Republic" (nah sharq, nah gharb, faqat jumhuri- islami) referred not simply to nonalignment or equidistance from the superpowers, but to ideological opposition to and conflict with the superpowers that have "arrogated all the worldly power (qudrat) to themselves at the expense of the exploited, dispossessed masses of the people everywhere. R.K. Ramazani, Revolutionary Iran: Challenge and Response in the Middle East (Baltimore and London: Johns Hopkins , 1988), 21. 
year national history, to the geographic boundaries that contributed to the sense of Iranian isolation, and the role of the Persian language in culturally unifying much of the vast region between the Ottoman Empire and India, as factors contributing to "Iran's strong, albeit rather schizophrenic, national identity, which is marked by overt self confidence on the one hand and by a deep sense of victimization on the other." ${ }^{15}$ Historic victimization amalgamated with exaggerated self-confidence also characterizes Israel's civil religion, which takes "exaggerated pride in military prowess." ${ }^{\text {"16 }}$ The Israeli Defense Forces (IDF) embodies "the myth of the fighting Jew," and is the centerpiece of Israel's "avenging cult of reprisal" and the "ceremonies and rituals by which the state legitimizes its institutions, cements the loyalty of its citizens, and commemorates its history."17

One manifestation of Israeli and Iranian cultural nationalism is their respective protectiveness of moledet (Hebrew) and vatan (Persian)—-the eroticized, adored feminine geobody of the beloved homeland. ${ }^{18}$ "Constituted as a maternal familial space, vatan became the site for redefining and nationalizing masculinity and its attributes.”19

15. Walter Posch, Introduction, Iranian Challenges, Chaillot Paper 89 (Paris: European Union Institute for Security Studies, May 2006), 10. June 1994.

16. Raymond Cohen, “Israel’s Starry- Eyed Foreign Policy,” Middle East Quarterly,

17. R. Cohen, “Israel’s Starry- Eyed Foreign Policy.”

18. Meron Benvenisti, Conflicts and Contradictions (New York: Vintage Books, 1986), 19-20; David Biale, Eros and the Jews (New York: Basic Books, 1992), 183; Cf. Afsaneh Najmabadi, "The Erotic Vatan [Homeland] as Beloved and Mother: To Love, to Possess, and To Protect, ${ }_{2}$ Comparative Studies in Society and History, Vol. 39, No. 3. (July, 1997), 444-445; Mohamad Tavakoli-Targhi, Refashioning Iran: Orientalism, Occidentalism and Historiography (Houndsmill and New York: Palgrave, 2001), 127-133.

19. Tavakoli-Targhi, Refashioning Iran,132. 
Similarly, the eroticization of labor by the young chalutzim ("pioneers") who came to Palestine from Eastern Europe — building and being built up by agricultural work and physically demanding toil—“was closely bound up with images of the land of Israel as lover, a kind of materialistic transformation of the old allegory of love between God and Israel. $^{20}$ In the biblical Book of Lamentations, an ancient dirge composed about the destruction of Jerusalem by the Babylonians that is recited each year on the $9^{\text {th }}$ of the Hebrew month of Av (Tisha $b^{\prime} A v$ ), the disgraced city of Jerusalem, the "daughter of Zion,” is depicted as a despoiled woman whose "uncleanness clings to her skirts” (Lam. 1:9). In the ghayrat literature of the constitutional revolutionary years of the early twentieth century, foreign intervention has dishonored the chastity of the vatan: "the enemies of the motherland were depicted as rapists” and adulterers [zinakaran]. ${ }^{21}$

Iran is a challenging test case for theories of identity and foreign policy, observes Suzanne Maloney, because it is one of the world's only modern theocracies. Maloney suggests that this raises some interesting questions about the impact of spiritual aspects of identity on a state's security dilemmas, both in general and in the particular case of Islamist ideology: “The literature on Iran typically adopts divergent explanations of this dynamic, either dismissing religion as merely a cynical tool for legitimating state

20 Biale, Eros and the Jews, 183.

21. Tavakoli-Targhi, Refashioning Iran, 128. Saskia Gieling, who translates vatan as "fatherland," states that it has a religious connotation while mihan, another word for fatherland, has a more patriotic connotation. Saskia Gieling, Religion and War in Revolutionary Iran (London and New York: I.B. Taurus, 1999), 152-153. 
interests or, alternatively, interpreting Islamic evangelism and doctrine as the primary determinants of Iran's international agenda."22 Yet, with the exception of Israeli political analysis emanating from what are often disparaged as "liberal," "left wing" or "postZionist” Israeli academics and journalists, scholarly literature tends to overlook the adaptation or manipulation of religious concepts to serve political interests, and often ignores, when it does not embrace, the role of religiously-rooted concepts and national myths in the formation and articulation of Israel's foreign policy.

Israel is, in some respects, a theocracy, with the Hebrew Bible loosely serving as the basis of the secularized civil religion of the Israeli nation, as well as the textual foundation of a broad spectrum of religious interpretations of Judaism (and of Christianity), which shapes (or, as many Israelis and Israel-supporters abroad believe, ought to shape) Israel's foreign policy. Sixty years after its founding, the State of Israel (in contrast to "theocratic" Iran) still has no constitution. Ever since the first constitutional draft was presented to Israel's founders prior to the convening of Israel's first parliamentary session, competing claims about the role of religion in state and society that have framed the debates over "who is a Jew?", and what a "Jewish state" is and ought to be, have proven impossible to reconcile. ${ }^{23}$

Israel's religious parties want to leave open the possibility of imposing of orthodox law (halakha) as the law of the state, while Israel's secular parties of both the

22. Suzanne Maloney, “Identity and Change in Iran’s Foreign Policy,” in Identity and Foreign Policy in the Middle East, eds. Shibley Telhami and Michael Barnett (Ithaca: Cornell University Press, 2002), 89.

23. Baruch Kimmerling, “Danger that lurks in a constitution.” Haaretz, March 31, 2005. 
left and right generally favor some separation of religion and state. ${ }^{24}$ Within the areas of governance over which orthodox and ultra-orthodox rabbis have been permitted to exercise maximum and almost exclusive control over issues of personal status of Jewish Israelis, including marriage, divorce, conversion, as well as defining of "who is a Jew" for any purpose other than immigration under the "law of return," debates over the relationship of religion and state in Israel have no parallel in secular western democracies, although they share some points in common with those taking place in Iran.

Theopolitics and geopolitics reinforce one another, fomenting and mobilizing unconditional opposition to Israel's relinquishing any territory conquered in past or future wars. Many Israelis consider Yesha-- the Hebrew acronym for Judea, (Yehuda), Samaria (Shomron) and Gaza (Aza) — to be part of biblical Israel and the Jewish patrimony promised by God to the Jewish people, and are theologically as well as politically opposed to Israeli withdrawal from any of its presently-held territories and to the "uprooting” of any of the Jewish settlements beyond Israel's pre-war boundaries. According to Rabbi Shlomo Aviner, one of the leading ideologues of Israel's religiousnationalism, "there is an absolute Torah prohibition against the transfer of any portion of our holy land to foreign rule.” Even the Land of Israel not yet ruled by Jews must be acquired at any cost. ${ }^{25}$

The Israeli “new Jew” and the Islamic Republic’s “new Islamic man” are both envisioned as the product of a new utopian, religio-nationalist political order. The

24. Bernard Avishai, The Tragedy of Zionism: Revolution and Democracy in the Land of Israel. (New York: Farrar Straus Giroux, 1985), 185-187. 
idealized muscular Jew envisioned by Israel's secular nationalist founders was conceived of as the antithesis of the stereotypical weak, passive, and "feminine" European Jew of the diaspora who had submitted passively to persecution, pogroms, and extermination. Iran's Islamic revolution set out to create an ideal Muslim man whose daily lifepolitically, economically, legally, and socially—would be structured and oriented around the teachings and values of Islam:

Ridding the Muslim world of its foreign imitations is but a small part of the goal. The top priorities are writing new constitutions, distributing national resources more equitably, and restructuring tax systems so they will be less exploitive or burdensome. These goals have great appeal...The appeal has been reinforced by regular contacts and reinforcements from the clergy, messages of support for the oppressed minorities at Friday prayers and in the media, solutions in the Koran to the questions, big and little, of life. ${ }^{26}$

According to Barry Rubin, "Khomeini and his aides and their allies produced an opposition ideology that that fit their country's historical/cultural predispositions and also supplied a complete set of explanations for Iran's problems."27 Competing conceptualizations of the proper relationship between religious law and the laws of the state continue to shape debates in Israel and Iran over the possibility and desirability of

25. Quoted in Lustick, 95.

26. Robin Wright, Sacred Rage: the Wrath of Militant Islam (New York: Touchstone Books, 1985), 44.

27. Barry Rubin, Paved with Good Intentions: The American Experience and Iran (New York: Penguin, 1981), 272. 
reconciling Judaism or Islam with democracy, and how to balance the imperatives derived from national, religious and modern values. ${ }^{28}$

In both Judaism and Islam, political discourse, when a passage from a sacred text or tradition can be useful in making a point, supporting a position in a controversy, or providing a basis for decision-making, law, or public policy, it is invoked. Sacred texts at variance with policy are ignored or reinterpreted. In traditional Judaism and Islam, reinterpretations take place through textual commentary (midrash in Judaism, tafsir in Islam,) and by deferring to oral tradition (minhag in Judaism, hadith in Islam). The question of who is authorized to invoke or reinterpret a sacred text or tradition for a specific purpose is at the heart of most debates about the nature of religious authority, with rabbis and ayatollahs vying for control of the process of interpretation within a particular context or specific community.

"Religious fundamentalism" is therefore much less about textual literalism than it is about univocality - the insistence that a text or tradition has only one correct meaning, and that only certain arbiters of the law are qualified to ascertain that meaning and how it is to be applied to a given issue or problem. This becomes particularly evident, and problematic, when univocal and multivocal conceptions of religious law battle with one another for acceptance by the state, and in the diasporas beyond its boundaries.

Religion can, and does, inspire extremism and violent action, in defense of deeply held beliefs. ${ }^{29}$ The death sentence imposed Ayatollah Ruholla Khomeini upon British-

28. Abdolkarim Soroush, “The Three Cultures,” in Reason, Freedom and Democracy in Islam: Essential Writings of Abdolkarim Soroush, transl. and ed. ahmoud Sadri and Ahmad Sadri ( Oxford and New York: Oxford University Press, 2000), 156. 
Indian novelist Salman Rushdie in February, 1989, attracted worldwide attention, as did its subsequent reiterations after Khomeini’s death by his successor, Ali Khamenei, and other members of the Iran's religious and political leadership. ${ }^{30}$ Reverberating for nearly a decade in the relations between Iran and Europe, and the non-relations between Iran and the U.S., the "Rushdie fatwa" became equated with, and emblematic of, the religious predilections of the clerical rulers of the Islamic Republic of Iran that did not bode well for Iranian foreign relations.

The political impact of religious violence was immeasurably greater when it resulted in the assassination of Israeli Prime Minister Yitzhak Rabin on November 4, 1995. In the wake of his signing the Oslo Accords, Rabin was denounced by numerous Israeli rabbis, most of whom were paid employees of the Jewish state, as a rodef (a would-be murderer in hot pursuit) and a moser (a Jew who betrays a fellow Jew to gentiles), categories which, according to halakha (Jewish religious law), are designated as deserving of death. The religious logic followed the same principle as that upon which Khomeini had issued his call for pious Muslims to kill Rushdie: in agreeing to turn over the West Bank and Gaza to Arabs, Rabin was endangering the lives of Jews, and had to be stopped by any means necessary. ${ }^{31}$

29. See Ehud Sprinzak, Brother Against Brother: Violence and Extremism in Israeli Politics from the Altalena to the Rabin Assassination (New York: The Free Press, 1999).

30. Richard Bernstein, "Passages in Defense of a Colleague: Writers Read and Speak for Rushdie,” New York Times, Feb. 23, 2989.

31. Haim Cohen, “Dangerous Halakha.” In Free Judaism \& Religion in Israel, ed. Yaakov Malkin (Farmington Hills, MI: Free Judaism, 1998), 41-43; Sprinzak, 244-285. 
The man arrested for Rabin's assassination, Yigal Amir, used as his defense in court the argument that "According to Jewish law, the minute a Jew betrays his people and country to the enemy, he must be killed." 32 No specific rabbi could be identified as having given Amir explicit permission to assassinate Israel's Prime Minister. Indeed, several rabbis who had signed the decision declaring Rabin a moser deserving of death professed shock that their religious rulings might be taken literally as a license to kill. Nevertheless, when thirty of the most highly regarded rabbinic authorities (most, if not all, of whom were employees of the Jewish state), were asked whether or not Yitzchak Rabin was a moser according to Jewish law (halakha), not a single one offered a negative response. ${ }^{33}$ Many Israelis felt that the very act of issuing such rulings created the climate for extremist violence.

A year and a half earlier, on February 25, 1994, Baruch Goldstein, an Orthodox Jewish settler, had opened fired on five hundred Muslims as they knelt in prayer for Ramadan at the Cave of the Patriarchs in Hebron. Goldstein killed twenty nine Muslims and wounded one hundred others, before he was overcome by worshippers when his rifle jammed and beaten to death. Goldstein's action was widely perceived by his closest associates and the religious-nationalist community in Israel as an act of martyrdom. ${ }^{34}$

32. Joel Greenberg, "Israeli Police Question Two Rabbis in Connection with Rabin Assassination,” New York Times, November 27, 1995.

33. H. Cohen, "Dangerous Halakha,” 45.

34. Sprinzak, 1. 
Long believed to be "an island of democracy, secularism, pragmatism, and nonviolence," Israel was widely regarded as an exception to the violence associated with religious radicalism elsewhere in the Middle East. ${ }^{35}$. Since the 1980s, the emergence of the radical Kahanist "culture of violence," and its overlap with elements of the messianically-driven Gush Emunim ("Bloc of the Faithful) movement, challenges this assumption. Furthermore, it raises questions about some deeply cherished verities about Israel's “opaque” and undeclared nuclear program.

It is only relatively recently that empirical and quantitative academic researchers have begun to analyze either Israel or Iran in comparison with any other societies and polities, let alone with each other. The 1990-93 World Values Survey, which gathered and cross-culturally examined survey samples from 40 countries representing $70 \%$ of the world's population, included neither Israel nor Iran. However, more recent surveys conducted between 1999-2002 now provide at least some empirical data on numerous questions that can be usefully applied in quantitative trans-national and cross-cultural comparisons between Israel and Iran (although the number of issues for which Israeli data is available through the World Values Survey remains quite limited). ${ }^{36}$

Within, and beyond, demonstrating the possibility of constructing a broad but nuanced and detailed constructivist-interpretive framework to demonstrate that the "unique" cases of Israel and Iran may indeed be productively compared as well as contrasted with one another, the research objectives of this project are:

35. Sprinzak, 6.

36. Ronald Inglehart, Human Beliefs and Values : A Cross-cultural Sourcebook Based On the 1999-2002 Values Surveys (eBook, México Siglo XXI, 2004). 
1. To compare the ways in which Israelis and Iranians utilize sacred text, myths, tradition, national-religious historiography, and "selective memory" to construct and promote their identification with ancient cultures, traditions, and historic grievances. These myths play a foundational role in the construction of their present-day political narratives and foreign policy. Manochehr Dorraj observes, "Political events do not occur in a vacuum; they take place in a cultural context by which they are sanctioned, and in turn those political events modify cultural norms and sacred symbols." ${ }^{37}$ It is in the ways in which religious historiography and vocabulary are employed in constructing these cultural contexts, and present-day political events interpolated into their respective mythic, religious, and historiographic teleologies that, this study argues, Israelis and Iranians exhibit the most similarities in their foreign policy discourse. Although the institutional structures that shape and reflect these contexts are quite different, identifying and understanding the "hermeneutic trajectory" animating each of these narratives makes it possible to better understand the religious and cultural underpinnings of current IsraeliIranian enmity. ${ }^{38}$

2. To demonstrate the application of the theoretical and conceptual framework of "master commemorative narrative" that illustrates the pervasiveness and salience of competing interpretations of religious concepts, myths and symbols in Israeli and Iranian political consciousness and discourse. Acts of commemoration, whether they reinterpret

37. Manoucher Dorraj, From Zarathustra to Khomeini: Populism and Dissent in Iran (Boulder and London: Lynne Rienner, 1990), 4. 
ancient and medieval practices (e.g. Purim and Ashura), or create new commemorations under religious auspices, with or without state sponsorship, such as Yom HaShoa (Holocaust Remembrance Day) and Quds (Jerusalem) Day in Iran, regenerate and revivify the commemorative aspects of the master narrative. Such events are marked by the development of new religious and political rituals and "invented traditions." Furthermore, when recognized and commemorated as typological events and turning points, these events may move to the forefront of what Yaacov Shavit calls "active historical memory," emblematic of a period in history, with an analogical status, that is being reenacted in the present.

3. To highlight the ways in which Israeli and Iranian leaders responded to the U.S. "War on Terror" rhetoric and its neo-Manichaean overtones as a challenge as to one another, as well as to domestic opponents. In this study of the period between September 11, 2001 and U.S. President Bush’s “Axis of Evil” State of the Union address on January 29, 2002, I provide a content analysis of published statements by politicians and other politically influential individuals to highlight specific examples of the tacit presence of the "master commemorative narratives" in this discourse.

This research also points out the interconnection of the two most contested issues in the Israeli-Iranian relationship: the Palestinians and nuclear technology. From the Israeli perspective, the threat posed by Iran gaining nuclear capability gains shrillness and becomes front page news whenever Israel is under pressure to make any concrete

38. Jonathan Boyarin, “Reading Exodus Into History,” New Literary History 23, No.3, Summer 1992, 524. 
territorial concessions to the Palestinians. On the Iranian side, political support for the Palestinian cause and charges of western hypocrisy regarding the Iranian right to nuclear technology move to the forefront during domestic power struggles.

4. To highlight the ways in which Israelis and Iranians use the negative stereotypes of one another to brand and demonize domestic, as well as foreign, political opponents. Iranian opponents of rapprochement with "the west", and particularly with the U.S., accuse proponents of being Zionist counter-revolutionaries. Secular Israelis, resentful of the growing power of orthodox and ultra-orthodox parties and factions, point out the resemblance of Israel's politically powerful rabbis to their counterparts in Iran's clerical establishment. Religious factors also shape U.S. responses toward, and as an audience for, Israeli and Iranian foreign policy rhetoric, which elicit diametrically opposite responses from the U.S. This research explores the extent to which Israel's competitive advantage in eliciting positive responses to its foreign policy from the U.S., as well as U.S. negativity toward Iran, derives from elements of the U.S.'s own “master commemorative narrative.”

5. To suggest some of the ways in which a deeper and broader understanding of the religious, historical, and cultural components of the constructions of the past and “commemorative narratives” can expand and enrich the field of International Relations.

\section{Theory and Method}

The theoretical and methodological approach to this research is constructivist and interpretive. Epistemologically, it is predicated on the assumption that what is, and what can be, known by social actors about the past, recent as well as ancient, is 
always mediated through interactive historiographic processes that give form and meaning to events in the ongoing process of transmitting and commemorating them.

Michael Kammen observes, "Critics adhering to diverse ideological persuasions have suggested that societies in fact reconstruct their pasts rather than record them, and that they do so with the needs of contemporary culture clearly in mind..."39 By participating in the recollection and commemoration of events in the past that they, as individuals, may not personally have experienced, members of a society or polity acquire identity and assert solidarity. In their contributions to the structuring and observance of collective commemorative events, and to national historiography through their policy statements, speeches, memoirs, and other public commentary, political leaders vie with one another for adherence to their own particular constructions of the past and visions of the present and future. This study draws upon a vast and diverse body of academic literature that deals with the social construction of collective memory in nationalist movements that continues in post-modern cultural analysis, while focusing specifically on the practical application of these conceptualizations to analyzing foreign policy in Israel and Iran.

My research extends and applies the analytical framework of Yael Zerubavel's study of ritualized remembrance within the Israeli domestic political sphere ${ }^{40}$ to Iran, and to the role of "master commemorative narratives" in both Israeli and Iranian foreign policy. A synthetic, constructivist-interpretive methodology is employed in the analysis

39. Michael Kammen, Mystic Cords of Memory: The Transformation of Tradition in American Culture. (New York: Vintage Books, 1993), 3. 
of the "master commemorative narratives" underlying political speeches, interviews and documents, and literature. Dvora Yanow, among the foremost proponents of interpretative policy analysis, emphasizes that analysts, policymakers and other actors in policy, organizational, and community situations are telling stories, whether for purposes of argument or claims making. These require new modes of narrative analysis beyond the conventions of what is generally as qualitative research. ${ }^{41}$ By integrating the analytical tools provided by discourse analysis ${ }^{42}$ and hermeneutics, and applying them to foreign policy, my study seeks to identify and contextualize the use of historiographic and religious references whether explicit, implicit, or embedded. ${ }^{43}$

Both the State of Israel and the Islamic Republic of Iran are living laboratories where ethno-religious myths and symbols gleaned from sacred texts and tradition have been drafted, armed, and placed in the frontlines of political change, social mobilization and national security during the course of the past half century. It is precisely these national myths that define the boundaries between self and other that are the focus of the research presented here. In both Israel and Iran, perceived contemporary threats to the survival of the state from its enemies are depicted as reenactments and recapitulations of flashpoints in sacred history. I compare and

40. Zerubavel, 3-36.

41. Dvora Yanow, Conducting Interpretive Policy Analysis (Thousand Oaks: Sage Publications, 2000), 58.

42. Ole Waever, “Discourse Analysis as Foreign Policy Theory,” Columbia International Affairs Online (CIAO). http://www.ciaonet.org/wps/wao01/index.html (accessed March 15, 2007). 
contrast the ways in which political leaders of Israel and Iran utilize carefully chosen images from sacred texts and cultural myths in their "master commemorative narratives" in shaping their constructions of self and other in political discourse. These constructions, reinforced through religious ritual and state-sponsored "invented" traditions, in turn influence the ways in traditional texts are read and understood in a contemporary context. Furthermore, I examine the ways in which political and religious leaders appropriate and synthesize events and personalities into an explanatory discursive paradigm that shapes and justifies foreign policy decisionmaking.

The adaptation and application of interpretive approaches from social history, as well as than social science, comparative literature alongside comparative politics, and Religious Studies alongside Security Studies, opens up a vast array of possibilities within the field of International Relations and new opportunities to be explored by foreign policy analysis. The major deficiency with standard social science models in analyzing how specific states make strategic decisions, according to Caroline Ziemke, is that events are plucked out of their historical context and measured against a general theoretical model, ignoring "a whole complex of motives, preferences, beliefs, prejudices, and ways of thinking that have deep roots in history.” States, like individuals, use their unique historical experiences that are stored in their national myths and symbols of identity to define the boundaries between self and other, and to guide their social and political life. These myths and symbols are more significant for

43. Yanow, 4. 
their motivational power than for their historical accuracy. Analysts and policy makers who ignore them, Ziemke observes, tend to "dismiss the state's behavior as a willful attempt to flaunt international norms, or somehow irrational." ${ }^{44}$

"Rational choice theory" in the field of International Relations has revealed its limitations as well as its steadily declining relevance to policy formulation in recent years, most conspicuously with regard to foreign policy towards the Middle East. ${ }^{45}$ The types of data generated by statistical analysis are proving inadequate and incapable, in and of themselves, for predicting, recognizing and dealing with the diplomatic and strategic challenges of the $21^{\text {st }}$ century. There is growing recognition of the need to develop and apply new qualitative research methodologies, particularly in research areas involved with the dynamics of religious influence on politics. Unprecedented attention is now being given to interdisciplinary perspectives and methodologies from history, philosophy, cultural studies, anthropology, and theology "in a shared quest to understand the relationship of religion and politics, especially the roles that religion plays and will play in the public life in the years to come." 46 It is hoped that the research presented here will contribute to this quest.

44. Caroline F. Ziemke, “The National Myth and Strategic Personality of Iran.” In The Coming Crisis: Nuclear Proliferation, U.S. Interests, and World Order, ed. Victor A. Utgoff , BCSIA Studies (Cambridge: MIT Press, 2000) 88.

45. See Jonathan Cohn, "Irrational Exuberance: When Did Political Science Forget about Politics?” The New Republic, October 25, 1999. 25-32.

46. American Political Science Association website, Call for Papers, 2007, Section 33, Religion and Politics. http://www/a[samet/prg/content_6317.cfm (accessed Nov. 15, 2006). 


\section{Literature Review}

Nearly all the available literature in the field of International Relations on IsraeliIranian relations is predicated upon a Realist theoretical paradigm. Among the key features of this paradigm are a state-centric approach to international politics and the assumption of the state as a unitary actor, whose voice is that of its capital city and/or its head of state, irrespective of domestic policy debates and challenges to the legitimacy of the regime in power. The most singular characteristic of the Realist paradigm is the assumption that all states act in order to best serve their national interests and to maximize their security and power. Differences and changes in domestic leadership or of ruling party are generally considered relevant to foreign policy only insofar as these changes reflect, or require, realignment of alliances and/or the methods of enhancing power and security that impact external relations.

One of the ways states maximize their security is by forming alliances in order to prevent larger powers from dominating them. During the 1953-1979 period in IsraeliIranian relations, Israel and Iran, two non-Arab states in the largely Arab Middle East dominated by Arab states, are generally depicted as having formed an alliance, even a "friendship," notwithstanding the Realist maxim that "states have no friends, only interests.”

There have been surprisingly few studies of the relationship between Israel and Iran, and even fewer which extend into the post-Khomeini decade of the 1990s and the twenty-first century. One notable and important exception is the cutting-edge research of Trita Parsi. In his most recent work, Treacherous Alliance, Parsi challenges many of the longstanding assumptions about the "friendliness" that characterized Israeli and Iranian 
relations during the reign of Shah Mohammed Reza Pahlavi. ${ }^{47}$ By the early 1970s, Parsi explains, the Shah's top priority was cultivating ties with the Arab states, particularly Egypt.

Israel, however, did everything it could to prevent a thaw in relations between Iran and Egypt and to subvert the Shah’s “Arab option” by publicizing his close ties to Israel. Based upon interviews with Iranian and Israeli officials who participated in the decision-making processes in the 1980s and 1990s, Parsi is able to provide the most sophisticated approach to the Israeli-Iranian relationship from a Realist perspective. Parsi chronicles the negativity toward Iran that began to characterize Israeli policy towards Iran in the early 1990s, after the death of Khomeini, just as Iran’s policies seemed to be on the verge of moderating.. Having served for nearly a decade as Iran's source of armaments in the Iran-Iraq war, in the 1990s "Israel wanted to put Iran under economic and political siege” and preempt any possibility of U.S.-Iranian dialogue.”48

Until the recent publication of Parsi's work, Sohrab Sobhani's The Pragmatic Entente: Israeli-Iranian Relations, 1948-1988 had been the most detailed analysis of the interactions of Israel and Iran both before and after the Islamic revolution from a Realist orientation. Sobhani describes Israeli and Iranian relations, during the waning years of the Shah's regime, as “deep and diverse, based on a persistent, resilient, and durable convergence of geopolitical, military and economic interests.” On the Iranian side, this served to counter both Soviet influence and Arab radicalism, while providing a market

47. Trita Parsi: Treacherous Alliance: The Secret Dealings of Israel, Iran, and the U.S. (New Haven: Yale. University Press, 2007) 39-78.

48. Parsi: Treacherous Alliance, 181. 
for the sale of Iranian oil, obtaining Israeli military and economic development assistance, and providing the Shah with a useful and influential intermediary with Washington. From the Israeli perspective, the peripheral strategy and concern for Iranian Jews were the dominant considerations. ${ }^{49}$ The fate of Iranian Jewry would also be a factor in the Israeli government's decision to provide military equipment to the Islamic Republic, along with the major importance of arms exports to Israel's economy. ${ }^{50}$

Sobhani had predicted that the future of the Israeli-Iranian "pragmatic entente" would remain "a mixture of tactical cooperation...tempered by ideologically motivated disagreements" ${ }^{51}$ until such time as the Iranian regime could be overthrown or might otherwise disappear, and when, in the words of then-Defense Minister Yitzhak Rabin, "this crazy idea of Shi'ite fundamentalism is gone." ${ }^{\text {52 }}$ By the early 1990s, within five years of the conclusion of his research, the Soviet Union had collapsed, the Iran-Iraq war ended, and the "unipolar moment" made possible a U.S. drive for hegemony in the Middle East. Key variables that Sobhani had regarded as constants and conducive to a “durable convergence of interests” between Israel and $\operatorname{Iran}^{53}$ were no longer applicable.

Khomeini and Israel, a slim tract by an Iranian journalist, Behrouz Souresrafil, published in 1988, argues that Israel and the Khomeini regime continued to cooperate

49. Sohrab Sobhani, The Pragmatic Entente: Israeli-Iranian Relations, 1948-1988 (New York: Praeger, 1989), Sobhani, 135-136.

50. Sobhani, 146.

51. Sobhani, 171.

52. Sobhani, 149.

53. Sobhani, 171. 
closely even after the fall of the Shah because Israel's Likud government, under the leadership of Menachem Begin, had been hostile to the Shah. Israel stood to benefit from the Shah's downfall because Iran's army, the only Middle Eastern capable of a seriously challenging Israel, would be weakened and would no longer pose a threat to Israeli regional preeminence. According to Souresrafil, Israel viewed Khomeini's revolution as changing the balance of power in the Middle East, thereby destabilizing the Arab regimes most hostile to the Jews. ${ }^{54}$ While Khomeini and Israel, published a year before Khomeini's death, is redolent of some of the darker conspiracy theories that abound in the Iranian press, Souresrafil’s conclusions are not very different than Sobhani’s.

Souresrafil's account of the support Khomeini's revolution received from radical Palestinian groups is also attested to by Israeli political columnist Samuel Segev, a captain in Israeli army intelligence. Various Palestinian factions with diverse Iranian political groups opposed to the Shah. ${ }^{55}$ Iran tends to be portrayed in academic literature as well as the media as the sponsor of rejectionist Palestinian groups, influencing, motivating, and radicalizing them, rather than the other way around. Souresrafil and Segev disagree about Israel's motives in selling weapons to Iran during the 1980s, particularly in the Iran-Contra "arms for hostages" debacle; Souresrafil, like Sobhani, says that apart from strategic and geopolitical considerations, economic considerations were Israel's primary motive. Segev contends Israel's primary interest was keeping a

54. Behrouz Souresrafil, Khomeini and Israel (I Researchers Inc., 1988), 38.

55. Samuel Segev, The Iranian Triangle: The Untold Story of Israel's Role in the IranContra Affair (New York: Free Press, 1988), 116-119. 
channel open to Iran until such time that regime change would make a resumption of Iranian-Israeli ties possible. $^{56}$

David Menashri is one of the proponents of what Parsi calls the "ideological" view of the Israeli-Iranian relationship. Religious factors are at the forefront of his analysis of the treatment of Jews in Iran from Zoroastrian time to the Qajar era (17961925), when Western travelers quoted by Menashri reported the poverty, ignorance and persecution of Iranian Jews to the Islamic revolution. ${ }^{57}$ Shi'ite xenophobia branded unbelievers as unclean, and capable of defiling Muslims with ritual impurity. Midnineteenth century travelers to Persia described the physical separation and social segregation and economic limitations on Jews, including laws which forbade Jews going out on rainy or snowy days because the water might contaminate Muslims with Jewish impurity.

The Pahlavi era was a marked improvement for Iranian Jews, and the Shah's “White Revolution" which began in 1953 was the "Golden Age” of Iranian Jewry, offering them political freedom and equality, economic progress, and cultural, educational and religious autonomy. It was the Pahlavi era, according to Menashri, that was exceptional in Persian Jewish history, rather than the changes that took place after the Islamic revolution, after two thirds of Iranian Jews fled the country. Just prior to the fall of the Shah, Iran’s Jewish community was “free, educated and wealthy. Their part in

56. S. Segev, 302.

57. David Menashri, "The Jews of Iran” Between the Shah and Khomeini," in AntiSemitism in Times of Crisis, ed. Sander L. Gilman and Steven T. Katz, (New York and London: New York University Press), 354-355. 
economic, scientific and professional life was disproportionate to their share in society...In per capita terms, they may well have been one of the richest Jewish communities worldwide...” Young Jews were highly educated, and overrepresented in the student population, university faculty members, and the professions such as medicine. All of these assets turned to liabilities in the fall of 1977, their attachment to Israel, Zionism and U.S. "imperialism" made them targets of the new regime. Within the community itself a fissure erupted between young leftist intellectuals and the traditional leadership. ${ }^{58}$

Menashri characterizes the Iranian government’s policy towards Jews during the Khomeini years as "the precarious combination of instigation and restraint." He also points out Israel’s eagerness “to lead anti-Iranian camp, just as much as Iran undertook to lead the anti-Israel camp" of the Muslim world. Iran has remained "excessively uncompromising” in its unequivocal rejection of Israel's legitimacy and its hostility toward Zionism, while Israel has no less vehemently portrayed and denounced the "Iranian threat" in the darkest and most menacing of terms. ${ }^{59}$

Parsi's groundbreaking work incorporates much of this previous research while updating, and occasionally undermining prior conclusions with new information. Parsi argues that the majority of the literature on the Israeli-Iranian relationship overemphasizes ideological factors:

58. David Menashri, "The Jews of Iran” Between the Shah and Khomeini,” in AntiSemitism in Times of Crisis, ed. Sander L. Gilman and Steven T. Katz, (New York and London: New York University Press), 354-355.

59. David Menashri, “The Pahlavi Monarchy and the Islamic Revolution, in Esther's Children: A Portrait of Iranian Jews, ed. Houman Sarshar (Beverly Hills: Center for Iranian Jewish Oral History, 2002), 395. 
On one side was Israel, portrayed as a democracy in a region beset by authoritarianism and an eastern outpost of Enlightenment rationalism. On the other side was the Islamic Republic of Iran, depicted as a hidebound clerical regime whose rejection of the West and aspiration to speak for all Muslims everywhere were symbolized by its refusal to recognize Israel's right to exist. The Israeli-Iranian confrontation is far more complex than this ideology-based understanding would indicate, however. ${ }^{60}$

Parsi emphasizes the importance of strategic competition as the primary factor shaping the dynamics of Israeli-Iranian relations. Dismissing, and perhaps even caricaturing, the notion that ideas shape interests as much as interests shape ideas, Parsi finds "ideology" to be of little explanatory value, since it is only a mask for the strategic interests being pursued by both state actors. Many of the examples he offers of “ideology-focused” analyses focus almost exclusively on the attention paid to the Iranian side of the equation, ignoring the role that religious factors and cultural historiography play in the conceptualization and articulation of Israeli foreign policy.

The literature exploring the political role of religion within global politics in general, and focused upon either Israel or Iran in particular, have been dominated by studies of elite perceptions, interest-group bargaining, and institutional factors that lend themselves to positivist analysis. Jeff Haynes’ Religion in Global Politics, for example, devotes most of its attention to the development and relative success of religious parties as a measure of the salience of religious factors, maintaining a rationalist focus on power relationships relative to the state. ${ }^{61}$ The distinct challenges posed by religious paradigms, rather than parties, elude the conventions of "rationalist" analysis and therefore have

54. Trita Parsi, "Under the Veil of Ideology: The Israeli-Iranian Strategic Rivalry.” Middle East Report, June 9, 2006.

61. Jeff Haynes, Religion in Global Politics (London: Longman, 1998). 
ttracted little scholarly attention. Yet, I argue, they represent a crucial aspect of IsraelIranian relations. This study goes beyond Realism to explore the dynamics of the cultural and religious underpinnings of the "clash of narratives" that shape the dynamics of confrontation between Israel and Iran.

\section{Significance of Research}

Israelis are fond of quoting Henry Kissinger, a consummate Realist, who ruefully observed in 1975 that "Israel has no foreign policy, only domestic politics." In the past decade, and perhaps since the death of Khomeini, this observation has become increasingly true of Iran as well. Religion plays a plays a significant and a defining in role in domestic politics in both Israel and Iran.

My study approaches Israeli and Iranian foreign policy with an eye to their respective "unrealism.” Raymond Cohen calls attention to what he considers some of the most effective aspects of Israeli foreign policy, which contradict the tenets of pragmatism. "To rehabilitate a shattered people and build a state required hefty doses of ideological romanticism, heroic mythology, benign illusion, and rhetorical hyperbole--in short, what we call 'unrealism.”,62 This balancing of realism and "unrealism,” according to Cohen, has made Israeli foreign policy "unique.”

In a somewhat different sense, Rouhollah Ramazani also sees “unrealism” as a longstanding characteristic of Iranian foreign policy—the pursuit of political objectives that were beyond Iran's capability to achieve. Until the late nineteenth century, this

62. R. Cohen, “Israel’s Starry- Eyed Foreign Policy.” 
“chronic unrealism" of Iran’s rulers and diplomats was "rooted in ignorance, superstition, lack of experience, and other factors.” During the period of the Constitutional Revolution, the unrealism of the crafters of Iran's first constitution was that they chose political objectives that were beyond their means, not out of ignorance or superstition, but out of disregard for the internal and external context in which they uncompromisingly sought national independence. ${ }^{63}$

These two examples of unrealism are mirror images of one another, rather than contradictory. In the Israeli case, Theodor Herzl's dictum, "If you will it, it is no dream," called for pursuing objectives clearly beyond capability, implying that sheer will or desire to attain a political goal is not only a necessary but may even be sufficient condition for its attainment.

Profoundly unconventional, very unrealist assumptions also drive Israel's foreign relations. At critical moments in the past, when practical realism would have counselled immobility, caution, and even submission, Zionist and Israeli leaders made a Kierkegaardian leap of faith, basing fateful decisions on will, intuition, and what comes down to religious belief. Unrealism is understood as the conviction of a community that it has a certain destiny, and that seeking this destiny requires a dismissal of conventional odds and a willingness to take risks to reach historical goals. ${ }^{64}$

Ramazani asserts that what defeated the Iranian constitutionalists was their conviction that they could transcend the "internal and external context." Following the same logic, what favored the unrealism of the Zionist movement and made its dream of Jewish statehood possible was a favorable external context of political expansionism-

63. R. K. Ramazani, The Foreign Policy of Iran 1500-1941: A Developing Nation in World Affairs (Charlottesville: University of Virginia, 1966), 112. 
buttressed by Protestant religious evangelism. Throughout the latter half of the $19^{\text {th }}$ century, Britain, France and Russia were vying for maximum control over the territories of the deteriorating Ottoman Empire. The Balfour Declaration's favorable view of the creation of a Jewish national home in Palestine (there was no mention of a state) under a British mandate served British interests in preserving its hegemony over the region between the Nile and the Euphrates and over the Suez Canal in a way that the aspirations of Iranian constitutionalists did not. Furthermore, it complemented, and to a great extent, justified, these aspirations in religious terms.

Where the research presented here differs from, and complements, rationalist approaches to the relations between Israel and Iran is its focus on religious and cultural factors, and not on military and material cooperation or conflict, that have shaped the "internal and external context" in which Israel and Iran have sought to achieve their objectives. The Balfour Declaration favoring a Jewish homeland in Palestine, under a British mandate that would be recognized by the League of Nations, reflected a religious world view that animated British foreign policy during the nineteenth and early twentieth century. Its motivation was "Biblical rather than imperial:" according to Barbara Tuchman: "If the Biblical culture of England can be said to have any meaning in England's redemption of Palestine from the rule of Islam, it may be epitomized in Balfour.” Although he may have been a skeptic and philosophical pessimist, Lord Balfour was "strongly infused, like the Evangelicals and the Puritans, with the Hebraism

64. R. Cohen, “Israel’s Starry-Eyed Foreign Policy.” 
of the Bible. ${ }^{65}$ Realizing the enormous power that the Bible had in mobilizing support for a Jewish state gave the architects of Israeli statehood and Israeli political leaders an incentive for justifying the creation of the state, and its policies, in terms of the fulfillment of biblical prophecy.

In choosing to study the cultural sources of Israeli and Iranian foreign policy, and the responses of the "great powers" to them, from a comparative religious perspective, this research breaks new ground. This study takes as its starting point the thesis that Israel and Iran are two states in the Middle East where religious symbols, values and practices play a contentious and contested role in shaping national identity, domestic politics, and foreign policy. In both, there is a vocal and politically active of sector of society that is frequently labeled or characterized as "fundamentalist" by outsiders, but sees its own "belief based leadership" as the most authentic expression of the values of the nation; another that contends that religious values, properly understood, are compatible with modernity; and another that advocates, to a greater or lesser extent, the separation of religion from politics, opposed in theory and/or practice to the interference of government and religion in one another's realm of authority and institutions, and to the imposition of religious dictates by the state.

Neither contesting nor denying pragmatic, strategic, or structural explanations for the Israeli-Iranian geopolitical relationship before or since the Islamic Revolution in 1979, the goal of this study is to identify, elucidate, and interpret some unexplored dimensions of Israeli-Iranian relations, integrating religious historiography and social

65. Tuchman, 75. 
history into the framework of the study of global politics. Such an approach represents a challenge to the largely realist and positivist conventions of International Relations.

Building upon Yael Zerubavel's conceptualization of "master commemorative narratives," I show how Israel's "master commemorative narrative” of exile, return and redemption draws heavily upon the language and concepts of the Hebrew Bible. Situated within a historiographic narrative paradigm of covenantal patrimony, exile and return, the overwhelming majority of even the most secularized Israelis asserts and accepts the modern state's historical and geographic continuity with the biblical "promised land." So do many western Christian millenarians, particular dispensationalist Protestant Evangelicals, who were in great measure responsible for generating British and American sympathy and public support for Zionist aspirations, parallel to strategic considerations. As Timothy Weber points out, "Even before organized Zionism, dispensationalists advocated a Jewish state in the Middle East. For some time, they were more eager to see a restored Israel than most Jews.” 66

Extending this conceptual framework to Iran, I conceptualize Iran's “master commemorative narrative” as drawing upon varied Iranian religious traditions and motifs that express Iranian suspicion of foreign invasion, encroachment and interference. From the Shahnameh - the ancient epic that recounts the exploits of ancient heroes of ancient Iran— to contemporary exhortations delivered by religious and political leaders during

66. Timothy P. Weber. On the Road to Armageddon: How Evangelicals Became Israel's Best Friend (Grand Rapids: Baker Academic, 2004), 16. 
Friday prayers exalting the martyrs of the past and present, the underlying theme of Iran's "master commemorative narrative" is the ever-present danger of satanic foreign powers seeking to dominate, subjugate and exploit Iran, and glorifies the heroes who resist them.

This study thus complements rationalist approaches to Israeli-Iranian relations by focusing on specific components of cultural and religious historiography, and discursive practices that draw upon them. Evaluating them on their own terms makes it possible to see more clearly the uses that various ideological positions may make of them. In contrast to "political culture" approaches that treat political culture as static, this study focuses on the dynamics of the reinterpretation of cultural motifs, images and artifacts in both Israel and Iran.

The uniqueness of this study is twofold. On the one hand, it approaches the vociferous mutual hostility between Israel and Iran as the product of two historiographic traditions that have written each other off. I call these "the Persian problem in Jewish historiography" and "the Jewish problem in Shi ‘ite historiography.” Judaism’s "Persian problem" is the overwhelming historical evidence that the three primary texts of Judaism - the Hebrew Bible, the prayer book (siddur) and the Talmud-were all produced or redacted under Persian rule and/or a Persian-influenced environment. Jewish religious historiography compressed the entire period of Achaemenid rule over Judea to as few as 39 years, in order to validate the prophecies in the biblical Book of Daniel.

Academic Jewish historians have marginalized the Jewish-Persian connection by referring to the descendants of the exilic community that chose not to return to Judea when offered the opportunity to do so as the "Jews of Babylonia." This designation 
ignores, or at least obscures, the historical fact that, from the time of its conquest by Cyrus in (539 BCE) until the Islamic conquest (650 BCE)—over a thousand years— "Babylonia" was an integral part of the Persian Empire,. With the exception of the relatively brief period between Alexander's conquest of Babylon in 331 BCE and the Parthian conquest of most of the Achaemenid Empire by 141 BCE, when Persia was under Seleucid rule, the Jews of Babylonia were, in point of fact, living in Iran.

Focusing on the ways in which religious and cultural factors influence both Israeli and Iranian foreign policy discourse from comparative perspective, this research views religion not as a monolithic ideology in and of itself, but as the source and repository of images from which various ideological positions, competing narratives and contending discourses may draw in the construction and support of ideologies. Israeli and Iranian leaders draw upon "lions and roses"-my term for culturally embedded images, motifs, and myths that can absorb and evoke a multiplicity of meanings, associations, and implications, that serve as framework for depicting and understanding the discourse about contemporary political issues--that not only challenge one another, but which use each other as a mirror to reflect domestic debates over the role of religion in state and society.

\section{Chapter Outline}

In this chapter, I have outlined a broad basis for a comparative approach to Israeli and Iranian culture and identity. Chapter Two of this study examines a variety of texts and traditions concerning the first Achaemenid Persian king, Cyrus II. An iconic figure in Babylonian, Greek, Jewish, and Iranian historiography, Cyrus was appropriated by nineteenth century European and American end-time dispensationalist Christian 
evangelism that, in league with imperial ambition, sought the return of the Jews to Palestine as a precursor to the Second Coming. It also explores the $20^{\text {th }}$ century political contexts in which Cyrus has been invoked. As Yaacov Shavit points out, Cyrus is a fascinating case study that illustrates how and when available knowledge of a historic fact becomes institutionalized in active collective memory—or does not. ${ }^{67}$

Chapter Three provides an overview and analysis of the religious and cultural sources of Israeli and Iranian foreign policy, viewed through the optic of "master commemorative narrative.” Israel's master commemorative narrative draws heavily upon the Hebrew Bible, within a historiographic paradigm of covenantal patrimony, exile, and return. Iranian "master commemorative narrative" is predicated on a paradigm of invasion, injustice, and resistance, reified in imagery from Iran’s pre-Islamic past as well as Shi'ite martyrology.

The "Haman factor" provides a biblical personage who overshadows and overwrites Cyrus, as well as a crucial link the archetypal Israelite enemy Amalek with the Holocaust, which became a central motif of Israeli foreign policy discourse when the Likud gained power in 1977. The Auschwitz paradigm views the Jewish people as the perpetual victims of history. Iranian use of imagery related to the martyrdom of Imam Husayn at Karbala depicts the Iranian people in the role of the Shi'ite martyr in its confrontations with its enemies. This chapter discusses the clash of these narratives.

Chapter Four consists of a study of "master commemorative narratives" in practice, case study that illustrates and illuminates the interconnection of two defining

67. Shavit, "Cyrus King of Persia,” 54. 
issues in which two primary arenas in which Israeli and Iranian interests come into conflict. One is the Palestinian issue. From the perspective of Israeli commemorative narrative that emphasizes the continuity between the Israelite polity depicted in the Hebrew Bible and the modern State of Israel, Jews are exiles returning home, and Palestinian Arabs, are the latest incarnation of the "peoples of the land" which they have Divine mandate, as well as the strategic need, to dispossess. Iranian leaders depict the Palestinians as, like themselves, victims of invasion and injustice.

The second theme is nuclear technology. Israelis and Iranians both challenge the non-proliferation norm through different strategies of defiance, based upon their "master commemorative narratives.” Israel's nuclear strategy has been referred to as its "Samson option,” named for the biblical hero who uses his God-given strength to destroy the Philistine enemies of the ancient Israelites, although he himself perishes in bringing about their destruction (Judges. 13:1-6). For Iranians, acquiring nuclear technology has taken on enormous symbolic significance in the face of U.S. and Israeli opposition.

A broad spectrum of Iranian society views nuclear capability as Iran's opportunity not only to once again be recognized as a great nation, and a major regional player, but, in keeping with its own "master commemorative narrative" to immunize itself against foreign invasion and domination. Iranian leaders and clerics have repeatedly declared that the building or use of nuclear weapons is haram, forbidden by Islam, while insisting on Iran's right, as a signatory of the NPT, to develop nuclear technology for peaceful purposes. The attempt by foreign powers, goaded by Israel, to force Iran to "voluntarily" desist from the nuclear research which it is entitled to pursue 
as a signatory of the Nuclear Non-Proliferation Treaty (NPT) is viewed as keeping Iran dependent and vulnerable to attack and invasion.

In the post-9/11 effort to build a "coalition of the willing” against Afghanistan, Israel and Iran competed with one another for opportunities to attain their own respective foreign policy goals, the major themes in their "master commemorative narratives" are readily discernible in the rhetoric directed against one another and the U.S.

The fifth and concluding chapter deals with the "clash of narratives” between Auschwitz and Ashura, which are mirror images of one another. The negative images that Israelis and Iranians have of each other reflect the dangers most feared within their respective narratives. For Iran, Israel is not only an intruder into the Middle East, placed there and protected by foreign powers; it also is an example of what happens when foreign powers are permitted to determine, undermine, or usurp national priorities and responsibility to God. For secular Israelis, Iran is a case study of the danger of its own religious parties gaining political power. In the press and in popular culture, comparisons between the rabbinate to Israel's ayatollahs resonate profoundly.

My conclusions also examine why Israeli and Iranian foreign policy discourses elicit diametrically opposite responses from the U.S. While the pursuit of geo-strategic interests explains a great deal about state behavior, many political scientists and security analysts have questioned why U.S. interests would not be better served by alliances with states in the Muslim world. I suggest that Israel's discursive competitive advantage derives in part from the underpinnings of Americans' own restorationist bias that provides a religious and cultural backdrop to the triangulation of the U.S., Israel and Iran that is largely ignored. To the extent to which the contemporary State of Israel is viewed 
as a reincarnation of the ancient biblical "promised land" and the return of the Jewish people to it as a fulfillment of Jewish and Christian prophecy, there is a sympathy and acceptance of Israeli foreign policy as an aspect and extension of American "faith based foreign policy.” Furthermore, in seeing itself as part of an ancient Greco-Roman historiography that serves as the underpinning the concept of "western civilization,” the U.S. has absorbed and advocates a largely negative view of Iran.

Finally, the conclusions of this study suggest some ways in which "master commemorative narratives" and the insights they provide into some of the religious and cultural factors can enrich the understanding of Israeli and Iranian foreign policy discourse. They reveal not only how Israelis and Iranians depict each other, but how they view themselves. I argue that greater understanding of "master commemorative narratives” and the religious, historical, and cultural components of foreign policy might enrich the fields of International Relations and Political Science. I explain what the practical value might be for policy analysts and diplomats of adding to their understanding of religious and cultural concepts that are embedded in Israeli and Iranian foreign policy discourse.

\section{On the Title "Lions and Roses"}

This study takes as its starting point the proposition that Israel and Iran share a common cultural heritage that, for both religious and geostrategic reasons, both would prefer to ignore or deny. Three of the most formative events in Jewish religious history - the canonization of the Hebrew Bible, the compilation of the Jewish prayer 
book and the redaction of the Babylonian Talmud—took place within a Persian cultural and religious milieu. Persian words found in the Bible are still in use today. ${ }^{68}$

Cyrus the Great set in motion the return of the Judeans who had been exiled to Babylon to return to Jerusalem if they wished, and allowed them to rebuild their Temple. Darius actively facilitated the Temple’s reconstruction and permitted the imposition of numerous laws and regulations that would constitute the legal and ritual framework of what would become halakha. ${ }^{69}$ It should not be surprising that these two exceptionalist cultures-Iranian and Jewish—not only share a few flashpoints in their history, but a cultural cache of myths and symbols that, under current circumstances, they might prefer to forget. While the symbolic content and use of these motifs have changed over time, they retain both their multivocal emotive content.

There are several words for "lion” in Hebrew, the most general being ari or aryeh. In the Bible, the patriarch Jacob blesses his son Judah with supremacy over his brothers as well as his enemies, referring to him both as a lion cub (gur aryeh) and as a crouching

68. Words of distinctly Persian origin that are found in the later books of the Hebrew Bible survive in modern Hebrew include dat (law, religion), raz (secret), pitgam (edict or epigrammatic saying) and gizbar (treasurer). William Chomsky, Hebrew: The Eternal Language (Philadelphia: Jewish Publication Society, 1957), 168-169.

69. The precise level of involvement of the Achaemenid rulers with the evolving constitutive religious and legal codification imposed in Judea under Ezra is a matter of contention among scholars. That written and oral traditions took the form of a religious and legal code during the Persian period of rule over Yehud is much less controversial. See the various critiques of Peter Frei's theory of imperial authorization-i.e. that the Torah was accepted as law in Judea/Yehud because Ezra was authorized by the Persian king to impose it-- in James W. Watt, ed., Persia and Torah: The Theory of Imperial Authorization of the Pentateuch (Atlanta: Society of Biblical Literature, 2001). For a etailed overview of arguments for Iranian influences in Jewish sacred text, see David Winston, "The Iranian Component in the Bible, Apocrypha and Qumran,” History of Religions 5, no. 2 (Winter 1966), 183-216. 
lion (lavi) that no one dares to arouse (Gen. 49:9). The Midianite prophet Balaam compares the Israelite people to a lion that will arise and consume its prey ((Num. 23:24). The tribes of Dan and Gad are also compared to lions in Moses' blessing of the Israelites before his death (Deut. 33:20; 33:23). Lions attack humans as agents of God's justice (I Kings 13:24; 30:36; II Kings 17:25), but heroes such as Samson (Judges 14:5) and David (II Sam. 23:20) fought lions barehanded, and prevailed because the Divine Spirit rests upon them. In the prophetic books of the Bible, the roar of a lion variously represents the threat of an approaching enemy (Isa. 5:29; Jer. 4:7), corrupt rulers and false prophets (Zeph. 3:3; Eze. 22:25) and the voice of God (Jer. 25:30; Joel 4:16; Amos 1:2, 3:8).

In Persian tradition the identification of the head of state with the lion goes back at least two and a half millennia. Two large terra cotta lions have been excavated that guarded the entrance to a temple in Susa. ${ }^{70}$ The statue of Darius discovered at Susa in 1972, and every other royal depiction from Darius to Artaxerxes I, show the Persian king in a robe decorated with a row of striding lions. ${ }^{71}$ Lion hunts were the special prerogative of the Persian king. ${ }^{72}$ Scenes of royal-hunter kings found on Achaemenid seals show kings in confrontations with lions, although clearly not intended to depict them with photographic realism. ${ }^{73}$ In Persian reliefs found at Persepolis, the royal figure

70. H.G. Spearling, "Susa: the Eternal City of the East". Wonders of the Past. Edited by Sir J. A. Hammerton. v.2, (New York: Wise and Co., 1937), 700.

71. Briant, 216

72. The story of Megbyzus, as told by Csetius, illustrates the Persian court protocol that reserved the killing of lions - at least the right to cast the first spear- to the monarch. Ctesias 40, quoted by Briant, 231-232.

73. Briant, 232. 
is shown fighting real or mythical animals, including lions and monsters with horned lions heads, usually grasping the mane with his left hand and inserting his sword with his right, sometimes smothering the lion with his left arm while holding a lotus flower in his left hand and his sword in his right. ${ }^{74}$

Ancient seals and rings, and royal inscriptions from the time of Artaxerxes II, show the king reaching out to the war and water goddess Anahita ${ }^{75}$ while she stands on a lion, a baton in her left hand and a flower in her right. ${ }^{76}$ Traditions about Anahita and water came to be identified with Fatima, daughter of Mohammed, while her husband, Ali ibn Abi Talib, was associated with the lion and became known as the "lion of Allah."77 Water reservoirs in Iran had stone lions outside them, and traditional bathhouses had water faucets in the shape of lions' heads. ${ }^{78}$

74. Briant, 218.

75. Anahita was also the patroness of women, and the goddess of both fertility and waters of rivers, lakes and childbirth. After the Persian conquest of Babylon, she became increasingly identified with Ishtar. She also is depicted as the consort of Mithra. Temples in her honor were built in Susa, Ecbatana and Babylon during the reign of king Artaxerxes (436-358 BCE).

76. Briant, 253-254.

77. Massoume Price, “Distinguished Women, Past and Present: Fatima is Fatima,” (From a lecture, CIRA, University of Toronto, 2001). Iran Chamber Society website, 24 April 2006. http://www.iranchamber.com/podium/culture/020915_fatima_fatima.php (accessed April 26, 2006). Price notes that a rarely quoted story from traditional Persian literature draws an analogy between Anahita, who bathes in a river and emerges pregnant with the Messiah who will save the world, and the Prophet's daughter Fatima, who bathes in a river and comes out pregnant with Imam Hussein.

78. This perhaps indicated that the lions were the guardians of the water, which was both in limited supply and had to be protected from pollution. Parviz Tanavoli, Lion Rugs: The Lion in the Art and Culture of Iran (n.p.: Transbooks, 1985) points out that the Farsi word shir means both lion and the water spout (14-15). On lion motifs in Persian carpets, also see Peter Anderson, 
According to the epic poet Ferdowsi, the symbol of the lion and the sun (Shir-oKhorshid) was used by Rostam, one of the heroes of his Shahnameh (written 1010 CE), which is replete with lion imagery. ${ }^{79}$ Lion motifs are prominent in Iranian decorative arts, and are particularly evident in the immense number and variety of lion rugs (gabbeh-ye shiri). ${ }^{80}$ Since 1031, lions in various postures have been a prominent feature of Iranian flags. Sultan Mahmoud Ghazavi, the first Iranian ruler to adopt the lion as an Iranian national symbol, was said to have been by the inscription of a lion on the walls of Persepolis and by the excavation of an archaeological plate imprinted with a lion in Ray. ${ }^{81}$ The Safavid dynasty, which adopted Twelver Shi'ism as the Iranian state religion after its establishment in 1501, made the lion the official emblem of the state, emphasizing the connection with Ali, to whom Shi‘ism traces its origin. The Iranian Constitution of 1906 declared the official flag of Iran to be a green, white, and red tricolor with the lion and the sun. ${ }^{82}$ However, notwithstanding its association with Ali, the lion was removed from the Iranian flag after the Islamic Revolution in 1979.

“The Chelsea Carpet,” Oriental Rug Review. http://www.rugreview.com/orr/chel.htm (accessed April 26, 2006).

79. Abolqasem Ferdowsi, Shahnameh: The Persian Book of Kings, transl. Dick Davis (New York et al: Penguin Books, 2007).

80. Peter Anderson, “The Chelsea Carpet.”

81. For a full discussion of Iranian flags and the variety of images of lions on them, Davood N. Rahni, “The Iranian Flag”: A Brief History.” Persian Mirror online. http://www.persianmirror.com/culture/history/PersianFlag.cfm (accessed April 26, 2006).

82. Rahni, “The Iranian Flag.” 
Roses are also a shared symbol, frequently found in ancient Persian art and architecture. In both Iranian and Jewish tradition, the righteous, particularly martyrs, are compared to roses, the most precious of flowers. ${ }^{83}$ Idealized portraits of the Achaemenid kings show rosettes on their robes. The Susa palace of Darius the Great (522-486 BCE) was decorated with rosettes. ${ }^{84}$ Shoshan, a Hebrew word for flower interchangeably translated as "rose" or "lily," 85 is etymologically derived from Shushan, the Hebrew name for the Persian capital city of Susa. ${ }^{86}$ According to the Mishna (Middot 1:3) and the Babylonian Talmud (Menachot 98a), the eastern gate of the Second Temple in Jerusalem, reconstructed during the reign of Darius I, was known as the "Shushan gate" and was distinguished by its sculptured mural of the Susa palace. There, Yehudim bowed in worship of "the king of the king of kings" (melech malechi hamelachim). Psalms 45, 69, and 80 are designated in the Hebrew Bible as psalms of the shoshanim, and Psalm 60 refers to the shoshan edut, the "rose of witness." ${ }^{87}$ The shoshan was prominently

83. Morris Jastrow, Dictionary of the Targumim the Talmud Babli and Yerushalmi, and the Midrashic Literature (London: Luzac and New York: G.P. Putnam, 1903) v. 2, 1543-44.

84. Jona Lendering, "History of Iran: Susa , Capital of Elam.” Iran Chamber Society website, http://www.iranchamber.com/history/susa/susa.php (accessed April 28, 2006).

85. So as to avoid the inconsistency among various translators in translating shoshan as "rose" and as "lily", and to emphasize the connection of shoshan with Shushan (Susa), I refer to shoshan/shoshanim in these citations, irrespective of how the individual authors and translators of the various works cited here translate shoshan.

86. Jastrow, 1543.

87. Some biblical commentators claim that "shoshanim" in this case were rosette-shaped musical instruments used in the Temple service, while others consider the significance of the designation to be unclear. The meaning of shoshan edut ("rose of witness") is particularly obscure. 
featured on coins from the era of the early Hasmonean kings John Hyrcanus and Alexander Jannaeus. ${ }^{88}$

Karaism, a heterodox anti-Talmudic movement within Judaism that originated in the seventh century, reached its fullest development in Persia during the ninth through eleventh centuries before spreading into Eastern Europe, the Balkans, and Spain. Among them were avelei tzion (Mourners of Zion), many of whom made their way to Palestine during the Middle Ages and settled there. A tenth and eleventh century community in Jerusalem, founded by the Persian Karaite Daniel al Kumisi (late $9^{\text {th }}$-early $10^{\text {th }}$ century), called themselves the congregation of the Shoshanim. The Shoshanim based their liturgy on the Bible and utilized a prognostic exegetical technique like that of the pesharim of the Dead Sea sect found at Qumran. They read the prophecies in the latter chapters of Isaiah, which most scholars attribute to a second or third Isaiah of the early Achaemenid period, and the metaphor of the "rose among the thorns" (2:1-2) in the allegorical poetry of the Song of Songs (Canticles), as referring to their own community. ${ }^{89}$ A commentary to Psalm 80:1 by Japhet ben Eli (late $10^{\text {th }}$ century), the foremost exegete of the Jerusalem Karaite community, explains the significance of the Psalms of the Shoshanim to the sect:

“...we have already mentioned to whom the "Shoshanim refer... We have stated that these Shoshanim are the people who sprout up amidst thorns...They

88. Paul Romanoff, “Jewish Symbols on Ancient Jewish Coins, (Continued)” Jewish Quarterly Review, New Series. XXXIV (1943), 301.

89. Daniel Frank, "The Shoshanim of Tenth-Century Jerusalem: Karaite Exegesis, Prayer, and Communal Identity,” in The Jews of Medieval Islam: Community, Society, and Identity: Proceedings of an International Conference Held by the Institute of Jewish Studies, University College London, 1992. Etudes sur le judaisme médiéval, t. 16, (ed. Daniel Frank; Leiden: E.J. Brill, 1995), 200-201. (Frank translates shoshan as "lily.”) 
are mentioned in three Psalms, "My heart overflows," "Save me O God (Psalms 45 and 69), and here in order to inform us that the Psalm is their prayer."90

This study draws upon the images of lions and roses in Jewish and Iranian tradition as emblematic of the rich variety of ways in which motifs and myths from sacred texts, interpretative commentaries, and legendary traditions, old and new, are appropriated into, or excluded from, into competing historiographic narratives, cultural practices, rituals and foreign policy discourse in the Jewish State of Israel and the Islamic Republic of Iran. That there has ever been any sharing of these motifs and myths has practically been banished from Jewish “collective memory” for well over two millennia. It has never become part of the State of Israel's “master commemorative narrative” and has probably never been recognized within Iranian historiography. References to shared images and practices are rare in Shi'ite or nationalist discourse as well. While the visual images retain outwardly recognizable forms, the understanding of their meanings, significance and their discursive utility are continually evolving, and are nonetheless are available to both.

90. Frank, 223-224. 


\section{CHAPTER II}

\section{USES OF THE PAST: TEXTS AND CONTEXTS}

\section{Cyrus: the Man and the Myth}

Few men personify the intertwining of history and myth more quintessentially than Cyrus II of Persia (ruled 557-529 BCE), best known today by the moniker "Cyrus the Great." His oldest known genealogy identifies him as the son of Cambyses (Kambujiya), grandson of Cyrus, a descendant of Teispes (Chishpish), and thus legitimate heir to the dynastic succession of "Great Kings of Anshan."91 Archaeological evidence supports the identification of Anshan with Persis, the Greek name for the high country region of the Marv Dasht plain in Fars. ${ }^{92}$

By the time of his death, Cyrus' kingdom is said to have been the largest the ancient world had yet known, extending to the major coastal cities of Asia Minor along the Black Sea, absorbing the Chaldean empire, most of Central Asia, and, stretching eastward toward India, and westward to Cyprus and the border of Egypt. ${ }^{93}$ It extended "beyond the river" to where the trade routes of Asia, North Africa, the Persian Gulf and

91. James B. Pritchard, ed. Ancient Near Eastern Texts Relating to the Old Testament, 3rd ed. (Princeton: Princeton University Press,1969), 315. For purposes of standardization and simplicity of electronic reproduction, English spelling and Persian transliterations here follow Frye's genealogy of the Achaemenids,” in The Heritage of Ancient Persia, Appendix 1, 318.

92. Pierre Briant, From Cyrus to Alexander: a History of the Persian Empire, transl. Peter T. Daniels (Winona Lake, IN: Eisenbrauns, 2002), 7.

93. Muhammad A. Dandamaev and Vladimir G. Lukonin, The Culture and Social Institutions of Ancient Iran (Cambridge, New York et al.: Cambridge University, 1989), 90-91. According to the Cyropaedia of Xenophon, "On the east it was bounded by the Red Sea [according to the translation of Henry Graham Dakyns; other translators render the eastern boundary as the Indian Ocean], on the north by the Euxine [Black Sea], on the west by Cyprus and Egypt, and on the south by Ethiopia” (8:1). 
the Mediterranean Sea converged. The Trans-Euphrates province included Yehud (Yehuda in Hebrew, anglicized into Judah or Judea), a remnant of the region that the ancient Israelites knew as "the land of Canaan" that the Romans, and later, the British, would call "Palestine.",94

\section{Ancient Babylonian Sources}

Several Babylonian artifacts attest to Cyrus’ historicity, although they provide minimal biographical data. The reign of Cyrus appears on the Uruk King List, a damaged chronological inscription on a cuneiform tablet listing the kings between the twenty-one year reign of Kandalanu (ruled 648-627 BCE) through the twenty year reign

of Seleucus II, between that of Nabonidus and Cambyses, but the length of both reigns is missing from the tablet. ${ }^{95}$

Another cuneiform tablet known as the Nabonidus Chronicle summarizes the major events during each year between the accessions of Nabonidus to the Babylonian throne (c. 556 BCE) until the 530s BCE. In the sixth year of Nabonidus' reign, King Ishtumegu (Astyages) marched his armies against Cyrus, the king of Anshan. Ishtumegu's troops revolted and delivered him to Cyrus. Beginning in the seventh year of his reign, Nabonidus spent the first of ten years of his reign in Arabia, where he established a based at the Tema oasis on the caravan routes, and leaving his son Bel-shar-

94. For most of the nearly two millennia between Roman and British dominance, including the centuries of Ottoman rule, this region was part of Coelo-Syria, as it had been during Ptolomaic and Seleucid times.

95. Pritchard, 566. 
usur (Belshazzar of the Hebrew Bible) in charge of administering the empire. Because of Nabonidus' absence, the annual spring festival rituals that required the king's presence could not be held. In the ninth year, the king's mother died, and Cyrus, now called the king of Persia, marched against Lydia, killing its king. ${ }^{96}$

In the seventeenth year, according to the Chronicle, Nabonidus was back in Babylon, and the new year rituals were able to take place in their entirety. However, in the month of Tashritu, the Babylonian army was defeated by the Persian army east of the Tigris River at Opis. The inhabitants of Akkad took the opportunity to revolt, whereupon Nabonidus massacred them. The city of Sippar then surrendered to Cyrus without a battle, and Nabonidus fled. Three days later, Cyrus entered Babylon, again with no resistance. Green twigs were spread in front of him, peace (sulumu) was imposed on the city, and Nabonidus was arrested. Cyrus sent his greetings to all of the Babylonian empire, and installed his own administrators. ${ }^{97}$

The "Cyrus Cylinder," a ten inch barrel-shaped clay charter placed in the foundations of the city wall soon after Cyrus' conquest of Babylon in 539 BCE, recounts Cyrus' benevolent treatment of the peoples he conquered. The Babylonian god Marduk, who had searched for a righteous ruler to lead the annual procession of Babylon's gods, chose Cyrus because of his good deeds and upright heart. When Cyrus entered Babylon, it was without a battle. Sparing its inhabitants any calamity, he allowed them to return to

96. Pritchard, 305-306.

97. Pritchard, 306-307. 
their homes with their gods, restoring respect for the local Babylonian deities, their shrines and their priesthood:

I am Cyrus, King of the world, great king, legitimate king, king of Babylon, king of the land of Sumer and Akkad, king of the four rims (of the earth), son of Cambyses, great king, king of Anshan, grandson of Cyrus, great king, king of Anshan, descendant of Teispes, great king, king of Anshan, of a family (which) always (exercised) kingship; whose rule Bel and Nebo love, whom they want as a king to please their hearts.

When I entered Babylon as a friend and (when) I established the seat of the government in the palace of the ruler under jubilation and rejoicing, Marduk, the great lord, [induced] the magnanimous inhabitants of Babylon [to love me] and I was daily endeavoring to worship him. My numerous troops walked around in Babylon in peace, I did not allow anybody to terrorize (any place) of the [country of Sumer] and Akkad. I strove for peace in Babylon and in all his (other) sacred cities. As to the inhabitants of Babylon [who] against the will of the gods [had/were...I abolished] the corvee (lit.: yoke) which was against their (social) standing. I brought relief to their dilapidated housing, putting (thus) an end to their (main) complaints. Marduk, the great Lord, was well pleased with my deeds, and send friendly blessings to myself, Cyrus, the king who worships him, to Cambyses, my son, the offspring of [my] loins, as well as to all my troops, and we all [praised] his great [godhead] joyously, standing before him in peace... ${ }^{98}$

98. Pritchard, 315-16. Some translations found on websites append a spurious "translation" of a short Document B to the passage cited above. Particularly suspicious is the substitution of (Ahura) Mazda for Marduk in this version of the human rights charter reproduced by Shapour Suren-Pahlav, History of Iran: Cyrus Charter of Human Rights on the website of the Iran Chamber Society <http://www.iranchamber.com/history/cyrus/cyrus_charter.php> (to which I have made a few minor spelling and grammar corrections):

Now that I put the crown of kingdom of Iran, Babylon, and the nations of the four directions on the head with the help of (Ahura) Mazda, I announce that I will respect the traditions, customs and religions of the nations of my empire and never let any of my governors and subordinates look down on or insult them until I am alive. From now on, till (Ahura) Mazda grants me the kingdom favor, I will impose my monarchy on no nation. Each is free to accept it, and if any one of them rejects it, I resolve to never reign by war. As long as I am the king of Iran, Babylon, and the nations of the four directions, I will never let anyone oppress any others, and if it occurs, I will take his or her right back and penalize the oppressor. And as long as I am the monarch, I will never let anyone take possession of movable and landed properties of the others by force or without compensation. As long as I am alive, I prevent unpaid, forced labor. Today, I announce that everyone is free to choose a religion. People are free to live in all regions and take up a job provided that they never violate other's rights to prohibit exchanging men and women as slaves within their own ruling domains. .. 
The cylinder affirms that Cyrus treated Babylon well and maintained peace there, and that Babylonians prospered because of the wealth pouring into the economy from tribute.

In 1898, the German theologian Rudolf Kittel noticed a few of the similarities between Cyrus’s proclamation in the Babylonian cylinder and elements in chapters 40-48 of the biblical book of Isaiah, believed by scholars to have been authored by the "second Isaiah.” In both, the god calls Cyrus his friend, declares he has chosen Cyrus to do his will, and designates him as ruler. Kittel suggested that the two were dependent upon a general Babylonian court style. ${ }^{99}$ Morton Smith took Kittel’s observations even further, pointing out numerous details in the parallels than Kittel had not discussed: the god calling Cyrus "by name,” his taking Cyrus "by the hand” and subjecting numerous peoples to him, as well as both gods' delight in Cyrus because of his concern for justice. The second half of the Cyrus cylinder has no parallel in Isaiah, Smith observes. It recounts that Cyrus treated the Babylonians well, maintaining peace, and that the Babylonians were prospering because of the wealth pouring into the economy from tribute. Foreign peoples and their gods were being sent home. ${ }^{100}$

Smith suggests that neither the Babylonians nor the Judeans were actually deceived-“administration performance rarely lives up to campaign promises. ${ }^{101}$

99. R. Kittel, “Cyrus und Deuterojesaja.” Zeitschrift für die alttestamentliche Wissenschaft 18 (1898), 149ff, cited by Morton Smith in, "II Isaiah and the Persians," Journal of the American Oriental Society, 83:4, September-December 1963, 415.

100. Smith, "II Isaiah and the Persians,” 418.

101. Smith, "II Isaiah and the Persians," 418. 
Ironically, centuries later, when the Zoroastrian scribes turned to Babylonian sources to reconstruct their own historiography, Cyrus, like Darius and Xerxes, was not there, "since the first terminated the independence of their land, the second suppressed a revolution there, and the third quelled a rising and punished those concerned.” 102

\section{Classical Greece: “Inventing the Barbarian”}

The historians and playwrights of ancient Greece provide nearly all of what might be called "biographical" details about the life of Cyrus, as they were heard by Greek ears. Drawing exclusively upon oral history, Greek accounts of Cyrus are generously spiced with myth and legend, as well as a Hellenic hostility toward Greece's greatest rival, Persia. Pierre Briant cautions, "It is necessary, at each step, to distinguish the kernel of Achaemenid facts from the Greek interpretation—not always an easy task.”103 Hellenocentric views of Persia, written long after Cyrus' death, contributed to the invention and construction of a binary opposition between Greeks and "barbarians" from which Cyrus himself was largely, although not totally, exempt.

Edith Hall notes that the Greek term barbaros [barbarian], before the $5^{\text {th }}$ century BCE, meant "not speaking Greek," and was first applied to the peoples of the Achaemenid empire with whom the Greeks had contact, including Phoenicians,

102. A. Shapur Shahbazi, “The ‘Traditional Date of Zoroaster' Explained,” Bulletin of the School of Oriental and African Studies, University of London, 40, no. 1 (1977), 32.

103. Briant, 7-8. 
Egyptians, Thracians, and Phrygians as well as Persians and Medes. ${ }^{104}$ The term "barbarian” was first used pejoratively in the Persae of the Attican dramatist Aeschylus (525-456 BCE), a veteran of the battle of Marathon (490 BCE). It began to conceptualize the Greek conflict with Persia as "as a struggle of united and disciplined Greeks against alien violence.”105 Nonetheless, in The Persians, Aeschylus depicts Cyrus as blessed with a lucky destiny, and as a ruler who secured peace for his friends. As a ruler, he showed sound understanding, and because of this, "God did not hate him.”"106

Persian expansion into Asia Minor began with Cyrus’ campaigns into Lydia (547546 BCE) and Lydia's vassal, Ionia, after which, Stephen Hirsch emphasizes, the Asiatic Greek cities lived quietly under Persian rule for about half a century. During this period, "the Greeks of mainland Greece did not become entangled in the affairs of Asia Minor, nor did they cause Persia any trouble.»107 Cyrus had extended his empire through overland conquest. Only after Darius and Xerxes ventured into the Aegean through the projection of naval power did the Greeks become defensive and hostile, Hirsch argues, because the Greeks regarded mastery at sea as being a part of the Greek nomos, while the nomos of the Persians confined them to the land. "To the Greek mind, the Persians had

104. Edith Hall, Inventing the Barbarian: Greek Self-Definition Through Tragedy (Oxford, Clarendon Press, 1989), 9-11.

105. Hall, 58

106. Aeschylus, The Tragedies of Aeschylus, translated from the text of Blomfield (Oxford: Oxford University, 1827) 106.

107. Steven W. Hirsch, "Cyrus' Parable of the Fish: Sea Power in the Early Relations of Greece and Persia,” The Classical Journal, Vol. 81, No. 3 (February - March, 1986), 227. 
disrupted the natural order of the world by taking to the sea at the beginning of the fifth century." 108

It was during the period of Persian expansion into the Aegean, Hall notes, that a Greek identity began to take shape that subsumed, at least temporarily, archaic ethnic ties to the various Hellenic city-states, constructing a binary opposition between Greek and barbarian, Panhellenic and Persian:

The full significance of belonging to a wider Greek family was not to become apparent until most of the Greek-speaking communities came under threat from Persia; even then some were slower than others to recognize that they had any responsibility towards other Greeks, and quicker to abandon Panhellenism after the Persian wars. ${ }^{109}$

Herodotus (c.485-425 BCE), credited with being the inventor of historical writing, was a native of the Ionian city of Halicarnassus, on the southwestern coast of Asia Minor. As a vassal of Lydia, Ionia had submitted to Cyrus immediately after he had overcome Lydian resistance. Herodotus' single extant work, the Histories (also published under the title The Persian Wars), chronicles the decade of battles (490-479 BCE) between Greece and Persia during the reigns of Darius and Xerxes. Born half a century after the death of Cyrus and too young to have fought in the wars against the Persians, Herodotus recounts that many of the Greek city-states of Anatolia chose to make their peace with the conquering Persians. In others, however, most of the population set sail for various islands of the Aegean, leaving behind their empty cities to the Persians. In the background, he provides to the events leading up to the Greco-

108. Hirsch, 229.

109. Hall, 9. 
Persian wars, Herodotus provides much of what little "biographical" information there is about the life of Cyrus. Generally regarded as the most reliable of the Greek sources concerning the Achaemenid period, Herodotus nonetheless evidences a strong pro-Greek bias, while incorporating numerous and easily recognizable folkloric motifs into his account of Cyrus' life.

For example, Herodotus recounts that Cyrus' grandfather Astyages, son of Cyaxares, had dreams and visions which the Magi interpreted as portending that the son of his daughter, Mandane, and her husband, Cambyses, would be king over all of Asia. When Mandane gave birth to Cyrus, Astyages, fearing an eclipse of his own power and glory, ordered that the infant be abandoned and left to die. Nevertheless, Harpagus, a member of the royal household entrusted with killing Cyrus, gives him to a herdsman and his wife to raise him (I:108-113). ${ }^{110}$ When Cyrus was ten years old, Astyages’ suspicions were aroused, and the herdsman, under threat of torture, gave a full account of the circumstances under which the child had come to him. Hiding his anger at Harpagus,

110. Herodotus, Persian Wars I:107-121. The folkloric motif of an infant who the regnant monarch order to be abandoned or slain because of a prophecy that the child will supercede him in power or popularity is a well-known and widespread one in the ancient world. This account of Cyrus' birth has numerous parallels with that of the mythic Iranian Kay Khosrow in the Shahnameh, who is entrusted to shepherds to raise, in order to protect him from the Turanian king Afrasyab. The motif is a popular one in Greek heroic tradition, and the resemblances of it to the myths of Perseus and Oedipus are obvious. A variant of this motif is found in Exodus 1:15-2:-3 concerning Moses, which in turn is adapted and incorporated into Matthew's account (2:1-13) of the birth of Jesus. Herodotus mentions but rejects another version of Cyrus' origin: that he was exposed and left to die as a child and was nursed and raised by a dog (1:122). In Roman mythology the founders of Rome, Romulus and Remus, were abandoned by their uncle Amilius, who feared his claim to the throne was jeopardized by the birth of his older brother Numitor's grandsons, and were raised by a wolf. 
Astyages tricked Harpagus into eating the flesh of is own son at a banquet purportedly celebrating Cyrus' survival. Harpagus avenged the murder of his son by aiding Cyrus in leading a Persian revolt against the Medean empire when he reached maturity (I 120130).

Herodotus admits he is most interested in those conquests of Asia Minor that gave Cyrus the most trouble, and were therefore, from his perspective, the most interesting and worthy of inclusion (I:156-177) . According to Herodotus, Cyrus met his death in the twenty-ninth year of his reign, when he set out to add the northern Caspian kingdom of the Massegetae to his empire. Cyrus was slain in a fierce battle that largely wiped out his Persian army. Herodotus provides a lurid depiction of the Massegetae queen, Tomyris, dipping Cyrus’ severed head into a skin filled with human blood. ${ }^{111}$ Herodotus notes, "Of the many different accounts which are given in the death of Cyrus, this which I have followed appears to me most worthy of credit” (I: 202-214).

Herodotus' assessment of Cyrus as a leader of his people is, overall, a positive one. During the reigns of Cyrus and Cambyses, he says, no fixed tributes were required. Instead, "gifts" were brought by the nations to the king. Darius on the other hand, organized the empire into satrapies, and assigned fixed tributes to each of them. "On account of these and other like doings, the Persians say that Darius was a huckster, Cambyses a master, and Cyrus a father;...Cyrus was gentle, and procured them all manner of goods” (III, 89).

111. Herodotus' story of Cyrus' death at the hand of Tomyris numerous parallels with the non-canonical Hellenistic Jewish novel of Judith and Holofernes, preserved in the Apocrypha, and a popular subject of Renaissance art. 
In Laws (c. 360 BCE), the Greek philosopher Plato (427-327 BCE), who was born about two years before the death of Herodotus, suggests that under Cyrus, the Persians had a government that represented a harmonious mean between freedom and slavery:

In the reign of Cyrus they were freemen and also lords of many others: the rulers gave a share of freedom to the subjects, and being treated as equals, the soldiers were on better terms with their generals, and showed themselves more ready in the hour of danger. And if there was any wise man among them, who was able to give good counsel, he imparted his wisdom to the public; for the king was not jealous, but allowed him full liberty of speech, and gave honor to those who could advise him in any matter. And the nation waxed in all respects, because there was freedom and friendship and communion of mind among them. (Laws III: 694)

According to Plato, "Persians are shepherds—sons of a rugged land, which is a stern mother, and well fitted to produce sturdy race able to live in the open air and go without sleep, and also to fight, if fighting is required.” However, he goes on to explain, Cyrus did not recognize that, as dynastic scions of royal lineage, his sons were being educated “in the Median fashion” by women and eunuchs. Plato regarded Cyrus' successors as having been corrupted by a decadent royal upbringing, to which the Greeks ascribed the weakness of all subsequent Achaemenid kings, with the exception of Darius I, who as a usurper, had not been raised in a luxurious royal environment.

Xenophon (430-355 BCE), a contemporary of Plato, served as a commander in the battle for succession waged by two sons of Darius II, the great-grandsons of Darius I. He was a leader of the rear guard of the "army of ten thousand” mercenary Greek soldiers who had been left unemployed by the end of the Peloponnesian War. They had been recruited by Cyrus the Younger (c. 424-401 BCE) to help him overthrow his brother 
Artaxerxes II Memnon. ${ }^{112}$ Xenophon’s Cyropaedia (“The Education of Cyrus”), is a novelistic treatise that views the Cyrus the Great as having been the embodiment of royal virtues, and the product of a Persian education that designed "to make their citizens from the beginning incapable of setting their hearts on any wickedness or shameful conduct whatsoever" (2:3).

Xenophon’s idealized Cyrus “generally behaves and sounds like a perfectly pious Greek.” ${ }^{113}$ As in Herodotus, Cyrus is the son of the Persian king, Cambyses, and Mandane, daughter of the Median King Astyages (2:3). However, there is no mention in the Cyropaedia of his grandfather attempting to kill him. Instead, Cyrus becomes king of the Medes peacefully and legitimately by marrying the daughter of his uncle, Cyaxares, Astyages’ son. Xenophon portrays the Medes and Persians as allies and Cyrus as the loyal vassal of his father-in-law when he conquered Lydia and Babylon. ${ }^{114}$ Less interested in reenacting the past than in portraying what he considers to be an the ideal ruler, "Xenophon shapes a story of Cyrus which is composed of dialogues that were never spoken, battles that never took place, and people summoned and dismissed from

112. Michael Grant, The Ancient Historians (New York: Barnes and Noble, 1970), 33.

113. Deborah Levine Gera, Xenophon's Cyropaedia: Style, Genre and Literary Technique (Oxford: Oxford University Press, 1993), 55.

114. In the Anabasis $(3.4 .8,11-12)$, Xenophon asserts that the elder Cyrus had led a revolt against Astyages and had established Persian rule over that country before conquering Lydia and Babylon. Cyaxares is generally regarded by scholars as a fictional character. See Stadter, 464; Gera 100. According to Herodotus, Cyaxares was the name of Astyages' father (I:74). 
the written page without any shadow of historical reality."115 According to the Cyropaedia, Cyrus died peacefully in Persia, after a lengthy discourse to his sons and his people, and was buried at Pasargadae (7:4-28).

Roland Kent suggests that Xenophon wrote the Cyropaedia as a corrective to Artaxerxes II's' vicious propaganda against his brother, Cyrus the Younger, that extended to his namesake as well. Evidence of Memnon's smear campaign against the elder Cyrus can be found in the Persica of Ctesias, the Greek physician of Artaxerxes II Memnon for 15 years. A fragment of the Persica preserved by Nicholas of Damascus claimed that the elder Cyrus was neither an Achaemenian by birth nor the offspring of Cambyses and Mandane, but of a lowly Mardian named Atradates. After winning the favor of Astyages, Cyrus usurped his throne. ${ }^{116}$ Another Persica fragment, preserved in a summary by the patriarch Photiu, "transmitted nothing but a slanted view dominated by the tortuous machinations of wicked princesses and the murky conspiracies of crafty eunuchs," which, according to Briant, "is not without some adumbration of the 'Orientalism' of the modern period, which analyzes the courts of the Near East through the haze of some very debatable readings, permeated mostly by observations on the murmurs of the harems and the decadence of the sultans.”117

115. Philip A. Stadter, “Fictional Narrative in the Cyropaideia,” American Journal of Philology, 112, no. 4. (Winter, 1991), 463.

116. Roland G. Kent, “The Oldest Old Persian Inscriptions,” Journal of the American Oriental Society, 66, no. 3. (July - Sep., 1946), 211-212.

117. Briant, 7-8. 
Even Xenophon's hagiographic novella that idealizes Cyrus both as a man and as a ruler concludes with disgust with, and disparagement of, the degeneration of Cyrus' successors. In the epilogue (Chapter 8) of the Cyropaedia, Xenophon recounts that, immediately after Cyrus' death, strife ensued between his sons and rebellion broke out in what had been the greatest and most glorious kingdom in the ancient world. Deceit, impiety, cowardice, injustice, gluttony, drunkenness, laziness, love of luxury, and disdain for honor began to corrode the Persian body and soul. "The Persians of to-day and their allies are less religious than they were of old, less dutiful to their kindred, less just and righteous towards other men, and less valiant in war” (8:27). Furthermore, by Xenophon’s time, they could no longer be trusted to keep their word:

In the early days, I am aware, the king and those beneath him never failed to keep the oaths they had sworn and fulfill the promises they had given, even to the worst of criminals. In fact, if such had not been their character and such their reputation, none of the Hellenic generals who marched up with the younger Cyrus could have felt the confidence they did: they would not have trusted a Persian any more than one trusts them to-day, now that their perfidy is known (8:2-3).

As nationalist propaganda written in wartime, the Greek authors emphasized the superiority of the Greeks over "the Median menace." John Curtis holds the Greeks responsible for the representation of Achaemenid Persia "as a hotbed of tyranny and despotism, as an opponent of freedom and democracy" rather than a culturally hospitable and religiously tolerant empire in which local religions were allowed to flourish. ${ }^{118}$ Abtahi views this as Greek civilization redefining itself in order to explain and to justify its own behavior:

118. Peter Aspden. “Enlightened Empire.” Financial Times, September 2, 2005. 
Feeling threatened by the dynamics of the Iranian Empire, the Greeks developed their sense of national identity through negative self definition, presenting the Iranians as the decadent Barbarians who sought to conquer all of Europe by any means. In this dangerous enterprise, the Greeks had the heroic mission to defend the small but rational Europe from the vast but chaotic Asia. Exaggerations built upon exaggerations helped them finally to shape a myth of the victimized prey, but master of a refined civilization, attacked by the greedy Asiatic hordes, led by their Oriental despot. A myth that has endured until the present day, and which continues to be reproduced in different moulds, as convenience requires. $^{119}$

Greek representations of Persians have made their way into modern scholarship through "the classics" of Greco-Roman literature. ${ }^{120}$ Nineteenth century European historians selectively drew upon the writings of ancient Greek authors to substantiate and justify their own “Orientalist” attitudes, making the struggle between West and East the centerpiece of their accounts, while ignoring the long history of constructive cultural exchanges between Greece and Persia. Shahrokh Razmjou points out that "After the wars between Greece and Persia, there were good relations between the two, but we never hear about that.” ${ }^{21}$ Neil MacGregor points out that the absorption of Greek literature into the European intellectual and cultural mainstream laid the foundations for

\section{Abtahi, 29.}

120. The pro-Greek bias of European orientalism still pervades various disciplines within academia, and continues to shape attitudes toward Persia and what became, in 1935, modern Iran. "Interesting and important as the oriental races are, there is an intellectual and spiritual difference which conditions all our relationships with them," wrote Francis Godolphin, Princeton University College Dean in 1942, "This is not true of our relationship to Greece, and it is this underlying kinship which makes it possible to return to the Greeks in one generation and another, finding new insights and new inspiration from each renewal of contact." See Godolphin's Introduction to George Rawlinson's translation of Herodotus' The Persian Wars (New York: Modern Library/Random House, 1942), vii. Edith Hamilton described the ancient Greeks as "the first Westerners," asserting that the spirit of the West, the modern spirit, is a Greek discovery, and the place of the Greeks is in the modern world. The Greek Way (New York: WW Norton, 1993), 15. 
the stereotypes that helped create the division between West and East, and between Europe and Asia, "those stereotypes of the freedom-loving, tough European versus the servile, luxurious, effeminate, despotic Asian.”122

As Briant points out, historians cannot choose their sources, and considering the meager evidence available from other sources, the Greek authors cannot be dispensed with: “...(W)e have no choice but overwhelming reliance on Greek historiography to reconstruct a narrative thread. However much one may rail, not to say become frustrated, at the nature of their works, the situation becomes even more awkward when we must do without them!”123

\section{Jewish Text and Tradition: “Cyrus, My Servant”}

The Hebrew Bible (TaNaKh, known to by Christians as the "Old Testament") views Cyrus from the perspective of the redactors of the prophetic books and historiographic "writings" (ketuvim). The Book of Isaiah speaks of Cyrus as God's anointed (mashiach), the liberator, restorer and redeemer, chosen by Yahweh to subdue all nations for the sake of Jacob and Israel. Aroused in righteousness, the God of Israel declares, it is Cyrus who "will rebuild My city and let My exiles people go...” (Isaiah 45:1-13). ${ }^{124}$ The Hebrew Bible concludes with the verse: "Thus said King Cyrus of

121. Aspden. "Enlightened Empire.”

122. Aspden. "Enlightened Empire.”

123. Briant, 7-8.

124. Modern scholars attributed this passage to Deutero-Isaiah, also known as "Second Isaiah,” a 6th century author believed to have been the author of chapters 40-55 of Isaiah. 
Persia: The Lord God of Heaven has given me all the kingdoms of the earth, and has charged me with building Him a House in Jerusalem which is in Judah. Any one of you of all His people, the Lord his God be with him and let him go up (II Chronicles 36:23).”125

As previously noted, Morton Smith points out numerous parallels between Isaiah 40-48 and the first half of the proclamation in the Cyrus cylinder. Smith suggests that Second Isaiah reflects Judean disappointment that Cyrus did not wreak vengeance on the Babylonians, as the Hebrew prophets who hailed him as a messianic restorer had foretold that he would. Instead of ravaging Babylon when he conquered it, he adopted its administrative structure and even its language, Aramaic. The good will and cooperation of the Babylonians were far more useful to Cyrus than pleasing the smaller and less politically significant Judeans, who wanted the Babylonians punished for sacking Judah and destroying its Temple. ${ }^{126}$ Nor did Cyrus impose uncompromising monotheism as the law of the empire, as Isaiah had hoped. While granting the Judeans the right to return to Judah and rebuild the Temple in Jerusalem, Cyrus also restored the Babylonian god Marduk to local preeminence and reinstituted the authority of the Babylonian priesthood. He returned the Assyrian and Elamite gods to their former status in their own ancestral territories. Cyrus appears to have been a henotheist who believed in the power of the various gods worshipped throughout his realm, and sought their favor. ${ }^{127}$

125. Cf. Ezra 1:2-3.

126. Smith, "II Isaiah and the Persians,” 417-418.

127. Dandamaev and Lukonin, A Political History of the Achaemenid Empire. (Leiden: e.J. Brill, 1989), 54-57. 
Interested neither in religious tolerance for its own sake nor in the propagation of Judean Yahwism as the one true faith, Jon Berquist suggests that Cyrus pragmatically sponsored the restoration of the temples and shrines of the various gods within his empire in order to enhance state control of the Persian empire’s resources. His decrees regarding religious restoration "emphasize imperial domination, as expressed in the centralized ability to move populations and property, including symbolically valuable religious property." ${ }^{128}$ Cyrus' edict mandating the financial support of the Judean returnees was less a declaration guaranteeing religious autonomy than an indicator of a voluntary resettlement policy that provided financial incentives for reinforcing of the peripheries of the Persian empire such as Yehud. Under Babylonian imperial administration, subject populations like the Yehudim were relocated to the more easily defensible center of the empire in order to increase its productivity. Cyrus, on the other hand, wanted to reinforce the expanding boundaries of the Persian empire and fortifying its peripheries:

A more robust and secure population in these areas increased the possibilities for tribute and peace along the military supply routes. Since temples were involved in the collection of tributes and taxes as well as in the ideological grounding of the society, the periphery received a certain level of support for rebuilding its religious institutions. Cyrus intended that the support of Jerusalem and other similar areas would assist his policies of imperial expansion. ${ }^{129}$

Voluntary emigration of some Yehudim to their ancestral territory reinforced the southern boundary of Cyrus' empire, as a prelude, or alternative, to the conquest of Egypt.

128. Berquist, 25.

129. Berquist, 26. 
The actual reconstruction of the Jerusalem Temple apparently did not take place during Cyrus' reign, nor that of his son Cambyses. According to the disjointed and inconsistent incidents recounted in the biblical Book of Ezra, the émigrés set up an altar for daily, new moon, and festival sacrificial offerings when they arrived in Judea. They also arranged for the shipment of cedar wood from Tyre and the hiring of carpenters. In the second year of their return, under the supervision of Zerubbabel and Yeshua, the foundations of the Temple were laid. (Ezra 3:1-3). Nevertheless, the rebuilding of the Temple did not commence.

The fourth chapter of Ezra recounts that, during the reign of the Persian king Artaxerxes, ${ }^{130}$ enemies of the post-exilic community (tzaarei Yehuda-lit. "tormentors of Judah”), who had been resettled in Samaria during population transfers carried out under the Assyrian king Esarhaddon (reigned 680-669 BCE), offered to participate in the Temple’s reconstruction. The community’s leaders, Zerubbabel and Yeshua, rejected their assistance, whereupon the "peoples of the land" attempted to intimidate the

130. According to the Babylonian Talmud ((Rosh Hashanah 3b), Artaxerxes means "king" in Persian and was a title by which all of the Persian kings were known, just as all Egyptian kings were called Pharaoh. In point of fact, Persian kings from Darius on adopted the title "Shahanshah" ("king of kings"). Artaxerxes is a Greek corruption of the Old Persian Artâkhshatra. The first Artaxerxes (ruled 465-424 BCE) son of Xerxes ,was known as Artaxerxes Longimanus ("the long handed,") because his right arm was somewhat longer than his left, according to Plutarch, who also wrote (c. 359 BCE) that he was the most remarkable of the Persian kings for his "gentle and noble spirit." Artaxerxes II Memnon ("the mindful”), was the eldest of four sons of Darius II and Artaxerxes I's daughter Parysatis. He ruled Persia from 404-358 BCE, and was succeeded by his son Artaxerxes III Ochus (ruled 358-338 BCE), and his grandson Artaxerxes IV Arses (ruled 338-336 BCE). Since Rabbinic chronology compressed 206 years of Persian rule over Judah into the Jewish years 3390-3428 (corresponding to 371-333 $\mathrm{BCE}$ ), the kings of Persia during this period all bore the name Artaxerxes during this period, although the rabbis must certainly have been aware that Darius III Codomannus, who ruled Persia during the last 5 years of the Achaemenid empire, did not. 
returnees. They succeeded in deferring any progress on the reconstruction of the Temple "from the days of Cyrus king of Persia until the reign of Darius king of Persia” (Ezra 4:1$5)$.

After an eighteen year hiatus, the Judean leadership finally decided to move forward with the Temple's reconstruction. Alarmed, the Persian governor of the TransEuphrates region alerted King Darius that the Judeans were rebuilding their Temple, and that the Judeans insisted that Cyrus had granted them the authorization to do so during the first year of his reign (Ezra 5:6-17). During a search of the royal archives, a scroll of Cyrus' decree was found in a palace library in Medea. Darius then instructed the royal governor to cooperate with Judean leaders, and to impose the death penalty on anyone who dared to interfere with their work. Thus, "by the decree of the God of Israel and by the decree of Cyrus, Darius and Artaxerxes,” the Temple was completed and rededicated with joy on the third day of the month of Adar, during the sixth year of the reign of King Darius (Ezra 6:14-16).

As Yaacov Shavit points out, although this date was recorded in a scroll that became part of the Bible, it was never observed as a festival, nor were the return from the Babylonian exile and the resumption of the Temple service ever accorded any status in Jewish active memory. ${ }^{131}$ It did not even appear in Megillat Taanit (“Scroll of Fasts”), a post-Hasmonean tract listing the days of the year on which fasting and communal mourning were prohibited on account of a joyous event once having taken place on it.

131. Shavit, 54-55. 
Flavius Josephus (37-c. 100 CE), in his Antiquities of the Jews (c. 94 CE), claims that Cyrus had read the prophecy of Isaiah, written 140 years prior to the demolition of the Temple by the Babylonians, during the first year of his reign, seventy years after the exile of the Judeans. Cyrus "admired the divine power," and "an earnest desire and ambition seized upon him to fulfill what was so written." Cyrus summoned the most eminent Jews of Babylon and gave them permission to return to their own country and rebuild their city, Jerusalem, and its Temple. According to Josephus, the tribal leaders of Judah and Benjamin, along with the Levites and priests, immediately set out for Jerusalem, "and yet did many of them stay in Babylon, as not willing to leave their possessions” (11:1:2-3).

Josephus depicts the neighboring peoples as plotting to undermine the Temple's construction from the outset, of which Cyrus was unaware, being pre-occupied with his war against the Massegetae. It was not Cyrus, Josephus states, but his son Cambyses who, being "naturally wicked," prohibited the reconstruction of the Temple during his six year reign, on grounds that the Jews of Judea had been seditious and warlike, their kings powerful and tyrannical, and the city of Jerusalem "an enemy to kings" (11:2:2). In the second year of Darius' reign, Cyrus' authorization for the reconstruction of the Temple and Jerusalem was rediscovered, and the rebuilding of the Temple proceeded. After seven years of construction, the Temple was finally completed on the $23^{\text {rd }}$ day of the month of Adar, in the ninth year of the reign of Darius (11:7:104-106). The regnal year of the Temple's completion in Josephus differs by three years from that of the account found in Ezra 6:15, and the date is different, although both accounts place the Temple's completion in the month of Adar. Josephus' date also is not accorded any recognition or 
status in Jewish tradition. The discrepancy in dating, however, confirms Shavit's observation that the date of the Temple's completion and dedication, although recorded, was not commemorated. "Cyrus' role in Jewish history has been relegated to the margins of the Jewish historical memory and he has not been accorded the status and honor he deserves.”132

The case of Cyrus raises some interesting questions about Jewish historiography in the five centuries before and after the Common Era, particularly whether authors and commentators had access to the texts now cited by present-day scholars in their constructions of ancient historiography. Josephus himself "was known only to a handful of Jews, and he was not the source of the Jews' knowledge of the Second Temple or the ancient history of their nation.”133 As a historian, Josephus relied on writings that may or may not have included present-day versions or their sources. ${ }^{134}$ It is uncertain whether Josephus had access to what is now the biblical book of Ezra. Since the day was apparently never commemorated, there would have been little incentive for later editors of either text to harmonize Josephus and Ezra.

132. Shavit, 52.

133. Shavit, 53.

134. Present day known versions available today include the Books of Ezra in the Hebrew Bible and the Greek Esdras 1, which was preserved in the Apocrypha, although not canonized by Jews. 1 Esdras incorporates textual parallels to some of what is now the Book of Nehemiah. Modern scholars surmise that at one time the biblical books of Ezra and Nehemiah were a single scroll, but were separated into two "books" not later than the third century CE, since Origen shows them divided as they are today. See F. Charles Fensham, "The Book of Ezra," in Bruce M. Metzger and Michael D. Coogan, The Oxford Companion to the Bible (Oxford, New York et al,: Oxford University Press, 1993), 219-221. 
Medieval Rabbinic tradition treats Cyrus with considerable ambivalence. According to the Babylonian Talmud (Megillah 12a), redacted under Sassanian rule, it was Divine will that Cyrus rebuild the Temple, but Cyrus left the task to, or, alternatively, granted this privilege to, the Jewish people instead, much to the annoyance of the Almighty. Medieval homiletic and exegetical (midrashic) commentaries disagree in their assessments of Cyrus' role in facilitating the return of the Judeans and his role in the rebuilding of the Temple. Pesikta Rabbati, an eighth century collection of homiletic commentaries, faults the Jews who preferred to remain in Babylon, rather than Cyrus, for the failure of the Divine Presence (shekhina) to return to Jerusalem. Seder Eliyahu Rabbah (c. ninth century) ${ }^{135}$ states that Cyrus had wept and groaned over the destruction of the Jerusalem Temple, and thus became a Divine instrument for bringing the Divine Presence back to the Holy Mountain. ${ }^{136}$ Shir haShirim Rabbah, another midrashic work of approximately the same period, says that, having given the Jews permission to return to Jerusalem and rebuild the Temple, Cyrus had a change of heart and forbade further emigration from Babylon to Jerusalem because he did not want the country to be weakened by the departure of the Jews. ${ }^{137}$

135. The date of Seder Eliyahu Rabba is a matter of considerable scholarly dispute, but its origins seem to be not later than the ninth century, according to Eli Lederhendler, who points out that Seder Eliyahu Rabba is the first Jewish source to articulate the idea that "the existence of rival empires was providential for Jewish survival.” The Road to Modern Jewish Politics: Political Tradition and Political Reconstruction in the Jewish Community of Tsarist Russia (New York: Oxford University Press, 1989), 164, no. 2.

136. Meir Zlotowitz, ed. and transl., The Megillah: The Book of Esther (Brooklyn, NY: Mesorah Publications, 1989), xvi.

137. Shavit, 54. 
As for the slow progress in the reconstruction of the Temple, biblical commentators Rashi (1040-1105) and Malbim (1809-1879) contend that Cyrus himself was the king who stopped the work on the Temple in the Book of Ezra. ${ }^{138}$ However, Elijah ben Solomon, the Vilna Gaon (1720-1797), argues that Cyrus was too righteous a person to have interrupted the construction of the Holy Temple, and the work must therefore have been stopped by his successor, Artaxerxes, who, according to rabbinical chronology, reigned for less than a year. ${ }^{139}$ The most positive assessments of Cyrus in later rabbinic tradition exculpate him at the expense of his successors, leading to an overall negativity towards the period of Persian rule over Judea during the Achaemenid period.

Shavit suggests that the medieval rabbis may have retrojected onto Cyrus their disappointment with Julian “the Apostate,” the Roman king who, in 362 CE, announced he was going to rebuild the Jewish Temple but did not do so during his brief reign, which led to the conflation of the King of Persia and the King of Rome in Jewish "historical memory." Similarly, Shavit cites the possible association or conflation of Cyrus with Chosroes, the Persian king who briefly succeeded in gaining control of Palestine from the Byzantines (614-626 CE). Again, this led to unfulfilled expectations of another restoration of Jews to Jerusalem and the rebuilding of the Temple by a Persian king-

138. Zechariah Fendel, Legacy of Sinai:. A History of Torah Transmission with World Backgrounds from Creation to the Close of the Geonic Era [1-4798] (New York: Rabbi Jacob Joseph School Press, 1981), 120, no. 74.

139. Fendel, Ibid. 120, no. 74. 
hopes dashed first by Byzantine victory, and again, almost immediately, by the Muslim conquest. ${ }^{140}$

These unfulfilled longings for messianic restoration and redemption may have worked against the preservation of Cyrus' memory. Another factor, however, may have been "the "Persian problem in Jewish historiography": the overwhelming evidence that the three primary texts of Judaism—-the Hebrew Bible, the prayer book (siddur) and the Talmud—were all produced or redacted under Persian rule and/or a Persian-influenced environment. Nonetheless, Jewish religious historiography compressed the entire period of Achaemenid rule over Judea to as few as 39 years, in order to validate the prophecies in the biblical Book of Daniel.

Academic Jewish historians have further marginalized the Jewish-Persian connection by referring to the descendants of the members of exilic community who chose not to return to Judea when offered the opportunity to do so as the "Jews of Babylonia.” This designation ignores, or at least obscures, the historical fact that, from the time of its conquest by Cyrus in (539 BCE) until the Islamic conquest (650 BCE) — over a thousand years_-"Babylonia” was an integral part of the Persian empire. ${ }^{141}$. With the exception of the relatively brief period between Alexander's conquest of Babylon in 331 BCE and the Parthian conquest of most of the Achaemenid Empire by 141 BCE, when Persia was under Seleucid rule, the Jews of Babylonia were, in point of fact, living in Iran. The Talmud, a compendium of rabbinic debates in late antiquity and became the

140. Shavit, 64-65. 
source of authority concerning Jewish praxis, was very much a product of the interaction of Persian and Jewish culture in late antiquity. ${ }^{142}$ Both the rabbis of the rabbinic tradition and Jewish enlightenment scholars who constructed the timeline of the modern Jewish historical tradition most likely preferred to forget this.

The ultimate paradox of Cyrus in Jewish tradition is that, although the Bible depicts him as a divinely-chosen messianic restorer of the exiled Judeans to Zion, who made possible, even if he did not personally complete, the reconstruction of the Jewish Temple in Jerusalem, neither he nor his Declaration were ever accorded an honored place in Jewish collective memory. ${ }^{143}$ While passages depicting the destruction of the Temple in Jerusalem are read in synagogues and commemorated on no fewer than four fast days during the Jewish year, and prophetic passages envisioning peace, prosperity and the rebuilding of Jerusalem were carefully calibrated by the rabbis to provide solace and optimism in the wake of desolation, the passages recounting the role of Cyrus, and indeed the entire period of the return from Zion, are rarely studied, read, or even talked about:

...neither the Return to Zion nor the Cyrus Declaration which inaugurated it achieved a prominent position in the active historical memory, and only during the brief period of Hibbat Zion did they serve as an active, that is, a "useful past. This, therefore, is an exemplary case of a striking difference between the

${ }^{141}$ See Richard Kalmin, Jewish Babylonia between Persia and Roman Palestine (Oxford: Oxford University Press, 2006).

${ }^{142}$ Yaakov Elman, "Middle Persian Culture and Babylonian Sages: Accommodation and Resistance in the Shaping of Rabbinic Legal Tradition," in The The Cambridge Companion to the Talmud and Rabbinic Literature, eds. Charlotte E. Fonrobert and Martin S. Jaffee (Cambridge: Cambridge University Press), 165-197.

143. Shavit, 66. 
importance of a unique, formative, even "messianic," event at the time it occurred, in the consciousness of its contemporaries, and in Jewish history, on the one hand, and the status it achieved in historical writing throughout the ages and

in the formative, organized Jewish historical memory through the various "agents of memory" on the other. ${ }^{144}$

Cyrus disappeared from Jewish "active memory” for over 1,500 years.

\section{Christian Emancipators and Restorationists: Cyrus Redivivus}

During the 18th-19th centuries, maskilim — proponents of the European Jewish Enlightenment movement (haskalah) seeking to attain civil and political rights for Jews within the states of Europe-began drawing comparisons between Cyrus and Christian rulers who appeared to be on the verge of emancipating the Jews in their domains. Eliahu Morpurgo, an Italian Jewish maskil, compared the Hapsburg Emperor Joseph II to Cyrus in 1781 for issuing his Edict of Tolerance. Ironically, in its final form the Edict did not extend religious toleration to Jews. ${ }^{145}$ The poem "The Road of My People," written by the Russian-Jewish poet Yehudah Leib Gordon in 1865, cast Russian Tsar Alexander II in the role of "Cyrus my shepherd." Gordon praised Alexander II for ordering that Jewish children be sent to non-Jewish schools in order to promote their Russification and integration, claiming God had "roused his spirit as the heart of

144. Shavit, 54.

145. Shavit, 65. As issued in its final form in 1782, however, the Edict of Tolerance explicitly prohibited Jews from worshipping publicly and from printing prayer books, from living in rural areas, excluded them from citizenship and becoming masters in craft guilds, banned the use of Hebrew and Yiddish in public business transactions, and, in 1787, required the adoption of German-sounding surnames from a list approved by the government. See Jeffrey Alexander, The Civil Sphere (New York: Oxford University Press, 2006), 464. 
Cyrus!”146 Ironically, nearly sixty years earlier, Tsar Alexander I had denounced Napoleon as "the Antichrist and the enemy of God" for emancipating the Jews. ${ }^{147}$

In the spring of 1799, during his Palestine campaign against the Turks, Napoleon Bonaparte declared the Jews to be "the rightful heirs of Palestine." He called upon them to seize the moment "to claim the restoration of civic rights among the population of the universe which have been shamefully withheld from you for thousands of years, your political existence as a nation among the nations” and the natural right to worship publicly in accordance with the precepts of the Jewish faith. ${ }^{148}$ Barbara Tuchman compares Napoleon's proclamation to the Jews to his call to Arabs, encouraging them to

146. Shavit. 66. For a detailed discussion of the process and consequences of the emancipation of Russian Jews under Alexander II, see Simon M. Dubnow, History of the Jews of Russia and Poland (Bergenfield, NJ: Avotaynu, Inc., 2000), 276-321.

147. Austria had also disapproved, as did the Prussian Lutheran Church. See Weider, above.

148. A French dispatch issued with Napoleon's permission issued on April 17, in advance of the proclamation ( that was published in Le Moniteur on April 19, which states [my translation], "Bonaparte has published a proclamation in which he invites all the Jews of Asia and Africa to come gather themselves under their flags to establish ancient Jerusalem,” Napoleon, who never actually reached Jerusalem, because of British support for the Mamluks tore up the proclamation, which has never been found. A manuscript copy of a translation of the proclamation into German was found in the archives of a Viennese family in 1940. Barbara Tuchman, Bible and Sword: England and Palestine from the Bronze Age to Balfour (New York: Ballantine Books, 1984), 163-167. This challenges question Weider's claim that the "Letter to the Jewish Nation from the French Commander-in-Chief Buonaparte" that he includes in Appendix 2 of his paper, was translated from the 1799, as he claims. According to Arie Morgenstern, the question of whether or not Napoleon issued such a decree was debated at the Second World Congress of Jewish Studies held in Jerusalem in 1957, with Prof. M. Verete contending that there was no evidence supporting the issuance of the proclamation. Nevertheless, Morgenstern points out that Franz Kobler, in Napoleon and the Jews (Jerusalem, 1975) and N.M. Gelber, "Napoleon I and the Land of Israel," published in Sefer Dinberg, ed. Yitzhak Baer et al, (Jerusalem, 1949), pp. 263-268, believe that Napoleon did issue a proclamation, the date for which Morgenstern gives as April 20, 1799. See Arie Morgenstern, Hastening Redemption: Messianism and the Resettlement of the Land of Israel, transl. Joel A. Linsider (Oxford and New York: Oxford University Press, 2006), 10; 216, n. 26; 
revolt against the Turks—a military stratagem that could not possibly have succeeded, given the circumstances in which he found himself in Syria. ${ }^{149}$ A Jewish Sanhedrin of one hundred and eleven representatives of the 40,000 Jews of France and northern Italy proclaimed Napoleon Bonaparte the modern Cyrus on March 9, 1807, ${ }^{150}$ announcing that "God of the world, who rules over all the kings of the earth, chose him as a ruler and commander of these lands." 151 The Sanhedrin compared Napoleon to Cyrus because he granted Jews full civil and political rights as citizens of France and Napoleonic Europe, not because of his scheme to restore Jews to Palestine under French protection. ${ }^{152}$ Nevertheless, Napoleon's unheeded call to Europe's Jews to return to their biblical homeland was not without consequences.

For after Napoleon it became axiomatic that whenever the powers fell to fighting in the Middle East someone would propose the restoration of Israel, and equally axiomatic that the someone would be indulging in a happy dream not only of

149. Ibid., 163. Nissan Peretz points out that upon his arrival in Egypt, Napoleon attempted to win over the local population by convincing that he was there to fight for Islam: "Nous sommes les vrais Musulmans" (We are the true Muslims). Focus East: Early Photography in the Near East 1839-1885 (New York: Harry N. Abrams, 1988), 20.

150. Ben Weider, "Napoleon and the Jews.” Paper presented to the International Congress of the International Napoleonic Society, Allessandria, Italy, June 21-27, 1997 <http://www.napoleon-series.org/ins/weider/c_jews.html>. First convened by Napoleon's decree on the 23rd of August 1806, this would be the last time Sanhedrin met.

151. Shavit, 81, no. 28. France was the first country in Europe to grant Jews full civil and political rights, and Judaism became the third official religion of France. After his defeat at Waterloo, some of the privileges French Jews had gained were retracted until 1830, and a backlash against Jews in other parts of Europe, particularly the Papal States where Pope Pius VII forced Jews back into the ghettos and required them to wear yellow badges. Weider, op.cit.

152. According to Tuchman, Napoleon tore up the Letter to the Jewish Nation, and it was preserved only in a German translation found in the archives of an Austrian family in 1940. Otherwise it was preserved only 
acquiring thereby a sphere of influence over a vital strategic area, but also of drawing to his own side all the supposed wealth and influence of world Jewry. Political effort on behalf of the Jews was never exerted except as a by-product of other nations' quarrels, as when the British assumed the Palestine Mandate in the twentieth century. But one cannot deny Napoleon credit for the idea. ${ }^{153}$

British zeal to restore the Jews to Palestine emerged later than in France. Nevertheless, partly in response to the upheavals resulting from the French Revolution and the Napoleonic wars, England experienced a resurgence of deeply-rooted millenarianism, as Michael Ragusis notes. Hebrew prophecies were reread for their predictions about when and how the restoration of the Jews to Palestine would indicate the imminence of the Second Coming. Jews became the subject of books, pamphlets, and sermons which declared them to be at the center of a global crisis, and of world history itself: “The on-going war between France and England became reconfigured as a contest over which of the two powers, 'atheistical' France or Christian England, would lead the Jews back to their homeland, with Napoleon variously represented as the anti-Christ and the Messiah (even of specifically Jewish birth)."154 Due to the geopolitical climate, particularly the need to exert some influence over the collapsing Ottoman Empire, the

153. Tuchman, 163-164. Michael Ragussis points out that "The status of the Jews, historically subject to the radical fluctuations of political power that occurred in the different countries in which they lived as aliens, nonetheless had never gone through such dramatic swings as in the three-decade period from 1789 to 1819-that is, from the emancipation of the Jews in France as a result of the French Revolution, to the plans of Napoleon and others to restore them to their homeland in Palestine (for which the world had to wait more than a century), to the revival of medieval atrocities in Germany, including pamphlets that called for the immediate expulsion or outright slaughter of the Jews. "Writing Nationalist History: England, the Conversion of the Jews, and Ivanhoe,” ELN, Vol. 60, No. 1 (Spring, 1993), 181.

154. Ragusis, 181. 
imperatives of millenarianism and geopolitics would converge. ${ }^{155}$ Henry Temple, better known as Lord Palmerston (who served as Foreign Secretary for most of the decade between 1830-41 and from 1846-51, and as Prime Minister from 1855-58 and 1859-65), wrote to the British ambassador in Constantinople, Viscount John Ponsonby, on Aug. 11, 1840:

There exists at the present time among Jews dispersed all over Europe, a strong notion that the time is approaching when their nation is to return to Palestine...It would be of manifest importance to the Sultan to encourage the Jews to return and to settle in Palestine because the wealth which they would bring with them would increase the resources of the Sultan's dominions, and the Jewish people, if returning under the sanction and protection and at the invitation of the Sultan, would be a check upon any future evil designs of Mehemet Ali or his successor...I have to instruct Your Excellency strongly to recommend [the Turkish government] to hold out every just encouragement to the Jews of Europe to return to Palestine. ${ }^{156}$

Palmerston's stepson-in law, Lord Anthony Ashley Cooper (soon to become the $7^{\text {th }}$ Earl of Shaftesbury), who headed the London Society for Promoting Christianity Among the Jews (also known as "the Jews' Society"), saw this move as "a prelude to the Antitype of the Decree of Cyrus." ${ }^{\prime 57}$

Ashley was an ardent, religiously motivated social reformer who forced the Ten Hours bill ("the Factory Act") through Parliament, that, Tuchman notes, is "credited with staving off revolution in the industrial countries," the Lunacy Act that sought to end the

155. Shimoni, 61.

156. Quoted in Tuchman, 175. For a full discussion of the symbiotic relationship between restorationist British Evangelists and the political proponents of settling "the Eastern question" by fostering Jewish settlement of Palestine under British protection, see Tuchman, 175-223. Also see Gideon Shimoni, The Zionist Ideology (Waltham: Brandeis University Press, 1995), 61-62

157. Isaiah Friedman, “Gideon Shimoni-the Zionist Ideology” (Review), Israel Studies 3:1 (1998), 257-258. 
abuse of the mentally ill, the Lodging House Act (considered by Charles Dickens to be "the finest piece of legislation ever enacted in England" until that point), and the Mines Act. His philanthropy was based on the gospels, and his Restorationism was based upon a millenarian vision of a world awaiting redemption. For him, Jews were not a people, "but a mass Error that must be brought to a belief in Christ in order that the chain reaction leading to the Second Coming and the redemption of mankind could be set in motion.”158 However, as was the case during other "Cyrus-ian" moments, there was little enthusiasm to be found among Jews, particularly among British Jews, for colonizing Palestine. With the exception of Sir Moses Montefiore, president of the Jewish Board of Deputies, ${ }^{159}$ Jews were far more interested in securing their rights as Englishmen than in fulfilling the conversionist and restorationist fantasies of British Evangelicals. ${ }^{160}$

When the originator of the joint British-Prussian missionary project, Carl Josias Bunsen, learned that the Church of England had gained the unprecedented right to construct a Protestant Church and operate schools in Jerusalem, he called upon the British government to be "Cyrus redivivus" and assume the responsibility for restoration of the Jews. ${ }^{161}$ Together with Shaftesbury, Bunsen succeeded in laying the groundwork for an agreement between the Prussian and British governments to establish a bishopric "to

158. Tuchman, 178.

159. Tuchman ,193.

160. Tuchman, 210.

161. Paul Charles Merkley, The Politics of Christian Zionism 1891-1948 (London and Portland, OR: Frank Cass, 1998), 12. 
plant under the banner of the Cross, God's people on the mountains of Jerusalem.” Between 1841 and 1883, the bishopric of Jerusalem, jointly administered by the Church of England and the United Evangelical Church of Prussia, was permitted by the Ottoman Sultan to only evangelize among the Jews. ${ }^{162}$

More than any other single figure before him or since, Laurence Oliphant, a late nineteenth century British author and mystic, “was endowed with the lofty title of 'Cyrus' (a distinction which reveal more about the expectations of the time and the repertoire of current images than about the figure to whom it was applied)."163 Oliphant, "the first Christian Zionist who made a serious effort to advocate a British public policy supporting a Jewish homeland in historical Palestine,”164 unveiled a detailed and apparently practical plan for Jewish colonization, which he actively advocated with the apparent support of Benjamin Disraeli:

For a short period between 1878 and 1880, it [Oliphant's plan] combined the three elements that seem to have been historically necessary for any practical

162. Ibid. 13-15. Ragussis points out that Christian calls for Jewish restoration to Palestine in the early 19th century had coincided with the development of nationalism in both Germany and England that was both anti-French and anti-Jewish, illustrating what Ragussis considers to be the political consequences of Romantic medievalism. In the wake of the expulsion of Napoleon from German territories, the German “Hep! Hep!” riots of 1819 invoked the war cry of the crusaders who massacred Jews in 1096. "Writing Nationalist History: England, the Conversion of the Jews, and Ivanhoe,” ELN, Vol. 60, no. 1 (Spring, 1993), 181. Having denied the Jews the right to citizenship they requested from the Congress of Vienna in 1815, many German territories attempted to return the Jews to their medieval status. See Amos Elon, The Pity of It All: A History of the Jews in Germany, 1743-1933 (New York: Metropolitan Books, 2002), 103.

163. Shavit, 70 .

164. Norma Claire Moruzzi, “Strange Bedfellows: The Question of Lawrence Oliphant's Christian Zionism.” Modern Judaism 26:1 (2006), 57. 
achievement: an indigenous Jewish nationalism provided by Disraeli, even if it was romanticized almost out of recognition; evangelical Christian support provided by Oliphant and his circle of highly placed, spiritually curious friends; and Great Power strategic interest that both Disraeli and Oliphant, in their different ways, could appreciate and try to forward. After 1880, the three strands unraveled, not to be pulled together again until the changed circumstances of 1948 provided for a new Zionist consensus. ${ }^{165}$

Eastern European Zionism, however, did not actively coalesce into a mass movement until after the pogroms that swept through southern Russia in the spring of 1881, in the wake of the assassination of Tsar Alexander II. When it did, numerous pleas were written to Oliphant. A letter from the Lovers of Zion movement in Nikolaev to Oliphant in 1882, told him that Divine Providence had given him the "scepter of leadership" of the Jews. ${ }^{166}$ That same year, Moshe Leib Lilienblum wrote to Oliphant:

“...when Israel was in Babylon, they had little strength to find freedom for their souls. Then the lord roused the spirit of his messiah, Cyrus King of Persia, who called for freedom for those imprisoned in exile and allowed them to migrate to the land of their ancestors...God willing, you will succeed in returning the redeemed to the land of their ancestors and they will call you a new name: the messiah of Israel. ${ }^{167}$

The Bucharest Society for the Settlement in the Holy Land also sent a missive to Oliphant:

...our history teaches us that the Highest always chooses the chosen ones. It preferred the redeemers of this despised and persecuted people, not one of the children of Israel, but of the Righteous Gentiles. Cyrus King of Persia was the chosen one of God His Messiah. God roused his spirit and he spread the word throughout his kingdom...And who knows if God did not choose His chosen one

165. Moruzzi, 68.

166. Quoted and cited by Shavit , 70.

167. Quoted and cited by Shavit , 70. 
Oliphant... and due to your efforts, honorable sir, the cornerstone of our community will be laid in the ruined and desolate land of our forefathers... ${ }^{168}$

Nonetheless, there were those who derided Oliphant as a "false Cyrus," and denied his bearing resemblance to the Persian monarch. Oliphant ultimately proved to be a disappointment. After 1880, Oliphant, while still involved with working toward colonization of Palestine, became increasingly focused on the religious aspects of colonization, with little interest in promoting Jewish nationalism. ${ }^{169}$

Restorationist zeal also made its way to the U.S. On March 5, 1891, President Benjamin Harrison and Secretary of State James G. Blaine received a petition from William Blackstone, an ardent restorationist, to promote the convening of an international conference whose purpose would be to give Palestine back to the Jews, who had been expelled from their ancient home. Four hundred and thirteen prominent Americans signed the petition, among them several members of Congress, including the Speaker of the House of Representatives and the Chairman of the Senate Foreign Relations Committee; the Chief Justice of the Supreme Court; the most prominent and wealthy industrialists of the day; numerous journalists and publishers and prominent Christian and Jewish clergymen. Just as the Congress of Vienna had given Serbia to the Serbians, Bulgaria to the Bulgarians, and Cyprus to Great Britain, the Jews could be given Palestine by the world powers. ${ }^{170}$

168. Quoted and cited by Shavit, 71.

169. Moruzzi, 65.

170. Michael Oren, Power, Faith, and Fantasy: America in the Middle East 1776 to the Present (New York and London: W.W. Norton, 2007), 278-279. 
The "Blackstone Memorial" appealed to Harrison and Blaine to seize the historic opportunity not only to remedy a historic injustice, but to further the aims of the creator by helping to fulfill the Divine blueprint for prophetic fulfillment: "Not for twenty-four centuries, since the days of Cyrus, King of Persia, has there been offered to any mortal such a privileged opportunity to further the purposes of God concerning his ancient people." 171 While no conference was ever convened, "the notion of American sponsorship of a Jewish return to Palestine was firmly planted in many minds."172 Nevertheless, while Blackstone continued to lobby for the U.S. to lead the campaign to establish a Jewish state, Harrison declined, as did successive U.S. presidents Grover Cleveland and William McKinley. Europeans did not support the Blackstone Memorial, and the Ottomans, fearing that Zionism might be tool for dismantling their empire, responded by sharply curtailing all Jewish immigration to Palestine. ${ }^{173}$

Stephen Wise, an American rabbi and prominent Jewish leader, attempting to enlist the support of U.S. President Woodrow Wilson for the Zionist cause, pointed out that King Cyrus had become enshrined in the Bible because he had enabled the exiled Jews of his country to return to Jerusalem and to rebuild their Temple. Wilson, the son of a minister and of a minister’s daughter, was enraptured, and he responded, "To think that I...should be able to help restore the Holy Land to its people."174 On May 14, 1948,

171. Merkley, 68-69.

172. Merkley, 69.

173. Oren, 279.

174. Merkley, 79. 
eleven minutes after its provisional government proclaimed its existence, President Harry S. Truman granted de facto recognition to the State of Israel. A few months after the conclusion of his presidency, when introduced as the man who helped to create the Jewish State, Truman objected to the modesty of "helped to create," and declared "I am Cyrus. I am Cyrus.”

\section{Israel's Peripheral Vision}

During a brief period that began just a few years after the discovery of the Cyrus Cylinder in 1879, and in the aftermath of Russian pogroms that followed the assassination of Tsar Alexander II, the members of the Hovevei Zion (Lovers of Zion) movement viewed themselves as re-enacting the "Return to Zion." When the Balfour Declaration by the British Government was issued in 1917, it was briefly viewed as a repetition of the Cyrus Declaration and as a typological turning point. According to one member of the Zionist Executive Committee in 1920, the Balfour Declaration and Mandate were worthy of being recalled alongside "the documents given to the Jews by Cyrus and Artaxerxes." ${ }^{176}$

As anger with British policies limiting Jewish emigration to Palestine set in during the 1920s, Cyrus once again became the historical precedent for Jewish disappointment with the unfulfilled promises of a foreign ruler. The Jewish national home was “defective, even defiled” by being born under the authority of a foreign power:

175. Moshe Davis, "Reflections on Harry S Truman and the State of Israel," in Truman and the American Commitment to Israel, ed. Allen Weinstein and Moshe Maoz (Jerusalem: Magnes Press, 1981), 83.

176. Shavit, 74. 
....anyone who continued to refer to the Cyrus Declaration and to compare the Yishuv to the Return to Zion was depicted as a political minimalist, a defeatist will to be content with a "day of small things," a miserable autonomy granted by the grace of foreigners. If there was a need for an analogous historical model, there were other, more positive, periods that could be cited: the period of the settlement of the Land of Canaan and the kingdom of David and Solomon, or other chapters in the Second Temple from the time of the Hasmoneans on. ${ }^{177}$

While Shavit says it would be difficult to argue that the Lovers of Zion movement arose for the express purpose of restoring the memory of Cyrus, or the return to Zion that he authorized, “processes, decisions and trends were endowed with historical 'validity' or a historical illustration after-and not before-the fact, by the memory of the historical precedent." Shavit argues that after the brief resuscitation of the "return to Zion" by the Lovers of Zion movement, shortly after the discovery of the Cyrus cylinder in 1879, the Cyrus model "no longer had content or signs perceived as relevant or useful” and ceased to have a role in active Jewish memory. ${ }^{178}$

In the case of Cyrus, except for references to him in historical literature and various legends, neither his name nor his deeds are preserved in the "collective memory" in any other way (not even in Hebrew first names as was Alexander of Macedonia): no coins or stamps immortalize him, no popular legends or songs are devoted to him, there are no sites connected with his name, no ceremonies commemorate him on any public holiday. Thus, although his name is indeed retained in canonic historical memory, has never been forgotten or repressed, it has also never moved to a central position. ${ }^{179}$

Nevertheless, Shavit has perhaps overlooked the entrance of Cyrus into the historiography of the State of Israel and his return to "active collective memory" in structuring the perceptions of the Jewish state's relationship with Iran. While avowedly

177. Shavit, 75 .

178. Shavit, 76 .

179. Shavit, 54. 
secular in his personal religious practices, David Ben-Gurion, Israel's first Prime Minister, who crafted not only Israel's first post-revolutionary ideology of "statism" (mamlakhtiyut), ${ }^{180}$ but the "strategy of the periphery" in foreign policy, enjoyed playing the role of amateur Bible scholar. He frequently gave talks in which he drew connections between biblical personalities and events and the challenges to the modern state of Israel. In one of these, entitled “The Image of Cyrus the Great," delivered in the spring of 1951, Ben-Gurion pointed out that the two verses that conclude the Hebrew Bible (II Chronicles 36:22-23) were devoted to Cyrus, a unique privilege extended to a non-Jewish ruler. Cyrus deserved this privilege, as well as the praise of the Hebrew prophets, BenGurion declared,

not merely because of his proclamation and the permission which he gave the Babylonian exiles to return to their land and rebuild the Temple in Jerusalem. Cyrus was also one of the greatest figures, from a general historical point of view. He was one of the greatest military men in the history of nations, one of the greatest politicians of all time and, in addition, a merciful and big-hearted man at a time when there were few exceptional individuals among the great conquerors. ${ }^{181}$

Ben-Gurion noted that "it is not clear if this year marks 2,500 years since Cyrus' decree or if it is next year.” What was beyond doubt, however, was "Cyrus' greatness as a mighty and enlightened ruler, and as the first to permit the return to Zion,” which should be remembered by Israelis and all civilized people.

180. David Biale, Power and Powerlessness in Jewish History (New York: Schocken, 1987), 152.

181. David Ben-Gurion. Ben-Gurion Looks at the Bible. Transl. Jonathan Kolatch (Middle Village, NY: Jonathan David, 1972), 265. 
Iran had recently extended de facto recognition to Israel in March of 1950. Jewish

Agency personnel were permitted to maintain a very limited, low profile, presence in

Teheran, in order to facilitate the emigration of Jews from Iraq. ${ }^{182}$ The recollection of Cyrus took on a new, albeit clandestine role, to play in the historiography of the return to Zion.

In spite of the Islamic Revolution, some Israelis have been reluctant to give up the near-messianic faith that another Cyrus will eventually restore the mythic strategic partnership that had once existed between Israel and Iran. In a 2004 interview, Eliezer Tsafrir, who headed the Mossad in Iran and Iraq during the 1960s and 70s, expressed his optimism that the "Cyrus connection" between Israel and Iran would yet be revived and ultimately triumph over all other strategic and political considerations:

Whatever the name of Iran-Pars, Elam, Media—and whatever the name of Iraq-Babylon, Assyria, Akkad, Sumer-there was always a rivalry and sometimes war [between the two]...The Iranians know this—and this is why I am optimistic about Iranian-Israeli relations in the future. "Koroush-e Kabir" [Cyrus the Great] knew that there is a common interest between the two sides of the Middle East-Iran and Israel. That is why Koroush let Ezra and Nehemja come back and rebuild the temple. It was obviously an interest of his in order to dominate Babylon [Iraq]. Iran is Moslem but not Arab, and [to keep this balance] Iran needs another [non-Arab] people [who share that] common interest. ${ }^{183}$

\section{From Zoroaster to the Islamic Republic}

Within Iranian tradition, Cyrus' status-even his existence-has been surprisingly more ambiguous, even precarious. Although the ancient history of Iran

182. Uri Bailer, "Top Hat, Tuxedos and Cannons. Israeli Foreign Policy from 1948 to 1956 as a Field of Study.” Israel Studies 7:1 (2002), 38-39. A generous bribe to Iran’s Prime Minister was apparently one of the motivating factors in the de facto recognition.

183. Parsi, Treacherous Alliance, 78; 300 no. 51 
during the Achaemenid period is thoroughly documented by a wide variety of written sources—-historical chronicles, law decrees, royal inscriptions, orders issued by kings and satraps, official correspondence, letters written by private individuals, tax receipts, religious and scientific literature, marriage contracts, promissory notes-the overwhelming majority date from the reign of Darius or later. The trilingual Behishtun documents found near Kermanshah, inscribed on a cliff along the ancient caravan route connecting Babylon and Ecbetana, relate events that took place at the end of Cambyses' rule and during the early years of Darius I, ${ }^{184}$ but they do not mention Cyrus.

Nor was there a place for Cyrus and the Achaemenids in the official national historiography of Persian’s Sassanian dynasty, the Khwaday-namag. Composed under the influence of Zoroastrian priests in the fifth and sixth century CE, the Khwaday-namag traced the lineage of the Sassanians to the Avestan kings of the northeastern Iran rather than to the Achaemenids. According to Shahbazi, Zoroastrian scholars relied upon Babylonian, rather than Greek dates (the only two sources available to them) when they constructed their chronology. While Cyrus, Darius, and Xerxes played a dominant role in Greek historiography of the Achaemenid period, traditional Zoroastrian chronology, followed the Babylonian chroniclers, who had little reason to esteem them. ${ }^{185}$

The ruins of Cyrus' palace at Parsa, which the Greeks called Persepolis (the city of the Persians), was renamed Takht-i-Jamshid, "the abode of Jamshid," the Iranian

184. Dandamaev and Lukonin, 368.

185. A. Shapur Shahbazi, “The 'Traditional Date of Zoroaster' Explained,” Bulletin of the School of Oriental and African Studies, University of London, 40:1 (1977), 32. 
mythic hero, by the Sassanians in the third century CE. ${ }^{186}$ Richard Frye has suggested that "all Iranians had a common mythology but not a common epic," and the Achaemenids of western Iran did not recount stories of the eastern rulers (kavis), ${ }^{187}$ while the secular heroic and mythical traditions of northeastern Iran became the basis for the national epic of the Parthians ${ }^{188}$ and later the Sassanians. ${ }^{189}$ Since the early Islamic period, Cyrus' tomb, near the palace of Pasargadae, has been known as Qabr-e Madar-e Sulaiman ('the tomb of the mother of Solomon"), perhaps, some sources suggest, an ingenious renaming of the site to prevent conquering Arabs from desecrating or destroying it.

The Quran (Sura Al Kahf-“the Cave,” 18:83-98) tells of Zolqarnain, a great ruler of the east, the west, and a third direction, who treated the peoples he conquered with compassion and justice. Religious scholars and commentators have long debated to which of the two great pre-Islamic conquerors-Cyrus or Alexander the Great-the Quran refers. ${ }^{190}$ Molana Abolkalam Azad (1888-1958) pointed to the numerous

186. Vesta Sarkhosh Curtis, “The Legacy of Ancient Persia.” Forgotten Empire: The World of Ancient Persia, edited by John E. Curtis and Nigel Tallis (Berkeley: University of California Press, 2005), 250-252.

187. Richard N. Frye, The Heritage of Persia (New York and Toronto: Mentor, New American Library, 1963), 57.

188. Sarkhosh Curtis, 225.

189. Sarkhosh Curtis , 234.

190. In The Holy Qur'an: Text, Translation \& Commentary (Elmhurst, NY: Tahrike Tarsile Qur'an, 1987), Appendix VII, pp. 760-765, an essay by A. Yousuf Ali, "Who was ZolQarnain?” provides an extended overview of the arguments concerning Zolqarnain's identity with Alexander and unequivocally concludes that he was Alexander. Contemporary commentators who argue that Zolqarnain was Cyrus include Allameh Seyyed Muhammad Husayn Tabatabaei, 
allusions to Cyrus in the Bible, as well as the dream of Daniel (8:20-21), in which a ram with “two horns” signifies Cyrus’ Persian empire. (One possible translation of Zolqarnain is “two horned.”) As a monotheist, Cyrus, who was granted power and authority by God, was closer to being a proto-Muslim than Alexander. ${ }^{191}$ Jews figure prominently in these Muslim commentaries, not only because the Bible provides texts and imagery that can be invoked in the identification, but because the figure of Cyrus is so closely connected in much of Islamic literature with his being the savior of the Jews.

Early Islamic historiographers do not list Cyrus in their chronologies. The ninth century historian Dinawari (828- c. 890) identifies the Persian king who allowed the Jews to return to their homeland with Bahman. ${ }^{192}$ At the end of the tenth century, the Khorasanian polymath Abu Raihan al-Biruni, in his chronological tables of the kings of Persia, lists Cyrus in his table of the kings of Persia according to western historiographers, and identifies him with the king who was known as Lohrasp by earlier chronographers. Cyrus is preceded by Koresh, who al-Biruni identified with Kay Khosrow. ${ }^{193}$ (This is particularly intriguing since Koresh is the Hebrew name for what is

Grand Ayatollah Naser Makarem Shirazi, Abul Kalam Muhiyuddin Ahmed, and Sayyid Abul Ala Maududi.

191. Baha’eddin Khoramshahi, “History of Iran: Zolqarnain.” Iran Chamber Society website. ttp://www.iranchamber.com/history/articles/zolqarnain_cyrus_quran.php (accessed October 8, 2007).

192. Sarkhosh Curtis, 252.

193. Abu Raihan Muhammad ibn Ahmad al-Biruni. The Chronology of the Ancient Nations, an English version of the Athar-ul-Bakiya, ed. and translated by Edward Sachau (London: William Allen, 1879), 115. 
invariably translated into English as Cyrus.) Both Kay Khosrow and Kay Lohrasp are found on al-Biruni's chronological listing of the kings that follows "the opinion of the generality of the Persians.” However, al-Biruni identifies Kay Lohrasp, midway through his reign, as having "sent Bukhtanassar [Nebuchanezzar] to Jerusalem, who destroyed it." ${ }^{194}$ After assessing the discrepancies between the Persian genealogies of the eastern Avestan tradition and those of the western historiographers, al-Biruni writes, "I am inclined to think that they [the Greek historians] confounded the kings of Persia with their governors of Babylon.” ${ }^{195}$ Nor is Cyrus, by that name, counted among the heroes of Persia's past by al-Biruni's contemporary, Ferdowsi, whose Shahnameh (Book of Kings) is Iran's national epic.

The early twelfth century Muslim historian Ibn Balkhi appears to be describing Persepolis in his Farsnameh, and identifies the images of Darius, Xerxes, and Artaxerxes as those of the mythic king Jamshid. The tomb of Cyrus at Pasargadae, which Ibn Balkhi refers to as "the tomb of Solomon's mother," was turned into a mosque in the thirteenth century, indicating that it was considered a site with religious significance. According to the Geography of Fars, by the fifteenth century historian Hafiz Abreu, Persepolis was one of a number of ancient sites near Shiraz visited by Iranian kings once a year. "They said that from the time of Jamshid there was a temple in that place, and the ancients regarded it as a good augury."196

194. al-Biruni, 112

195. al-Biruni, 114.

196. Sarkhosh Curtis, 253. 
In the Ardashir-namah (Book of Ardashir), by the fourteenth century JudeoPersian poet Mowlana Shahin-i Sharazi, Cyrus is the son of the biblical Queen Esther and the Persian king Ardashir. ${ }^{197}$ Bahman is another name of Ardashir, the son of Isfandiyar, in Ferdowsi's Shahnameh, and represents, according to Vera Basch Moreen, the fictitious "linchpin connecting Shahin's epic with Iran's great national epic.” According to the chronology of Dinwari, Bahman allowed the Jews of Babylon to return to Jerusalem.

Little is known about Shahin except that he wrote during the reign of the Il-khanid Sultan Abu Sai‘d (1316-1335), to whom he composed a panegyric. He recast parts of the Hebrew Bible into a versified Persian epic mold using the language, grammar and rhetorical forms of classical Persian poetry. ${ }^{198}$ Moreen compares Shahin to Ferdowsi (d. 1010), his greatest poetic influence, with whom he shares "the transcendent goal of commemorating and glorifying his nation's origins, history and ideals.”199 As Moreen points out, Ardeshir Bahman of Ferdowsi is much later chronologically than the events in

197. Vera Basch Moreen, In Queen Esther's Garden: An Anthology of Judea-Persian Literature (New Haven and London: Yale University Press, 2000) . 324, n.3. While not explaining that some versions of rabbinic chronology collapsed and conflated the events of the Persian period into as few as 39 years, just before the Achaemenids defeat by Alexander, Moreen points out that some midrashic sources makes Darius, rather than Cyrus, the son of Esther and Ahasuerus. She also cites various other contradictory midrashim ,according to which Esther's marriage to Ahasuerus is never consummated; Esther used birth control to prevent conceiving a child by Ahasuerus, or suffered a miscarriage, Nonetheless, Moreen concludes, "It seems highly plausible that there existed a local Jewish-Persian tradition claiming that Cyrus was the son of Esther, for this is explicityly stated in the fourteenth century midrashic work originating from Iran, Sefer pitron Torah, p. 33.” Ibid. 327, no. 50.

198. Moreen, 29.

199. Moreen, 13. 
the Book of Esther, which are conventionally ascribed by traditional scholars to the reign of Xerxes, who is generally associated with the biblical Ahasuerus (486-465 BCE).

Through the will of the Greatest Father, Esther Became pregnant, and when her time of birth came, God opened up for her the gates of purity, [And she gave birth] to a beautiful, sun-cheeked boy [Worthy] of the crown and throne of Jamshid.

The shah rejoiced at the child's birth' He uprooted oppression from the world. He rolled back the tax on caravans, Distributed much gold and money to the poor... When Cyrus turned Four years old, his face was like the spring And like a tulip; that exalted princely jewel Indeed grew tall, a cypress. Without him, At dawn and sunset, the shah found no repose. ${ }^{200}$

In the Ezra-nameh (Book of Ezra), the leaders of Persia’s Jews, Ezra, Mattatiah, the sole princely descendant of the Jewish royal house, and the prophets Haggai and Zekhariah, receive an audience with Cyrus, now the king of kings, and ask his permission to return to Canaan and rebuild the Temple there. Cyrus says he will grant their wish only if they agree to accept a cup of wine from him and drink it. The wine of gentiles being prohibited to Jews, Mattatiah must consult with Ezra and other Jewish leaders. A religious ruling (fatwa) decrees that they must drink the wine. The sun goes dark and the world goes into mourning. The next day, they return, drink from the cup of wine, and Cyrus gives the command that the kingdom of Canaan be rebuilt, including the Temple. $^{201}$

200. Shahin, Ardashir-nameh, quoted in Moreen, 103-104.

201. Moreen, In Queen Esther’s Garden,106-110. Moreen emphasizes that in both of Shahin's epics, "the purpose of the union of Esther and Ardashir is not only the immediate deliverance of Iranian Jews but the restoration of Jewish national sovereignty through Cyrus," 
Little is known about Shahin, except that he wrote during the reign of the Ilkhanid Sultan Abu Sai`d (1316-1335), to whom he composed a panegyric, and that he recast parts of the Hebrew Bible into a versified Persian epic mold using the language, grammar, and rhetorical forms of classical Persian poetry. ${ }^{202}$ Moreen compares Shahin to Ferdowsi (d. 1010), his greatest poetic influence, with whom he shares "the transcendent goal of commemorating and glorifying his nation's origins, history and ideals." 203

Although his poetic account sets out to retell a biblical story, Shahin’s epic does not follow the conventions or the content of the Jewish homiletic commentaries of medieval Europe, which make Darius, not Cyrus, the son of Esther. Rather, he testifies to the existence of an Iranian tradition of Jewish scholarship upon which he draws, including a little known fourteenth century midrashic work originating from Iran: the Sefer Pitron Torah. ${ }^{204}$ At the same time, Shahin is clearly looking to Ferdowsi's Shahnameh as his literary model. In making Cyrus, the Persian restorer of national sovereignty to the Jews, the offspring of Ardashir and Esther's union, Shahin “intertwines the fates and histories of Iran and Israel, attesting to his love of both.”205 As Moreen points out:

202. Moreen, 29.

203. Moreen, 13.

204. Moreen, 327, no. 50.

205. Moreen, 28. 
Judeo-Persian literature is the product of the confluence of two mighty literary and religious streams, the Jewish biblical and post-biblical heritage and the Persian (Muslim) literary legacy. The uniqueness of JP literature derives from the fact that it is a lovely amalgam in which these two streams, though recognizable, are strongly intertwined and interdependent. ${ }^{206}$

During the second half of the Qajar dynasty (1787-1925), Cyrus was rediscovered and became part of the narrative of nascent Iranian nationalism. ${ }^{207}$ Ironically, the sense of homeland and national cohesion arose in some measure in spite of, and in reaction to, the predations of Russia, Britain, and France. In his book alAsrar al-Ghaybiyyah li Asbab al-Madaniyyah (“The Secret of Divine Civilization”), Abd al-Baha Abbas (1844-1921), the son of the Bahai prophet Bah'aullah, cites both biblical $^{208}$ and Greek accounts of the greatness of Persia at the time of Cyrus the Great. Three hundred and sixty divisions of the Iranian empire extended from China and India in the east to Yemen in the west. Iran was "the heart of the world."209 When Russia occupied Iranian Azerbaijan in 1907, the Iranian nationalist poet Malek al-Shu'ara-ye Behar lamented:

This was the land of armies at the time of Cyrus. The resting place of warriors and the camp of the king For the games of the King and his prime I see it now, captive in the claws of insurgents. ${ }^{210}$

206. Moreen, 11-12.

207. Kamyar Abdi, “A History of Archaelogy in Iran.” American Journal of Archaeology 105:1, January 2001, 53.

208. e.g. Chronicles 36:22-23; Ezra 1:2; Esther 1:1, 8:9; Isaiah 45:1, 14; 49:12.

209. Juan R.I. Cole, “Marking Boundaries, Marking Time: The Iranian Past and the Construction of the Self by Qajar Thinkers.” Iranian Studies 29:1-2, Winter/Spring 1996, 44.

210. Cited by Abdi, History of Archaeology, 55. 
Archaeology played a significant role in the development of Iranian nationalism. Although archaeological exploration of Persepolis had begun as early as 1772, it was not until the 1924 that a full-fledged survey of the ruins was undertaken by Ernst Herzfeld a German Jewish archaeologist and art historian, with the encouragement of Nosrat adDowleh Firuz Mirza, a founding member of the recently formed Society for Iranian Heritage (Anjoman-e Asar-e Melli). After presenting his report, Herzfeld went on to excavate the site between 1931 and 1934, with the permission of the Iranian government and in cooperation with the Oriental Institute of the University of Chicago. ${ }^{211}$

Among Herzfeld's findings at Persepolis, which had been legally and scientifically excavated with the permission and cooperation of the Iranian government, in contrast to most of the earlier digging (and plundering) done by the French, were numerous clay tablets. They were written in Elamite cuneiform, attesting to everyday life in the Achaemenid empire circa 500 BCE. On long-term loan to the University of Chicago, the tablets became embroiled in a lawsuit brought by victims of a 1997 Hamas attack in Jerusalem, when a U.S. judge ruled that the Iranian government, which refused to recognize the jurisdiction of the court or the lawsuit and had not defended itself in the lawsuit, had materially supported Hamas. The judge's 2006 verdict further stated that Iranian-owned assets could be seized and sold at auction to compensate the plaintiffs. The University of Chicago argues that the Oriental Institute items were cultural property,

211. Abdi, History of Archaeology, 60. 
not "commercial assets," having never been before been bought or sold, and thus were exempt from seizure under the 1976 Foreign Sovereign Immunities Act. ${ }^{212}$

Reza Khan, who became Reza Shah Pahlavi, was impressed by Herzfeld's Persepolis excavations, which he visited four times. It was a talk by historian Arthur Upham Pope (1881-1969) on April 22, 1925, however, that is believed to have inspired and convinced him to try to revive the glories of ancient Iran by supporting its arts and cultural heritage. Surveying Iranian art from Achaemenid, Sassanian, and Islamic times, Upham expounded on Iran's cultural, artistic and spiritual contributions to world civilization. $^{213}$ Of all the foreign scholars who worked in Iran during the Pahlavi era, Pope is regarded as most influential in shaping Iranian nationalism. ${ }^{214}$

The revival of Iran's pre-Islamic heritage was one of three prongs, according to Abdi, that Reza Shah used against the Islamic clergy, who had opposed many aspects of Reza Shah's rule and his reforms aimed at promoting the modernization and secularization of Iran. Accusing the clergy of being reactionary and devoid of nationalist feeling, Reza Shah promoted the revival of Iran's Zoroastrian religious and cultural history and heritage. The solar calendar was restored. Public observance of Shi'ite festivals was muted, and the self-flagellation marches and pageants during the solemn

212. Amy Braverman Puma, “Worth millions...or priceless?” University of Chicago Magazine: 99:1 (Oct 2006) . For a full discussion of the legal aspects of the lawsuit, see James A. Wawrzyniak, "Rubin v. the Islamic Republic of Iran: A Struggle for Control of Persian Antiquities in America." At the time of this writing, the case is still in litigation, with the University of Chicago appealing the ruling.

213. Abdi, "History of Archaeology," 60.

214. Abdi, "History of Archaeology,” 61. 
month of Moharram were banned. Celebrations of the pre-Islamic Zoroastrian festivals, such as the new year festival of Noruz and the Indo-Iranian harvest feast of Mehragan, were revived and encouraged. ${ }^{215}$ Mohammad Reza Pahlavi continued his father's marginalization of Islam in Iranian historiography, calling himself "the light of the Aryans," and providing state sponsorship of "invented traditions” from pre-Islamic Iran while curbing the influence of the clergy. ${ }^{216}$ In March 1976, the Shah introduced the "Imperial Calendar," which fixed the first year of the Iranian calendar from the founding of Cyrus' empire 2,535 years earlier, rather than the migration of Mohammad from Mecca to Medinah in 622 BCE, according to the Muslim religious calendar, the use of which was prohibited by Ayatollah Ruhollah Khomeini. ${ }^{217}$

Jalal Al-e Ahmad, whose writings Dabashi considers to be the first crucial link in a chain of what would become known as the 'Islamic Ideology' and making it the most significant mobilizing force prior to the Iranian Revolution, ${ }^{218}$ condemned the state sponsorship and promotion of pre-Islamic culture under the Pahlavis, which he considered to be a plot by the West designed to distort Iranian historical identity. ${ }^{219}$ On a visit to Israel in 1963 as a guest of the Israeli government, Al-e Ahmad spoke warmly of

215. Abdi, "History of Archaelogy,” 63.

216. Abdi, "History of Archaeology,” 67.

217. Ruholla Khomeini, Islam and Revolution: Writings and Declarations of Imam Khomeini (1941-1980), translated and annotated by Hamid Algar (London et al, KPI, 1985), 312, no. 56.

218. Dabashi, Theology of Discontent, 41.

219. Quoted in Dabashi, Theology of Discontent, 82. 
the "vast arena of Irano-Judaic relationships, among them the reconstruction of the Temple by Cyrus. ${ }^{220}$ However, Al-e Ahmad, who developed the concept of "Westoxication" and condemned it, subsequently accused Western colonial powers of having only one passion—-“for Cyrus, Darius, and Zoroaster."221

Ali Shariati, another of the most influential thinkers in the pre-revolutionary period, argued for a return to Iran's Shi'ite heritage, rather than that of the Achaemenid period. In one of his lectures, Shariati pointed out that a number of secular Third World intellectuals in decolonized Africa, Asia, and Latin America were calling for a return to their "roots" and rediscovery of their history. Shariati declared:

Some of you may conclude that we Iranians must return of our racial [Aryan] roots. I categorically reject this conclusion. I oppose racism, fascism and reactionary returns. Moreover, Islamic civilization has worked like scissors and has cut us off completely from our pre-Islamic past. The experts, such as archaeologists and ancient historians, may know a great deal about the Sassanids, the Achaemedians [sic] and even the earlier civilizations, but our people know nothing about such things. Our people do not find their roots in these civilizations. They are left unmoved by the heroes, geniuses, myths, and monuments of these ancients empires. Our people remember nothing from this distant past and do not care to learn about the pre-Islamic civilizations... ${ }^{222}$

The pinnacle (or nadir) of the Pahlavi attempt at a nationalist neo-Zoroastrian revival, and of the appropriation of Cyrus by the Pahlavi shahs, was the extravaganza hosted by Reza Shah’s son and successor, Mohammed Reza Pahlavi, on October 12, 1971. Shojaeddin Shafa, an Iranian scholar, had originally proposed in 1960 that a

220. Dabashi, Theology of Discontent ,69.

221. Quoted in Dabashi, Theology of Discontent, 82.

222. Quoted in Ervand Abrahamian, Iran Between Two Revolutions (Princeton: Princeton University Press, 1982), 470. 
pageant be held at Persepolis to commemorate the 2,500th anniversary of the founding of the Persian empire by Cyrus. The event evolved into a three day encomium to the achievements of the Shah and the success of his White Revolution, at a cost of a hundred and sixty million tomans, according to one of its planners (approximately $\$ 22$ million dollars at the time, although rumors alleged the cost to have been between $\$ 50$ and $\$ 500$ million). ${ }^{223}$

British Foreign Secretary Michael Stewart was instrumental in arranging for the British Museum's loan of the Cyrus Cylinder to the Iranian government for the celebration, although his suggestion that the Museum present the cylinder to the Shah as a gift in order to secure his military and diplomatic cooperation was adamantly rejected by the Museum. ${ }^{224}$ The Shah, in turn, presented a replica of the cylinder to the United Nations, ${ }^{225}$ at a time when, his critics noted, his own human rights record was the subject of severe criticism. ${ }^{226}$ Months of planning culminated at Cyrus' tomb in Pasargadae, as television cameras beamed the image around the world, as the Shah, in full dress

223. Cyrus Kadivar, “We are awake: 2,500 year celebrations revisited.” The Iranian (online), January 25, 2002. http://www.iranian.com/CyrusKadivar/2002/January/2500/ (accessed February 4 2007).

224. Martin Bailey, "How Britain Tried to use a Persian Antiquity for Political Gain: The British Museum is to Loan the Cyrus Cylinder to Iran." The Art Newspaper 150 (September 2004).

225. United Nations Press Section, Office of Public Information, "Statement by U Thant, at Presentation of Gift from Iran to the United Nations, 14 October,” Press Release SG/SM/1553 HQ/265 October14, 1971.

226. Ahmad Faroughy, “Repression in Iran,” New York Times, March 16, 1975. 
uniform, opened the ceremonies by addressing the founder of his empire and putative forebear:

To you Cyrus, Great King, King of Kings, from Myself, Shahanshah of Iran, and from my people, Hail! We are here at the moment when Iran renews its pledge to History to bear witness to immense gratitude of an entire people to you, immortal Hero of History, founder of world's oldest empire, great liberator of all time, worthy son of mankind. Cyrus[,] we stand before your eternal dwelling place and speak these solemn words: Sleep in peace forever, for we are awake and we remain to watch over your glorious heritage. ${ }^{227}$

In a work entitled "Kurosh the Liar and Murderer" (Kurosh-e dorughin wa janayatkar), Ayatollah Sadeq Khalkhali (1926-2003), excoriated not only the Shah, but Cyrus and Jews. In a vitriolic response to the Shah's invocation of Cyrus, Khalkhali attacked Cyrus’ lifestyle and his repressive rule, criticisms that were directed at the Shah. Khalkhali, who would become infamous as the "hanging judge" and "the butcher" in his capacity as Chief Justice of the Islamic Republic's revolutionary courts, also took the opportunity to draw upon and cite classical Islamic sources that affirmed that Cyrus' mother was Jewish, ${ }^{228}$ and to vilify Jews as a race that has become "famous today as criminals and the enemies of mankind," for distorting the holy scriptures and bringing evil to the world. ${ }^{229}$

(Like the parallel "Persian problem in Jewish historiography," it appears that t one source of Shi'ite hostility towards Jews derives from accusations in Sunni scholarship

227. William Shawcross, The Shah's Last Ride: The Fate of an Ally (New York: Simon and Schuster. 1988) 46-47.

228. Cf. Shahin above.

229. In "Ayyam-e Enzewa. Khaterat-e Ayatollah Khalkhali awwalin hakem-e dadgahha-ye enghelab,” Nashr-e Sayeh, Tehran 1380, p. 223-306. My thanks to Walter Posch for this information , translation and citation. Personal e-mail correspondence, October 17, 2007. 
and tradition that Shiites were more like Jews than authentic Sunni Muslims. Steven Wasserstrom has documented nearly thirty ways in which Shi'ites (Rafida) were accused of having adopted the beliefs and practices of the Jews from classical Sunni heresiography. ${ }^{230}$ It seems hardly surprising, therefore, that the adoption of Shi'ism represents the most intense period of Jewish persecution in Iran, and that the association of Cyrus with Jews has done him no good in the eyes of the ulama, past or present.)

From his exile in Iraq, Ayatollah Ruhollah Khomeini denounced the millions of tomans spent on the "absurd” Cyrus celebrations, asking, "Are the people of Iran to have a festival for those whose behavior has been a scandal throughout history, and who are a cause of crime and oppression, of abomination and corruption, in the present age?”231 Eight years later, proclaiming the establishment of the Islamic Republic of Iran on April 1, 1979, Ayatollah Ruhollah Khomeini would also deride Cyrus' empire as a “satanic power” whose era of domination had finally ended after two and a half millennia:

This day of Farvardin 12, the first day of God's government, is to be one of our foremost religious and national festivals; the people must celebrate this day and keep its remembrance alive, for it is the day on which the battlements of the twenty-five hundred year fortress of tyrannical government crumbled, a satanic power departed forever, and the government of the oppressed-which is the government of God-was established in its place. ${ }^{232}$

${ }^{230}$ Steven M. Wasserstrom, Between Musim and Jew: the Problem of Symbiosis under Early Islam (Princeton: Princeton University Press, 1995), 101-103.

231. October 31, 1971. Ruholla Khomeini, Islam and Revolution: Writings and Declarations of Imam Khomeini (1941-1980), translated and annotated by Hamid Algar (London et al, KPI, 1985), 202.

232. Khomeini, transl. Algar, 266. 
The revolution's uncompromising anti-monarchical Islamist perspective not only rejected Cyrus, but Iran's entire pre-Islamic past. Pre-Islamic monuments became symbols of monarchical tyranny, although were no recorded incidents of archaeological sites or historical museums being vandalized. Archaeology was demeaned as "nothing more than a pseudoscience in service of the court to glorify despotism and justify royal oppression.” The University of Tehran's Archaeology department (the only one in the country at that time) was shut down entirely between 1979-1982, and would not resume operations until 1990. Foreign archaeologists were barred from working in Iran, and most Iranian archaeologists were forced to retire or to leave the country. ${ }^{233}$

Nevertheless, once the Shah was gone and the exigencies of the war with Iraq required national mobilization, the contribution that nationalism—initially denounced by the revolutionary leadership as un-Islamic and symptomatic of intellectual gharbzadeh — could make to the war effort prompted a reconsideration of the role that the ancient past might play in the formation of an Islamic Iranian identity. On April 20, 1991—two years after Khomeini's death—Iran's president, Ali-Akbar Hashemi Rafsanjani, visited Persepolis, where he wrote in the guest book,

In the name of Allah, the merciful, the compassionate, visiting the incredible remains at Persepolis provokes considerable national pride in every individual. By seeing these remains, our people will discover their own capabilities and the cultural background of their country, and will believe that they will recover their historical role in the future to uphold upon this talent and foundation, the blazing torch of Islam to light the path of other nations. ${ }^{234}$

233. Abdi, History, 70.

234. Abdi. History, 71-72. 
The revival of interest in Iran's pre-Islamic heritage has not been without criticism. In 2004, when the Tehran National Museum announced it would be putting on an exhibit on Cyrus, with the Cyrus Cylinder (on loan from the British Museum) as its centerpiece, the hardline conservative newspaper Jomhuri-ye Eslami denounced the idea: "The exhibition is an attempt to raise the rotting bones of the Shahs from the dead," an unsigned editorial complained. ${ }^{235}$ Accusations that Iran’s archaeological sites are being targeted for destruction evoke concern. The possibility of damage to Persepolis from the construction of the Sivand dam has aroused protest, particularly from Iranians now living outside the country. ${ }^{236}$

Nonetheless, in the popular view of most Iranians, Cyrus is a source of pride for Iranian history and culture. For Iranian exiles, whether they fled the country on account of the repressive measures of the Shah, or the Islamic regime that succeeded him, Cyrus provides a vision of what Iran once was, and should be. Hirad Abtahi, an Iranian by birth who has worked at the highest levels of the International Criminal Court, compares Cyrus' treatment of the Babylonians, and the other peoples of his domain, with the prescriptions of the Universal Declaration of Human Rights (UDHR) that would be emerge from the United Nations General Assembly in 1948.

235. Alberto Zonconato, "Iran: Islamic Conservatives Against Cyrus the Great,” ANSA News Service, April 23, 2004.

236. Kamyar Abdi, "Sensationalism vs. Rationalism.” Iranian.com, September 12, 2005. http://www.iranian.com/History/2005/September/Heritage4/. Abdi (accessed June 27, 2007), an Iranian archaeologist presently at the University of Vermont in Burlington, considers the claim that Persepolis will be damaged by the construction of the Sivand dam to be unfounded, as well as "an attempt to settle a grudge with the current government of Iran, and "a misuse of the archaeological record to promote a political agenda.” 
Irrespective of whether or not he was a Zoroastrian, a matter of considerable debate among modern scholars, ${ }^{237}$ Abtahi suggests Cyrus granted his subjects religious freedom, which was "a very early equisse of secularism. The center, in addition to not imposing its spiritual beliefs on the periphery, permitted religious practice according to conscience, rather than according to an imposed canon, anticipating Article 18 of the UDHR.,238 Abtahi sees within the text of Cyrus’ proclamation—-My numerous troops walked around in Babylon in peace, I did not allow anybody to terrorize (any place)"-a forerunner to what would respectively become Article 3 of the UDHR, guaranteeing of the right to life, liberty and security of person, and Article 5, the right not to be subjected to torture, or to "cruel, inhuman or degrading treatment or punishment."

Abtahi credits the behavior of Cyrus and his troops toward conquered peoples, as recorded in the cylinder, as prefiguring Article IV of the Geneva Convention protecting civilians during wartime from murder, rape, and displacement from their homes in times of war by 2,500 years. ${ }^{239}$ Instead of massacring or forcibly transferring populations to or from vanquished territories, Abtahi sees Cyrus as anticipating the Article 9 of the UDHR, which guarantees freedom of movement and the right to leave and return to one's

237. Scholars are divided on the dating of Zarathushtra (Zoroaster). For the fullest account of the various aspects of the controversy over when Zarathushtra lived, See A. Shapur Shahbazi, "The 'Traditional Date of Zoroaster' Explained," Bulletin of the School of Oriental and African Studies, University of London, 40:1 (1977), 25-35.

238. Hirad Abtahi, "Reflection on the Ambiguous Universality of Human Rights: Cyrus the Great's Proclamation as a Challenge to the Athenian Democracy's Perceived Monopoly on Human Rights.” The Dynamics of International Criminal Justice: Essays in Honour of Sir Richard May, ed. Hirad Abtahi and Gideon Boas (Leiden: Martinus Nijhoff, 2006), 13.

239. Abtahi, 14. 
country. ${ }^{240}$ Reading into the cylinder's reference to the abolition of the corvee the implication that Cyrus abolished or limited involuntary labor, Abtahi even suggests Cyrus complied with the spirit of UDHR Article 4, and with Article 7 of the International Criminal Court statute, which prohibit servitude, slavery, and the trafficking in persons. $^{241}$

Questioning “the assumption that Cyrus the Great promoted 'human rights' wherever he went,” Hamid Dabashi faults “the laudatory Orientalist language” in which such views of ancient Persia are narrated as being "of an entirely antiquarian, nostalgic and imperial disposition, with very little to offer toward a free and democratic nation state.”242 Yet for most Iranians, Cyrus remains a cultural icon, ready to leap from historiography to "active memory” when needed.

\section{Summary}

Through a diachronic and synchronic examination of the persona of Cyrus, numerous issues unfold. The ancient Babylonian texts, and the subsequent ejection of the three major Achaemenid rulers from Babylonian chronology upon which the Zoroastrian priesthood would rely in their construction of Avestan historiography, bear testimony to the long and close involvement of Iran in what is present-day Iraq. From the Greeks emerge the first texts to argue that there is a "clash of civilizations" between "the West

240. Abtahi, 16.

241. Abtahi, 15.

242. Hamid Dabashi, Iran: A People Interrupted (New York; The New Press, 2007), 22-23. 
and the rest," which provide the discursive basis for nineteenth and twentieth century Orientalism, in which Persia (now Iran) represents and reifies the Other.

The irony that the biblical image of Cyrus, as the protector and messianic restorer of the Jews, is one that, although found in the Bible as facilitator of a major turning point in Jewish history, plays no role in the "active memory" of the Jewish religious tradition. This stands in glaring contrast to the eagerness of dispensationalist Protestants to claim the mantle of Cyrus for themselves and bring about the restoration of the Jews to Palestine. Contemporary Israelis, as the next chapter will discuss, have largely (but not entirely) overwritten the association of Cyrus with the Shah of Iran that reinforced the "strategy of the periphery" with that of Haman, a descendant of the archetypal biblical enemy Amalek whose thwarted genocidal scheme is commemorated annually during the observance of the Jewish festival of Purim, who is restored to active memory by the antiZionist tirades of Iran's Islamic leadership on the one hand, and the emphasis on commemorative events that emphasize that "the whole world is against us."

Finally, there are the Iranians, suspended between no fewer than three images of Cyrus: one as the idealized ruler embodying Iran's ancient glory, who propounded and defended of the concept of human rights; another as a savvy, pragmatic politician and propagandist; and a third Cyrus - the first imperialist tyrant to aspire to a global empire. Who does Cyrus speak for, and who speaks for Cyrus? Where does Cyrus fit in, if at all, into Iran’s “Karbala Paradigm”? Cyrus epitomizes the diverse uses of religious images, political myth, and discourse that are recalled to active memory from literary and historiographic obscurity, and put to use in numerous ways in the construction of political myth and discourse. 


\section{CHAPTER III}

\section{CULTURAL AND RELIGIOUS SOURCES OF FOREIGN POLICY}

\section{Introduction}

That "culture matters" in state and societal behavior has become a platitude in numerous social science disciplines in the past decade, although how and why remains a matter of contention. As Nathan Glazer notes, while culture makes a difference, it is not easy to determine what in culture makes a difference, since many different outcomes have seemed to be compatible with the "great traditions" of any and every culture: "They have all had their glories and their miseries, their massacres and their acts of charity, their scholars and their soldiers, their triumphs of intellectual achievement and their descents into silliness or worse.” Glazer suggests thinking of traditions as storehouses from which suitable and useful practices may emerge. ${ }^{243}$

As the iconic image of Cyrus illustrates, these storehouses contain diverse myths, images, events, and personalities that can be put to use in a number of ways. "(M)odern nations and all their impedimenta generally claim to be the opposite of novel, namely rooted in the remotest antiquity, and the opposite of constructed, namely human communities so 'natural' as to require no definition other than self-assertion," as Eric

Hobsbawm observes. ${ }^{244}$ Yael Zerubavel explains that "National movements typically

243. Nathan Glazer, “Disaggregating Culture,” in Culture Matters: How Values Shape Human Progress, eds. Lawrence E. Harrison and Samuel P. Huntington (New York: Basic Books, 2000), 230.

244. Eric Hobsbawm, "Introduction: Inventing Traditions," in Eric Hobsbawm and Terence Ranger, eds. The Invention of Tradition. (Cambridge et al: Cambridge University Press, 1983), 4. 
attempt to create a master commemorative narrative that highlights their members' common past and legitimizes their aspiration for a shared destiny” by synthesizing the diverse memories of various individuals and groups. ${ }^{245}$ These "master commemorative narratives" serve as the basis for identity of what Benedict Anderson calls "imagined communities.” Blurring the boundary between real and imagined, these narratives create their own version of historical time by eclipsing, elaborating, condensing, conflating, and omitting events, and selecting specific events as turning points-markers for change that serve to highlight certain ideological principles underlying the master commemorative narrative. $^{246}$

Commemorations, particularly under state sponsorship, often take the form of what Hobsbawm calls "invented traditions": sets of practices, of a ritual or symbolic nature, that respond to novel situations by referring to suitable situations of the historic past, or by creating their own past. Governed by explicitly or tacitly accepted rules, invented traditions seek to inculcate certain values and norms of behavior through repetition, and do so by asserting or implying a largely fictitious continuity with preexisting practice. During major shifts in values and norms, invented traditions provide a stabilizing ritual and symbolic infrastructure, marked by new rituals and rhetoric. “Invented traditions” differ from custom, insofar as, even in so-called "traditional" societies, custom recognizes the need for flexibility and adaptation within the framework

245. Zerubavel, 214.

246. Zerubavel, 6-7. 
of formal adherence to precedent, and does not preclude innovation and change. ${ }^{247}$ Invented traditions, on the other hand, "attempt to structure at least some parts of social life within it as unchanging and materials for novel purposes. Every society has accumulated a large store of such materials in its past, and has an elaborate language of symbolic practice and communication is available for creation of the ritual and symbolic complexes of invented traditions.”248 Invention of tradition, Hobsbawm points out, is most likely to occur "when a rapid transformation of society weakens or destroys the social patterns for which the 'old' traditions had been designed.”,249

\section{Israel: A People that Dwells Alone}

As noted in the conclusion to the previous chapter, Jewish nationalism at the turn of the twentieth century expressed its ultimate disappointment with Cyrus, both in his ancient Iranian context and in his various reincarnations as the imperfect and incomplete restorer of Jewish sovereignty, by inventing new nationalist models that could serve a Jewish state constructed on nineteenth century concepts of nationalism for the "return to Zion.” The Bible became a primary source of these models, providing historical continuity, legitimacy of territorial claims, national heroes who could be emulated, and enemies who must be conquered and destroyed. The Bible also provided the language in which Israel's master commemorative narrative and the invented traditions sustaining that narrative could be expressed.

247. Hobsbawm, “Introduction: Inventing Tradition,” 1-2.

248. Hobsbawm, “Inventing Tradition,” 6.

249. Hobsbawm, “Inventing Tradition,” 4-5. 
The Hebrew Bible had played a central role in the European Jewish cultural revival, the haskalah (enlightenment), which began in Central Europe towards the end of the $18^{\text {th }}$ century. Maskilim looked to the Bible to demonstrate that Jews were not simply a religion, but an ethnic minority who shared a national past, and who should be permitted to fully assimilate into their European host nations. A hundred years later, however, the Bible would emerge as "an essential instrument for renewing Jewish independence in Palestine according to the ideals of modern nationalism...containing both a record of a national past and a powerful promise of a national future.”250

From the outset, the Zionist movement utilized the Hebrew Bible as its primary source of "invented traditions." The phrase "return to Zion" was gleaned from Psalm 126:1. The "Bilu” group of "Lovers of Zion,” who made their way to Palestine in 1882, took their name from an acronym of part of a biblical verse in Isaiah 2:5: "House of Jacob, let us go up...” Emigration to Palestine became known as aliyah (ascent), appropriating the image of the ascent to the Jerusalem Temple, required to offer sacrifices on the three biblical pilgrimage festivals, for travel to the Land of Israel for the purpose of settling there:

The return to the land, to Zion and Jerusalem, to the national independence of the First Commonwealth, to cultivation of the land and military valor, to speaking and creating in the tongue of Amos and Isaiah, received quasi-religious inspiration from the Bible which, for that generation, embodied its immediate tasks and visions, as if the present were recapturing the past. Leaders, authors and teachers all believed that, on the one hand, the Bible legitimized Zionism, in that it testified to Jewish ownership of the Land of Israel and foretold the nations return to its homeland, the rebuilding of the land, and the ingathering of the exiles; conversely, Zionism enhanced the glory of Scripture, in that it was realizing

250. Yaron Peleg, Orientalism and the Hebrew Imagination (Ithaca and London: Cornell, University Press, 2005), 23. 
biblical prophecy and thereby confirming the eternal truth of the Bible. Thus the Bible became an inspiring commentary on the present, just as the present became a concrete interpretation of the Bible. ${ }^{251}$

Nearly all Israeli leaders, political parties, and movements, past and present, have invoked the Bible to legitimate their policies and programs in one way or another, including adamant secularists who disdained any identification with the theological dogmas or ritual practices of traditional Judaism. The small but influential Canaanite movement of the 1940s and 1950s, for example, viewed the Hebrew Bible as a remnant of the literary heritage of the ancient Hebrews, a pagan nation that had lived in a Hebrewspeaking area called "the Land of Kedem" that included Palestine, Jordan, Syria, and Lebanon. For the Canaanites, the resettlement of Palestine was just the first step to the liberation of the Land of Kedem from the political domination, language, and culture of its Arab conquerors. The Canaanite ideal was a Hebrew state throughout the erstwhile Land of Kedem, in which there was total separation between religion and state and absolute equality among all of its citizens. ${ }^{252}$

In Zionist discourse and Israeli politics, the Scriptures often speak in contradictory voices and support of, or opposition to, diverse interests. ${ }^{253}$ Moshe Greenberg identifies three broadly discernable biblical voices in the State of Israel: 1)

251. Uriel Simon: "The Place of the Bible in Israeli Society: From National Midrash to Existential Peshat,” transl. David Louvish. Modern Judaism 19, no. 3 (October 1999), 217.

252. Boaz Evron, Jewish State or Israeli Nation? (Bloomington: University of Indiana Press, 1995), 208-209.

253. Moshe Greenberg, “On the Political Use of the Bible in Modern Israel,” in Pomegranates and Golden Bells: Studies in Biblical, Jewish and Near Eastern Ritual, Law, and Literature in Honor of Jacob Milgrom, ed. David P. Wright, David Noel Freedman and Avi Hurvitz (Winona Lake, IN: Eisenbrauns, 1995), 462. 
observant Jews, for whom the Bible is a source of Jewish religious instruction and authority; 2) non-observant Jews, for whom the Bible as a socially progressive document, articulating the eschatological hope for redemption of the Land of Israel and of its people in a peaceful world; and 3) non-observant nationalists for whom Scripture is their charter to the Land of Israel, a source of national pride, and as a mandate for a “muscular” imperial Israel that takes pride in war and conquest to affirm its independence and sovereignty. While these three scriptural voices alternate and mingle within Israeli political culture, Greenberg emphasizes that they remain distinct, selective, partial, and very much subject to interpretation. ${ }^{254}$ These voices draw upon the Bible as the basis for the religious paradigm of covenant, exile, and redemption:

Civilization centers on the divinely ordained mission of a chosen people, the descendants of individuals--Abraham, Isaac, and Jacob--who acquired a favored, unmediated relationship with the Creator of the universe. As a result of the primal covenant, his descendants have dedicated themselves to the service of God. This obliges them to preserve their separate identity from the non-elect. History is an unending struggle between the elect and everybody else (composed of Seventy Nations, according to the Midrash), the earthly enactment of a cosmic narrative of good and evil. At the culmination of history the Hebrew tribe, dispersed and chastened as a result of divine displeasure, is destined to gather in its scattered fragments from among the nations of the world and return redeemed-and acknowledged thus by the non-elect--to its original divinely promised homeland.

The Zionist myth, which secularizes the foregoing, has been the major motif in the conduct of Israel's foreign relations. ${ }^{255}$

This narrative is secularized into the Israeli "master commemorative narrative" of patrimony, exile, and return. The transformation from a religious to a secular paradigm

254. Greenberg, 463; 470. 
requires some significant, and radical, modifications to the biblical world view. Most prominent is the expurgation of all references to reward and punishment in the covenantal relationship depicted in the Bible. The promise of the land in Deuteronomy and the prophecies of return from exile are conditional, from a biblical perspective, and require absolute obedience to Divine precepts. The elimination of the concepts of reward and punishment makes the Bible primarily useful both as a myth of origins and a deed of title to territory.

Another fundamental change in the traditional Jewish myth of origins by Zionism is a re-gendering of the "people of Israel." One biblical image of the relationship of the "chosen people" relationship of the male God, Yahweh, to the Israelites is of husband to wife (Jer. 2:1-2). Some of the harsher prophetic passages depict this relationship as deeply dysfunctional, with Israel portrayed as an adulteress contaminated by the impurity of foreign seed (Jer. 2:20-22; Jer. 3:6-11). In the Zionist recasting of the metaphor, the collective Jewish people and its land are lovers, with am yisrael (the nation of Israel) cast in the role of the heroic male, while "the Land" (ha'aretz) is transformed into the beloved, feminized moledet. In schools and in the army, courses on Israeli history, ethnology, geography, geology, and botany are a single curricular subject known as yedi'at haaretz (knowledge of the land). "Those who coined the phrase were undoubtedly aware of the biblical meaning of yedi'a, an act of sexual possession," observes historian Meron Benvenisti:

255. R. Cohen, “Israel’s Starry-Eyed Foreign Policy.” 
The Bible became a guidebook, taught by reference to the landscape, less for its humanistic and social message - and not at all for its divine authorship There is nothing more romantic and at the same time more "establishment than to be connected in some fashion with this cult. Its priests are the madrichim-guides and youth leaders. An extensive institutional network sustains yedia'at haaretz: research institutes, field schools the Society for the Preservation of Nature in Israel (SPNI), the Jewish National Fund, youth movements, paramilitary units, the army....It is impossible to comprehend the Israeli psyche without appreciating the impact of the cult of moledet. ${ }^{256}$

Many of Israel's secular Zionist founders considered the Bible primarily as a deed of title to Palestine, as did the state's political architect and first Prime Minister, David BenGurion. In his testimony before the Peel Commission in 1937, he declared, "Our right to Palestine derives not from the Mandate or the Balfour Declaration. It preceded them...The Bible is our Mandate. The Bible, which was written by us in our Hebrew language and in this very land,that is our Mandate."257 Amnon Raz-Krakotzkin sees Israeli secular nationalism not as a replacement for the theological version of Israel's founding myth, but as an interpretation of the myth, making the distinction between "secular" and "religious” identities of Jewish Israelis questionable: "They are called 'secular' because they reject or abandon the Halakha, the Jewish law, but the myth that defines the so-called national-secular is itself based on an interpretation of the theological myth...God does not exist but he promised the land to us."258

256. Benvenisti, Conflicts and Contradictions, 19-20.

257. Simon, 236, no. 1.

258. Interview with Amnon Raz-Krakotzkin: "I Feel Responsible for the Victims of Zionism.” Qantara.de: German Dialogue with the Islamic World website, August 13, 2004. http://www.qantara.de/webcom/show_article.php/_c-476/_nr-206/_p-1/i.html (accessed Oct. 15, 2007). 
One of the primary goals of Israel's Zionist political culture has been "to make the continuity of the ancient past with the contemporary context a taken-for-granted reality." 259 The assumption and assertion of the geographical, historical, and ethnological continuity between the modern State of Israel and the biblical Israelite polity established in ancient Canaan more than three millennia ago-promised by God to Abraham, conquered by Joshua, ruled by David and Solomon, reclaimed by the heirs of the Hasmoneans-became the foundation of the Israeli "master commemorative narrative.”

The establishment of the State of Israel represented the return of the Jewish nation not as a colonial settlement on foreign territory, but a return to its biblically promised ancient homeland from which it had been twice exiled-first by the Babylonians in 586 BCE, and again by the Romans after the Bar Kochba revolt in 135 CE. The modern state of Israel's continuity with its ancient forebearer stands in marked contrast to the surrounding "new" and artificial Middle Eastern states, whose peoples had no real historical connection or attachment to the land, and therefore only a tenuous and transient claim to legitimacy.

The Israeli Foreign Ministry's website illustrates this by offering numerous maps from various historical periods that emphasize the continuity between the present state and its ancient antecedents. One, referenced to I Kings 4:24 in the Bible, sketches the maximal boundaries of the antecedent Jewish state during the time of David and Solomon

259. Myron J. Aronoff, "Myths, Symbols, and Rituals of the Emerging State.” New Perspectives on Israeli History: The Early Years of the State, ed. Laurence J. Silberstein (New York: New York University Press, 1991), 175. 
(1077-997 BCE), encompassing present-day Jordan, extending into Lebanon and the Sinai peninsula, and stretching into Syria far beyond Damascus to the Euphrates River. The second, a rendition of Herod's post-biblical kingdom, 30 BCE to 70 CE, includes Jericho and the Golan Heights, which, the caption notes, was a gift from Caesar Augustus to the Judean king Herod as a reward for his loyalty. Superimposed on both sketches are the boundaries of the present State of Israel, including the West Bank and Gaza.

As Biale notes, the builders of the early Zionist state invoked the collective memory of the biblical Israelite state as a unified, fully autonomous polity that could serve as a model for constructing a sovereign, western European-style nation-state that embodied nineteenth century European concepts of state sovereignty. "The real character of the biblical state—disunited and externally dominated for most of its existence—plays no role in this memory." ${ }^{260}$ According to the Bible, after the division of Solomon's realm, the Israelite kingdoms Judah and Israel each formulated distinct foreign policies and even went to war with one another. The northern kingdom of Israel was overrun by Assyria in 722 BCE, and its population was deported to various regions of the Assyrian empire, which at that point still included much of what would become Persia and Media. Judah, further to the south, retained its sovereignty for another century. During that period, incessant internal struggles between polytheists and henotheists, ${ }^{261}$ between

260. Biale, Power and Powerlessness, 148-149.

261. See Seth Schwartz, Imperialism and Jewish Society, 200 BCE to 640 CE (Princeton: Princeton University Press, 2001), 19-20: "I assume that the Israelite religion, as practiced before the destruction of the kingdom of Judah by the Babylonians in 586 BCE, was distinct from the religion practiced by the Israelites' putative descendants, the Jews, in the Second Temple 
"accomodationists" and "nationalists,"262 and between those Judean political Realists who favored alliance with Egypt against the rising power of Babylon, and those who counseled submission to the Babylon, characterized Judean politics.

Geopolitically sandwiched on the perpetual fault line between one major imperial power to the north (Aram, Assyria, Babylonia, Persia, Greece, Rome) and another to the southwest (Egypt), and strategically situated at the continental confluence of Asia, Africa, and Europe, with the Mediterranean Sea to the west and the waterways abutting the Arabian peninsula to the east, the small Israelite polity of the first millennium BCE almost always found itself on the fault lines of imperial expansion from every direction. The political status of the ancient Jewish polity throughout most of antiquity, Biale emphasizes, was not national sovereignty, but rather a partial and very tenuous independence in an imperial world. ${ }^{263}$ Israel's secular Zionist narrative and its religious version both "forget” that the Bible itself provides scant evidence of an extended golden age of Jewish power in antiquity, nostalgically glorified in liturgy and legend.

period. The Israelites, to be sure, worshiped Yahweh, whose cult was then, as later, centered in Jerusalem, and they seem to have shared many other practices with the Jews. For example, males seem to have been circumcised, pigs were rarely consumed, and mourning rituals seem to have included fasting, sackcloth and ashes. But on the whole, except for brief period of pietistic reform, most Israelites were not henotheists, and they may not have known of many characteristic biblical observances, such as the festivals of Passover and Sukkot, allegedly instituted either by the reformist king Josiah (reigned 609-639 B.C.E.), shortly before the Babylonian conquest or by Ezra and Nehemiah, in the fifth century. And their rituals seem often to have included practices forbidden by the Pentateuch, such as skin cutting, a mourning custom. Most importantly, perhaps, there is no evidence that the Israelites possessed a single authoritative "Torah" that bore any resemblance to the Pentateuch."

262. Biale, Power and Powerlessness, 16.

263, Biale, Power and Powerlessness, 11. 
Under the ancient imperial system, small nations had generally been permitted to govern themselves internally under kings, priests or ethnarchs, who were given a relatively high degree of autonomy, provided that they paid the required tribute to the dominant hegemonic power and did not attempt to rebel against its authority. Rebellion against the dominant power took the form of refusal to pay taxes or tribute. The Bible records that the results of these rebellions were usually disastrous, and the "true prophets" of Yahweh invariably advised against them. During periods of imperial decline, hegemonic transition, and disputes over succession, a greater exercise of sovereignty and territorial expansion was possible. The period of political transition from Egyptian to Syrian (Aramean) dominance in the tenth century BCE, for example, allowed the kingdom of David and Solomon to negotiate political arrangements with surrounding peoples through diplomacy, alliance (frequently effected through marriage), or war. In the latter half of the second century BCE, the hegemonic transition from Seleucid to Roman dominance enabled the Hasmonean dynasty of Judea to expand and establish Judea as a regional power.

The biblical books of Kings and Chronicles provide ample testimony that even the Davidic and Solomonic state at the pinnacle of Israelite power, idealized by Zionist visionaries, was characterized by internal dissent, political intrigue, heterodoxy, religious pluralism, and rebellion. Rivalry between north and south, reifying older traditions of inter-tribal animosities attested to in the Book of Judges, consistently jeopardized the formation and maintenance of a unified Israelite political entity, even under the most 
fortuitous of geopolitical circumstances. After the death of Solomon, popular discontent and longstanding political rivalry culminated in the division of the kingdom of David and Solomon into two mini-states, Judah and Israel (the latter often referred to as "Ephraim," the dominant tribe in the region, or "Samaria," the capital city).

Presumption of the geographical, historical, and ethnological continuity between the ancient polity of the Bible and the modern State of Israel underlies political discourse justifying present-day Israeli territorial rights. Various biblical depictions of the divinely mandated boundaries of the biblical Land of Israel differ in both their extent and specificity. The nomadic patriarchs move about almost exclusively within the region west of the Jordan, for the most part between Hebron and Beersheba. They interact positively with local tribal leaders and conclude treaties with them. The land promised to the "seed of Abraham" is broadly situated geographically as being between the Euphrates River and the "river of Egypt," and is ethnographically specified as the land of the Kenites, Kenizzites, Kadmonites, Hittites, Perizzites, Rephaim, Amorites, Canaanites, Girgashites, and Jebusites (Gen. 15:18-21). ${ }^{264}$ The promise to Abraham that his "seed" would inherit the land, before he had fathered any children, would seemingly have included not only Isaac but Ishmael, as well as his numerous descendants through Keturah, enumerated in Genesis 25:2-4. However, by linking the promise of the land to Abraham's seed to the assertion in Genesis 25:5 that "Abraham gave all that he had to Isaac," biblical

264. See Moshe Weinfeld, The Promise of the Land: The Inheritance of the Land of Canaan by the Israelites (Berkeley: University of California Press, 1993) for explication of these boundaries. 
commentators were able to exegetically override the territorial claims of any other “Abrahamic” descendants.

In Numbers 34:2-12, the land promised to Abraham's descendants extends eastward from the Great Sea along the northern boundary of the mountains of present-day Lebanon to Mount Hor (Hermon), and stretches northward to Hazar-enan (about midway between modern day Balbeck in Lebanon and present-day Damascus in Syria). The eastern border runs along the Kinneret Sea (Sea of Galilee) and the Jordan River as far as the southern edge of the Dead Sea, and the southernmost boundary stops near Kadesh Barnea, at the beginning of Edom (Idumea), the heritage of the Esau tribes. There is no mention of either the River of Egypt or of the Euphrates. However, as the Israelites prepare to conquer Canaan, the geographical boundaries of the Israelite patrimony begin to shift eastward, with the tribes of Reuben and Gad asking to be allowed to settle east of the Jordan River. As Irving Zeitlin observes, "The pattern of actual conquest failed to correspond with the boundaries of the land of ancient promise.” The tribes find themselves conquering land that had never been promised to the patriarchs-Transjordan.”265 A very different paradigm for relations with the various inhabitants of the land begins to emerge.

In Exodus 23:31, the divinely mandated boundaries of the Land extend from the Sea of Reeds to the Sea of the Philistines, and from the desert to the river. God reiterates to Moses' successor, Joshua, that the borders of the Israelite conquest will span the territory

265. Irving M. Zeitlin, Ancient Judaism: Biblical Criticism from Max Weber to the Present (Cambridge: Polity Press, 1984), 126. 
from the desert and the Lebanon to the P'rat River, usually translated as Euphrates, and the Great Sea in the west, encompassing all the land of the Hittites (Joshua 1:2-4). (Jewish commentators disagree as to whether the Hittites referred to here are those which originate in southern Turkey or those further south in Lebanon.) These verses from Joshua also include the admonition that "Every place that the sole of your foot shall tread upon I have given to you,” i.e. anywhere the Israelites transited or occupied, becomes de facto a part of the "Promised Land."

Although the expansive borders of the Davidic-Solomonic kingdom and the Hasmonean state were both short-lived exceptions to the geopolitical boundaries of both biblical Israel and Second Temple Judea, they have remained the discursive backdrop of Israel's "historic" claim to not only to the West Bank and Gaza, but to the Sinai, Lebanon, Jordan, and Syria. From the outset, the founders of the Yishuv, the pre-state infrastructure of what became the State of Israel in 1948, looked at the chronographic as well as the territorial ambiguity of ancient Israel's borders, as depicted in the Bible, as an asset, rather than as a liability. During the armistice negotiations in 1949, Israel's political architect, David Ben-Gurion, told his aides, "In the Bible as well as our history, there are all kinds of definitions of our country's borders, so there's no real limit. No border is absolute. If it's a desert—it could just as well be the other side. If it's a sea, it could also be across the sea."266 Vladimir Jabotinsky (1880-1940), the ideological mentor of Israel’s first Likud Prime Minister, Menachem Begin, and the Revisionist movement,

266. Quoted in Tom Segev, 1949: The First Israelis, English language ed. Arlen Neil Weinstein (New York: Henry Holt, 1998), 6. 
wanted a Jewish state not necessarily as it was promised to Abraham, but inclusive of all the territories controlled in the past by Jews," including substantial parts of Transjordan. $^{267}$

Right-wing territorial maximalists, past and present, have openly advocated annexing these regions to the State of Israel when the opportunity arises, and have vehemently opposed Israeli withdrawal from those that are already under Israeli control. The agenda of the Manhigut Yehudit (“Jewish Leadership”) movement, which became a faction of the Likud party in 2000 at the invitation of party leader Benjamin Netanyahu, declares, "A law will be passed for the restoration of lands-the main essence of which will be that all land that is conquered, acquired or held by Jews within the Biblical boundaries of the Land of Israel shall immediately become an indivisible part of the State of Israel.”268 They contend that Israel has already relinquished much of its divinely promised biblical patrimony to Jordan, Lebanon, and Syria, and the territories conquered during the 1967 war may never be relinquished. The Gush Emunim movement and its successors used religious law to justify illegal settlement activity immediately after the war, much of which subsequently received de facto recognition from the Israel government:

267. Ilan Peleg, Begin’s Foreign Policy, 1977-1983: Israel's Move to the Right (New York: Greenwood Press. 1987), 12.

268. "Jewish Identity for the Jewish State: An Overview” by Manhigut Yehudit leader Moshe Feiglin. http://www.jewishisrael.org/jewish_state/overview.htm\#Sovereignty (accessed Oct. 15, 2007). According to Feiglin, who received a quarter of the vote in the Likud primary in mid-August 2007, "The results show a great momentum towards a faith-based leadership.” Hillel Fendel, "Netanyahu, Following Election Landslide, Still Scared of Feiglin,” Israel National News, August 15, 2007. http://www.israelnationalnews.com/News/News.aspx/123387 (accessed Aug. 25, 2007). 
For Gush Emunim, the basic notion of "Greater Israel" as constituting the "promised land" is essentially a religious one. For the national religious community, territorial withdrawal and settlement evacuation is in direct contradiction to the law of the Torah, which takes precedence over any form of human decision making process, however democratic that process may be. As such, the West Bank Rabbis Forum (Yesha [Rabbis]) has become the most important ideological forum, to which the political leadership have become increasingly subservient. The Yesha Rabbis have issued public statements that governmental decisions which negate the Greater Land of Israel ideology are in contradiction to Torah law and are therefore "immoral" and not to be observed. As the national religious population has become increasingly fundamentalist in matters of religious observance and ritual in the past two decades, so too the Rabbis have greater influence over the political activities and decisions of the settlers themselves. $^{269}$

The Bible is also invoked in Israeli political discourse emphasize the continuity between the enemies of the biblical Israelites and those of today's Israelis, with whom conflict is both inevitable and perpetual. "The Realpolitik assumption that yesterday's enemy is tomorrow's potential friend flies in the face of the Jewish image of an implacable enmity between Israel and its eternal foes,” observes Raymond Cohen. “Israel’s leaders have inherited an entire vocabulary and set of metaphors from Biblical and especially Rabbinic sources to describe and prescribe relations with 'the nations' (goyim).” Israel's political isolation and near-pariah status in the United Nations reinforce, and are reinforced by, the biblical image of "a people that dwells alone" (Numbers 23:9). ${ }^{270}$

269. David Newman, From Hitnachalut to Hitnatkut: The Impact of Gush Emunim and the Settlement Movement on Israeli Politics and Society. Israel Studies 10.3 (2005) 195-196.

270. R. Cohen, “Israel’s Starry-Eyed Foreign Policy.” 
Although the Bible recognizes the kinship between the Hebrews and neighboring peoples, such as the Ishmaelites, who were descended from Abraham through Sarah's slave Hagar, the Hebrews are unwilling to share their land with them. Abraham, designated in the book of Genesis as "the Hebrew," is the father of Ishmael and of Isaac. Sarah demands that Ishmael be disinherited when Isaac is born, and, as Ze'ev Falk points out, God Himself appears to share this exclusive attitude (Gen. 21:12). The figures of Isaac's son, Esau, and Esau's grandson Amalek, represent a quintessential example of the use of a biblical motif to define relationships with enemies in Israeli political discourse. Isaac and his wife Rebecca have twin sons, Jacob and Esau. While she was pregnant, Rebecca was told that the struggle between the twins in her womb that she could feel during her pregnancy presaged the conflicts between the nations descended from them. Years later, Jacob manipulates Esau into selling him his birthright, and, with Rebecca's help, tricks his blind father into giving him the blessing intended for Esau. It was for this reason, according to the Bible, that "Esau hated Jacob for the blessing with which he was blessed by his father” (Gen. 27:41).

After the Hebrew slaves leave Egypt, they are referred to in the biblical books of Exodus, Leviticus, Numbers, and Deuteronomy as B'nai Yisrael (sons or children of Israel), or occasionally as Beit Yaakov (the house of Jacob). ${ }^{271}$ Jacob (Yaakov), whose name is later changed by an angel to "Israel" (Yisrael), is the symbol of the Jew in rabbinic literature, while his twin brother, Esau, represents the non-Jew and the

271. Medieval and modern bible commentators often deal with the distinction in the use of the two terms by interpreting Beit Yaakov as the women of the Israelite community. 
archetypal anti-Semite in traditional Jewish legend and commentary (midrash). Jewish legend identified Esau, who had emerged from the birth canal red (adom) and hairy, and was therefore also called Edom, with the empire of Rome, and eventually with Christianity. According to Pinchas Peli, "Both are of the same race and the same breed, children of the same mother and father, and yet representing contrasting worlds. Their juxtaposition is not a one-time affair or an antiquated myth; it is enacted and re-enacted anew every day. Any attempt at an understanding of what one may call by extension Anti-Semitism must take into account the primal Jacob-Esau encounter."272

The region of Edom (Idumea), which, as noted above, was not within the biblical boundaries of the Land of Israel, was forcibly Judaized during the Hasmonean conquests during the mid-second century BCE. During the civil war between the grandsons of the Hasmonean John Hyrcanus, Antipater, the Idumean (Edomite) father of Herod "the Great,” intervened on behalf of Hyrcanus, inviting Roman intervention, and successfully gaining Roman support for Antipater's own dynastic aspirations. After the death of Antipater's son Herod, Roman procurators ruled Judea directly on behalf of the Roman Empire, eventually destroying the Jerusalem Temple in 70 CE. The imputed historiographical and allegorical reference to "Edom" served not only to connect the biblical Esau with the Romans, but, more significantly, to reinforce the continuity between the biblical Esau's inferred hatred for his brother Jacob with subsequent manifestations of anti-Semitism throughout the ages. According to the medieval

272. Pinchas HaCohen Peli, "Responses to Anti-Semitism in Midrashic Literature.” In Anti-Semitism in Times of Crisis, eds.. Sander Gillman and Steven T. Katz (New York: New York University Press, 1991), 107. 
commentator Nachmanides, "in my opinion...we initiated our downfall through the hand of Edom. For the kings of the Second Temple [i.e. the Hasmoneans] entered into a treaty with Rome."273

As Liebman and Don-Yehiya explain, the main line of Jewish tradition considered anti-Semitism to be normative, and the natural response of non-Jews to Jews. It was the absence of hostility toward the Jew—i.e. anti-Semitism—-that required explanation:

Esau hates Jacob symbolized the world the Jews experienced. It is deeply embedded in the Jewish folk tradition. Its resonance, however, rests on the fact that it not only reflects Jewish experience but, at the same time, it avoids a direct statement about non-Jews' feelings toward Jews. Such a statement, something like 'all non-Jews hate Jews,' would be not only offensive to non-Jews but clearly incorrect...But the allegory of Esau and Jacob evokes a sense of reality that functions to maintain a boundary around Jews and cement Jewish unity. ${ }^{274}$

The treatment of Esau in medieval Jewish sources was not uniformly negative. According to Maimonides, Esau, although an evildoer, was rewarded for honoring his father. Although the descendants of his grandson Amalek were doomed to extinction, some descendants of Esau would remain in Edom as Israel's neighbors, while others would eventually achieve greatness through Rome and then through the Catholic Church. ${ }^{275}$ However, such nuances have largely been lost in the use of Esau vs. Jacob in

273. Cited in Amos Funkenstein, Perceptions of Jewish History (Berkeley, Los Angeles and Oxford: University of California P, 1993), 110-111.

274. Liebman and Don-Yehiya 138-139.

275. Salo W. Baron, . “The Historical Outlook of Maimonides.” Proceedings of the American Academy for Jewish Research VI (1935)., 5-133, reprinted in History and Jewish Historians: Essays and Addresses by Salo W. Baron, compiled with a foreward by Arthur Hertzberg and Leon A. Feldman (Philadelphia: Jewish Publication Society, 1964), 119. 
Israeli political discourse, as they become internalized and associated with present-day politics, irrespective of religious context and observance. "I believe in one thing: that Esau hates Jacob,” an Israeli military commander stated in a newspaper interview. ${ }^{276}$

The eternal hatred of the Jewish people is also carried out through Esau's grandson Amalek, who is reincarnated into the enemies of the Jewish people in every generation. Although the Book of Genesis refers to the existence of Amalekites even in the time of the patriarch Abraham (Genesis 14:1-12), ${ }^{277}$ Amalek, the eponymous ancestor of the Amalekites, was Abraham's great-great grandson, according to the genealogy of the Esau tribes in Genesis (Genesis 36:12). Two passages in the Bible deal with the source of eternal enmity between the descendants of Amalek and the Israelites fleeing their enslavement in Egypt. During an unexplained and apparently unprovoked attack by the Amalekites on the Israelite camp at Rephidim, Moses enables the Israelites to prevail by holding up the rod of God. God then tells Moses to write out a document as a reminder that He "will utterly blot out the name of Amalek from under heaven, whereupon Moses declares, “The Lord will be at war with Amalek throughout the ages” (Ex. 17:8-13).

Another biblical passage concerning Amalek is found in a retrospective account of the Israelite sojourn in the desert that Moses delivered to the Israelites before he died, as they prepared to enter Canaan and conquer it. Moses instructed the Israelites:

276. Maariv, August 22, 1980, cited by Liebman and Don-Yehiya 141.

277. During the War of the Kings, in which Abraham takes participates in order to rescue his abducted nephew Lot, the Amalekites are also victims of the invasion led by the Elamite king Chedorlaomer . 
Remember what Amalek did to you when you left Egypt-how, undeterred by fear of God, he surprised you on the march, when you were famished and weary, and cut down all the stragglers in the rear. Therefore, when the Lord your God grants you safety from all your enemies around you, in the land that the Lord your God is giving you as a heritage, you shall blot out the memory of Amalek from under heaven. Do not forget! (Deut. 25:17-19).

The command appears to be, according to Louis Feldman, a directive to the Israelites "to return Amalek to a state of non-existence, i.e., Amalek is to be drummed out of the world order."278

"Jews have a tendency to seek out the latest embodiment of Amalek, the nefarious enemy of the tribes of Jacob who, according to legend, arises in every generation to attempt to carry out his satanic mission,” observes Raymond Cohen. ${ }^{279}$ The biblical Amalek evolved in medieval rabbinic commentary from a hereditary distinction or ethnicity to a categorical behavioral paradigm, which facilitated the designation of specific persons or groups as a manifestation of Amalek. In medieval Europe, Jews referred to Christians as Amalekites, ${ }^{280}$ while the uses of Amalek as a Hebrew term for

278. The historical evolution and multifaceted Jewish understandings of the "genocidal commandment" to eliminate all Amalekites-men, women and children-- as well as a survey of the literature discussing the moral and ethical problems raised by this seemingly unequivocal Divine imperative to consign a particular people to oblivion has been dealt with in depth by Feldman. See Louis H. Feldman, "Remember Amalek!”: Vengeance, Zealotry and Group Destruction in the Bible According to Philo, Pseudo-Philo, and Josephus (Cincinnati, Hebrew Union College Press, 2004), 10.

279. R. Cohen. Israel’s Starry Eyed Foreign Policy.”

280. Eugene Korn, “Moralization in Jewish Law: Genocide, Divine Commands, and Rabbinic Reasoning,” Edah Journal 5, no. 2, Sivan 2006, 11. http://www.edah.org/backend/JournalArticle/KORN_5_2.pdf, (accessed Feb. 3, 2007), 11. 
"Armenian" dates back to the author of Yossipon in the tenth century and was still in use in among Jews in Galicia, Georgia, and Greece in the $19^{\text {th }}$ century. ${ }^{281}$

In the twentieth century, Amalek and his descendants continue to represent the archetypal lineage of all enemies of the Jewish people and, by extension, of the modern Jewish state. During the Nazi era, Rabbi Moses Soloveitchik extended the designation of Amalek to any person who attempted to destroy the Jewish people. "There is no doubt about it. Hitler was Amalek. I am speaking in halakhic terms. Hitler and his entourage were Amalek...the incarnation of total evil." ${ }^{282}$ His son, Rabbi Joseph Soloveitchik (1903-1993), labeled as “Amalek" the Arabs attempting to eliminate Israel in the 1950s, while excluding innocent "Amalekite" women and children from the application of the command to expunge the name of Amalek. ${ }^{283}$ The epithet of Amalek was subsequently directed against Arab states opposed to Israel's existence, Palestinian suicide bombers, and to Arabs in general, including civilians. Israeli legal scholar Amnon Rubinstein, a longtime advocate of a secular, humanistic Zionism that grants full equality for Arabs in Israel, decries the application of biblical and halakhic directives to the modern State of Israel's security dilemmas:

The Deuteronomy injunction to smite Amalek and 'blot out his memory' is taken, despite all religious evidence to the contrary, as referring to the Arabs. Consequently, and because Israel's wars are described a "war of religious obligation," ordinary rules of humanity should not be applicable to these new

281. Elliott Horowitz, Reckless Rites: Purim and the Legacy of Jewish Violence (Princeton: Princeton University Press, 2006), 124.

282. Aaron Rakeffet-Rothkoff and Joseph Epstein, eds. The Rav: the World of Rabbi Joseph B. Soloveitchik (New York: Ktav, 1999), 152-153.

283. Korn, 11. For J. Soloveitchik's ruling that there is no obligation to kill noncomplicit Arab women and children, See 9, n.36. 
"Amalekites.”...Military chaplains have scandalized the public by asserting that under Halachic law, Arab civilians may be killed in these wars of religious obligation. $^{284}$

The Hebrew Bible contains one book that, more than any other, has been interpreted as paradigmatic of the Jewish historical encounter with Amalek. One of the last books added to the Hebrew Bible: ${ }^{285}$ the Scroll of Esther (Megillat Esther, often referred to as the "Book of Esther") is a gripping novella with sex, violence, intrigue at the highest echelons of government, and a happy ending. It is the only book of the Bible in which God is never mentioned. Numerous biblical and classical scholars, Jewish and non-Jewish, consider the Scroll of Esther as a Hellenistic novel dealing with the Seleucid period, rather than a historical account of any events that took place in Achaemenid Persia.

From a literary perspective, the style of the work is straightforward, even “journalistic” (and very un-Persian in the sort of details recorded). Queen Vashti, wife of King Ahasueros, refuses to obey her husband's order to present herself at an all-male party he is hosting, at which a profusion of alcohol was being served, in order to show off her beauty. The king's advisors convince him that the queen's disobedience will set a bad example for the women of the empire, and that he must therefore get rid of her. Ahasueros reluctantly agrees, but he soon regrets his decision. To console him, his chief courtiers persuade him to gather together the most attractive maidens of his empire and to

284. Amnon Rubinstein, The Zionist Dream Revisited: From Herzl to Gush Emunim and Back (New York: Schocken Books, 1984), 116.

285. Scholars disagree as to whether Daniel or Esther was the last book added to the Hebrew Bible. Most agree that both are Hellenistic novels. 
choose Vashti's replacement from among them. In popular renditions of the story of Esther, the process is almost invariably depicted as a beauty pageant in which attractive women competed to become part of the king's harem, although the text of the novella is ambiguous about the process by which the massive roundup of thousands of beautiful women from the vast borders of the Persian empire took place. Among them is Esther, a young woman whose deceased parents were descended from Judean exiles.

Once in the king's harem, the women are under the supervision of the palace eunuchs. Each woman receives an entire year of cosmetic treatments-described in detail—to prepare her for a single night with the king, after which she moves to another women's house within the palace where she remains for the rest of her life, never again called to the king unless he specifically requests her by name. Reminiscent of the Arabian Nights, Ahasueros avails himself of one virgin after another until at last, after three years, he spends the night with Esther. Smitten with her beauty and charm, he crowns her queen in place of Vashti.

Esther does not reveal her ethnicity to anyone in the palace on the advice of her uncle/cousin Mordechai, who cared for her after the death of her parents. ${ }^{286}$ One of the literary devices upon which the plot of the story depends is the fact that, although Esther maintains constant contact via messengers with Mordechai, who is well known to all the functionaries and courtiers within the palace complex as Mordechai ha-Yehudi

286. According to the Babylonian Talmud (Megilla 13a) and some subsequent rabbinic traditions, Esther and Mordechai were married. For a discussion of some of the textual and moral problems arising from this assertion, see Nosson Scherman, "An Overview--The Period and the Miracle” in The Megillah: The Book of Esther, translated and compiled by Meir Zlotowitz (Brooklyn, NY: Mesorah Publications, 1989), xxxi-xxiii. 
(Mordechai the Judean, usually translated as Mordechai the Jew), for five years, no one in the palace even suspects that Esther is of Judean/Jewish ancestry. When Haman, the king's vizier, devises a genocidal plot to destroy all of the Yehudim of the empire and Esther, at the risk of her own life, intervenes, revealing Haman's plot to be an attack on her and her people.

While the Persian king is powerless to rescind a command promulgated by Haman for the destruction of the Jews by Haman with his own signet ring and with his permission, Ahasueros authorizes Esther to take his ring and do whatever she sees fit to save her people. Mordechai dictates an edict to the royal scribes that authorizes the Judeans throughout the empire to defend themselves from attackers and avenge themselves on anyone who carried out Haman's instructions by killing them and plundering their property. According to the "happy ending," thousands of Persians who obeyed Haman's decree to attack the Jews and plunder their property, even after it had been countermanded by a decree from Esther that Jews would be permitted to defend themselves, were slaughtered by the Jews. (There is no mention of any such massacre of Persians by Jews in Persian or Babylonian tradition.)

Haman is "the son of Hammedata the Agagite," which, according to rabbinic exegesis, identifies him as a descendant of Agag, the Amalekite king during the reign of King Saul (I Samuel 15:9). Haman represents the Amalekite determination to exterminate the entire Jewish people, while Mordechai, in bringing about Haman's downfall, does what his own ancestor, Saul, had refused to do-to follow God's 
command to wage war on Amalek and kill him, showing no mercy. ${ }^{287}$ The Book of Esther provides the historiographic framework for the "collective memory" of life in Persia within Jewish historiography throughout the ages. In the process, Haman, who, according to rabbinic interpretation, is descended from Amalek and shared his genocidal intentions towards the Jews, largely overshadows and overwrites the more benevolent biblical traditions associated with Cyrus. This is also used to define the current IsraeliIranian relationship, with Haman representing Iran.

As Adele Berlin observes, "Very few twentieth-century Bible scholars believed in the historicity of the book of Esther, but they certainly expended a lot of effort justifying their position.”288 According to Robert Littman, “Whatever one’s judgment about the origins of Purim...it is agreed that the Book of Esther has a historical setting in the reign of Xerxes and it is replete with details of Persian court life.” ${ }^{289}$ Elias Bickerman contends that the author of Esther was probably a Jew from Susa, writing sometime in the second century BCE, and definitely before 78/77 BCE (the date of Greek Esther), who combined two popular folk motifs in order to explain a festival observed by the Jews of

287. Scherman, op. cit, xxviii-xxx.

288. Adele Berlin, "The Book of Esther and Ancient Storytelling,” Journal of Biblical Literature 120/121 (2001), 3. Berlin provides a very helpful literature review regarding the debates over the historicity of Esther, as does Robert J. Littman, “The Religious Policy of Xerxes and the 'Book of Esther,” The Jewish Quarterly Review, new series 65, no. 3 (January 1975), 145-155.

289. Littman, Ibid., 148. Although it does not mention the story of Esther or the biblical book, some fresh and pertinent points for an in-depth assessment of the accuracy of Esther's depiction of women in Persian court life can be found in Maria Brosius' Women in Ancient Persia 559-331 BC (Oxford: Clarendon Press, 2002). 
Susa on the $15^{\text {th }}$ of Adar, but observed by other Jews in the countryside on the $14^{\text {th }}$. Bickerman believes the author wanted to make this local feast into one that is recognized and voluntarily observed by all Jews, in much the same way that the Hasmoneans in Maccabees II invited the Jews of Alexandria to observe the festival of the restoration of the Jerusalem sanctuary. ${ }^{290}$

Theodor Gaster suggests that "Purim may have originally been the Persian New Year festival [noruz] held at the time of the vernal equinox and characterized by all the rites and ceremonies associated with that occasion,” pointing out that Purim frequently falls within a week of the vernal equinox. ${ }^{291}$ Although the story purports to be one about Jews and explaining a Jewish festival, "every detail of its Jewish coloration involves something either anomalous or incredible,” from the non-Jewish names of the hero and heroine, to the chronological implausibility of Mordechai having been one of the original deportees from Jerusalem to Babylon 112 years earlier, and Esther's having been the consort of a Persian king, which Gaster says, in light of Persian custom, can only be considered "bizarre."292 Furthermore, Gaster notes that the word pur (lot) from which

290. Elias Bickerman, Four Strange Books of the Bible (New York: Schocken Books, 1967), 202-203.

291. Theodor Herzl Gaster, Purim and Hanuukkah in Custom and Tradition (New York: Henry Schuman, 1950), 17-18.

292. Gaster, Ibid. 33. More specifically, Brosius points out that "Marriage alliances were political acts. Interfamilial alliances between the Achaemenid kings and the Persian nobles were politically motivated, as the reward for military merit, in acknowledgement of proven loyalty to the king, and as gift-exchange.” The marriages of royal sons and daughters also played a significant role in domestic and foreign policy. Brosius argues that the early Achaemenid kings, at a time that the Persian empire was expanding, utilized marriage to foster and sustain political alliances with Near Eastern rulers outside the empire. Once the power of the empire was consolidated, the emphasis shifted on assuring the loyalty of the most powerful Persian families, 
the festival allegedly derives its name, exists neither in Hebrew or Aramaic, the two languages spoken by the Jews. ${ }^{293}$

That the Book of Esther is set in the reign of Xerxes, who was heavily committed to Zoroastrianism of an orthodox variety, is neither a coincidence nor an accident. The historical Xerxes reversed the practice of religious tolerance of his predecessors. Darius had followed a policy of funding temples throughout the realm, including Jerusalem, while Xerxes, says Berquist, radically changed Darius’ policy, withholding construction and operation funds from temples, and destroying them in some places in order to curb temple-centered nationalist movements. "The destruction of temples was not so much a religious act as a political act to remove the base of power for rebels and nationalistic feeling and organization that these rebels could foster." ${ }^{\text {294 }}$ After a Babylonian revolt in 482 BCE, the Persian general Megabyzus, Xerxes’ brother-in law, took firm control of Babylon and melted down the 18 foot high, $800 \mathrm{lb}$. solid gold statue of Bel Marduk into bullion. ${ }^{295}$ Littman contends that the victims of Xerxes I in the

and foreign women were limited to the status of concubines. Brosius, 191-196. That a woman whose family origins were unknown, Judean or not, would be granted the status of queen seems to defy possibility. The biblical Esther, if she existed, could not have been more than a concubine.

293. Gaster, Ibid. 33.

294. Berquist, 89.

295. Berquist, 88. 
original story upon which the biblical Book of Esther is based were not Jews, but Babylonians who worshipped Marduk and Ishtar. ${ }^{296}$

Ironically, it was the staunch and uncompromising monotheism promoted by Xerxes to squelch nationalist movements that resulted in his villainous reputation in Jewish folk literature. From a religious perspective, Xerxes had done precisely what the Hebrew prophets had hoped Cyrus would do-he had cut off support for the numerous shrines and cults of Babylon and, in some cases, destroying them-although he did so in the name of Ahura Mazda, rather than Yahweh. The consequence of this monotheistic policy was the reduction or elimination of state financing of other non-Zoroastrian shrines, including the Jerusalem temple. There is no record in biblical or Persian sources of a Judean rebellion under Achaemenid rule (unlike the revolts that took place after the Babylonian conquest and would take place in the first century CE under Roman rule), and, correspondingly, no reference to any destruction or damage done to the Jerusalem temple. However, Berquist observes, “it does appear that Yehud's temple suffered a radical decrease in funding, and thus the temple experienced a protracted time of financial problems,” one of the themes of the biblical Book of Malachi. ${ }^{297}$

The power and popularity of the Purim legend would seem to derive in good measure from the opportunity to celebrate a holiday, most likely of foreign derivation that had none of the prohibitions applicable on the biblically mandated festivals. The celebration of Purim not only permitted, but encouraged levity, and allowed for lifting

296. Littman, 152.

297. Berquist, 89. 
normal restrictions on feasting and drinking to the point of inebriation, gambling, and levity, coupled with the drowning out of the name of Haman (Amalek) during the ritual reading of the Scroll of Esther in the synagogue, and the custom of festive theatrical reenactments (purimspiels) of biblical events.

The custom of burning Haman in effigy on Purim was common to many Jewish communities in the early centuries of the Common Era and during the geonic period in Babylonia. $^{298}$ It was banned by the Church and abandoned by Jews in Christian Europe because of accusations that the hanging, crucifying, and burning of Haman was a symbolic crucifixion of Jesus. $^{299}$ In predominantly Muslim countries, however, the practice continued well into the twentieth century. In Iran, children traditionally prepared a large effigy of Haman, and filled its clothes with gunpowder. They set up a large stick in the middle of the courtyard, from which Haman was hung. After throwing oil over the effigy, they would set it alight. ${ }^{300}$ Similar Purim rituals that burn Haman in effigy have also been recorded in various Jewish communities in Yemen, Bukhara, the

298. "The Ge'onim explained the custom, mashvarta dePurim, as follows: The young lads make an effigy of Haman and hang it from the roofs for four or five days. Then, on Purim, they make a bonfire and throw the effigy into it, and they dance around the fire and sing. They hang a ring over the fire, and they jump through the ring from one side of the fire to the other. " Yom-Tov Lewinsky, Ketsad hiku et Haman i-tefutsot Yisrael : yalkut folklori le-Furim ("Hamansmiting in the diaspora”), (Tel-Aviv, Hevrah ha-ivrit le-Yeda-am, 1947).

299. Lewinsky, Ibid.

300. Loolwa Khazzoom, "Purim Middle Eastern Style: Setting the Night on Fire.” Generation J.

Com archive. http://www.generationj.com/archive/03_2001/purim_middle_eastern.html (accessed July 14, 2004). 
Caucasus, Tunisia, and Libya. ${ }^{301}$ The Jews of southern India were also familiar with custom of burning Haman as part of the celebration of Purim. ${ }^{302}$

The events found in the Scroll of Esther have been also been marked in other ways. The medieval traveler. Benjamin of Tudela, attested to a longstanding tradition of the Jews of Persia of making pilgrimages to Hamadan, the ancient city of Ecbatana, where Esther and Mordechai were said to be buried. ${ }^{303}$ From medieval to modern times, Jewish communities, vulnerable to persecution, have commemorated deliverance from danger as a "second Purim.” Yosef Hayim Yerushalmi identifies several local Purim reenactments (Granada 1038; Narbonne 1236; Syracuse 1380 or 1420; Morocco 1497; Cairo 1520; Tangier 1844; and unspecified nineteenth century events during the Napoleonic Wars), and points out that they shared certain common features.

Local in character, the observance of this local Purim commemoration was limited to a specific geographic area. A "scroll” narrating the event, modeled on the style and structure of the Scroll of Esther, was composed and read. "For all of them the original Purim served as a paradigm, and the new events were interpreted according.”304

301. Ora Limor and Haya Shenhav, A Purim Anthology. Department for Jewish Education and Culture in the Diaspora, http://www.jajz-ed.org.il/festivls/purim/pugnen07.html (accessed June 12, 2000).

302. My thanks to Dr. Arthur M. Lesley of Baltimore Hebrew University for this information (e-mail correspondence April 15, 1999).

303. Benjamin of Tudela, The Itinerary of Benjamin of Tudela: Travels in the Middle Ages (Malibu, CA: Joseph Simon/Pangloss Press, 1987), 113.

304. Yosef Hayim Yerushalmi, Zakhor: Jewish History and Memory (Seattle: University of Washington Press, 1983), 46-48; 119. Also see Horowitz, Reckless Rites, 279-315, "Local Purims and the Invention of Tradition.” 
The Jews of Iran proclaimed a holiday they called 'id-i basharat (Festival of Good Tidings) when, in 1629, Shah Safi I, shortly after he ascended the throne, gave royal permission to the Jews of Isfahan, who had been forced to convert, to return to Judaism. The festival was celebrated annually on the date of their deliverance as a sort of local Purim. "In the memory of the community of Isfahan, this deliverance was not less miraculous than that which engendered the Festival of Purim.”305

The period between the sabbath before Purim (Shabbat Zakhor, the "sabbath of memory," when the scriptural reading to exterminate Amalek is read) has also been associated with incidents of violence precipitated by Jews. Jewish settlers made their way into Hebron in 1981 and refused to leave. Provocative incidents subsequently occurred on Purim that deliberately incited Hebron's Arab population. It was on Purim, in 1994, that Baruch Goldstein, a Kiryat Arba settler, shot twenty-nine Muslims as they prostrated themselves at the Tomb of the Patriarchs. ${ }^{306}$ Goldstein was the role model for Yigal Amir, the assassin of Israeli Prime Minister Yitzhak Rabin.

Amalek and Haman provide a conceptual as well as a narrative link between the Bible and what became the defining paradigm for Israeli security and survival—-the European Holocaust. Israel's Declaration of Independence enshrined the assumption that "the Holocaust had proven once again that the only solution to the Jewish problem was an independent state in Israel," while the assumption that "the rest of the world—literally

305. Vera Basch Moreen, Iranian Jewry's Hour of Peril and Heroism : A Study of Babai ibn Lutf's Chronicle (1617-1662) (New York and Jerusalem: American Academy for Jewish Research, 1987), 94.

306. Horowitz, 11-12. 
every nation—was hostile and had nothing to save the Jews during the Holocaust” was embodied in Israeli security discourse and doctrines. ${ }^{307}$ In May, 1967, as the prospects of a war with Egypt loomed in which tens of thousands of Israelis were expected to die, Israel's civilian population was warned that a "second Holocaust" was on the way. Analogies to the European Holocaust were widely credited with mobilizing and motivating Israeli soldiers to prevent the annihilation of the Jewish nation. As one Knesset member put it, "At our sides fought the six million, who whispered the eleventh commandment in our ear, 'Thou shalt not be killed'-the commandment that was omitted at Mount Sinai but given to us now, during the Sinai battles.”308

Paradoxically, Israel's victory and territorial expansion as a result of the Six Day War were accompanied by increased feelings of insecurity and a sense of Israel's isolation in the international community demanding in U.N. Resolution 242 that Israel withdraw to its 1967 boundaries, which also found expression in Holocaust political metaphors. The Jewish fate (ha-goral ha-yehudi) — reified in the tiny State of Israel, encircled by enemies bent on its annihilation, and singled out for condemnation by the nations of the world — was "eternal isolation, unending anti-Semitism, and a continual threat to Jewish survival.” 309

Nurith Gertz, like Biale and Peleg, sees several factors that influenced "the melding together of Jewish and rightist narratives and their penetration into mainstream

307. T. Segev, The Seventh Million, 185.

308. T. Segev, The Seventh Million, 393.

309. Biale, Power and Powerlessness, 159. 
Israeli society.” The trial of Adolf Eichmann opened the previously repressed subject of the Holocaust for public discussion, and introducing its horrors into public discourse to a new generation of Israelis and to the nearly half of Israeli Jews whose roots were in Muslim countries. The Six Day War aroused messianic sentiments as well as anxiety, with the remnant of the Temple in the Old City of Jerusalem and the ancient cities of Hebron, Nablus, and Jericho in Israeli hands. ${ }^{310}$

Israel's Labor party, which had dominated Israeli politics since the founding of the state nearly 30 years earlier, was blamed for Israel's lack of preparedness for the Yom Kippur War of 1973, as well as for ideological bankruptcy. Menachem Begin, who broke the monopoly of Israel's Labor party, served as Israel's Prime Minister between 1977 and 1983. Begin brought grievance to the forefront of Israeli politics with the unprecedented use of Holocaust imagery in domestic and foreign policy. He transformed the European Holocaust into a symbol of the religious persecutions suffered by all Jews, including those from Arab countries, and based his domestic coalition on it. "For Begin, all Jews are united by the hostility of the non-Jewish world, a hostility at once historical and contemporary.”311 The structure of Begin’s speeches, Nurit Gertz observes, "viewed the world as a great wasteland peopled by only two protagonists—-we' and 'they'—who play out the final scene of the familiar drama in which the isolated few triumph over the mighty many.” The struggle, however, is not one of faith, determination, or resourcefulness, but of sheer military might, brought to bear in what was portrayed as "a

310. Nurith Gertz, Myths in Israeli Culture: Captives of a Dream (New York: Schocken Books, 1987), 61 
contest between Israel and the rest of the world, one that can be resolved only through destruction or redemption.” 312

Begin not only based his domestic coalition on identification with the European Holocaust, but he invoked it to justify his foreign policy as well. Since the Holocaust, Begin repeatedly stated that the nations of the world had no right to demand any accountability from Israel for its actions ${ }^{313}$ Launching the invasion of Lebanon, Begin told his cabinet, "Believe me, the alternative is Treblinka, and we have decided that there will be no more Treblinkas.” When an Israeli air strike demolished the Osiraq nuclear facility in Iraq in June 1981, Begin declared, "We must protect our nation, a million and a half of whose children were murdered by the Nazis in the gas chambers." ${ }^{314}$ After the Osiraq raid, which set back, but did not eliminate, the Iraqi nuclear weapons program, Begin and Defense Minister Ariel Sharon asserted the "Begin Doctrine” that Israel would never allow any enemy state (some versions say “Arab state”) to acquire nuclear capability. An unspoken corollary to the "Begin Doctrine” was that any Middle Eastern state that acquired nuclear capability was, de facto, an enemy.

Beyond the facts of what occurred in the European concentration camps, however, the question for Israelis was how to absorb the Shoa (as the Holocaust is

311. Biale, Power and Powerlessness, 156-159.

312. Gertz, 60-61.

313. T. Segev, The Seventh Million, 399.

314. Gideon Alon, "Begin: If Iraq Tries Again to Build a Nuclear Reactor, We Will Act against It.” Haaretz, June 10, 1981, p. 1. 
referred to in Hebrew) into Zionist narrative. “(T)he history of Israel's painful confrontation with the Holocaust is a story of uncertain identity,” according to Tom Segev. “The Israelis' vision of the Holocaust has shaped their idea of themselves, just as their changing sense of self has altered their view of the Holocaust and their understanding of it meaning.”315

After a great silence in the years immediately after the war, suspicions began to be aired about who had survived the death camps, and how. In cases where some Jews were saved but not others, questions arose about the choices of who to save, and why. Accusation of collaboration began to be raised. Debate ensued over establishing diplomatic relations with West Germany and acceptance of reparations by individuals and by the state. "The Holocaust came to be seen as a Jewish defeat. Its victims were censured for having let the Nazis murder them without fighting for their lives or at least the right to 'die with honor,"” an attitude that, Segev says, "became a sort of psychological and political ghost that haunted the State of Israel—reflecting scorn and shame, hubris and dread, injustice and folly.”316 Furthermore, Segev points out:

The most fateful decisions in Israeli history, other than the founding of the state itself - the mass immigration of the 1950s, the Six-Day War, and Israel's nuclear project-were all conceived in the shadow of the Holocaust. Over the years, there were those who distorted the heritage of the Holocaust, making it a bizarre cult of memory, death and kitsch. Others too have used it, toyed with it, traded on it, popularized it. As the Holocaust recedes in time-and into the realm of history-its lessons have moved to the center of a fierce struggle over the politics, ideology, and morals of the present. ${ }^{317}$

315. T. Segev, The Seventh Million, 11.

316. T. Segev, 109.

317. T. Segev, 109. 
One of the ways this memory is maintained is through the observance of Holocaust Day (Yom HaShoa), a week after Passover. The process by which the commemoration day was decided upon reflects the fissures within Israeli political culture at the time. On April 21, 1951, the Knesset declared the $27^{\text {th }}$ day of the Hebrew month of Nissan would be designated "Holocaust and Ghetto Rebellion Memorial Day," since the Warsaw ghetto revolt in Poland had begun on Passover eve. Many of the Warsaw rebellion fighters were affiliated with the youth movement of the left-wing socialist Mapam Party. In 1959, the day was redesignated Holocaust and Heroism Memorial. Day, and two years later, named "Holocaust, Rebellion and Heroism Memorial Day." Flags are flown at half mast. Movies and other entertainment places are closed, although some restaurants and cafes stay open in defiance of the law. Radio and television stations are dedicated to the subject of the Holocaust, as are newspapers. A siren is sounded, and people stop whatever they are doing, including driving, as it blares. ${ }^{318}$

Israeli high school students are required to study a thirty hour curriculum about the Holocaust in eleventh and twelfth grade. The Holocaust is including on their matriculation exams. ${ }^{319}$ Since the mid-1980s, high school students have visited concentration camps in Poland on class trips, often referred to as "pilgrimages". An estimated 24,000 Israeli students visit Poland on these trips each year. ${ }^{320}$

318. T. Segev, 436-439.

319. Marion Marache, Jerusalem Post, April 16, 2001.

320. Task Force for International Cooperation on Holocaust Education, Remembrance and Research. "Country Report on Holocaust Remembrance and Education in Member Countries.” http://www.holocausttaskforce.org/teachers/educational_reports/country/israel.pdf (accessed September 16, 2007). 
With the Holocaust being one of the few things Israeli Jews agree upon, the comments of Iranian President Mahmoud Ahmadinejad questioning the Holocaust and convening a conference on the subject provoked outrage in Israel. ${ }^{321}$ Not surprisingly, it invited comparison with Haman. "Not far enough away from Jerusalem, the modern-day king of Persia, Iranian President Mahmoud Ahmadinejad, threatens to wipe Israel off the face of the earth, and he's building the nuclear capacity to make that happen,” lamented one columnist on the $9^{\text {th }}$ of Av, commemorating the destruction of the First and Second Temples. $^{322}$ “Today, we are faced with two new dangers: 1 ) the nuclear threat from Iran and 2) the Jew-hating government of Hamas being formed in the West Bank and Gaza,” opines an op-ed column for the Purim holiday reproduced on the Israel National News news site. "The goal of these two groups is to purge the Jews from their land, the land that G-d in His infinite kindness desires to have rebuilt and resettled by the children of Abraham, Isaac and Jacob.” 323

\section{Iran: The "Karbala Paradigm"}

The major motifs and metaphors of Iranian commemorative narrative have deep roots and elements dating back to the axial age: the ongoing cosmic battle between the forces of justice and those of oppression, and fear of foreign intervention in Iranian affairs. Iranian commemorative narrative focuses upon the overarching theme of

321. “Ahmadinejad at Holocaust Conference: 'Israel will soon be wiped out.” Haaretz, Dec. 13, 2006.

322. Uriel Heilman, "Holiday Reflections: On Tisha B'Av, laments for an Israel seemingly on edge of ruin,” Jewish Telegraphic Agency Forum, July 27, 2007.

323. Avi Lazerson, "Purim, Then and Now.” Arutz 7 Website, March 13, 2006. http://www.israelnationalnews.com/Articles/Article.aspx/6086 (accessed Sept. 12, 2007). 
confrontation with invasion and injustice that draws upon pre-Islamic mythic imagery as well as Shi'ite and Sufi themes. Situated on the crossroads of Central Asia, Iranians have had to adapt to the presence of foreign invaders and conquerors throughout their history, whether by means of submission, resistance, or an adaptive fusion of the two known as zerengi. ${ }^{324}$

Iran’s "master commemorative narrative” draws upon Iranian religious tradition, including themes and motifs from Zoroastrian tradition and Sufism as well as Shia Islam, and expresses Iranian vulnerability to foreign invasion, encroachment and interference in Iranian affairs. From the Shahnameh — the ancient epic that recounts the exploits of ancient Iranian heroes - to contemporary exhortations delivered by Iranian political and religious leaders extolling resistance to evil and injustice, and, if required, martyrdom, the underlying theme of Iran's “master commemorative narrative” is the ever-present danger of foreign domination, and the resistance of the Iranian people to the satanic powers seeking to exploit and subjugate Iran by co-opting and corrupting its leaders.

The tenets of Zoroastrianism, which date at least as far back as the 6th-8th century BCE, posit that a benevolent creator deity and an evil spirit were locked in a dualistic struggle in which the forces of good would ultimately triumph. Led by the

324. Anthropologist William O. Beeman defines zerengi (often translated into "cleverness" or "wiliness") as a principle of communication in Iran, according to which "the relationship between the message form (what is said) and message content (what the message is about) cannot be interpreted by a single set of criteria," setting up a tension "between the person initiating communicative behavior and the person interpreting it." One institutional reflection of zerengi is taqiyyeh ("dissimulation"), a precept of Shi 'ism which, according to Fazur Rahman, authorizes, even obligates, the faithful to conceal their true doctrinal beliefs during situations of danger or in a hostile environment. See Beeman, Language, Status and Power in Iran (Bloomington: Indiana University Press, 1986), 27-28. 
Saoshyant, the third of three world saviors who would lead the followers of truth and justice to an ultimate victory against the forces of lies and darkness, the victory of good over evil would culminate in a day of judgment, the resurrection of the dead, and the end of history. ${ }^{325}$ Zoroastrian beliefs about the active involvement of angelic and demonic spirits in human affairs and reward and punishment of individual souls in the afterlife date back to this period, and survive through their incorporation into the tenets and traditions of Judaism and Christianity, ${ }^{326}$ as well as those of Islam. ${ }^{327}$ Both the dualism of good versus evil and the intervention of demonic forces in human affairs are very much in evidence in Iranian political discourse.

The cosmic struggle between good and evil is also reflected in Manichaeism, a dualistic philosophy founded by the third century Persian prophet Mani. Manichaeism,

325. Dorraj, 9-10.

326. R.C. Zaehner, The Dawn and Twilight of Zoroastrianism (London: Weidenfeld and Nicolson, 1961), has been among the strongest proponents of the major influence of Zoroastrianism on Judaism, particularly as reflected in the biblical books of the Prophets and the Dead Sea Scrolls: “That Judaism was deeply influenced by Zoroastrianism during and after the Babylonian captivity can scarcely be questioned, and the extraordinary likeness between the Dead Sea text and the Gathic conception of the nature and origin of evil, as we understand it, would seem to point to direct borrowing on the Jewish side” (51-52). Zaehner asserts that, through Judaism, Zoroastrianism influenced Christianity: "One is tempted to say that all that was vital in Zarathushtra's message passed into Christianity through the Jewish exiles” (171). Many scholars of Judaism consider Zaehner's contention untenable.

327. In a detailed and useful discussion of Zoroastrian-Muslim interaction ("The Encounter of Zoroastrianism with Islam,” Philosophy East and West 42:2, (April 2002), 159172), Marietta Stepaniants concludes that, while Zoroastrianism as a religious institution was eliminated, it was never eradicated as a cultural entity, and its ideas were incorporated into the new Islamic culture, most apparent in Sufism and the val-Ishraq ("illuminationist") schools of Islamic thought. Furthermore many of its customs and practices became an organic part of Iranian Islam (166-167). Stepaniants points out that Boyce's dating of Zarathushtra, as opposed to Zaehner's, makes it "easier to support the contention that religious influence spread from Iran to the eastern Mediterranean world, and not the reverse" (160). 
which incorporated elements of Buddhism and Christianity into Zoroastrianism, identified the "satanic" material world with evil and darkness, and the world of the spirit with good, divinity, and light. "At the end of the struggle, the world would vanish and God would emerge victorious.” ${ }^{328}$ Some scholars see Manichaeism as reflecting the growth of a rigid class system in an era of economic decline. Regarded as dangerously heretical both before and after the rise of Islam, its leaders were persecuted by Iranian rulers. $^{329}$ Zoroastrianism and Manichaeanism have left their mark in Iranian political discourse: "In the dual world of Zarathustra and Mani, one is either on actively involved on the side of the forces of goodness to bring about the realization of divine justice or devoted to an adamant defiance of the material world and to an ascetic life for spiritual enrichment.”330

In the fifth century, a radical offshoot of Manichaeism, which incorporated Zoroastrian dualistic concepts, was founded by Mazdak, son of Bamdad, who Dorraj calls "the founding father of the Iranian intellectual tradition of communalism and

328. Dorraj, 31. Shaul Shaked explains that Manichaen Gnosticism differs from Zoroastrianism and from the dualistic texts found among the Dead Sea scrolls and Jewish apocryphal writing, as well as those of the early Christian church. In the traditional Zoroastrian world view, as expressed in the Pahlavi books, "Getig alludes to the material, visible, and tangible aspect of the world: menog refers to the aspect of the world that is essentially mental, invisible and intangible.” These two aspects of the world are parallel and complementary, and exist simultaneously. The material world, created by Ohrmaz, is essentially good, but evil forces disruptively graft themselves parasitically onto good creations, "Getig and Menog: The Material and Spiritual Worlds.” Circle of Ancient Iranian Studies, SOAS, http://cais-soas.com/CAIS/Mythology/geitig_menog.htm (accessed February 8, 2006).

329. Nikki Keddie, Modern Iran: Roots and Results of Revolution (New Haven: Yale University Press, 2003), 3.

330. Dorraj, 33. 
populism. ${ }^{331}$ Mazdak’s was a political and religious rebellion against poverty, warfare economic decline, and social stratification, that Keddie suggests may have paved the way for the Muslim conquest of Persia in the sixth century. ${ }^{332}$ According to one hadith, followers of Mazdak fled to Arabia and joined the Prophet Muhammad, encouraging him to overthrow the Sassanian dynasty in Iran as well as to incorporate Mazdak’s ideas into Islam. Dorraj argues that the concern for justice in Zoroastrianism, Manichaenism and Mazdakism prepared and predisposed Iranians toward the adoption of Islam. ${ }^{333}$ From its inception, Shi'ism, which became Iran's state religion in the $16^{\text {th }}$ century), has claimed to speak in the voice of, and on behalf of, the poor and the dispossessed.

The Shahnameh (Book of Kings) is a multilayered pre-Islamic epic synthesizing ancient mythological, religious, and national themes with epic traditions dating back to the era of Zoroaster. The very earliest legends have parallels in Indian myth and legend, and may derive from the period prior to the division of Indo-European peoples into Indian and Iranians. ${ }^{334}$ The best known rendition of the Shahnameh, by the tenth century eastern Iranian poet Abolqasem Ferdowsi (940-1020), begins with the creation of the world, and covers the reign of fifty monarchs—-forty seven kings and three queens, some receiving only a few lines of attention, others several thousand-who fight against supernatural forces of evil and teach humanity the arts of civilization. Ferdowsi divides

331. Dorraj, 67.

332. Keddie, Modern Iran, 3.

333. Dorraj, 33.

334. Dick Davis, Introduction to Shahnameh: The Persian Book of Kings, Abolqasem Ferdowsi, transl. Dick Davis (New York: Penguin Books, 2006), xxi. 
pre-Islamic Iranian history into four dynasties: the Pishdadan, Kiyanian, Ashkanian, and Sassanian during three eras—mythical, heroic and historical—spanning the course of six thousand years. Dick Davis notes that although Ferdowsi was doubtlessly a sincere Muslim, who may have “combined 'nationalist' sentiments with Shia sympathies,” his Shahnameh ignores Islamic historiography and cosmology, placing Persian creation myths at center stage and following Persian legendary chronology. ${ }^{335}$

The mythic period and the mythological Pishdadi dynasty began with Kayumars, the primal human and first Persian king, who tamed the animals of the field and taught humans about how to prepare food and clothing. ${ }^{336}$ His beloved son Siamak aroused the jealousy of the evil spirit Ahriman, who engineered his death at the hands of the black demon. ${ }^{337}$ Kayumars and Siamak's son Hushang, with the help of the animals, waged war against the demons and defeated them. Hushang slew the black demon who had killed his father, and succeeded his grandfather as ruler of the world. Just and prudent, Hushang discovered how to make fire from flint and how to separate iron from ore, which led to smithery and the crafting of metal tools. He devised river irrigation, making agriculture possible, and established the festival of Sadeh to celebrate God's gift of fire. $^{338}$

335. Davis, xx. in Ferdowsi.

336. Ferdowsi, 1.

337. Ferdowsi, 2.

338. Ferdowsi, 3-4. 
Sadeh provides a quintessential example of "an act of commemoration that reproduces a commemorative narrative, a story about a particular past that accounts for this ritualized remembrance and provides a moral message for the group members." ${ }^{339}$ A mid-winter festival celebrated in Iran and by many Iranians worldwide on the $10^{\text {th }}$ of the month of Bahman, it is widely described as marking the triumph of the forces of light over darkness. The word Sadeh, meaning one hundred, marks the $100^{\text {th }}$ day since the beginning of winter, one hundred days until the beginning of summer, and fifty days before Noruz, the New Year. ${ }^{340}$ Sadeh illustrates the process of narrativization which selectively draws upon a wide variety of sources and synthesizes them in a diachronic progression to construct the rationale for its commemoration. ${ }^{341}$

The present day "myth of origins" of the festival's observance regards Sadeh not only as the commemoration of the mythic tale of the discovery of fire by primal man, but the lighting of fires by Zoroastrian priests to assist in the sun's revival in the spring and summer. Bonfires were set near temples on the festival, and after they had burned all night, women would take some of the sacred fire to their homes for blessing. A remnant of the sacred fire was maintained inside the temple from year to year. Fires were also lit near water, to keep away demons that could cause water to turn to frost and ice. Its moral

339. Zerubavel, 6.

340. "Sadeh Festival, Celebrating the Birth of Fire,” CHN (Cultural History News Agency), February 2, 2006. Payvand,News, http://www.payvand.com/news/06/feb/1019.html (accessed Feb. 7, 2006).

341. Zerubavel, 6. 
message to the group, from a Zoroastrian perspective, is recollected as being, "the light inside us is a sign of the existence of Ahura Mazda.” 342

Iranian ambivalence toward, and adaptation to, the Arab conquest that brought Islam to Iran is also refracted through the commemorative narrative of Sadeh's observance. Special Sadeh ceremonies are held near Yazd at a cave in a mountain where, according to legend, the last Zoroastrian princess took shelter during the Muslim invasion in 640 CE. Mardavij Zeyari, a ruler of Isfahan in the tenth century, is credited with keeping pre-Islamic Persian traditions alive, setting up bonfires on both sides of the Zayandeh River, and providing lavish feasts, music and fireworks to celebrate Sadeh. ${ }^{343}$ By the twentieth century, the observance of Sadeh was largely confined to Zoroastrians until the festival was popularized by the Shah of Iran, and its observance became widespread, with no religious association. Although there were efforts to repress the preIslamic festivals after the Islamic Revolution, these ultimately proved unsuccessful.

Hushang's son, Tahmures, taught his people how to domesticate animals and how to shear their wool and spin it into fibers from which to make clothes and carpets, as well as how to utilize their milk. With the guidance of his just and righteous vizier, Shahrasb,

342 "Sadeh Festival..." Also noted in this article is that in the Avesta, the sacred text of Zoroastrians, "paradise means an eternal light." CHN, n. 347. The Jewish custom of having a ner tamid (eternal light) in Jewish synagogues may derive from this Zoroastrian tradition., and the mid-winter festival of Chanukah, which began to be observed in Hasmonean times, may have had an antecedent in Sadeh.

343. "Sadeh Festival..." Not pointed out in this article is that, until a few decades ago, the festival was celebrated in Yazd followed the Fasli (seasonal) calendar 100 days before Noruz (around December 11), and in a few villages, it was called Hiromba. Discrepancies in the dates of observance may be traceable from various reforms of the Zoroastrian calendar. See Massoume Price, "Driving out the demons of winter." Circle of Ancient Iranian Studies, SOAS website. http://www.cais-soas.com/CAIS/Celebrations/sadeh.htm (accessed March 31, 2007). 
Tahmures was able to avoid evil, subduing demons by spells and with his mace. In exchange for sparing their lives, these demons taught him the sciences, and the art of writing in nearly thirty foreign languages, including Persian, Arabic, and Chinese. Demons became the administrators of Tahmures' empire, bringing prosperity but also some unintended consequences that would become evident during the reign of Tahmures’ son, Jamshid. ${ }^{344}$

Jamshid was a wise and innovative ruler for five hundred years, during which he radiated the royal farr (divine grace and insight bestowed upon a king). ${ }^{345}$ He designated four occupational castes (priests, warriors, farmers, and tradesmen), ${ }^{346}$ designed weaponry for his soldiers, created enormous wealth for his kingdom by extracting gold, silver, and precious stones from the earth, and undertook massive construction projects. Jamshid inaugurated the New Year festival, Noruz, (new day), still

344. Ferdowsi, 4-5.

345. Davis, xxxvi. Farr seems analogous to the divine spirit that rested on the Israelite kings when they enjoyed God's favor.

346. These closely parallel the early class divisions of Indian society found in the $\underline{R g}$ Veda: the brahmana (priests); ksatriya (warriors), vaisya (peasants) and sudra (serfs). A.L. Basham, in The Wonder that was India (New Delhi: Rupa \& Co, 1995) suggests that these class divisions (varnas - literally, “colors”) divisions predate Aryan settlement in India. 35-36. There is one obvious difference: as noted above, in the Shahnameh tradition, craftsmen constituted the fourth class, rather than serfs. Basham suggests that "Coinage may have been introduced into India towards the end of the sixth century BC, through Persian influence..." (44) Metal craftsmanship was therefore most likely more advanced in Iran than India, and progress in the use of metals is evident in the innovations attributed to all of the Pishdadi kings. That occupational class divisions never became either as rigid or as enduring in Iran as they did in India points to the possibility of greater social mobility in Iranian society, made possible, and perhaps even required, by Iranian absorption of migrating and conquered peoples, as well as the cultural, intellectual, technical and economic exchanges that took place along the Silk Road. 
celebrated at the vernal equinox as a major national festival in Iran, and throughout the Persianate world. During the reign of Jamshid, death was unknown in the world, and with the demons as their slaves, people knew no sorrow or evil. ${ }^{347}$

However, when he became overly proud, Jamshid's farr dimmed, and his wisdom abandoned him. As a result, dissension and disobedience broke out in Persia. After he had killed his father, the good and generous Arabian king Merdas, Zahhak was granted the kingship of Persia by a contingent of Jamshid's fractious soldiers. Cruel and tyrannical, the serpentine Zahhak ruled the world for a thousand years from his palace in Jerusalem $^{348}$ until a blacksmith by the name of Kaveh led a revolt against him. Kaveh’s apron (derafsh kaviani) became the banner of the insurrectionists. ${ }^{349}$

Shahnameh imagery still pervades Iranian political culture. Ayatollah Khomeini himself stated, "The religious leaders will hoist the banner of Islam to exact vengeance on this Zuhhak of the age...” 350 In the Iranian election in June 2005, it was widely publicized that Mahmoud Ahmadinejad, the unexpected victor, was the son of a

\section{Ferdowsi, 7.}

348. Jerusalem was under Arab rule 636-1099, including the late tenth-early eleventh century, when Ferdowsi composed the Shahnameh.

349. Ferdowsi, 8-21.The Sassanian dynasty (224-661) called its imperial banner the Derafs-e Kavian. A. Sh. Shahbahzi, "History of Iran: the Sassanian Army. Iran Chamber website. <http://www.iranchamber.com/history/sassanids/sassanian_army.php>. More recently, according to testimony reportedly presented to a French court, the US government funded a Parisbased organization known as Derafsh Kavian, created by Manoucheer Ganji and Reza Mazlooman (also known as Koorosh Amianamesh) opposed to Iran's Islamic regime. "Court Told Iranian Agents Killed Dr. Reza Mazlooman.” Iran Press Service, June 20, 2001.

350. Khomeini, Message to the People of Azerbaijan, February 27, 1978, in Islam and Revolution, ed. Algar, 230. 
blacksmith. The western media inferred from this that it was Ahmadinejad's humble origins that won him the votes of Iran's lowest social and economic classes. Iranian commentators, however, also pointed out that Ahmadinejad represented more that a man from a Iran's lowest socio-economic stratum who was able, through military service in the Basij and Revolutionary Guards, to become Teheran's mayor and Iran’s president: "He symbolized the legendary Kaveh, the son of a blacksmith in Iranian history who had led a successful revolt against the tyranny of Zahhak.”351

In the Shahnameh, Kaveh sought out and located Feraydun, a descendant of the Pishdadi royal line. Feraydun joined Kaveh's revolt, and after a cosmic battle between good and evil that defeated Zahhak, became king. After ruling for 500 years, Feraydun divided his kingdom among his three sons. He gave his eldest son, Silim, the region of Rum. ${ }^{352}$ Tur received Turan (Central Asia, Turkistan, and China). Feraydun gave Iran, the largest and choicest part of his kingdom, to Iraj, his youngest and most beloved son. ${ }^{353}$ Jealous, his step-brothers murdered the unarmed Iraj as he attempted to reconcile

351. Majid Tehranian, “Opinion: What Happened in the Iranian Presidential Election.” Iranian.com, June 30, 2005.

http://www.iranian.com/MajidTehranian/2005/June/Elections/index.html (accessed July 20, 2005).

352. Davis explains that th region known as Rum (adjectival form: Rumi) is difficult to translate consistently in the Shahnameh. "Rum" denotes the civilizations west of Iran-Asia Minor and Europe. Sekander is a Rumi, as are the Romans and the Byzantines, xxxvi. Similarly, the term Kittim is used in the Hebrew Bible (e.g. Genesis 10:4; Numbers 24:24; Daniel 11:29-30 ), several fragments of the Dead Sea Scrolls (War Scroll and pesharim), and the book of I Maccabees 1:1; 8:5 to collectively refer to Greeks and Romans who came from the West. In Josephus's Antiquities (I:128), he says the Hebrews apply the term Kittim to all the islands and to most of the countries near the sea.

353. This attests to the antiquity of "Iran" as the ancient, popular, and probably the original name, for Persia (from the Greek Persis). Reza Shah formally readopted the name in 1935. 
with them, even offering them his crown and throne. ${ }^{354}$ Eventually, Feraydun groomed Iraj's grandson Manuchehr to be his successor. After Manuchehr had avenged the death of his grandfather by fighting several battles with Silim and Tur, killing them, his greatgrandfather presented Manuchehr with his kingdom and the royal farr. ${ }^{355}$ Yet the division of Feraydun's kingdom between Iran, Turan, and Rum remained in place, and the wars between Iran and Turan continued for generations.

The period from Manuchehr to Sikander (the latter known in Western historiography as “Alexander the Great”) represents Iran’s heroic age, to which about two thirds of Ferdowsi's 60,000 couplets are devoted. The king of Turan, Tur's bellicose grandson Afrasyab, killed Nozar, Manuchehr's son and successor. Taking advantage of the power vacuum after Nozar's death, Afrasyab ruled Iran himself for twelve years. Iranian champions, rejecting the entitlement to kingship of Nozar's, sons, placed eightyyear old Zav, Feraydun's descendant, on Iran's throne. During his brief six years as king, during which he ruled wisely and justly, Zav fought Afrasyab. Zav and Afrasyab then signed the first of what would be many treaties confirming the Oxus River as the territorial boundary between Iran and Turan, which Turan's rulers would affirm—and violate-throughout the course of the epic. ${ }^{356}$

354. Ferdowsi, 28-46.

355. Ferdowsi, 47-62.

356. Ferdowsi, 110-129. 
Even the most superficial reading of the Shahnameh reveals that, while its title and major protagonists are Iran's kings, the true heroes of the epic, to whom Ferdowsi devotes the most attention, are the wise viziers and the intrepid "champions" whose shrewd intelligence and bravery enabled Iranian kings to gain and retain power. Ferdowsi says of Shahrasb, the vizier of Tahmures, "(H)e was the king’s star of good fortune, and the souls of the malevolent were under his control.” Wishing Tahmures' reign to be a just one, "he guided him in righteous paths, so that Tahmures lived purified of all evil, and the divine farr emanated from him.”357 The exploits and achievements of Sam, the champion during the reign of Manouchehr, his son Zal, who, during his thousand years as champion, not only serves but shapes the Kayanian royal line, and Zal's son Rostam, whose physical prowess is matched by his mastery of "psychological warfare” during his 600 years as champion, drive much of the dramatic momentum of the Shahnameh.

The character of Seyavash provides a link not only between Iran's pre-Islamic and Shi'ite traditions, but also contains some motifs from the biblical and Quranic story of Joseph, a popular personality among Persian poets. Seyavash was the son of the king Kai Kavus and a beautiful Turkish princess, a descendant of Feraydun, rescued by Kavus' knights. Brought to Kavus and made one the concubines of his harem, she gave birth to a beautiful son, a "lion cub" who was entrusted for princely training to Rostam. Years later, the young prince returned to his father's court. ${ }^{358}$

357. Ferdowsi, 5.

358. Ferdowsi, 215-217. 
The queen, Sudabeh, developed a passion for Seyavash. The daughter of the king of Hameveran, who hated the Persian people, Sudabeh secured Kavus’ permission to marry Seyavash to one of her daughters, but tried to seduce him herself. Seyavash resisted Sudabeh’s lustful advances, despite her persistence. When Sudabeh accused Seyavash of rape when he refused to yield to her, Kavus, was skeptical. While Kavus recognized Seyavash's innocence, he nonetheless loved Sudabeh, and this allowed her to persist with her scheming again Seyavash. ${ }^{359}$

In the meantime, Kavus learned that Afrayasab was preparing an attack on Iran with a hundred thousand cavalry massing at the border. Seyavash persuaded Kavus to allow him to lead the army in its battle against Turan, proving his loyalty to his father and getting him away from Sudabeh. Kavus then asked Rostam to accompany Seyavash. Seyavash was successful in a series of battles. Afrasyab, after a dream that, a dream interpreter explained, predicted the dire consequence of war between Turan and Iran, decided to sue for peace with Seyavash, who sent Rostam with a letter to Kavus for permission to reconcile with Afrasyab. Kavus refused, treating Rostam with anger and contempt, sending him back to Seyavash demanding that he break his oath of truce to Afrasyab. ${ }^{360}$

Heartsick at his father's rejection, because he would not violate his pledge, Seyavash took shelter with Afrasyab in Turkistan, marrying his beautiful daughter

359. Ferdowsi, 217-228.

360. Ferdowsi, 228-242. 
Farigis. ${ }^{361}$ But the scheming of Afrasyab’s brother Garsivaz (Seyavash's own greatgrandfather) persuaded Afrasyab that Seyavash had betrayed him. Seyavash was brutally attacked on Afrasyab's orders, and his head was cut off. ${ }^{362}$ The gruesome and graphic details of the murder of Seyavash and the mourning for him are similar to those recounted of the martyrdom of Husayn at Karbala (see below). The son of Farigis and Seyavash, Kay Khosrow, survived, and became the successor to Kay Kavus. But Kay Khosrow became weary of kingship. Immersing himself in prayer, he was visited by the angel Sorush in a dream, and offered the opportunity to choose occultation. After explaining his decision to Zal, and conferring the kingship on Lohrasp, Kay Khosrow disappeared. $^{363}$ (His occultation can also be connected to the Islamic theme of the occultation of the Twelfth Imam.)

Ferdowsi devotes far less of the Shahnameh to the more historical dynasties of the Ashkanians and Sassanians, and, as Davis notes, the narrative lacks some of the epic force of the heroic era. Compensating for that is Ferdowsi's underlying sense of foreboding that Persian civilization is soon to come to an end with the Arab conquest. ${ }^{364}$ In their final battle, Ferdowsi contrasts the resplendent commanders of the Iranian army with their fierce, hardy, and ascetic Arab opponents. The epic ends (except for Ferdowsi's account of how he wrote it) with a stark and muted assertion of fact: "After

361. Ferdowsi, 253-256.

362. Ferdowsi, 266-274.

363. Ferdowsi, 346-357.

364. Davis, in Ferdowsi, xxxii. 
this came the era of Omar, and when he brought the new faith, the pulpit replaced the throne."365

The Shahnameh is an enormous compendium of Iranian legend, containing hundreds of characters involved in myriad incidents and encounters with each other, only a few of whom have any recognizable historic referents. What the Shahnameh provides is not history per se, but a broad mythographic narrative framework, replete with commemorative associations and possibilities. It also provides a diachronic glimpse, from a cultural and literary perspective, of the Iranian view of power and authority in their own country, as well as Iran's relations with other states.

Caroline Ziemke’s rather faulty reading of the Shahnameh leads her to infer that its lesson is that "Persian culture thrives when its leaders use their power to keep it isolated and suffers when they pursue power-sharing with the outside world." While xenophobic sentiments are evident in the Shahnameh as well as in the Iranian "master commemorative narrative,” it is almost always the corruption of Iran’s own leaders by pride, greed, and arrogance that makes them amenable to pursuing unholy alliances with demonically-inspired forces outside Iran. ${ }^{366}$ Wars, while sometimes waged for noble

365. Ferdowsi, 852.

366. Ziemke badly mangles the Shahnameh narrative (and provides some clues that she may not have read it) when she depicts the Shahnameh as "the mythic saga of the reign of Jamshid, who liberated Persia from the rule of Zahhak, a Faust-like Arab prince who became king of Persia through a pact with the Lord of Darkness. Zahhak's three hundred-year reign is a period of suffering and evil that ends when Fariydun, a Moses-like figure, defeats the forces of evil to usher in five hundred years of peace and prosperity. Persia eventually collapses into civil war when Fariydun's sons make alliances with central Asian warlords, allowing Persia, once again, to fall to the mercy of foreign interlopers until Jamshid ends the civil war and reunifies Persia." Carolyn Ziemke, "The National Myth and Strategic Personality of Iran: A Counterproliferation Perspective.” in . Utgoff,, ed. The Coming Crisis: Nuclear Proliferation, U.S. Interests, and 
reasons such as honor and justice, are sometimes the result of misunderstandings or worse, the deliberate and provocative machinations of devious and power-hungry characters acting manipulatively out of malice and/or greed.

These are themes that resonate in Iran's master commemorative narrative irrespective of regime. Davis notes that the poem was popular with the Pahlavi shahs because it exalted Iran’s pre-Islamic civilization, and implies some question as to whether the exalted status of the Shahnameh continued under Iran's Islamic regime. Heggay Ram's study of Iranian school textbooks demonstrates that, despite many of the revolutionary regime's differences in educational goals from those of the Shahs, "the Islamic Republic’s evident endeavor to integrate the Islamic tradition more forcefully into Iran's political culture comes hand in hand with an equally forceful articulation and inculcation of the ancient regime's national tradition.” The Islamic Republic has appropriated the Pahlavi narrative, "which presupposed a linear movement of the

World Order (Cambridge and London: MIT, 2000), 91. According to the Shahnameh, Zahhak's father, also an Arab, is a wise and good king. It is only after Jamshid has ruled for 500 years and becomes proud and arrogant against God that Zahhak is able to gain control of his kingdom. Other errors in Ziemke's brief summary of the Shahnameh include: 1) Zahhak rules for a thousand years, not three hundred; 2) Fariydun's son Tur and his descendants are the "central Asia warlords" who wage war against Iran. 3) Jamshid, having lived over a millennium and a half earlier, could not possibly be construed as having ended the fratricidal war between Iran and Turan. 4) After Fariydun, the lifespans and reigns of the kings were greatly reduced to about 100 years. However, the mythic national champions continue to live lives of spanning several centuries. Finally, most of the Shahnameh, as noted above, is devoted to the heroic period, while Jamshid ruled in the earlier mythic period. Jamishid's reign cannot be regarded as the primary theme of the Shahnameh. While it is commendable that analysts like Ziemke are looking at cultural factors in order to understanding Iranian thinking, it is unfortunate that her reading of the Shahnameh is so flawed that it would be difficult to discern the cultural messages Iranians garner from it. 
'Iranians’ as a unified group from pre-Islamic to Islamic times.”367 Furthermore, Ram’s study reveals that Islamic consciousness is not a replacement for or alternative to Iran's national myth, but adds Islamic terminology to that myth. "Consequently, political Islam remains within the confines of Iranian nationalism.”368

Another religious and cultural source of foreign policy imagery is the traditions associated with Ali ibn Abi Talib, and his son, Husayn. Ali, who became the Prophet's son-in-law when he married Mohammad's daughter, Fatima Zahra, was the last of "the four "rightly guided caliphs" and of the first imams revered by Shi`ites. ${ }^{369}$ The heroic figure of Ali plays a special role in Shi'i ritual and tradition. A collection of ethical aphorisms, letters, and sermons, the Naj al-balagha (Path of Eloquence), is believed to be an authentic work, second only in importance to the Qu'ran. His words and actions are invoked in legal procedure, and he epitomizes Islamic piety and commitment to social justice. ${ }^{370}$

Ali Shariati argued that there was a disjuncture, not between Sunnism and Shi`ism, but within Shi'ism itself, with authentic Shi`ism being the Shi`ism of Ali. On one side was the current existing Shi ‘ism that had become Iran’s state religion under the Safavids. Shariati posited that "Safavid Shi`ism" was, in reality, Umayyad Sunnism

367. Haggay Ram, "The Immemorial Iranian Nation? School Textbooks and Iranian Historical Memory in Revolutionary Iran.” Nations and Nationalism 6, no. 1 (2000), 85.

368. Ram, 86.

369. For a full discussion of the question of succession to Mohammad, including the foundations of the Sunni-Shi'ite divide, see Husain M. Jafri, Origins and Early Development of Shi'a Islam (London and New York: Longman, 1979.

370. Gieling, Revolutionary Iran, 112. 
(tasanon-e Ummavi), an institutionalized counter-revolutionary movement that operated through the clergy to defend the status quo and support the ruling class, "reconciling religion with 'authoritarian and corrupt monarchies.” In contrast, “Ali’s Shi ‘ism” was the original, revolutionary Shi'ism that was identical with "Mohammad’s Sunnism" (tasanon-e Mohammadi). ${ }^{371}$ Ali was the last of "the four rightly guided caliphs" and of the first imams revered by Shi'ites. ${ }^{372}$

Ali's instructions and advice served as models during the Iraq war. The Battle of Sifflin was used both to mobilize for and to justify the war. Paradoxically, Gieling points out that Ayatollahs Kashani and Ardabil exhorted Iranians "to drench their swords in Saddam’s blood.” When Iran repelled the Iraq onslaught and went on the offensive, Ardabil quoted Ali as saying that "people who fight on their own ground will not find salvation, and courageous Muslims must not allow their enemy to fight on their territory." That the Battle of Sifflin in which Ali engaged ended in arbitration was not mentioned by Iranian leaders. ${ }^{373}$

371. Ali Rahnema, An Islamic Utopian: A Political Biography of Ali Shari’ati (London and New York: I.B. Tauris, 1998), 301.

372. Husain M. Jafri, Origins and Early Development of Shi'a Islam (London and New York: Longman, 1979) provides a thorough overview of the controversies between Sunnis and Shi`a.

373. Gieling, 113. 
What Michael Fischer describes as the "Karbala Paradigm" ${ }^{374}$ is constructed around Imam Husayn, the son of Ali and Mohammad's daughter Fatima. According to the traditional Shi‘i account, Husayn’s elder brother, Hasan, the second imam, relinquished his claim to the caliphate, acknowledging Mu'awiya, the first Umayyad, as caliph. After Hasan's death, his younger brother, Husayn, became the third imam, and also did not challenge Mu'awiya. When Mu'awiya died in 680, the caliphate passed to his son Yazid, to whom Husayn refused to swear loyalty. ${ }^{375}$ According to the broad outlines of the most commonly accepted accounts in Shia tradition, ${ }^{376}$ letters were dispatched to Husayn in the Hejaz from southern Iraq, asking him to lead a rebellion against the "politically oppressive and morally corrupt” Yazid, headquarted in Damascus.

Husayn, after sending out scouts to the region, decided to journey to Kufa with only his family and a few dozen supporters, although he had been warned that the Kufans could not be trusted, since they had proven themselves unreliable to both the Prophet Mohammad and to Ali. When they arrived in the Karbala desert, Husayn and his party were surrounded by the troops of the Governor of Kufa, Ubayd Allah ibn Ziyad, who cut them off from any access to water and would not let them enter the city. Attempts to

374. Michael Fischer, Iran: From Religious Dispute to Revolution. Cambridge: Harvard University Press, 1980.

375. Gieling, 113-114.

376. Kamran Scot Aghaie notes, "Like many other famous historical events, the tale of the Battle of Karbala has been told and retold over the centuries without a single authoritative version emerging to supplant completely all others.” For purposes of this study, as for Aghaei's, "it is only necessary to keep in mind what Shi 'is have historically considered to be the "correct" representations of this event.” Kamran Scott Aghaie, The Martyrs of Karbala: Shi 'i Symbols and Rituals in Modern Iran (Seattle: University of Washington Press, 2004), 8. 
negotiate a retreat back to Mecca failed, Husayn continued to refuse to swear an oath of allegiance to Yazid, and assistance from Kufans, never materialized. Husayn's half brother, Hazrat-e Abbas (popularly known in Iranian tradition as Abolfazl), was killed while trying to get water for the women and children. On the $10^{\text {th }}$ (ashura) day of the month Muharram, Husayn and all the men with him were slain and decapitated. The women and children were sent with the severed heads to Yazid in Damascus. ${ }^{377}$

The "Karbala Paradigm” became a metaphor for the relations between Shi'is and Sunnis, and the basis for numerous Shi' $i$ beliefs and practices, as well as a turning point event in the Shi'i narrative of the unfolding of human history. Mourning for the family members of the Prophet Mohammad provides a means for salvation and the opportunity to enter paradise, through the performative reenactments that take place on the tenth of Ashura. Kamran Scot Aghaie points out that "the rituals associated with the battle have historically served as a vehicle for expressing and strengthening a variety of political and social relationships, associations, and identities." Observance of mourning rituals for the Prophet's family, which began almost immediately after the Battle of Karbala, was not limited to Shi'ites—Sunnis participated in them as well. Political use of Karbala served as the prototype for several rebellions within the caliphate, the most successful of which culminated in the Abbasid overthrow of the Umayyads in 649-650. By 963, there were accounts of public mourning rituals that appear to be precursors of what became the

377. Moojan Momen, An Introduction to Shi 'i Islam: The History and Doctrines of Twelver Shi`ism (New Haven: Yale University Press, 1983), 29. 
Muharram processions, promoted by the Buyid rulers of southern Iran, who were Shi 'ites. ${ }^{378}$

Numerous historiographic accounts and elegies about Karbala were composed. The Safavids, who adopted Twelver Shi'ism as the official religion of Iran, gave new meaning and new forms to the Karbala commemorative rituals under state sponsorship, which became more exclusively identified with Shi'ism, since not many Sunnis were left in Iran. ${ }^{379}$ The rowzeh khani began as a Muharram sermon given by a specially trained speaker, designed to elicit cries of mourning for Hussein that were regarded by Shi 'ites as a means of attaining salvation in paradise. The speaker's goal was "to move his audience to tears through his recitation of the tragic details of the Battle of Karbala.” By the late eighteenth century, the rowzeh khani had evolved into an elaborate ritual that became known as the taziyeh khani, an elaborate theatrical performance with a large cast of actors, both professional and amateur, a director, props, elaborate costumes and a staging area. $^{380}$

Ta'ziyehs reached their peak popularity during the late Qajar period in the late nineteenth and early $20^{\text {th }}$ centuries. Banned frequently by the Pahlavi shahs, and lacking wealthy sponsors, the taziyehs continued to be performed in traditional neighborhoods and villages. Since the Islamic Revolution in 1979, the Ministry of culture has tried to preserve the taziyeh tradition, at least as a cultural artifact, by broadcasting taziyehs on

378. Aghaie, 9-10.

379. See Rula Jurdi Abisaab, Converting Persia: Religion and Power in the Safavid Empire (London and New York: I.B. Tauris, 2004).

380. Aghaie, 12-13. 
television and sponsoring performances. However, in the Islamic Republic of Iran, the rowzeh khani and the Muharram processions are the primary public Karbala commemorations, although taziyehs are have a large following in some sectors of Iranian society and are still performed regularly. ${ }^{381}$

The rituals of the rowzeh khani the taziyehs made the story of Karbala familiar to most Iranians. It offered “a ready-made analogy for both identifying and countering injustice,” and provided the faithful with an opportunity to redeem Husayn's death by struggling against injustice. ${ }^{382}$ Inherent in the Karbala Paradigm, and within Shi`ism, is a paradox, in that the message of Husayn's martyrdom lends itself to both "patient endurance of suffering at the hands of those with political power," while at the same time "Husayn is praised and commended for not submitting to tyranny...fighting even in the face of overwhelming odds and certainty of martyrdom.” Mobilization for martyrdom could thus take activist or quietist forms. ${ }^{383}$ This paradox, according to Momen, gives the Karbala Paradigm “extraordinary political versatility.”384 Fouad Ajami compares Karbala to "a tapestry of many threads":

No tale of such great pathos and tragedy could have left men with a single unambiguous message. Stood on one end, Karbala was a tale of choice and principle, the story of a man standing up when he could have groveled and

381. Aghaie, 13.

382. Stephen C. Poulson, Social Moverments in Iran: Culture, Ideology and Mobilizing Framewords. (Lanham, MD: Lexington Books), 2005.

383. Gieling, 115.

384. Momen, 236. 
acquiesced. Stood on the other end, it was a tale of doom and defeat. Karbala celebrated the grandson of the Prophet who fell in battle. But in the dark recesses of the mind, Karbala and the reiteration of its grim happenings could be an invitation to submission to powers that could not be defeated, to odds that could not be overcome. ${ }^{385}$

A decade before the Islamic Revolution in 1970, Ayatollah Morteza Motahhari (1920-1979), who Dabashi considers to be "the Chief Ideologue of the Islamic Revolution," ${ }^{386}$ delivered one of his lectures on the $40^{\text {th }}$ day after the commemoration of the martyrdom of Imam Husayn. "Karbala is not only in one day, it always is," he declared. Dabashi points out that what distinguished Motahhari's use of the phrase was the context in which it was delivered. Motahhari believed that the dual pincers of the Shah's tyrannical monarchy and the revolutionary claims of secular youth had to be countered with an Islam that not only had been updated with the revolutionary and rationalistic spirit of the age, it also had to be rid of the misery and passivity into which it had fallen.

In principle, Motahhari opposed any mode of identification with the Karbala event that did not simultaneously and immediately create a sense of heroism, sacrifice, and activist commitment to take one's destiny into one's own hands...Those who were not killed in Karbala in person are still martyrs if they truly believe in the martyred Imam and follow his example in valor, sacrifice, and struggle for justice. ..This is a remarkable extension of the reconstructed sacred history into the contemporary realities of Mottahari's time. The ideal and idyllic state of having fought alongside Imam al-Husayn is historically progressed and symbolically identified, on a one to one basis, with fighting for just causes today or any other day. Finding a just cause to fight for, in the immediacy of their historical concerns, could very well be left to people’s imagination. ${ }^{387}$

385. Fouad Ajami, "Imam Musa Sadr", in Expectation of the Millennium: Shi'ism in History, in Seyyed Hossein Nasr, Hamid Dabashi and Seyyed Vali Nasr, eds. New York: State University of New York Press, 1989.

386 Dabashi, Theology of Discontent, 147.

387. Dabashi, Theology of Discontent, 176. 
The most critical factor in the outcome of the Islamic Revolution, Momen suggests, was the way Khomeini was able to capture the imagination of the masses by drawing upon numerous Shi`i themes with strong emotional appeal. ${ }^{388}$ On November 23, 1978, Khomeini issued a declaration from his exile in Neuphle-le Chateau in France, a week before Muharram: “The leader of the Muslims taught us that if a tyrant rules despotically over the Muslims in any age, we must rise up against him and denounce him, however unequal our forces may be, and that if we see the very existence of Islam in danger, we must sacrifice ourselves and prepare to shed our blood.”389 Khomeini called upon Iranians to use the Muharram observances to mobilize in opposition against the Palahvi monarchy:

There is no need to remind you that mourning assemblies must be fully independent, and not depend on permission by the police of that subversive body called the security organization. Dear people, organize your gathering without referring to the authorities, and if you are prevented fro holding them, gather in public squares, in thoroughfares and streets, and proclaim the sufferings endured by Islam and the Muslims and the treacherous acts of the Shah's regime. ${ }^{390}$

In early January, 1979, Khomeini began to give instructions for the transfer of authority taking place in Iran, while calling for continued demonstrations. The slogan for the revolution became kullu yaw ashura, kullu maqam Karbala ("Every day is ashura,

388. Momen, 288.

389. Khomeini, "Muharram: The Triumph of Blood Over the Sword,” November 23, 1978, in Islam and Revolution, 242.

390. Khomeini, 244. 
every land is Karbala"). ${ }^{391}$ The fortieth day after Ashura commemorating Imam Husayn had an exceptional meaning, during a year in which the monarchy would come to an end.

It is as if the blood of our martyrs were the continuation of the blood of the martyrs of Karbala, and as if the commemoration of our brothers were the echo of the commemoration of those brave ones who fell at Karbala. Just as their pure blood brought to an end the tyrannical rule of Yazid, the blood of our martyrs has shattered the tyrannical monarchy of the Pahlavis. ${ }^{392}$

Husayn’s self-sacrifice, depicted as a struggle against tyranny, was the model for resistance against the Shah. "The identification of rulers with Yazid had been used before by their clerical opponents as an instrument to rouse people against the Shah, but during the revolution the use of 'Karbala” as a representation of Iranian politics was broadened to include Husayn's sacrifice and martyrdom as an example for the Iranian population.”393

After the Iraqi attack on Iran, Husayn became the symbol of Iranian resistance against Saddam Hussein. Karbala, being in Iraq, became not only a model for, but a literal reenactment of, Husayn's martyrdom. ${ }^{394}$ Immediately after the outbreak of the Iraq war, Iranian leaders compared the task of the Islamic republic to that of Husayn, restoring justice, protecting Islam, and fighting against tyranny. Khomeini declared that no propaganda or conspiracy theory could hide the fact that "You are in the right just like

391. While widely credit to Shariati (Rahnema writes that Shariati "coined” the slogan, (315) the phrase is also credited to Imam Jafar al-Sadiq (702-765). See Poulson, 44.

392. Khomeini, “The Fortieth Day after Ashura,” Declaration issued at Neauphle-le Chateau, January 15, 1979. Islam and Revolution, ed. Algar, 249.

393. Gieling, 107.

394. Gieling, 117. 
the imam, Lord of the Martyrs, was in the right and become superior with so few in number. Although he was martyred together with his sons, he revived Islam and brought disgrace on Yazid and the Ummayad dynasty.” Iranian solders were compared to Husayn's followers who stood with him at Karbala. ${ }^{395}$

Since the Iraq war ended, "Karbala" has been invoked after the war to warn Iranians "to draw the line between friend and foe," not just against "global arrogance, but also against Iranian leaders favoring rapprochement with the West: "It is sad to see certain politicians making overtures to the enemy, even though that enemy is only getting more hostile and more cruel daily...We must remember Karbala and the struggle of Imam al-Husayn...”396 Ashura, like Auschwitz, is a sacralized image with enormous power for mobilizing resistance and defense.

\section{Summary}

The Auschwitz paradigm presents the Jewish people as the perpetual victims of history. Iranian use of imagery related to the martyrdom of Imam Husayn at Karbala depicts the Iranian people in the role of the Shi'ite martyr in its confrontations with its enemies. Both the "people that dwells alone" and the "Karbala paradigm" are master commemorative narratives that might be expected to emerge from beleaguered and isolated political cultures.

395. Gieling, 116-177.

396. Ayatollah Mohammad Yazdi, "Yazdi Leads Friday Prayers: Delivers Arabic Sermon,” Tehran Voice of the Islamic Republic, July 31, 1992. FBIS-NES-92-148, July 31, 1992, Doc. NC3106134192. 
In point of fact, however, neither Israel nor Iran has ever been isolated. Jews and Iranians have been among the most cosmopolitan of peoples, absorbing and serving as mediators in cross-cultural transmission but also in generating their own rich literature and traditions. This cosmopolitanism, ironically, may explain why, in the process creating a new political definition of nationhood and circumscribing it within ethnoreligious parameters, images from are adopted that deliberately convey an image of exceptionalism and isolation.

These images of Auschwitz and Ashura testify not only to the reverence for martyrdom in Jewish and Shia religious tradition, but also testify to their potential for transformation into models for rejection of political passivity. The recasting the messages from the past transmitted through these paradigms into messages of resistance testifies to the power of myth, particularly religious myth to adapt to radical shifts and major alterations in the political environment while maintaining a historiographic tie to tradition through narrative and invented traditions. 


\section{CHAPTER IV}

\section{ISRAEL, IRAN AND THE “WAR ON TERROR”: MASTER COMMEMORATIVE NARRATIVES IN PRACTICE}

\section{Introduction}

Within a day of the terrorist attacks on the World Trade Center and the Pentagon on September 11, 2001, counter-terrorism analysts had identified Osama bin Laden’s Al-

Qaeda network as its most likely perpetrator. ${ }^{397}$ Al-Qaeda was an umbrella organization known to be operating in over sixty countries, affiliated with terrorist groups from Egypt to Pakistan and Kashmir, with fundraising offices in the U.S. and Europe. Bin Laden, who had openly declared a jihad against Americans in early $1998,{ }^{398}$ had issued a threat of a major operation against the U.S. three weeks earlier. ${ }^{399}$ Experts agreed that AlQaeda, considered to have been responsible for the subsequent terrorist attacks against the U.S. embassies in Nairobi and Dar es-Salaam, and linked to numerous terrorist attacks including the explosion of the World Trade Center in New York in 1993, the massacre at Luxor, the bombing of the USS Cole, and to conspiracies to assassinate the

397. John Solomon, “U.S. Inquiry Focuses on bin Laden,” AP, Sept. 12, 2001.

398. “Text of Fatwa Urging Jihad Against Americans.” Al-Quds al’Arabi, Feb. 23, 1998.

399. Among the first to identify Bin Laden as being "almost certainly" behind the attack on the World Trade Center was Abdel-Bari Atwan, editor of the London-based Arabic-language weekly news magazine al-Quds al-Arabi, who had interviewed Bin- Ladin and maintained close contacts with his followers. See "Usamah Bin-Laden: the Saudi magnate who dreams of a 'world-wide holy war,'” To Vima, Sept. 12, 2001, World News Connection Foreign Broadcast Information Service, National Technical Information Service, U.S. Department of Commerce. doc. FBIS-NES-2001-0912, Sept. 12, 2001. Subsequent citations are to WNC and FBIS document number (all documents available by subscription through DIALOG. http://library.dialog.com/.) 
Pope as well as U.S. and Egyptian presidents, was probably the only network with the motivation, capability and means to carry out such a large scale attack. ${ }^{400}$

The immediate reaction in Israel to the September 11 attacks anticipated that the U.S. public, as well as its policymakers, would now be better able empathize with the horror of vulnerability to random terrorist attacks with which Israelis have had to cope for decades. ${ }^{401}$ Within hours, Israeli government leaders and politicians were envisioning and calling for massive U.S. retaliation against "Islamic fundamentalism" in which Israel was uniquely equipped to be a partner, even a mentor, of the U.S., rather than shunted to the sidelines, as it had been during the Gulf War a decade earlier. One of its prime targets, Israeli sources were certain, would be Iran.

Iranian President Mohammed Khatami was among the first Muslim leaders to convey his condemnation of the events of September 11 and to express his sympathy for the American people. Khatami condemned the hijackings and the terrorist attacks, and expressed his deep sorrow and sympathy with the American nation. He called for the international community to stem and eradicate terrorism, noting that Iran "is treading a road to uproot terrorism and to this end, it will spare no efforts." ${ }^{402}$ A influential conservative Iranian spokesman declared that the perpetrators of the attack were most

400. Faye Bowers and Scott Peterson, "Who Could Have Done It? A very short list." Christian Science Monitor, September 12, 2001 edition http://www.csmonitor.com/2001/0912/p1s2-wogi.html (accessed Sept. 14, 2001).

401. Greer Faye Cashman, “Katsav Expresses Nation's Sorrow.” Jerusalem Post, Sept. 12, 2001. http://www.jpost.com/Editions/2001/09/12/News/News.34648.html (accessed Sept. 14, 2001). Also see Leslie Susser, “A Whole New World,” Jerusalem Report, Oct. 22, 2001, 12.

402. “Iran's Khatami Condemns Wave of 'Terrorist Attacks' in US,” Agence France Presse, Sept. 11, 2001. 
likely Israeli agents, since only they would have had access to the resources needed to carry out the attack and because the consequences of the attack favored Zionist interests. ${ }^{403}$

This chapter presents a detailed chronology and content analysis of the statements of political leaders immediately after the events of September 11, 2001, in order to demonstrate the ways in which Israeli and Iranian political leaders confronted each other and competed to achieve their foreign policy goals through the U.S. "war on terror" declared on September 11, 2001. It provides a content analysis of published statements by politicians and other politically influential individuals between the September 11 attacks on the World Trade Center and the Pentagon, and the aftermath of President George W. Bush’s State of the Union address on January 29, 2002.

This research does not attempt to empirically evaluate any "objective” military threat that Iran and Israel pose to one another, whether in terms of ballistic missile range, nuclear weapons development or small arms sales to their respective enemies. Rather, it observes some interesting features of the ways that Israelis and Iranians talk about each other, and the ways in which they use discourse predicated upon their respective commemorative narratives in order to articulate foreign policy goals. These have not, to my knowledge, been closely analyzed elsewhere, particularly not from a comparative perspective.

403. “America and World Following Black Tuesday,” Siyasat-e Ruz, Sept. 13, 2001, WNC Doc. FBIS-NES-001-0925 


\section{The Clash of Narratives}

In Israel, shrill warnings about an imminent "Iranian threat” have observable and definable characteristics. These include the consistent use of statements attributed to anonymous and unverifiable sources usually identified as "high level" diplomatic, military and/or intelligence experts; the frequent circularity of sources in the citation and dissemination of these statements; and the refusal to acknowledge that Iran has any legitimate regional security concerns which play a role in its defense policies. Any Iranian weapons procurement, and the acquisition of any type of nuclear technology, are depicted as having Israel as their primary, even sole, target. Israeli spokesmen almost invariably portray "Iran” as a unitary state-level actor, making no distinction between hardliners and moderates, or between state-sponsored and rogue operations carried out by anyone of Iranian origin.

Iranian rhetoric against Israel during this period (as well as before and after it) has been virulent and incendiary. Recognition of the right of the "Zionist entity" (as Israel is almost always referred to in the Iranian media) to legitimately exist within any boundaries at all, be they those of 1967 or of 1948, is rarely axiomatic or apparent. Israel's existence, as well as its actions, is often depicted as “criminal.” Iranian "satanization” of Israel takes no note of the highly diverse elements of Israel's political culture, which manifest themselves in open, lively debate in the Israeli media, and the ubiquity of criticism of Israeli government actions within Israel from both the right and the left of the political spectrum. No compassion is ever expressed for Israeli victims of suicide bombings or their families. 
Iranian diatribes take place within a long cultural tradition of "conspiracy theories" to explain Iranian failures to achieve and exert its rightful political, military, cultural, and religious superiority. Among the enemies identified by conspiracy theorists as undermining Iran's security and economy, and are often depicted as being in league with satanic forces, have been Freemasons, the Bahais, Jews, the Shi' ite ulama, and the Shah, in addition to Jews and Zionists, as well as European powers, particularly the British and the CIA, who indisputably intervened in Iranian affairs and undermined Iranian sovereignty. An amalgamation of these conspiratorial grievances depicts Israel's existence as well as its actions are depicted as "criminal," irrespective of its boundaries. The "little Satan” incarnates Western encroachment into Muslim lands.

Iran is verbally supportive of the Palestinian cause, although it tends to be cool or even hostile towards the Palestinian leadership. Palestinian actions precipitating the Israeli invasion of Lebanon disastrously impacted the generally peaceful Shia villages along Israel's northern border more than two decades ago, and Palestinian support of Iraq during the Iran-Iraq war, have made Iranians cautious. ${ }^{404}$ It should also be noted that Iranian support of Hizbullah, which has been much more openly acknowledged by the Iranian government than its assistance to the PLO and/or other Palestinian political groups, has had as its primary goal the liberation of Lebanon rather than of Palestine, not only from Israeli occupation but from Syria and from the political domination of Israelibacked Christian forces. Veiled threats of Iranian use of ballistic missiles or nuclear

404. See Fouad Ajami, The Vanished Imam: Musa al Sadr and the Shia of Lebanon (Ithaca, Cornell University, 1986), 200-201. 
weapons in response to an Israeli attack never mention the effect such a counter-attack might have on the Palestinians to whose cause the Iranian government is expressing its inalienable commitment, due to the small size and irregular boundaries between "green line” Israel and the Palestinian communities of the West Bank and Gaza.

The post-September 11 Israeli rhetorical campaign against Iran had three objectives, none of which were new. They had been articulated as policy priorities for at least a decade. What was new were the opportunities for legitimating and achieving them as a concomitant of the U.S. "war against terror.” One of these longstanding objectives was the prevention of normalization, or even of any modest improvement, in relations between the U.S. and Iran. ${ }^{405}$ Another is to depict Iranian instigation and its military and financial support of terrorist organizations as the major barrier to Israel's achieving peace with the Palestinians. This deflects attention from Israeli policies, such as the continued establishment and expansion of settlements in the West Bank and Gaza, and left the “peace process” in shambles. The third goal was, and remains, to encourage the U.S. to use "the war on terror" to either attack Iran and destroy its presumed nuclear capability on its own, or to acquiesce to an Israeli strike against Iran similar to that on the Osiraq nuclear facility in Iraq. That presumption that Iran even had a nuclear weapons program had been based largely on evidence provided by Israel. Iran’s leaders had declared the

405. See Parsi, Treacherous Alliance, 157-257. 
use of such weapon to be un-Islamic. Nonetheless, there was public debate over whether or not Iran should pursue nuclear technology or even weapons. ${ }^{406}$

From the Iranian perspective, the "war on terror" and Bush’s insistence that "you are either for us or against us” offered both dangers and opportunities. The greatest danger was, and remains, that Iran might become its direct target. However, in the immediate aftermath of the events of September 11, "the war on terror" seemed to present potential opportunities for Iran as well. When Bush announced his intention of building a coalition which included "anti-terrorist" Muslim states, it appeared possible that the U.S. might modify its position sufficiently so as to allow for Iranian participation, as well as for the first steps of reconciliation, between the U.S. and Iran. In midSeptember, Iran articulated four demands which would influence its participation in the coalition: 1) the definition of "terrorism" would encompass Israeli actions against Palestinians and in Lebanon; 2) military action in the "war against terrorism” would be conducted under the auspices of the United Nations rather than the United States; 3) the U.S. and Europe would crack down on the activities of the Mojahedin-e Khalq, which, although listed by the U.S., the U.K. and other countries as a terrorist organization, ${ }^{407}$ was raising funds and operating radio and satellite television stations through front

406. Farideh Farhi, “To Have or Not to Have? Iran’s Domestic Debate on Nuclear Options.” In Geoffrey Kemp et.al., Iran’s Nuclear Weapons Options: Issues and Analysis. Nixon Center Monograph, 2001.

407. U.S. State Dept. "Patterns of Global Terrorism."

http://www.state.gov/s/ct/rls/pgtrpt/2000/2450.htm （accessed March 29, 2002). 
organizations in the U.S. and Europe; ${ }^{408}$ and 4) the regime replacing the Taliban would not be hostile to Iran.

The research presented here suggests that the five months between the September 11 events and the aftermath of President George W. Bush's State of the Union address may be viewed as encompassing four distinguishable periods: 1) from the initial responses to the airplane hijackings on September 11 until Israeli Prime Minister Ariel Sharon's meeting with U.S. President Bush on November 7; 2) from Sharon’s departure from Washington until the revelation of the Karine A affair; 3) from the aftermath of the Karine A affair through Bush’s reference to Iran as part of an “axis of evil”; 4) the "postaxis” period (February 1 through the present). In each of these periods, one can observe some potential for rapprochement between the U.S. and Iran. In each of them, Israel provided information, based largely or exclusively on unverifiable and almost always unidentified sources, which (legitimated by subsequent quotation by reliable sources) not only prevented any warming of relations between the U.S. and Iran, but exacerbated tensions between them.

The thoroughness with which Iranian overtures and responses were eventually rejected by the U.S., in good measure due to Israeli prompting, quickly delegitimized them within the Iranian government and strengthened the positions of anti-American hardliners. This not only pushed Iran further beyond the U.S. foreign policy pale, but undermined the domestic political position of Iranians favoring accommodation with the

408. Ali Nuri Zadah, Report, Al-Sharq al-Awsat, Sept. 21, 2001. WNC Doc. FBIS-NES2001-0921. 
U.S. Furthermore, the denunciation of Iran as part of an "axis of evil" has unified Iranians across the political spectrum, blurring the boundaries between hardliners and moderates. Ironically, this in turn vindicates the exponents of the "Iranian threat" in both the Israeli and U.S. governments, who have consistently argued that Khatami was no different than his predecessors, and that nothing less than the overthrow or collapse of Iran’s Islamic regime will transform Iran into a suitable partner for peace and security in the Middle East and Central Asia.

Containment of Iran had been a top priority for Israel since the Rabin administration, and was one of the few things about which he was able to agree with AIPAC (American Israel Public Affairs Committee), the premier U.S. "Israel lobby” who Rabin castigated for meddling in Israel's with the U.S. Immediately after the attacks on the World Trade Center and Pentagon on September 11, a spate of Israeli pronouncements drew upon a decade of declarations of Iranian complicity in terrorist attacks and warnings about the Iranian nuclear threat, to which Israel had directed the attention of U.S. and Russian policymakers for nearly a decade. A war of civilizations had begun, in which Islamic fundamentalist forces had just launched their first strike. The next strike might be a nuclear attack by Iran.

During a stopover in London on his return from a visit to the U.S., where he had been on September 10, former Israeli Prime Minister Ehud Barak told interviewers that he did not know who had carried the attacks, and, while it was "probable" that they had links to bin-Laden, he could not say so with certainty. "The very scale of these acts and the challenge they pose are such that they should evoke a worldwide fight against terrorism” the way Europe had fought maritime piracy, Barak stated. "This effort must 
not be aimed solely at the infrastructures of those we all know: bin-Laden, Hizbullah, HAMAS [Islamic Resistance Movement], the Islamic Jihad and even some of those around Arafat. It must also include the states and leaders that shelter and sponsor them: Afghanistan, Iran, Iraq, to a certain degree North Korea and Libya, Sudan and a few other regimes that play a secondary role. All the world will have to make up its mind, not just in words but also in actions." Barak said the struggle would create "a new and clear demarcation line," which "must not be seen as a Judeo-Christian fight against Islam, because there are many moderate and reasonable leaders in the Arab-Muslim world. But each one will have to consider and choose his camp.”409

Former Israeli Prime Minister Benjamin Netanyahu warned that the New York and Washington attacks could be a harbinger of worse tragedies that could kill millions of people once Iran or Iraq acquired nuclear weapons. Claiming to have warned of such attacks soon after the World Trade Center bombing in 1993, and in his book Fighting Terrorism, Netanyahu called for a coalition against the militant Islamic regimes of “terrorist states like Iraq, Iran, Afghanistan, and the Palestinian entity" that want to “devour the West."410

In the same vein, a histrionic opinion piece in Maariv trumpeted that the world needed "a historic leader," with "superhuman” qualities, who "should bang on tables in Moscow and stop the sale of nuclear know-how and equipment to Iran” and halt the

409. Jean-Marie Colombani, Jean-Pierre Langellier and Georges Marion, "What Ehud Baraq Says About It,” interview. Le Monde, internet version, Sept. 13, 2001. WNC Doc. FBISWEU-2001-0913. 12, 2001.

410. Gil Hoffman, “Netanyahu: World Must Join to Crush Terror,” Jerusalem Post, Sept. 
missile sales of North Korea. "He should destroy the murderous empire of the Taliban and the Ayatollahs.” ${ }^{411}$ The Globes daily business report called for a total cutoff of U.S. diplomatic and commercial ties with Russia, who was providing Iran with materials which were a danger to the entire world: "Russia supplies Iran with nuclear materials that will enable Iran to manufacture nuclear weapons. This isn't a secret. Everybody knows it. So what? Nothing is being done about it. It's crystal clear that if Iran has nuclear weapons, so will Islamic terrorist organizations. Instead of crashing planes into buildings, terrorist organizations may fire missiles with nuclear warheads.” ${ }^{412}$

Globes published an interview with Dan Meridor, long been regarded by some as a rising star in Israel's gerontocratic firmament. His interviewer noted at the outset that Meridor foresaw an apocalyptic battle between good and evil, with a global war ensuing "from Ramallah to Gaza, through the Al-Biqa Valley in Lebanon, the mountains of Iran and Afghanistan, all the way to Manhattan,” between the countries of free world against those "pulling the strings of terror," whoever they might be. "Whoever thought the Palestinian conflict was the source of the scourge of fundamentalist terror realized this week that this was not so." Meridor said. "I think the world will now understand that

411. Shalom Rosenfeld, “Commentary: Historical Leader” Maariv (Hayom Supplement), Sept. 13 2001, WNC Doc. FBIS-NES-2001-0913

412. Editorial, “World Gets a Warning,” Globes, Sept. 13, 2001, WNC Doc. FBIS-NES2001-0913. 
the war is not over what the exact boundaries of the State of Israel should be or where the Palestinian state should be established." ${ }^{413}$

Israel’s Shinui (“Change”) party leader Yosef (“Tommy”) Lapid called the attacks on the World Trade Center and Pentagon the "first course" on the menu of "fanatic Islam" and international terrorism, and noted that "most experts believe that Iran will manufacture nuclear weapons within three or, at most, five years.”414 Another article in the Jerusalem Post the same day (September 14) quoted an unnamed Western diplomatic source as asserting that, in contrast to the 1990 coalition put together by U.S. President George W. Bush's father, which had left Israel out in order to avoid offending Arab sensibilities, the new anti-terror coalition would include Israel as a full partner, which “may allow it to participate in attacks against Iraq, as well as Iran and Afghanistan.»״15

On September 11, Iranian President Khatami condemned the terrorist assault on the United States on Iranian television, stating:

In the name of the nation and the government of the Islamic Republic of Iran I condemn the terrorist operations of hijacking and attacking public places in American cities which have resulted in the death of a large number of defenseless American people. I would like to express my deep regret and condolences to the American nation especially those injured and the families of the victims of these incidents. Terrorism is condemned and the world public should identify its roots and its dimensions and should take fundamental steps to eliminate it. The principled will of the Islamic Republic of Iran's government is categorically

413. Tzvi Lavi, interview with Dan Meridor, Sept. 12, 2001, "We Will Win in the End, And It's A Pity That They Won't Be There,” Globes, Sept. 13, 2001, WNC Doc. FBIS-NES2001-0915.

414. Yosef Lapid, “The Warning,” Jerusalem Post, Sept. 14, 2001.

415. Gil Hoffman, “Gulf War-Style Anti-Terror Coalition to Include Israel.” Jerusalem Post, Sept. 14, 2001. 
following this path and would not stop at any measure to realize this Islamic and humane belief. ${ }^{416}$

Khatami's condemnation of terrorism was not taken at face value by the international media. The French Press Agency (AFP) interpreted "roots of terrorism” in Khatami’s address as referring to "Washington's unconditional support for Israel, which Tehran does not recognize." 417 The London Times reported "a marked divergence between the reformist President Khatami's call for international action to stem terrorist attacks and the tone of the Tehran Times, which concluded that the Bush Administration was paying the price for its 'blind support' of Israel.”418 The Jerusalem Post carried a Reuters report which interpreted Khatami's words as "indicating that Iranian conservatives and reformists are united in calling for the destruction of Israel as the only solution to the Middle East conflict," although "they differ in the strength of their opposition to it and its main backer, the U.S.” The report went on to quote Iranian newspapers that emphasized the role of U.S. "blind support of the Zionist regime," had played in the attacks, but also repeated the hardliner charge that Zionists had carried them out. Nonetheless, the article concluded with the observation that "unlike elsewhere in the region, there have been no

416. "Iran: President Khatami condemns attacks on US cities.” Vision of the Islamic Republic of Iran Network 2, Tehran, Sept 11, 2001 , 1800 gmt. BBC Monitoring Middle East, BBC Worldwide Monitoring. Online, Lexis-Nexis Academic Universe.

417. Jean-Michel Cadiot, "Iran Condemns Terror Wave in US but Blames Washington's Israel,” AFP, Sept. 12, 2001. Online, Lexis-Nexis Academic Universe .

418. Stephen Farrell, “Middle East Split over Attack Reaction.” The Times (London), September 13, 2001, Online, Lexis-Nexis Academic Universe. 
public displays of joy in Iran, where Khatami won a landslide reelection promising to improve relations with the outside world."419

The day after the terrorist attacks, Iran’s majority Mosharekat (“Participation”) party issued a condemnation of them, saying they "displayed the furthest depth of the catastrophe that terrorism can inflict against humanity in any corner of the globe," and expressing “deepest regret and sympathy with the American nation and particularly the bereaved families of the incidents' victims.” The Iranian nation, itself a major victim of terrorist attacks, acutely felt the pain inflicted against others, and believed it to be a joint task for all nations and world governments to cooperate in a campaign to uproot terrorism. Nevertheless, the Mosharekat party criticized the U.S. government "for staunchly supporting the biggest state sponsor of terrorism in the world, Israel, and defending the unjustifiable terrorist moves of that terrorist entity openly." ${ }^{420}$

A compendium of views expressed by Iranian politicians across the political appeared in the Teheran news daily Siyasat-e Ruz on September 13. None condoned the attacks. Reactions ranged from denouncing the "Black Tuesday" events in the U.S. as unjustifiable criminal acts that could only be unequivocally and universally condemned, to pointing to the unprecedented need for the "dialogue of civilizations" called for by President Khatami, to sympathizing with the American people while suggesting that they ask their political leaders why the U.S. had inspired so much hatred and the need to find 2001.

419. Reuters, “Iranian Media Blame US-Israel Ties for Attacks” Jerusalem Post, Sept. 13, 420. “Iran's Mosharekat Party condemns terrorist attacks,” Communique, Sept. 12, 2001. WNC Doc. FBIS-NES-2001-0912 
the "root cause of such events." As noted earlier, ex-parliamentarian Mohammad Javad Larijani, a former Deputy Foreign Minister who had lost his Majlis seat to reformists but retains considerable influence in foreign affairs, said his first guess was that perpetrators had to have been agents of the Zionists and the Israeli Mossad, since only they would have had access to the resources needed to carry out the attack and because the consequences of the attack favored Israeli interests. "In circumstances in which that regime has been isolated in terms of world public opinion, this measure draws the attention of the world away from their crimes and to something else, and, in a way, creates the possibility of carrying out publicity against the wronged Palestinians.”421

The possibility that the "war against terrorism” might provide an opportunity for reconciliation between Iran and the U.S. began to be discussed in Iran within days of the September 11 events. Political caution is evident in the way the Iranian News Agency (IRNA) disseminated the idea by reprinting a report published in the London Times that pointed out the positive reception that Iran's response the events of September 11 had received from the U.S. State Department, which was "willing to explore the possibility of welcoming Iran into an international coalition to fight terrorism," and "paradoxically, open the way for reconciliation between Washington and Tehran.” While western military forces would not be permitted to use Iranian territory for any U.S.-led operation in Afghanistan, Iran could quietly provide valuable intelligence through third countries such as Russia, other Islamic states, or members of the Non-Aligned Movement.

421. “America and World Following Black Tuesday,” Sept. 13, 2001, WNC Doc. FBISNES-2001-0925. 
The IRNA article also noted the Times had reported that an obstacle to cooperation was the likely Israeli opposition in Washington, but also that the European Union, particularly Britain, might be influential in convincing the U.S. towards a broader policy. An unnamed European diplomat was quoted as stating that "The (U.S.) 82nd Airborne and Iran's Revolutionary Guards have similar views on the Taliban.”422

The possibility and desirability of reconciliation with the U.S. had been a contentious issue in Iran even before the events of September 11. Less than a week before the attacks in the U.S., Mohammad Javad Larijani had said in an interview that "normalization" of relations between the U.S. and Iran was unlikely. "When the Americans were showing a green light they wanted to discuss three issues. One was Iran's support for terrorism, which is related to our support for the Palestinians, because they consider the Palestinians to be terrorists. Second was the issue of human rights and the third issue was the production of nuclear weapons and weapons of mass destruction.” Interaction with the U.S. might be possible to discuss issues such as "the future of Afghanistan, the campaign against drugs, the problem of refugees, and the future of important international waterways from the environmental aspect," if the two countries "can discuss issues at the same level."

Larajani asserted Iran's “absolute right” to have access to nuclear weapons if the U.S. and other nations do: "If in disarmament talks the world can present a timetable for the elimination of atomic weapons we too are willing to sign and not pursue it. But at

422. “US Tragedy Opens Way For Reconciliation With Iran - Report” Iran National News Agency (IRNA), Sept. 17, 2001. Online http://www.irna.com/en/world/010917144903.ewo.shtml (accessed Apr. 4, 2005). 
present they are not willing and, in addition, their lackeys in the region such as Israel and others also possess these weapons.” ${ }^{423}$ On September 13, when asked whether Iran would change its positions on Middle Eastern affairs to clear its name in American opinion, Larijani responded that its policy on Palestine "is the most honorable part of Iran's foreign policy... It is our right to support the Palestinians by any means." ${ }^{2424}$

On September 21, the London-based Arabic newspaper Al-Sharq al-Awsat reported that, according to an Iranian source, a meeting between a senior European diplomat and a senior official at the Iran's National Security Higher Council had taken place earlier in the week to discuss the measures that would be taken by the U.S. and its allies "against terrorism and the countries that harbor terrorism at various levels." The European diplomat said Iran would have to be "frank and transparent in condemning terrorism and supporting the international movement to uproot terrorism wherever it might be.” This source said that meetings had also taken place between Iranian government representatives and officials from Canada and Europe during the previous week, during which the Iranians asked whether the United States, Canada, and European states harboring members of the Mojahedin-e Khalq Organization would be prepared to put an end to MKO activities of return for Iran's support of the anti-terrorism alliance. A confidential letter to a National Security Higher Council official from one of his

423. "The West had unrealistic expectations of Khatami," (interview with Mohammad Javad Larijani), Resalat, Sept. 6, 2001. WNC doc. FBIS-NES-2001-0919.

424. "Mr. Khatami Should Revive Relations With Egypt," (interview with Mohammad Javad Larijani), Resalat, Sept. 6, 2001. WNC doc. FBIS-NES-2001-1001. 
European counterparts hinted that the war on terrorism would "include all the organizations that rely on terrorist operations" and the MKO was among them. The article quoted an unidentified reformist deputy in the Iranian Majles as saying:

"Despite attempts by the Zionist lobby and figures like Senator Lieberman and Henry Kissinger to include Iran among pro-terrorist countries, President George Bush's Government refused to point a finger at Iran on account President Khatami's immediate expression of sympathy and public condemnation of terrorism, and because Iranian officials, the Iranian press, and 'the people on the street' had made 'a good impression on the American people and government which helped change the atmosphere in Tehran as well." 425

The same source confirmed a report published in Al-Sharq al-Awsat a few days earlier concerning “a decision by the Iranian revolution Supreme Leader Ali Khamenei to give Khatami a free hand to run foreign policy, particularly in terms of the United States” and had "practically recognized Khatami's role in forming the general guidelines for Iran's foreign policy.” The article noted Khamenei’s well known enmity towards the Taliban and its leader, Mullah Omar, who "had described those who belonged to the Shiite sect as rejects. Omar had ordered the sectarian cleansing in Bamian and Mazar-e Sharif, which resulted in the death of thousands of Shiites..."426

Initially, Israelis had assumed they would be welcome partners in the war on terrorism. "I believe that together we can defeat these forces of evil," Prime Minister Ariel Sharon had declared in a televised statement on September 11."427 A week after the attacks, however, Efraim Inbar, Director of the Begin-Sadat (BESA) Institute of

425. Ali Nuri Zadah, Report, Al-Sharq al-Awsat, Sept. 21, 2001. WNC Doc. FBIS-NES2001-0921.

426. Zadah, Al-Sharq al-Awsat, Sept. 21, 2001.

427. Shalev, Forward, Sept. 14, 2001. 
Strategic Studies at Bar Ilan University, told a Jerusalem Post radio that the inclusion of Muslim states in the U.S. coalition against terrorism, among them Iran, might require some "compromises" on the part of the U.S., although he did not feel this would necessarily preclude Israel's participation.” ${ }^{428}$ Nevertheless, a cable to the Foreign Ministry from an identified senior diplomat expressed concern that the U.S. media was beginning to link Israeli policies and Israeli-Palestinian conflict to the attacks in New York and Washington, and predicted that "this topic will gain currency on the U.S. agenda as the U.S. attempts to build an anti-terror coalition develop, and it becomes clear that Israeli and U.S. interests on the matter are not identical." ${ }^{429}$

Subsequent reports in the Israeli media reflected increasing apprehension that the participation of Muslim countries would not only restrict Israel's membership in the antiterrorist coalition, but might pressure the U.S. to demand Israeli concessions to the Palestinians. Two weeks after the Sept. 11 attacks, Alon Pinkas, the Israeli Consul in New York, warned the Foreign Ministry that a "paradigm shift" was taking place in American thinking that might raise questions about the U.S. role in the Israeli-Palestinian conflict, while editorials and news analysis critical of Sharon which were appearing in major American newspapers might be early warning signs of an anti-Israel backlash. While Foreign Ministry officials accused Pinkas of being an "alarmist," it was noted that 2001.

428. Ephraim Inbar, interviewed by Miriam Shaked, Jerusalem Post Radio, Sept. 17,

429. Herb Keinon, “US May See Israel as Obstacle to Coalition,” Jerusalem Post, Sept. 21, 2001. 
Israel did not appear on televised maps of the "coalition against terror", and that none of the 27 terrorist-supporting organizations whose assets were being frozen by President Bush were linked to terror against Israel. ${ }^{430}$

British Prime Minister Tony Blair's phone call to President Bush to inform him about a "remarkable conversation" he had had with Iranian President Khatami, and that British Foreign Minister Jack Straw’s would be visiting Teheran Sept. 25-27, provoked considerable consternation in Israel. The Jerusalem Post reported that the U.S. "has no formal links with Teheran but regards Iran as a critical element in legitimizing the coalition and cloaking it in Islamic credibility." ${ }^{431}$ That same day, another article highlighted that a senior IDF intelligence officer thought Iran "could have had a hand" in plotting the attacks on the U.S. "We don't have any information to support the possibility that Iraq is part of the plot,” the unidentified officer was quoted as saying. "But we can't say the same for the Iranians. They are very deeply involved in everything that carries the label of Islamic radical terrorism.” Iran, Osama bin Laden, Hizbullah, and Hamas were all from the same school of thought, he added, but "Iran is the only country in the world that actually adopts this ideology and is working on its capabilities to get hold of weapons of mass destruction and long-range missiles. Together with this ideology and these sort of threats, you can understand the kind of threat the free world and Israel is

430. Susser, Oct. 22.

431. Douglas Davis, “British FM to Iran for Historical Visit” Jerusalem Post, Sept. 23, 2001. 
facing." ${ }^{432}$ A non-scientific poll on the Jerusalem Post website that asked, "Do you think Iran was involved in any way in the WTC attack as Israel is suggesting?” found that $81 \%$ of the 12,858 respondents agreed. ${ }^{433}$

Former Israeli Prime Minister Netanyahu, in Washington to address the US House of Representatives Government Reform Committee on Sept. 24, linked growth of the terror network of those responsible for the attacks directly to developments in Iran: he said the Khomeini revolution and the establishment of a clerical Islamic state in Iran had "created a sovereign spiritual base for fomenting a strident Islamic militancy worldwide, a militancy that was often backed by terror." ${ }^{434}$ Israeli President Katsav denounced the policies of several European states regarding global terrorism, saying they were dangerous because they legitimize the murder of innocent civilians. Those who condemn Israel's actions to foil terrorism, he declared, encourage terrorist activities. ${ }^{435}$

Transport Minister Ephraim Sneh, a Labor Party member of Israel's coalition government and retired general who had once served as deputy defense minister, complained on Israeli radio that Iran "will buy itself legitimacy at very little expense.” After the campaign against Bin Laden was over, Sneh said, "[Iran] will continue

432. Arieh O’Sullivan, “IDF: Iraq not involved in attacks; Iran maybe.” Jerusalem Post, Sept. 23, 2001.

433. Online Poll, Jerusalem Post, Sept. 23, 2001. http://www.jpost.com/Editions/2001/09/23/ (accessed Sept. 26, 2001.)

434. Benjamin Netanyahu, "We Are All Targets" (transcript of remarks to US House of Representatives' Government Reform Committee), Jerusalem Post, Sept. 24, 2001. 25, 2001.

435. “Katsav: Those who Condemn Israel, Encourage Terrorism.” Jerusalem Post, Sept. 
its support for terrorism, but with a kosher certificate from the United States.”436 Sneh called Straw's visit a "stab in the back” to Israel. Sneh denounced Straw’s statement as “an obscenity”, published in an article he had written for an Iranian newspaper just prior to his arrival, that "One of the factors that helps breed terror is the anger that many people in the region feel at events over the years in the Palestinian territories"437 and Straw’s scheduled meetings with Prime Minister Ariel Sharon and President Moshe Katsav were cancelled over his remarks. After a 15 minute phone conversation between Blair and Sharon, his meeting with Straw was reinstated. ${ }^{438}$

Sneh's displeasure served to reinforce the position of Iranians favoring rapprochement. A reformist editorial columnist suggested that, if Straw's visit were a stab in the back for Israel, then it should be welcomed as a measure that would strengthen Iran. "(I)f the visit has threatened Israeli interests in the region and has expelled that country from the center of European diplomacy in the region, then would not the other side of this fact be fresh opportunities being available for Iran to exploit and for it to make use of opportunities for furthering Iran's foreign policy?” Rather than the rightwing press viewing Straw's visit from the perspective of strengthening the reformist position, “(t)hey should, rather, think in terms of its effective and positive consequences

436. Greg Myre, “Israel: Anti-terror Coalition Should Target Iran, Syria.” Jerusalem Post, Sept. 25, 2001. Online. http://www.jpost.com/Editions/2001/09/25/LatestNews/LatestNews.35365.html. (accessed Sept 27, 2001).

437. Steve Weizman, Associated Press, "Sneh Launches Blistering Attack on British FM,” Jerusalem Post, Sept. 24, 2001.

438. “Israel Criticizes 'Distasteful' Remarks by UK's Straw ahead of Visit.” London Press Assoc. Sept. 25, 2001. WNC Doc. FBIS-WEU-2001-0925. 
for maintaining the dignity and authority of Iran in the region and in the international arena.”439

The motives for Straw's visit were a topic of considerable speculation in the Iranian media, the first by a British foreign minister since the 1979 Islamic Revolution. “According to the British there are no eternal friends or foes in politics," explained Iranian journalist and international relations commentator Sa'id Leylaz in an interview the day before Straw’s meeting with President Khatami and Foreign Minister Kharrazi. “There are no eternal interests and if necessary two sides can become friends, foes, or terrorists." Leylaz noted that the idea of improving relations with the West had many enemies in Iran. “From the extremists' point of view, as long as there are full-fledged Zionists in the US lobbies we will never want to establish relations; and we will witness many obstructions when it comes to establishing such relations.” Nevertheless, he viewed relations between Iran and the U. S., on the whole, as being "more positive and increasing.” Relative social and political calm after the Iranian elections and improvements in the economic situation had led to "the path of strategy" and "a more moderate stance that moves in the direction of improved relations with the West and the United States.” Leylaz spoke approvingly of the official Iranian position that both condemned terrorist acts and insisted that the campaign against terror be carried out

439. "Britain, Israel and the stances of Iranian rightwing newspapers.” Nowruz, Sept. 25, 2001. WNC Doc. FBIS-NES-2001-0926 
under the auspices of the UN, and opined that Iran should rush into a reconciliation with the U.S. ${ }^{440}$

The first evening of Straw's visit, Iranian television reported that he had expressed his approval of President Khatami’s call for a dialogue of civilizations, describing meetings of intellectuals and religious leaders as "effective and productive" in stopping a confrontation between Islam and the West. Khatami, while expressing understanding for the American situation in the face of the recent incidents, in spite of U.S. indifference to, even possible assistance to, terrorist attacks in Iran, declared that "any move in the region which ignores the role of Iran in the stability of the region will add to the problems.” The Iranian president also referred to "the Zionist regime's moves aimed at creating a confrontation between the world of Islam and the West.” 441

But Straw aroused Iranian ire when, in response to remarks by Iranian Foreign Minister Kharrazi in which he referred to the Israeli regime as "racist," Straw declared that "Britain does not accept the terms racist or Zionist being used to refer to Israel and fully believes that Israel has the right to live,” adding, “The Israelis have also suffered from terrorism and Britain believes that we should do something along with Arafat to implement the peace process." ${ }^{442}$ Kharrazi countered that "The Zionist regime must not tarnish the image of Muslims...rather, the recent incidents must be turned into an

440. “The Zionists Do Not Want Iran and America To Forge Ties.” Towse'eh, Sept. 24, 2001, WNC Doc. FBIS-NES-2001-1111.

441. Tehran Vision of the Islamic Republic of Iran, Network 1 in Persian, 1530 GMT Sep 25, 2001. WNC Doc. FBIS-NES-2001-0925.

442. "British Foreign Secretary's Doubletalk,” Jomhuri-ye Eslami, Sept. 26, 2001, WNC Doc. FBIS-NES-2001-0927. 
opportunity to launch a 'relentless assault' on terrorism.” Expressing Iran's willingness to expand its ties with the UK, Kharrazi added, “Once Washington's hostile policies towards Tehran are changed, and Washington takes the initiative to establish relations based on mutual respect and equality, then Teheran will be ready to review its (now-frozen) ties with the U.S." ${ }^{443}$

In a sermon at Friday prayers at Tehran University on Sept. 28, Expediency Council Chairman Akbar Hashemi-Rafsanjani, Iran’s former president, announced that "Despite all our differences [with the USA], if America decides not to impose its own will ...we are ready to join the anti-terrorism coalition under the umbrella of the United Nations..." ${ }^{444}$ By the end of September, the advantages (and disadvantages) of the improvement relations between Iran and the West (particularly the U.S.) to achieve Iranian foreign policy goals, were being discussed widely. Commenting on Iran's diplomacy in light of recent events, Mohammad Ali Kuzegar observed, "What we have witnessed in the recent days indicates the importance of Iran's special position in international equations and relations... he said: A nation does not often encounter such historic opportunities." 445 Vice President Mohammad Reza Tajik declared, "The

443. "Straw describes meeting with Kharrazi 'historic'” (sic). IRNA, Sept. 25, 2001, WNC Doc. FBIS-NES-2001-0925.

444. "Second sermon from the Friday prayers at Tehran University delivered by Expediency Council Chairman Akbar Hashemi-Rafsanjani on 28 September.” Voice of the Islamic Republic of Iran Radio 1, Sept. 28, 2001, WNC Doc. FBIS-NES-2001-0928.

445. "Shahryar: No regional coalition could be formed without Iran's participation.” Aftab-e Yazd, in September 29, 2001. WNC FBIS-NES-2001-0929. 
situation presents opportunities and in the context of these events we could resolve the problem of Iranian terrorism, implement a policy of detente towards the West, pursue a policy of dialogue, present a more acceptable face of Iranian society to the world, promote the role to the United Nation and have a greater say in international affairs." ${ }^{446}$ Straw's visit to Israel on Sept. 26 did not elicit nearly as positive an assessment from Israeli government officials. In spite of Straw’s protestation, “I stand very firmly against the terrorism which the Israeli people have suffered. I've never, ever dreamed of calling the Israeli people terrorists. I stand fully behind them,” President Katsav refused to meet with Straw. Foreign Minister Shimon Peres cancelled a dinner that was to have been held in Straw's honor but met with him briefly. During their meeting, Peres emphasized to Straw that Iran funds and directs Hizbullah, publicly calls for the destruction of Israel, and is developing nuclear weapons. In the hands of extremist Ayatollahs, Peres said, these weapons are "a danger to the entire world." ${ }^{447}$ No mention of Straw's defense of Israel in Teheran was noted in the Israeli media. Instead, the editor of the bi-weekly magazine Jerusalem Report David Horovitz, whose views generally reflect a thoughtful Israeli centrist postion, accused Straw of "intimating...that terrorist attacks against Israel could somehow be legitimized.” Characterizing Straw’s Iranian trip as the "craven, misguiding courting of the very perpetrators of the crime they are seeking

446. "Tajik: The policy of detente towards the West must be implemented" Entekhab, Sept. 30, 2001, WNC Doc. FBIS-NES-2001-0930.

447. Herb Keinon, “After call from Blair, Sharon meets with Straw.” Jerusalem Post, September 26, 2001. 
to eliminate," as well as "a virtual invitation to terrorists to carry out more crimes," Horovitz said that was “no surprise that Iran has now rejected Straw’s advances...”448

Dozens of articles and editorials in the from various perspectives in the Iranian press during the first two weeks in October offered reasons Iran should not join the antiterror coalition unless it was under the auspices of the U.N. The Iranian newspaper Siyasat-e Ruz prefaced a poll of the opinions of several Majlis members with both the pragmatic emphasis across the political and factional spectrum on "the necessity to maintain the independent stance of the Islamic Republic of Iran in the face of world developments and the imperialist steps which the US takes in order to secure its interests in the region” appeared alongside the recurrent charge of Zionist complicity in the attacks, which were being unfairly blamed on Muslims: "While the accusing fingers of the Western and Zionist media are pointed at Usamah Bin-Laden and a number of Islamic groups as the agents for the terrorist attacks on the cities of New York and Washington, each day more undeniable evidence is being disclosed with regard to the possibility of the interference and responsibility of the Zionist circles and intelligence agencies in the incidents in America.” The reasons given by the Majlis members identified by name in the article included, in various formulations, suspicion of American and British motives and Iran's insistence that the "war on terror" be led by the U.N. ${ }^{449}$

448. David Horovitz, "From the Editor: The Wrong Coalition.” Jerusalem Report, Oct. 22, 2001, 4. [The Jerusalem Report goes to press at least 2 weeks before its cover date.]

449. "Iran: Paper views reasons for not joining US-led anti-terrorism coalition.” Text of report on interviews with Majlis deputies by the "Political group": "Why is Iran not taking part in America's anti-terrorism coalition?” Siyasat-e Ruz, Tehran, in Persian Oct 7, 2001 p 3. BBC Monitoring, BBC, Oct. 16, 
During the United Nations debate on "measures to eliminate international terrorism” which took place Oct. 1-5, Iran’s Deputy Foreign Minister, M. Javad Zarif, asserted that "The Islamic Republic of Iran is fully prepared to contribute actively to a UN-led global campaign against terrorism.” Zarif noted that President Khatami had proposed in a letter to the Secretary-General on September 16 that negotiations should begin on "practical and serious global policies and strategies to eradicate the menace of terrorism, and that a 'Global Summit' be convened at earliest possible date to show the international political will to uproot terrorism. Iran's position was that the General Assembly should consider a multi-faceted approach to terrorism which would include a guidelines for "a rational and rule-based approach across the board," so that no terrorist could find refuge or support in any member of the international community, and articulate objective single-standard criteria to identify and combat terrorism in the international community regardless of its victims or culprits. “(T)he credibility of the campaign against terrorism is seriously undermined when policies and practices designed to instill terror and fear among the entire Palestinian people receive acquiescing silence, while resistance to foreign occupation and state terrorism is conveniently demonized.” 450

Yehuda Lancry, Israel's permanent representative to the UN, defined terrorism in his statement as "the indiscriminate murder of innocent civilians to advance political or

2001.http://disc.server.com/discussion.cgi?id=61429\&article=13261\&date_query=1003280847 (accessed Oct. 17, 2001).

450. Statement by M. Javad Zarif Deputy Foreign Minister of The Islamic Republic of Iran, UN General Assembly, "Measures to Eliminate International Terrorism," Afternoon Plenary, Oct. 2, 2001. http://www.un.org/terrorism/statements/iranE.html. (accessed Oct. 4, 2001). 
religious objectives," no matter how its apologists otherwise attempt to label it. "There has never been a terrorist group that did not believe that the ends justify the means," Lancry declared. "These ends are typically articulated in terms of rights—but rights without any corresponding responsibilities, so-called rights which permit indiscriminate murder with impunity, so-called rights which clearly defy unequivocal legal obligations and historical commitments." In a veiled reference to Iran, Lancry stated, "Certain regimes in the Middle East and elsewhere have granted terrorists safe harbor, supplied them with weapons and training grounds, and provided the financial backing for the perpetration of thousands of attacks on innocent civilians. Through their support, both active and tacit, these regimes have declared themselves the allies of terrorism, and bear no less responsibility than the terrorists themselves.”451

The passage of a weak resolution that did not define terrorism, along with the decision of the U.S. to launch a military offensive against Afghanistan under its own leadership immediately upon conclusion of the U.N. debate, were denounced in the Iranian press across the political spectrum, in tones of pragmatic reflection: U.S. actions against the people of Afghanistan were contrary to international law, and while there were good reasons for Iran to favor an Afghan regime other than the Taliban, blatant U.S. military intervention to replace it brought up Iranian memories of the American overthrow of Mohammed Mossadeq’s government in June, 1953. The imminent prospect

451. Statement by Ambassador Yehuda Lancry, Permanent Representative of Israel to the United Nations, UN General Assembly, "Measures to Eliminate International Terrorism," Afternoon plenary, Oct. 4, 2001, Online. http://www.un.org/terrorism/statements/israelE.html (accessed August 29, 2003). 
of U.S. air strikes against neighboring Afghanistan was unappealing but inevitable. Iranian political leaders spoke cautiously, and newspaper articles and editorials clearly indicated that no one wanted to give the U.S. any pretext for striking at Iran. One of many astute commentators put Iran’s dilemma particularly succinctly:

The American expedition to the region, in the name of the "war against terrorism," will be a long-term action, and afterward, we will unfortunately witness America's more pronounced and serious participation in the determination of regional policies. The unpleasant effects of this presence on our political or economic national interests are obvious as well...Given the geopolitics of the critical nature of the region our country is a part of, it is expected that our neighbors will become either bases for America, or targets of its deadly attacks. And it seems the outcome of this situation is to put Iran under political, military, and economic siege by the most powerful country in the world. ${ }^{452}$

Meanwhile, Israeli President Ariel Sharon, under the escalating pressure of almost daily suicide bombings in Israelis, and the mysterious explosion of an Siberian aircraft whose passengers were almost exclusively Russian emigrants to Israel, unleashed a harsh diatribe against the U.S. and European efforts to forge an anti-terror coalition which included Israel's enemies but not Israel: "Do not repeat the dreadful mistake of 1938, when enlightened European democracies decided to sacrifice Czechoslovakia for a convenient temporary solution. Do not try to appease the Arabs at our expense. This is unacceptable to us. Israel will not be Czechoslovakia. Israel will fight terrorism.” All attempts to reach a cease-fire with the Palestinians having failed, Sharon announced he was sending Israeli security forces into action against Palestinian terrorism. Receiving no 
support from the international community for its anti-terrorism stance, Sharon asserted, "We can rely only on ourselves. And from today forward, we will only rely on ourselves.” 453

One Israeli commentator observed that Sharon had not only withdrawn from the cease-fire with the Palestinians but "he also declared political war on the United States. Not just war, but a world war!” Accusing the Americans of deliberately stabbing Israel in the back, and of selling out Israel in order to appease the Arabs after insisting Israel was under no US pressure, "suddenly we are back in 1938 on the eve of the Holocaust with Arafat and not only Bin Ladin but also the accursed Hitler and Bush-as one is given to understand-in the form of Neville Chamberlain...” While this rhetoric "according to which the satanic Munich Agreement is absolute evil," and which represented "the ultimate propaganda tool against all villains, be they domestic or foreign,” might reinstate Sharon in the graces of Israel’s right wing and among American Jewry, giving free rein to the IDF to expand the fighting against the Palestinians would be viewed by the Americans "as deliberate sabotage of their efforts to establish a coalition with the Arab world." 454

453. Arieh O'Sullivan, "Sharon: We Won't be Another Czechoslovakia.” Jerusalem Post, October 5, 2001. http://www.jpost.com/Editions/2001/10/05/News/News.35755.html (accessed Oct. 6, 2001).

454. Hemi Shalev: “Volcanic Eruption” Maariv, Oct. 5, 2001. WNC Doc. FBIS-NES2001-1006. Another commentary in the same mainstream Israeli Hebrew language publication criticized the "amazing ability" of both the U.S. and Israel "to hit the weak with one hand, and call for help with the other." The author suggested that "the United States wiping out entire villages in Vietnam and whole towns in Japan, and still believing in all its heart that it is the moral pillar of the Western world” and the comparison of Israel to Czechoslovakia-in which "the Palestinians, with their 180 mortars and another 40,000 rifles, are the strong ones and we are the weak" — had "an enviable narcissistic quality—always being right, always being the just." 
In a similar vein, an editorial in Kayhan International noted with satisfaction that Sharon's invective was an indication of "the growing chasm between the United States and its illegitimate protégé in the Middle East, the Zionist regime.” This chasm, although it might be small at the moment, was sure to grow as the American people realize the heavy price that their country was paying for its support of Israel. There was no comparison between the mighty Nazi empire and the Arab Muslims Israel faces, nor could "the Zionist entity which has amassed huge stockpiles of nuclear warheads, biological weapons and weapons of mass destruction” be compared to Czechoslovakia. "Despite the propaganda of the Zionists in the United States... the American people will begin to see through the propaganda that they are being fed everyday by Jewishcontrolled mass media.”455 Two days later, an Iranian news report said that although the Bush administration only mildly criticized Sharon's outburst, and White House spokesman, Ari Fleisher had said that Sharon's statement was unacceptable because Israel has no stronger ally in the world than the U.S., there were signs that "Mr. Bush and his government have realized that extremism doesn't just originate within the Arab world.” The editorial alluded to British Foreign Minister, Straw’s "now famous statement upon his arrival in Tehran that the West understands and fully comprehends the position and sensitivity of the Muslim world toward the Palestinian issue,” and U.S. Defense Secretary

One might even conclude, the author wrote, that "the major reason for this deep friendship between the United States and Israel is that both countries totally lack self-awareness, that it is a romantic rendezvous between two countries suffering common psychological flaws." See Nir Bar'am: "Look at Yourselves,” Maariv, Oct. 5, 2001. WNC Doc. FBIS-NES-2001-1014.

455. Abolhassan Sobhani ,"Viewpoint: Growing chasm," Keyhan International, Oct. 6, 2001. WNC Doc. FBIS-NES-2001-1012 
Donald Rumsfeld's skipping a stop-over in Tel Aviv, a few days earlier while visiting five other nations in the Middle East and Persian Gulf. ${ }^{456}$

The Oct. 17 assassination of ultra-nationalist Tourism Minister Rehavam Ze'evi, a retired general and head of the far right National Union-Yisrael Beiteinu ("Israel our home”), by Palestinian gunmen took place just a few hours before his resignation as cabinet minister, in protest of the withdrawal of Israeli defense forces (IDF) from two Hebron neighborhoods, ${ }^{457}$ and added to Sharon's outrage as well as his political headaches. A meeting of the Israeli cabinet debated what "message" ought to be disseminated abroad concerning Israel's attitude towards Arafat and the Palestinian Authority, in light of the Ze'evi assassination: Was Arafat a criminal and a terrorist, or was he still a potential peace partner? Foreign Minister Shimon Peres proposed that Israel affirm its agreement with U.S. aims in the "war on terror," and Prime Minister Sharon added that if the PA does not extradite the Popular Front for the Liberation of Palestine, who claimed credit for carrying out the assassination, or dismantle Palestinian terror organizations, "Israel will view the PA as an entity that supports and harbors terror, and will deal with it according to the international norms being employed today against states harboring terror.” According to Housing Minister Natan Sharansky, many of the

456. Editorial: "Sharon in trouble." Iran News (Internet Version-WWW), Oct. 8, 2001, WNC Doc. FBIS-NES-2001-1008.

457. Etgar Lefkovits, “Rehavam Ze'evi Assassinated.” Jerusalem Post, October 18, 2001. http://www.jpost.com/Editions/2001/10/18/News/News.36446.html.(accessed Oct. 19, 2001.) 
cabinet ministers at the meeting agreed that "the PA should be presented in the US as 'Israel's Taliban,' which gives aid and succor to terrorists." ${ }^{\text {,58 }}$

But Sharon's domestic priorities—containing the wrath of Israel's far right who considered him too soft on the Palestinian as well as the center of Israel's political spectrum, stunned at the first death of an Israeli cabinet minister at the hands of Arabswere on a collision course with growing American concern about how Israeli actions might affect the dynamics of the U.S. war against terror. Israeli incursions into Ramallah and Jenin were "not helpful" and "complicated the situation," according to State Dept. spokesman Phil Reeker, who also called on the PA to permanently halt terrorist attacks against Israelis and to bring Ze'evi’s assassins to justice. ${ }^{459}$

An opinion piece by Hebrew University History Professor Robert Wistrich appeared alongside the coverage of Ze'evi funeral orations and the cabinet debate over how to best frame Israel's position vis-à-vis the PA and Arafat in light of the Ze'evi assassination in the Jerusalem Post. Invoking the now ubiquitous "clash of civilizations" argument, Wistrich, author of the newly published Hitler and the Holocaust, said it was no accident that New York, "the financial center of the Western world, but also the largest Jewish city on the planet” was the target of the Sept. 11 attacks, nor was it by chance that "Osama bin Laden and the myriad groups that support him see their struggle

458. Herb Keinon, "Ministers Disagree on How to Portray Arafat, PA Abroad." Jerusalem Post, Oct. 19, 2001.

http://www.jpost.com/Editions/2001/10/19/News/News.36560.html (accessed Oct. 20, 2001).

459. Janine Zacharia, “US Urges Restraint, Detention of Ze'evi's Killers,” Jerusalem Post, Oct. 19, 2001. http://www.jpost.com/Editions/2001/10/19/News/News.36561.html (accessed Oct.23, 2001). 
as one against the 'Crusaders' (meaning the capitalist, Christian West) and the 'Zionists' (meaning international Jewry)." Not Zionism, not colonialism, nor even the "Palestinian question” was the problem Muslims faced, but "the totally anachronistic concept of 'Holy War' and their refusal to come to terms with modernity:

What a theater of the absurd it is when the godfathers of terrorism are courted by the West to join the great coalition against terror! When Iran, Syria, Pakistan, the PLO and others have to be on board and part of the banquet, but Israel (the prime victim of this brutal campaign for so many decades) is treated as a pariah state to be kept in hiding and periodically scolded for "excessive use of force" when it seeks to defend its own citizens from murder. ${ }^{460}$

Back in Iran, an editorial in the Khomeinist-conservative Jomhuri-ye Eslami still argued that the Sept. 11 attacks were "complex plots that the Zionists have come up with in a bid to ensure the survival of the cancerous cell of the Israeli regime.” Also denounced were the Taliban and Bin-Laden, for considering themselves to be the true voice of Islam and believing anyone who is not with them belongs to the camp of the infidels. "Created and nurtured by the Americans themselves... their sell-by date has now expired, [and] America is now prepared to sacrifice them, in a bid to find someone to blame for the internal crisis it has been encountering since the events in New York and Washington on 11 September and to resolve the dire straits both Israel and the U.S. find themselves in as a result of the Intifadah.” They now were giving the Western media the opportunity to equate Islam with terrorism and to suggest that "the war in Afghanistan is in effect a war

460. Robert S. Wistrich, “It is a Clash of Civilizations,” Jerusalem Post, Oct. 19, 2001, Online. http://www.jpost.com/Editions/2001/10/19/Opinion/Opinion.36543.html (accessed Oct. 28, 2001). 
between the opponents and supporters of terrorism. However, we all know that the reality is something else." 461

Joining a meeting between Israeli Foreign Minister Shimon Peres and National Security Adviser Condoleezza Rice, President Bush reportedly complained that, since the Ze'evi assassination, Israel "appears to have gone overboard." According to Peres, the impression Israel was launching a full-scale war on the Palestinians might impede its ability to carry out the U.S.-led war on terrorism. Middle East violence "was making it more difficult to keep the US-led anti-terrorism coalition together." ${ }^{462}$ Bush called for Israeli withdrawal from Palestinian areas, but gave no specific timetable for Israeli withdrawal. Peres responded with five requests of the U.S.: "Continue to press Arafat to live up to his commitments; use its influence to prevent anti-Israeli motions in the UN Security Council; add certain anti-Israel terrorist groups to those being targeted; do not surprise Israel; and warn Syria to keep the northern border quiet.”463

An unidentified diplomatic official in Jerusalem told the Jerusalem Post that "We misread the expected American reaction. Rather than publicly coming down hard on the Palestinians, the U.S. came down hard on us, saying that first we should leave the territories, and then they will deal with the Palestinians. We expected them first to come

461. “Awakening Call for Muslims,” editorial, Jomhuri-ye Eslami (Internet VersionWWW), Oct. 16, 2001.WNC Doc. FBIS-NES-2001-1016.

462. Barry Schweid, "Bush: Israel Hindering Anti-Terror Coalition.” AP, Jerusalem Post, Oct. 23, 2001. http://www.jpost.com/Editions/2001/10/23/LatestNews/LatestNews.36811.html (accessed Oct. 29, 2001).

463. Janine Zacharia and Lamia Lahoud, "Bush: Our War Comes First.” Jerusalem Post, Oct. 24, 2001. http://www.jpost.com/Editions/2001/10/24/News/News.36820.html (accessed Oct. 28, 2001). 
down on the Palestinians, and then to pressure us to withdraw." On a more positive note, an official present at the meeting reported that at his meeting with Peres, Bush had kind words for Israel's Ambassador to the U.S., David Ivry, saying, "Your ambassador is a very fine man. He's one of Israel's best. He gave us all an example of preemptive action." (The preemptive action to which Bush referred was Ivry's command of the 1981 bombing of the Iraqi nuclear facility at Osirak.) "The president was quite warm about it," the official added. ${ }^{464}$

Sharon's visit to Washington and London, scheduled for Nov. 7-13, was postponed due to Israel's volatile security situation and the impending deployment from the Palestinian Area A, which Sharon wanted to be on hand to personally supervise. Privately, administration officials suggested that Sharon did not want to withdraw, nor did he want to face a reprimand from Bush. ${ }^{465}$

During talks with Condoleezza Rice in Washington DC in early November, Transport Minister Ephraim Sneh complained to reporters that the U.S. seemed to be ignoring Iran’s terrorism record in the coalition-building process, and that Iran should be disqualified from any role in the U.S. alliance against terror. ${ }^{466}$ "Iran stands in first place as a sponsor of terrorism," Sneh said. "If someone forgets that, we are willing to remind

464. Zacharia and Lahoud, Jerusalem Post, Oct. 24. Online.

465. Herb Keinon, “Sharon Cancels his Trip to the US.” Jerusalem Post, Nov. 4, 2001. http://www.jpost.com/Editions/2001/11/04/News/News.37450.html (accessed Nov. 5, 2001).

466. Jonathan Wright, Reuters, "Israelis Say Iran Not Eligible to Join Alliance,” Jerusalem Post, Nov. 7, 2001. 
them.” Iran was providing arms via Syria to Hizbullah, which was branded a terrorist organization by the State Dept. and had attacked Israel from southern Lebanon. Iran had deployed "thousands of missiles" in southern Lebanon, with a range of 40 to 45 miles, across Israel’s northern border. Sneh expressed his certainty that Russia was damaging Israel’s security by supporting Iran’s nuclear weapons program. "We believe they cannot be considered as countries that fight terrorism.” Sneh declared. Putin denied that Russia was providing dangerous weapons technology to Iran in a taped interview on ABC's news program $20 / 20 .^{467}$

The capture of the Karine A made January 3, 2002 “one of the prime minister's happiest days since winning the elections on 17 February,” according to one Israeli news commentator, since it "availed him military credit and justification for his diplomatic tactics, along with an important political bonus,” saving his government from a coalition crisis. Having exposed the violent face of the Palestinian Authority, "Sharon can now claim that the cease-fire with Yasir Arafat is worthless and that even the lull in the violence in the territories could turn out to be a ruse to assist the huge arms smuggling operation.” 468

467. Barry Schweid, AP, “Sneh: Russia helps Iran, the Biggest Terrorist Threat.” Jerusalem Post, Nov. 7, 2001. http://www.jpost.com/Editions/2001/11/07/LatestNews/LatestNews.37730.html (accessed Nov. 8, 2001).

468. Shalom Yerushalmi, “Sharon's Rescue Ship,” Maariv (Hayom Supplement), Jan. 7, 2002, WNC Doc. FBIS-NES-2002-0107. 
When the 4,000 ton cargo ship docked in Eilat the following day, its inventory included Katyusha rockets with various ranges, mortar shells, anti-tank missiles and mines, rifles and ammunition, as well as rubber boats and diving equipment, valued by Israeli intelligence sources at $\$ 15$ million The ship itself was estimated to be worth $\$ 400,000$. Expenses of this amount, these sources said, would most certainly have had to be personally approved by Yasser Arafat, as would contacts with Iran, which were a "sensitive" matter for the U.S. ${ }^{469}$ The intercepted arms included both tactical weapons for infantry use and strategic weapons for terrorist attacks, and were made in Russia, China, and North Korea. ${ }^{470}$ Israeli Defense Forces Chief of Staff Shaul Mofaz pointed out that many of arms on board the ship not only would have enhanced the threat to Israeli citizens, but were forbidden to the PA according to its agreements with Israel. The Foreign Ministry announced that the arms shipment proved that Arafat and the PA were not acting to prevent terror, and that Prime Minister Sharon had been justified in insisting on the dismantling of the terrorist infrastructure. ${ }^{471}$

PA Information Minister Yasser Abed Rabbo called the arms smuggling attempt a fabrication: "Of course the Israeli authorities chose the moment of [U.S. envoy Anthony] Zinni’s visit to Palestinian territory to announce the ship’s discovery, just as at this time, the Israeli occupation forces are continuing their escalation and their closure on

469. Ze'ev Schiff and Revital Levy-Stein, “IDF Seizes Massive Arms CargoBound for PA,” Haaretz, Sunday, Jan. 6, 2002.

470. Revital Levi-Stein, “Huge Arms Cargo Required Careful Handling.” Haaretz, Sunday Jan. 6, 2002.

471. Schiff and Levy-Stein, Haaretz, Jan. 6. 
the territories.” When asked about the Karine A by Zinni, Yasser Arafat said he had no information about it but would cooperate with an international inquiry. ${ }^{472}$

A chronology published in Haaretz reported that Israeli naval intelligence had discovered the ships' purchase by the Palestinian Authority a few months earlier and began monitoring its activities. When the ship, under a Tongan flag, reached the Iranian island of Kish, its weapons cargo was loaded, and it sailed for Yemen. Crew members claimed that the ship was to have loaded additional arms there, but did not. The ship sailed for the Red Sea, where it was to have continued through the Suez Canal, left its cargo off the coast of Gaza, and sailed to Bulgaria for repairs. ${ }^{473}$

Three weeks prior to its interception, Prime Minister Sharon had met with top military officers at his home, and approved “Operation Noah's Ark." The site of the interception-between Saudi Aabia and Sudan—was supposed to have avoided both political and military complications which would have occurred had it taken place off the Egyptian coast. Spy planes, fighter planes, and combat helicopters took off from Israel a few hours before the interception, which was personally supervised by IDF Chief of Staff Mofaz and the Commanders-in-Chief of the Israeli Navy and Air Force. The boarding party met no resistance from the ship's crew, only three of whom were awake at the time of the interception. ${ }^{474}$

472. Schiff and Levy-Stein, Haaretz, Jan. 6.

473. Haaretz Staff, “The Capture Took Months to Plan.” Haaretz, Jan. 6, 2002.

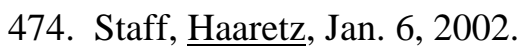


In the earliest reports about the Karine A interception, Iranian involvement appeared circumstantial and somewhat beside the point, other than reinforcing the perception of ties between terrorists of the PA and those sponsored by Iran. Army sources originally gave as evidence of Iranian involvement the loading of the ship on the Iranian island of Kish, and the loading of the ship, according to the Karine A crew, by Iranian speakers. Some of the weaponry and containers appeared to have Persian writing on them. ${ }^{475}$ An anonymous senior U.S. Bush administration official told the New York Times that the U.S. had no information that would confirm that the weapons were destined for the Palestinian Authority, nor any proof that it had originated in Iran, and suggested that they were intended for Hizbullah in Lebanon, not the Palestinians. But a statement issued by the U.S. State Dept. the same day criticized the smuggling of weapons into the region and accused Iran of providing arms, financing, training and refuge to Hizbullah, Hamas, and Islamic Jihad. ${ }^{476}$

A discussion of the strategic implications of the capture of the Karine A by military affairs correspondent Ze'ev Schiff in Haaretz listed as first among the strategic implications of the Karine A that "Israel will emphasize the incident in its contacts with U.S. officials, using it as an example of Iran's involvement in the export of arms to the PA. Despite Iranian attempts to conceal its activities in this regard, the capture of the ship is the latest in a series of proof of Iran's arms exports.” Next on the list was the

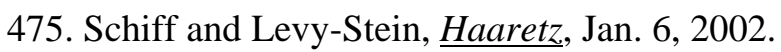

476. Nathan Guttman, "U.S. Thinks Arms Were Bound for Hezbollah, NY Times Says; Israel dismisses Report.” Haaretz, Jan. 6, 2002. 
indication that the PA planned to escalate violent attacks on Israel's civilian population, and finally, with regard to future negotiations with the PA, "It is now clear that a demand for a total cease-fire will not be enough for Israel." ${ }^{477}$

The Iranian connection received little attention from Palestinian skeptics, who accepted the official PA explanation that the Karin A was an Israeli propaganda trick designed to subvert Zinni’s visit. ${ }^{478}$ A few Israeli journalists expressed skepticism as well. Zvi Bar'el considered the most perplexing question about Iranian role in the Karine A affair to be why, if the arms shipment originated in Iran and official Iranian elements were behind the transfer, the ship would not have loaded its cargo and sailed directly from the Iranian port of Bandar Abbas to its destination, whether to the PA or Hizbullah. Bar'el suggested that the parties behind the transfer effort might have been "members of the Iranian military or intelligence services who had operated without the full backing of authorities in Iran," and pointed out that corrupt elements in the security services might have profited from turning a blind eye to a clandestine shipment of weapons if they took place outside normal ports. Bar'el also raised numerous other questions regarding the official version of the Karine A chronology. With respect to Iranian motives for arming the Palestinians, he noted that "Tehran is shying away from establishing formal links with Yasser Arafat and the Palestinian leadership. In the wake of September 11, Iran is also keen to stress its efforts in the war against terror and has undertaken a 'positive

477. Ze'ev Schiff. “Analysis: A Ship Laden with Strategic Impact.” Haaretz, Jan. 6, 2002.

478. Danny Rubinstein, "Palestinians Label Ship Story 'Israeli Propaganda Trick.”” Haaretz, Jan. 6, 2002. 
neutrality' in Afghanistan, allowing U.S. humanitarian aid flights to pass through its air space."

Despite such questions being raised, the strategic significance of the Iranian role in the Karine A operation rapidly moved to the forefront of Israeli government discussions. Prime Minister Ariel Sharon told a political meeting that "Iran is entering our region, adding that this situation completely changes our strategic situation.” Sharon told a reporter of the major Hebrew daily Maariv that Iran is operating "three arms” against Israel—the Hizballah rockets in Lebanon; the PA, the intended recipients of the Karine A weapons; and Israeli Arabs, among whom Israel had discovered Iran making "inroads." Sharon refused to provide details about the Israeli Arab-Iranian connection, but declared that "Iran is manipulating these three arms as marionettes.”480 In Washington the following week, IDF Chief of staff Mofaz met with Condoleezza Rice, Anthony Zinni, Deputy Secretary of State Richard Armitage, and Deputy Secretary of Defense Paul Wolfowitz. Mofaz's version of the tripartite Iranian threat consisted of the northern border threat from south Lebanon in cooperation with Hizbullah, Iran's "new 'strategic alliance’ with the Palestinians”; and “a long-range, existential threat posed by new missiles like the Shahab-3, which can reach Israel when launched from Iran.” Mofaz, who asked that Zinni not be sent back to Israel in light of Palestinians being "steeped in

479. Zvi Bar’el, “Analysis: A Perplexing Route.” Haaretz, Jan. 6, 2002.

480. Shalom Yerushalmi: "Sharon: Iran Is Entering the Region and Could Drag Us to War.” Maariv, Jan. 11, 2001. WNC Doc. FBIS-NES-2002-0111. 
terror," said upon his return that he believed "the Americans were listening to Israel 'very carefully’." 481

A sensationalistic feature story in Maariv on the Karine A investigation emphasized new details about Iranian involvement in the Israeli-Palestinian conflict. According to this account, said to be based upon information provided Karine A crew members "headed by Captain Umar Akkawi, who is familiar with all the details and is considered an information 'goldmine' in the investigation," it was Hizballah, not the PA, who bought the ship for $\$ 400,000$ cash, although high-level PA figures were involved in its selection. One of them, Fu'ad al-Shubayki, head of procurement in the Palestinian national security services, then left for Teheran, and with "senior officials in the Iranian security services, and with officials in the Ayatollah administration,” who told him the Iranians would give the 50 tons of weapons, as well as the ship, to the Palestinians for free, because they wanted to assist their struggle against the Zionists. The Palestinians had only to pay the "insignificant cost" of the salary of the four crewmembers and the small salaries of nine foreigners and mostly Egyptian sailors. ${ }^{482}$

While the Palestinian interest in the weapons deal was clear, "the security establishment was professed to be appalled to learn the depth and the intimacy” of the Iranian connections, which, based upon the Karine A investigation was "far more dangerous than it was made out to be.” An unidentified senior official was quoted as

481. Janine Zacharia, "Mofaz: Iran to have Nonconventional Weapon in Two or Three Years.” Jerusalem Post, Jan. 20, 2002. http://www.jpost.com/Editions/2002/01/20/News/News.41948.html (accessed Jan. 23, 2002).

482. Yo'av Limor: "Senior Source: Ali Khamene'i Was Involved in Karine A Affair." Maariv, Jan. 18, 2002 WNC Doc. FBIS-NES-2002-0118. 
stating that "Israel has firm evidence that this is not a deal between low-ranking clerks, but a deal involving all the leaders: Arafat on the Palestinian side, Ali Khamene'i on the Iranian side, and Hasan Nasrallah in Lebanon. The mediator between the three was Imad Mughniyah, Hizballah's chief of terrorist attacks abroad.

During Defense Minister Ben-Eliezer's trip to the United States, where he was scheduled to meet with "all the senior officials in the administration and security establishment," he planned to address the issue of Iran's accelerated efforts to procure long-range missiles and nuclear weapons. These weapons not only were a threat to Israel, but to the entire world. "Such strategic power in the hands of the extreme Ayatollah regime in Teheran will indirectly threaten the Gulf countries as well and will give them full control over the world's oil resources,” Ben-Eliezer said. He added that Iran planned to develop missiles with a wider range than the Shihab-3 (1,300 kilometers), which could reach any target in Europe, and eventually the U.S. The Defense Minister, who was certain that Iran would have its first nuclear bomb within three years, suggested that this was the time to act.

Even intelligence experts who disagreed with Ben Eliezer about the timeline were reportedly in agreement concerning the general acceleration of the trend toward Iranian nuclear capability and its implications. An unnamed senior official claimed that Iran had recently been directing its efforts into the nuclear field, with Russian assistance, as well as toward producing a steady production line of Shahab missiles into operational missiles with the aid of North Korea and China (to whom the Israelis had been prepared to sell Phalcons until the U.S. intervened). The more the details that were exposed about Iranian involvement, the greater its scope was revealed. Current Israeli effort "is aimed 
at convincing these countries both to renounce Iran and to return it to the category of the 'baddies.' This is a not-so-simple diplomatic and security effort that to a large extent will determine not only the quality of life in the State of Israel, but also its mere existence.”483 An analysis in the Jerusalem Post by Miriam Shaviv noted that Ayatollah Khameini had denounced Arafat as a lackey of the U.S. back in November of 1998 when he signed the Wye memorandum, and that Arafat is regarded as a "Zionist" in Iran, where he is booed at anti-Zionist rallies and is generally regarded as a persona non grata. Israel's claim that Iran and Arafat had formed a strategic alliance therefore "indicated a serious about-turn, and for Israel, a potentially dangerous development.” Shaviv quoted Sharon’s foreign policy adviser Zalman Shoval, a former Israel ambassador to the U.S., who declared that "By cooperating with the Palestinian Authority, the Iranians have become an immediate threat." Most of Israel's evidence, although revealed to the Americans during the past week, remained confidential. ${ }^{484}$

Nevertheless, Shaviv included denials of the allegations by both Iranian Defense Minister Ali Shamkhani and Palestinian Authority Information Minister Yasser Abed Rabbo, who challenged Israel to produce proof of its allegation, and quoting Rabbo that the accusations of military cooperation were "absurd, designed to frighten the United States, Europe, and even some Arab countries.” Shaviv added that some highly respected

483. Limor, Maariv, Jan. 18, 2002.

484. Miriam Shaviv, “A Chill Wind from Teheran.” Jerusalem Post, Jan. 20, 2002. http://www.jpost.com/Editions/2002/01/20/Features/Features.41957.html (accessed Jan. 21, 2002). 
Israeli analysts cautioned against rejecting these denials out of hand, and considered the evidence backing up the allegations to be "shaky."

Gerald Steinberg, Director of the Program on Conflict Resolution and Negotiation at Bar-Ilan University, and an op-ed contributor to the Post, emphasized that such an alliance, if it existed, had to be viewed in the context of the ongoing power struggle between the Khatami-led reformists revolutionary Iranian die-hards; if the arms shipment did originate in Iran, might have been organized by one of Iran’s quasi-military organizations associated with hardline conservative elements, without the knowledge and consent of President Khatami. Reverting to sources that supported the Israeli government's official position, Chief of Staff Mofaz was quoted as recently telling the press that as far back as the previous April, “direct contacts began to be forged gradually between Yasser Arafat's close aides and the most senior levels in Teheran. A most dangerous axis began to be created, consisting of an attempt to infiltrate the region.”

Nevertheless, Steinberg was given the last word, warning that confrontation with Iran should be avoided. "The fact that Iran has denied involvement in the Karine A arms shipment, instead of bragging about it, is a sign they are not looking for a confrontation.” He noted that "we share a lot of interests and dangers, like Iraq," and recommended evaluating the changes taking place in Iran until a change in regime has taken place. ${ }^{485}$

On January 29, 2002, U.S. President George W. Bush, in his State of the Union address, declared Iran to be part of an "axis of evil,” along Iraq and North Korea. "By seeking weapons of mass destruction, these regimes pose a grave and growing danger.

485. Shaviv, Jerusalem Post, Jan. 20, 2002. 
They could provide these arms to terrorists, giving them the means to match their hatred. They could attack our allies or attempt to blackmail the United States. In any of these cases, the price of indifference would be catastrophic.” Bush specifically asserted that Iran "aggressively pursues these weapons and exports terror, while an unelected few repress the Iranian people's hope for freedom.”486

The response from Tehran was swift. During a cabinet meeting on January 30, President Khatami condemned Bush's remarks as "intervening, warmongering...and worse than all, truly insulting towards the Iranian nation.” Khatami stated that "Iran is both a victim of terrorism and a victim of chemical weapons, which were generously donated to our enemies by those who were after uprooting the Islamic Revolution.” It was unfortunate that after the September 11 terrorist attacks on the U.S., when world public opinion was mobilized to counter international terrorism, "that great and important opportunity was misused,” thereby doing injustice to all mankind. ${ }^{487}$

The next day, Supreme Leader Ayatollah Khamenei said that the president's words seemed to be coming from "a person thirsty for human blood" He declared that "The Islamic Republic of Iran is proud of having come under the rage and wrath of the greatest Satans.” Khamenei took particular exception to Bush’s reference to the Iranian government be composed of "unelected leaders." "Contrary to the unlively elections held

486. White House Release, State of the Union Address, Jan. 29, 2002.

http://www.whitehouse.gov/news/releases/2002/01/20020129-11.html (accessed Jan. 31, 2002).

487. “President Khatami rejects Bush's statements on Iran,” IRNA, Jan. 30, 2002. http://www.irna.com/en/tnews/020131232938.etn00.shtml (accessed Jan. 31, 2001). 
in the West, officials of the Islamic Republic of Iran have been elected with majority vote and public affection." Khamenei decried American hypocrisy in supporting "the atrocious Zionist regime and the Israeli crimes against the innocent Palestinians,” and said that Bush’s “outrageous remarks" confirmed that "Washington looks at international principles and conventions as a tool to meet its ends and interests." 488

\section{Summary}

During the period under examination, Israel and Iran both used the "War on Terror" to attempt to secure their own political interests. How well they succeeded is beyond the scope of this study, which focuses on the dominant themes and metaphors related to "master commemorative narrative" in Israeli and Iranian political discourse and public diplomacy. Israel raised the Iranian nuclear issue each time U.S. pressure was brought to bear for withdrawal from the territories. The Israeli metaphors about and analogies to the Holocaust--preventing a Holocaust that would result from Iranian nuclear acquisition, comparing the U.S. demand for Israeli territorial and policy compromises to the German invasion of Czechoslovakia in 1939, and implying that danger posed by Iran was an imminent threat to Israel's existence.

Israel's major concern after 9/11 was the incorporation of Iran into the anti-terror coalition might require the sacrifice U.S. friendship with Israel, undermining Israel's exceptional status as the only ally upon which the U.S. and the West can depend. Loneliness and fear of betrayal—of being stabbed in the back"—as the U.S. sought allies

488. “Ayatollah Khamenei says US itself is `the greatest evil',” IRNA, Jan. 31, 2002. http://www.irna.com/en/hphoto/020130000000.ehp.shtml (accessed Feb. 3, 2002). 
in the Muslim world that might be a harbinger of 1938 Europe, were evident in Israel's public diplomacy in the post 9/11 period, especially in its adamant refusal to concede to Iran any positive place in the anti-terror coalition.

Iranians, for their part, made clear their fear of invasion and injustice, not just into Iran but into the region, and lobbied for action against Afghanistan under U.N. auspices. They focused on securing a definition terrorism that would allow for their support of the Palestinians and Hizbullah, and argued against the double standards with regard to the nuclear issue as well as in defining terrorism. Iran attempted to deprive Israel of its historical comfort zone and its role as sacrificial victim, casting it as the aggressor, the plotter, and a deceiver that incarnates the root cause of the terrorism experienced by the U.S. The accusation that Israelis had deceptively masterminded the 9/11 attacks, or "had a hand in them," illustrates the suspicion of Iranians toward threats of foreign interference, and the propensity toward conspiracy theories in situations of uncertainty and vulnerability..

The initial phase of US reaction to 9/11, and the Western world's positive view of Iranian responses, particularly the possibility of it being a partner isolating the plague of terrorism from the rest of the Muslim world, opened a window for possible alternative narratives in Iran. The Karine A incident, whether or not it was authentic, served as the basis of the "Axis of Evil" speech, undermined potential alternative narratives, and reinforced Iran's own self- image as both a victim and the true champion of justice. 


\section{CHAPTER V}

\section{CONCLUSIONS: FROM NARRATIVE TO POLICY}

Karen Armstrong explains that in the premodern world, there were two ways of thinking, speaking, and acquiring knowledge, mythos and logos, with primacy accorded to myth. By looking back to the origins of life and the foundations of culture, myth gave meaning to the lives of the people within a society. In the mythic view of history, people were far less concerned with what had actually happened than with the meaning of events. "Historical incidents were not seen as unique occurrences, set in a far-off time, but were thought to be external manifestations of constant, timeless realities.” Mythic events were historicized through narratives that brought out their eternal dimension, and, being a reflection of eternal truths, history would repeat itself. ${ }^{489}$

Logos, "the rational, pragmatic, and scientific thought that enabled men and women to function well in the world" could give order and direction to daily life, but could not give it ultimate value, assuage pain and sorrow, or make sense of tragedy. Armstrong contends out that pre-moderns understood very well that mythos and logos had separate jobs to do. Truths of myth were not intended to be empirically demonstrable. Armstrong also credits successful pre-modern leaders with the realization that "You were not supposed to make mythos the basis of a pragmatic policy. If you did so, the results could be disastrous...” 490

489. Karen Armstrong, The Battle for God: A History of Fundamentalism (New York: Random House, 2000), xv.

490. Armstrong, xvi-xvii. 
In Israel and Iran, however, myth often does serve as the basis for policy, and even more frequently as a justification for policy. This concluding chapter offers a summary of three themes where myth is incorporated into "master commemorative narrative" in some surprising ways, illustrating the flexibility and fungibility of myths in terms of various interpretations regarding these themes that they were able to absorb. They are: 1) the few against the many; 2) messianism and 3) the Palestinian issue.

1. "The few against the many." The Karbala paradigm represents resistance in Iran's revolutionary rhetoric. During the Islamic revolution, the Karbala paradigm was interpreted as a battle of the faithful—Khomeini in the role of Imam Husayn and his small party of followers—against the Shah, representing Yazid, and his mighty army. ${ }^{491}$ In the Iraq war, the entire Iranian people was cast as Imam Husayn fighting for iman (faith) against kufr (unbelief). The people were assured by their leaders that God would be fighting on their side. Iman not only served as a means of mass mobilization, but as a justification for a war for the true Islam, represented by the Iranian people. Numerically, Iran's population far outnumbered that of Iraq. By recasting "the few" as the true Muslims, and the many as those who did not fight along with God in the spirit of Karbala, the "few against the many" was able to serve as a mobilizing force to keep the war going, after Iran had successfully repelled the Iraqi attack, and was in a superior position vis-à-vis the Iraqi forces. ${ }^{492}$

491. Momen, 288.

492. Gieling, 76-79. 
In Israel, the theme of the "few against the many" is a well-known theme from the Book of Maccabees, easily recognizable by Jews who were a small minority against "the nations" wherever they were. The phrase was a dominant motif in Israeli self-perception during the 1920s and 1930s. During Israel's War of Independence, however, the phrase was "too dangerously close to reality" to serve as an effective mobilizing theme. Instead, the battle became for a new identity. The Zionist revolution was a revolt against the fate of the Jew in the gentile world. ${ }^{493}$

"All other revolts, both past and future, were uprisings against a system, against a political, social or economic structure,” Ben-Gurion declared. “Our revolution is directed not only against a system, but against destiny, against the unique destiny of a unique people." $^{494}$ Israeli identity is conceived of as the antithesis of the diaspora Jewish identity: Israelis return to their land as conquerors. Ironically, the old Jewish identity was then projected onto Arabs. Arab refugees, during and after the war, were even described disparagingly as "wandering Jews." 495 Perhaps not surprisingly, most of the options Israelis have envisioned for Arab have been based on those endured by the Jews in Europe—-segregation in their own communities, autonomy and separation.

2. Messianism. Iranian leaders deliberately discouraged messianism during the Iraq war, and played down expectations that the hardships of the Iran-Iraq war would bring about the long-awaited return of the mahdi. The goals of the return of the mahdi

493. Gertz, 29.

494. David Ben-Gurion, “The Imperatives of the Jewish Revolution (1944).” The Zionist Idea, ed. Arthur Hertzberg (New York, Temple Books/Atheneum, 1959), 607.

495 Gertz, 34. 
were the same as those of the Islamic republic itself-the establishment of the ideal state - and Iran's leaders did not want to arouse millenarian anticipation that could prove destabilizing during and after the war. ${ }^{496}$

The Six Day War, on the other hand, was viewed as replete with messianic implications. "This war stopped the sun in its orbit," wrote Aharon Meged. "It seemed that all the powers above were taking part in it. If war was being waged in the skies, then it was not the air force alone that was fighting; and if all the armies of the land, then it was not the Israeli army alone...the entire space was filled with biblical verses, biblical prophesies, psalms, kabbalistic homilies, mystic symbols." ${ }^{497}$ The messiah who came, however, was none other than the new Jew: "The messiah arrived in Jerusalem—tired, grey, and riding on the back of a tank. He led a column of armoured vehicles forward as Arab mortars showered shells upon them...The messiah was wearing an army uniform this time. An IDF soldier, a Jewish warrior... 498

After the Six Day War, the implications of living in the messianic era began to manifest themselves. Rabbis declared that with the recapture of the Temple Mount, the end of days was near. The Gush Emunim movement galvanized to reclaim the territories captured during the war, and to create "facts on the ground" to prevent its return. Political leaders were helpless against the onslaught of messianic fervor, either out of

496 Gieling, 126.

497 Gertz, 98.

498. Gertz, 34. 
sympathy with it or uncertainty as to how to cope with the first great surge of populism of a "normal” nation.

3. The Palestinians. Ayatollah Khomeini's earliest fulminations against Israel on the issue of Palestine, dating back to the early 1960s, focus on reclaiming the territory of Palestine and the plight of Arab refugees. He castigated the heads of the Arab states, who banded together in to contest an Israeli attempt to divert the course of the Jordan River, for choosing to fight over a river instead of all of Palestine. In the meantime, "The defenseless Arabs were expelled and now about a million or more of them are hungry and miserable in the desert." ${ }^{499}$

The association of Iran with Palestinian cause is generally perceived in the West in terms of Iran supporting and directing the activities of terrorist movements in order to control them. It was the PLO, however, that trained some of the revolutionaries who brought about the 1979 Islamic revolution in Iran. Khomeini was brought to power and supported by a number of Palestinian-trained Iranian revolutionaries, and in return, the PLO demanded political and material support, including arms, funding and human resources. ${ }^{500}$ In the early 1970s, young Iranians were admitted to Palestine Liberation Organization (PLO) camps Syria, Iraq, Lebanon and Libya. Arafat's Fatah backed Khomeini as well as the Iranian Marxist Mujahidin al-Khalk, while the Marxist-atheistic Popular Front for the Liberation of Palestine (PFLP), led by George Habash supported the Marxist-Leninist Fedayi'in Khalk movement, the Democratic Front for the

499. The Imam's Message of the $21^{\text {st }}$ of Favardin, 1343 (April 10, 1964), The Imam versus Zionism., 20.

500. Souresrafil, 46. 
Liberation of Palestinian (DFLP) allied itself with Iranian leftists who were loyal to Moscow. Yet another group, the Palestine Liberation Front (PLF) directed its energies toward the ethnic Arabs of Khuzistan who were later encouraged by the PLF and Iraq to rebel against Khomeini. ${ }^{501}$

Immediately after the revolution, Arafat invited himself to Teheran to personally congratulate Khomeini on his victory, declaring he needed no invitation. Iran's new and none-too-secure regime was not pleased by the reports of the PLO and PFLP provoking Khuzistan's Arab minority, nor by Palestinian support for groups hostile to the Islamic regime. Much to Arafat's annoyance, Khomeni insisted that Iran, in light of its own pressing needs, was unable to help the Palestinians very much in a material way. In the escalating conflict between Iran and Iraq, the Palestinians were seen as backing Iraq. By the end of 1980, "the real honeymoon" between Khomeini and Arafat was over. ${ }^{502}$

Nevertheless, while Khomeini proclaimed August 17 as Quds (Jerusalem) Day, and called for worldwide demonstrations by Muslims demanding Palestinian rights, he had little use for Palestinian leaders. The colder his relationship with actual Palestians leaders, the more fervent and strident the Quds Day speeches became, targeting U.S. imperialism and calling for Israel's elimination. Ironically, during the Iran-Iraq war, Israel sold arms and spare parts to Iran's Islamic regime in seeming defiance of stated U.S. policy, as well as of Israel's own "master commemorative narrative," while arguing

501. S. Segev, 116-177.

502. Souresrafil, 48-50. 
that it was working to facilitate regime change in Iran. Regime change in Iran remained Israel's defense of its role in the Iran-Contra affair.

The biblical command to dwell in the Land and extirpate its prior inhabitants legitimates and reinforces the agreement among nearly all Israelis, from across the political spectrum that, in order for Israel to survive as both a state with preponderant Jewish population, and a democracy predicated on majority rule, Arabs must remain a minority, and the fewer of them within Israel's borders, the better. The debate is: should this be achieved by carving out some of the territory conquered by Israel in the Six Day War and giving it to the Palestinian Arabs, so that there is no need for them to be either full or second-class citizens of Israel? Many Israelis contend that there are many Arab states but only one Jewish state, and Palestinian Arabs should therefore be encouraged, persuaded, even forced, if necessary, to relocate outside the Land promised to the Jews. The peace process, even for liberal Israelis, is a matter of separation, not of co-existence.

In each of these issue areas, myth works in surprising ways. "Master commemorative narrative provides an entrée for assessing the use of myth in a broader context of meaning to a society. On their own, individual images can be misleading, even deceptive, because of their ambiguity and their power to be used in so many various ways.

In Jewish history, Cyrus credited by the Bible for ending the exile of the Jews of Babylon and allowing them to return to Judea. The majority of Jews, then and now, chose not to go. Cyrus is a reminder that whenever Jews have been offered the opportunity to return to their historic homeland, most have chosen not to do so. The figure of Cyrus challenges the Zionist "master commemorative narrative" because it is 
an unwelcome memory of a rupture in the continuity of Judean habitation of the Land of Israel more than six centuries prior to the two thousand year exile imposed upon the Jews by Rome in 70 CE. Furthermore, since the Second Temple period, more Jews have lived outside Palestine than in it. Finally, Cyrus is a reminder that much of Judaism developed in a Persian cultural milieu, and Jews shared many rituals and values with their neighbors. For these reasons, Cyrus, although a hero, is an ambivalent and ambiguous figure in Jewish history, for and about whom no commemorative rituals exist.

For Iranians, Cyrus is a reminder that they were once a mighty empire, and that there is no reason that they cannot be one again. For those looking for models of tolerance, Cyrus is invoked as a benevolent conqueror whose treatment of his conquests was respectful of their traditions. Initially, the Islamic Revolutionary regime that gained power in 1979 associated Cyrus with the most negative aspects of the Shah's rule, deriding him as an imperialist, a Zionist, and even a Jew. Eventually he came to be seen, however, as part of a long history of Iranian courage and endurance that predated but also includes its Islamic heritage, and supportive of a benevolently expansive foreign policy.

The lesson of Cyrus is that, he is a shared historical meeting point of Israeli and Iranian. At this time it appearsto be in no one's interest to bring him to life again. In the future, however, if and when a myth of reconciliation is needed, he will be there, ready to be adapted into a new myth commemoration.

In the meantime, the dramatic changes in mythos engendered by the election of Menachem Begin as Israel's Prime Minister in 1977, and the establishment of the Islamic Republic of Iran in 1979, seem frozen in time. The political discourses of both Israel and Iran metamorphosed from the dream of recapturing the ancient glory of two 
millennia ago through rapid modernization and westernization to the articulation of deepseated grievances toward most of the rest of the world, expressed in the "people that dwells alone" and "every day is Ashura" paradigms. Religiously mandated exceptionalism shaped and drove this sense of victimization as well as providing the images and metaphors for its expression.

The European Holocaust, through the association of Hitler with Amalek and Haman, has become an extension of the biblical narrative. Israel's founding generation of Labor leaders considered the Holocaust and the triumph of Amalek to be an embarrassment for the Jewish people, and yet they willingly spoke of it abroad to arouse gentile guilt. Begin's foreign policy rhetoric transformed the Jewish state from a haven where the oppressed and victimized Jews of the world could be empowered and "normalized" to the quintessential symbol of the Jewish people as a victim of "the nations.” The right wing slogan "Never Again!” justified the use of pre-emptive violence as a religious obligation, in order to prevent another Holocaust, as in the case of the Israeli attack on Iraq's nuclear reactor at Osirak. Israelis frequently speak of doing attacking nuclear targets in Iran, based upon the biblical right to act preemptively to kill a would-be murderer, on the basis of the Bible and commentaries. in order save the lives of Jews, hoping it would force regime change. With a Karbala paradigm at the heart of its national self-perception, it is hardly surprising that threats have exactly the opposite effect than intended in changing state behavior.

The objective of this research has been to explain the religious and cultural dimensions of the foreign policies of Israel and Iran. Israel and Iran share an underlying sense of victimization and isolation that animates their domestic and foreign policy 
discourse, but also a vision of recapturing past glory in the present and gaining redemption in the future. The past is invoked and interpreted as a relevant model for the present through invocations of the paradigmatic images of Auschwitz and Ashura.

These contradictory narratives contextualize Israeli and Iranian foreign policy discourse. They are very much a part of the tensions between Israel and Iran. The Bible gives Israel a "comparative advantage” in marketing itself in the realm of public opinion in the U.S., presently the most powerful nation in the world. ${ }^{503}$ Former U.S. President Jimmy Carter recounts, "For me there is no way to approach or enter Israel without thinking first about the Bible and the history of the land and its people. The names and images have long been an integral part of my life as a Christian...It is rare indeed to find the distant past so intertwined with the immediate present, not just for historians and theologians in their classrooms and studies, but for statesmen in the halls of government and military commanders in the field of battle. ${ }^{504}$

Since the end of the Six Day War, Christian dispensationalists, not unlike those of Lord Shaftesbury's era, have become increasingly vocal and politically active in the

503. A few examples: Congressman J.C. Watts Jr. (Republican, House of Representatives, Oklahoma, 4th Congressional District 1994-2002), addressing an American Israel Public Affairs Committee (AIPAC) policy conference, told his audience of two thousand pro-Israel activists that he had first learned about Israel as a three year old child, when his father read him from the Bible to him. Mark Souder (Republican, House of Representatives, Indiana, 3rd Congressional District 1995- ), participated in the first visit to Israel organized by AIPAC exclusively for newly elected evangelical Christians after their election to Congressman in 1994. Souder recounted that the evangelical delegation's Israeli tour guide had told them, "You're our favorite group, because for you the history of Israel is the Bible, then silence, and then 1948 on." Interview with Lucky Severson, "Religion and Ethics News Weekly," April 23, 2004, episode 734. http://www.pbs.org/wnet/religionandethics/week734/interview1.html (accessed June 15, 2006).

504. Jimmy Carter, The Blood of Abraham (Boston: Houghton Mifflin, 1985), 1. 
Israeli-Iranian dynamic. They have used their influence to make common cause with pro-Israel groups such as AIPAC, and have even created their own Christians United for Israel (CUFI) that shows its support for Israel by unequivocal opposition to any peace process, no less vehement than Iranian opposition to the same process in the name of the Palestinians. Dispensationalists have become, in Timothy Weber's words, Israel's “new best friends" as well as "its most fierce and unwavering supporters, at the same time that they have tried to converts as many Jews as possible to the Christian faith. One should not expect this pattern of behavior to change any time soon., ${ }^{505}$

The myths that make up the Hebrew world view are perhaps unexceptional by the standards of small ethnic communities and religious sects," Raymond Cohen observes.

What is extraordinary about them is not only that they compose a secularized version of Judaism's historical self-consciousness itself but also that, with some variation and rationalization here and there, they have undergirded the ideology of a revolutionary political movement and molded the day-to-day discourse of a government in power in the midst of the twentieth century. ${ }^{506}$

This discourse, however, has strong mythic components that offer dangers as well as opportunities. In this respect they also share much with Iran.

What is also extraordinary is the Zionist movement's remarkable success in gaining acceptance of the modern State of Israel's identity with an idealized ancient polity depicted in the Bible, not only within Israel's domestic political discourse but in its foreign relations with primarily Christian countries, particularly the U.S. Within

505. Weber, 268.

506. R. Cohen, “Israel’s Starry-Eyed Foreign Policy.” 
academia the axiomatic acceptance of the identification of biblical and modern Israel is generally regarded as mainstream and normative.

In this study, I have argued that Iran and Israel have much in common in their "master commemorative narratives." These commonalities, rather than being shared, have been the focus of competition, as the national and religious myths of two peoples who base their identity not only on a vision of a glorious historical past but the possibility of a redemptive, utopian vision future. Ritual reenactments and "invented traditions" have served to sustain both visions.

The study of "master commemorative narratives" has the potential of opening up new ways of examining global conflict. The need for analysts to be aware of and understand a country's "master commemorative narrative" seem essential to effective diplomacy and devising feasible policy. Threatening Iran with attack for non-compliance with its IAEA, for example, would be recognized as counterproductive for anyone familiar with the Karbala paradigm. Challenging the historicity of the Holocaust is not simply a matter of re-investigating "facts,” as Iran's president declared, but is an attack on Israel's theology of suffering and redemption, not unlike the Karbala paradigm. Equally dangerous is the "routinization of catastrophe" in some Israeli discourse that insists that any demand for territorial compromise is tantamount to the roundup of Jews in 1939 for slaughter in European death camps.

It would follow that a crucial requirement for foreign service officers, diplomats, intelligence analysts and operatives, journalists, and academics dealing with a particular country would be to learn at least as much about its "master commemorative narrative" and the variant narratives it subsumes, as about its economy, demography, 
communication and transportation infrastructures and other considered useful by the CIA's World Factbook, Library of Congress Country Studies, and similar sources.Yet such information is rarely mentioned in discussions of foreign policy. Beyond narrow elite interests and manipulation of religious language to mobilize the masses, myths and “master commemorative narratives" can open up new insight into the motivations underlying political discourse and state behavior and understanding political discourse. 


\section{BIBLIOGRAPHY}

Abdi, Kaymar. “A History of Archaelogy in Iran.” American Journal of Archaeology 105, no.1 (January 2001): 51-76.

Abrahamian, Ervand. The Causes of the Constitutional Revolution in Iran. International Journal of Middle East Studies 10, no. 3 (August 1979): 381-414

Abisaab, Rula Jurdi. Converting Persia: Religion and Power in the Safavid Empire. London and New York: I.B. Tauris, 2004.

Abtahi, Hirad. "Reflection on the Ambiguous Universality of Human Rights: Cyrus the Great's Proclamation as a Challenge to the Athenian Democracy's Perceived Monopoly on Human Rights.” In The Dynamics of International Criminal Justice: Essays in Honour of Sir Richard May, edited by Hirad Abtahi and Gideon Boas, 1-38. Leiden: Martinus Nijhoff Publishers, 2006.

Adang, Camilla. “Medieval Muslim Polemics against Jewish Scriptures.” In Muslim Perceptions of Other Religions: A Historical Survey, edited by by Jacques Waardenburg, 143-159. New York and Oxford: Oxford University Press, 1999.

Adelkhah, Fariba. Being Modern in Iran. Translated by Jonathan Derrick. New York: Columbia University Press, 2000.

Aghaie, Kamran Scott. The Martyrs of Karbala: Shi'i Symbols and Rituals in Modern Iran Seattle: University of Washington Press, 2004.

Ahmadi, Nader and Fereshteh Ahmadi, Iranian Islam: The Concept of the Individual. New York: St. Martin’s Press, 1998.

Ajami, Fouad. The Vanished Imam: Musa al Sadr and the Shia of Lebanon. Ithaca: Cornell University Press, 1986.

Al-Biruni, Abu Raihan Muhammad ibn Ahmad. The Chronology of the Ancient Nations, an English version of the Athar-ul-Bakiya. Edited and translated by Edward Sachau. London: William Allen, 1879.

Arjomand, Said Amir. The Political Dimensions of Religion. Albany: State University of New York Press, 1993.

. The Shadow of God and the Hidden Imam: Religion, Political Order and Societal Change in Shi'ite Iran from the Beginning to 1890. Chicago: University of Chicago Press, 1984. 
Armstrong, Karen. The Battle for God: A History of Fundamentalism. New York: Random House, 2000.

Aronoff, Myron J. Civil Religion in Israel. RAIN (Royal Institute of Anthropology of Great Britain and Ireland) 44 June 1981: 2-6.

Myths, Symbols and Rituals of the Emerging State. In New Perspectives on Israeli History: The Early Years of the State, edited by Laurence J. Silberstein. New York: New York University Press, 1991: 175-192.

Ashtor, E. Prolegomena to the Medieval History of Oriental Jewry. The Jewish Quarterly Review, New Series 50, no. 1 July 1959: 55-68.

Avishai, Bernard. The Tragedy of Zionism: Revolution and Democracy in the Land of Israel. New York: Farrar Straus Giroux, 1985.

Bakhash, Shaul. The Reign of the Ayatollahs: Iran and the Islamic Revolution. New York: Basic Books, 1990.

Barnett, Michael N. "The Politics of Uniqueness: the Status of the Israeli Case.” In Israel in Comparative Perspective, Challenging the Conventional Wisdom, edited by Michael N. Barnett, 3-28. Albany: State University of New York Press, 1996.

Bascom, William. "The Forms of Folklore: Prose Narratives.” In Sacred Narrative: Readings in the Theory of Myth. Edited by Alan Dundes, 5-29. Berkeley: University. of California Press, 1984.

Ben-Gurion, David. Ben-Gurion Looks at the Bible. Middle Village, NY: Jonathan David, 1972.

Ben-Zvi, Itzhak. The Exiled and the Redeemed. Philadelphia: Jewish Publication Society, 1957.

Benham, M. Reza. Cultural Foundations of Iranian Politics. Salt Lake City: University of Utah, 1986.

Benjamin of Tudela. The Itinerary of Benjamin of Tudela: Travels in the Middle Ages. Introductions by Michael A. Singer, 1983; Marcus Nathan Adler, 1907; A. Asher, 1840. Malibu, CA: Joseph Simon/Pangloss Press, 1987.

Bennis, Phyllis and Khaled Mansour. Praise God and Pass the Ammunition!: The Changing Nature of Israel's US Backers” Middle East Report 208, US Foreign Policy in the Middle East: Critical Assessments. Autumn, 1998: 16-18+43.

Benvenisti, Meron. Conflicts and Contradictions. New York: Vintage Books, 1986. 
Berlin, Adele. The Book of Esther and Ancient Storytelling.” Journal of Biblical Literature 120, no. 1, Spring 2001: 3-14.

Berquist, Jon L. Judaism in Persia's Shadow: A Social and Historical Approach. Minneapolis: Fortress Press, 1995.

Biale, David. Eros and the Jews. (New York: Basic Books, 1992),

. Power and Powerlessness in Jewish History. New York: Schocken Books, 1987.

Bickerman, Elias. Four Strange Books of the Bible. New York: Schocken Books, 1967.

Bickerman, Elias J. The Historical Foundations of Postbiblical Judaism. In The Jews: Their History, Culture and Religion, edited by Louis Finkelstein, 70-114. Philadelphia: Jewish Publication Society of America, 1966: v.1, 3rd edition.

Bill, James A. The Eagle and the Lion: The Tragedy of American-Iranian Relations. New Haven and London: Yale University Press, 1988.

Bleek, Philipp C. 2002. "Nuclear Posture Review Leaks; Outlines Targets, Contingencies. Arms Control Today, April 2002. http://www.armscontrol.org/act/2002_04/nprapril02.asp

Boroujerdi, Mehraz. “The Paradoxes of Politics in Post-Revolutionary Iran.” In Iran at the Crossroads, edited by John L. Esposito and R. K. Ramazani. New York: Palgrave, 2001: 13-27.

Briant, Pierre. From Cyrus to Alexander: A History of the Persian Empire. Translated by Peter T. Daniels. Winona Lake, IN: Eisenbrauns, 2002.

Bonine, Michael E. and Nikki R. Keddie, eds. Modern Iran: The Dialectics of Continuity and Change. Albany: State University of New York Press, 1981.

Boyarin, Jonathan. “Reading Exodus Into History,” New Literary History 23, no. 3, Summer 1992, 523-554.

Brumberg, Daniel. Reinventing Khomeini: The Struggle for Reform in Iran. Chicago and London: University of Chicago Press, 2001.

Burrows, Millar. “Ancient Israel.” In The Idea of History in the Ancient Near East, edited by Robert Dentan, 101-130. New Haven: Yale University Press, 1955. 
Cameron, George G. "Ancient Persia.” In The Idea of History in the Ancient Near East. Edited by Robert Dentan. New Haven: Yale University Press, 1955: 79-97.

Carter, Jimmy. The Blood of Abraham. Boston: Houghton Mifflin, 1985.

Chomsky, William. Hebrew: The Eternal Language. Philadelphia: Jewish Publication Society, 1957.

Cohen, Haim. "Dangerous Halakha." In Free Judaism \& Religion in Israel, edited by Yaakov Malkin, 31-46. Farmington Hills, MI: Free Judaism, 1998.

Cohen, Raymond. “Israel’s Starry-Eyed Foreign Policy.” Middle East Quarterly, June 1994. http://www.meforum.org/article/221 (accessed January 13, 2007).

Cohn, Jonathan. "Irrational Exuberance: When Did Political Science Forget about Politics?" The New Republic, Oct. 25, 1999: 25-32.

Collier, Robert. "Nuclear Weapons Unholy, Islam Forbids Use, Clerics Say.” San Francisco Chronicle, Oct. 31, 2003.

Dabashi, Hamid. Iran: A People Interrupted. New York: The New Press, 2007.

The End of Islamic Ideology. Social Research (Summer 2000). http://www.findarticles.com/p/articles/mi_m2267/is_2_67/ai_63787340 (accessed June 3, 2005).

- Theology of Discontent: The Ideological Foundations of the Islamic Revolution in Iran. New York: New York University Press, 1993.

Dan, Joseph. Jewish Sovereignty as a Theological Problem. Azure 16 Winter 2004. http://www.azure.org.il/magazine/magazine.asp?id=167

Dandamaev, Muhamad A. and Vladimir G. Lukonin. The Culture and Social Institutions of Ancient Iran. English edition by Philip L. Kohl with the assistance of D.J. Dadson. Cambridge: Cambridge University Press, 1989.

Davis, Dick, trans. Shahnameh: The Persian Book of Kings by Abolqasem Ferdowsi. Introduction by Dick Davis. New York: Penguin Books, 2006.

Dorraj, Manochehr. From Zarathustra to Khomeini: Populism and Dissent in Iran. Boulder: Lynne Rienner Publishers, 1990.

Dowty, Alan. "Israeli Foreign Policy and the Jewish Question.” MERIA 3, no.1, March 1999. http://meria.biu.ac.il/journal/1999/issue1/jv3n1a1.html. 
Ellis, Marc C. “Jewish Theology and the Palestinians.” Journal of Palestine Studies 19, no. 3 Spring 1990: 39-57.

Elon, Amos. The Israelis: Founders and Sons. New York: Holt, Rinehart and Winston, 1971.

Esman, Milton J. and Itamar Rabinovich, editors. Ethnicity, Pluralism and the State in the Middle East. Ithaca and London: Cornell University Press, 1988.

Esposito, John L. ed. The Iranian Revolution: Its Global Impact. Miami: Florida International University, 1990.

Evron, Boaz. Jewish State or Israeli Nation? Bloomington: University of Indiana Press, 1995.

Falk, Ze'ev. “A Peace of Compromise between Israel and the Arabs. In Pomegranates and Golden Bells: Studies in Biblical, Jewish, and Near Eastern Ritual, Law and Literature in Honor of Jacob Milgrom, edited by David P. Wright, David Noel Freedman and Avi Hurvitz. Winona Lake, IN: Eisenbrauns, 1995: 473-478.

Farhi, Farideh. “To Have or Not to Have? Iran’s Domestic Debate on Nuclear Options.” In Geoffrey Kemp et.al., Iran’s Nuclear Weapons Options: Issues and Analysis. Nixon Center Monograph, 2001.

Feldman, Louis H. “Remember Amalek!”: Vengeance, Zealotry and Group Destruction in the Bible According to Philo, Pseudo-Philo, and Josephus. Cincinnati: Hebrew Union College Press, 2004.

Feldman, Shai. 1997. Nuclear Weapons and Arms Control in the Middle East. Cambridge and London: MIT, 1997.

Ferdowsi, Abdolqasem. Shahnameh: The Persian Book of Kings. Translated by Dick Davis. Introduction by Dick Davis. New York: Penguin Books, 2006.

Fischel, Walter J. "The Jews of Central Asia (Khorasan) in Medieval Hebrew and Islamic Literature.” Historia Judaica 7 (1945): 29-49.

Fischer, Michael. Iran: From Religious Dispute to Revolution. Cambridge: Harvard University Press, 1980.

Foundation for Middle East Peace (FMEP). "The Uncertainties of Peace: Regional Implications of Israeli-Arab Rapprochement.” Special Report. Spring 2000. 
Frank, Daniel, "The Shoshanim of Tenth-Century Jerusalem: Karaite Exegesis, Prayer, and Communal Identity. In The Jews of Medieval Islam: Community, Society, and Identity. Proceedings of an International Conference held by the Institute of Jewish Studies, University College, London, 1992, edited by Daniel Frank, 199245. Leiden: E.J. Brill, 1995:

Friedlander, Israel. Shi 'itic Influences in Jewish Sectarianism, In Essential Papers on Messianic Movements and Personalities in Jewish History, edited by Mark Saperstein. New York: New York University Press, 1992: 113-161.

Frye, Richard. The Heritage of Persia. New York and Toronto: New American Library, 1963.

Fuller, Graham E. The "Center of the Universe": The Geopolitics of Iran. Boulder: Westview Press, 1999.

Funkenstein, Amos. Perceptions of Jewish History. Berkeley: University of California Press, 1993.

Gaster, Theodor Herzl. Purim and Hanukkah in Custom and Tradition. New York: Henry Schuman, 1950.

Gera, Deborah Levine. Xenophon's Cyropaedia: Syle, Genre and Literary Technique. New York: Oxford Univ. Press, 1993.

Gertz, Nurith. Myths in Israeli Culture: Captives of a Dream. London and Portland, OR: Vallentine Mitchell, 2000.

Gheissari, Ali and Vali Nasr. Democracy in Iran: History and the Quest for Liberty. New York: Oxford University Press, 2006.

Gieling, Saskia. Religion and War in Revolutionary Iran. New York: I.B. Taurus, 1999.

Gillman, Sander and Steven T. Katz, eds. Anti-Semitism in Times of Crisis. New York: New York University Press, 1991.

Glazer, Nathan. Disaggregating Culture. In Culture Matters: How Values Shape Human Progress, eds. Lawrence E. Harrison and Samuel P. Huntington, 219-230. New York: Basic Books, 2000.

Gordon, Cyrus H. "The Substratum of Taqiyya in Iran.” Journal of the American Oriental Society 97, no. 2, Apr. - Jun., 1977: 192.

Gorenberg, Gershom, The Accidental Empire: Israel and the Birth of the Settlements, 1967-1977. New York: Henry Holt, 2006. 
Graf, David F. "Medism: the Origins and Significance of the Term.” Journal of Hellenic Studies 104, 1984: 15-30.

Grant, Michael. The Ancient Historians. New York: Barnes and Noble, 1970.

Green, David. Shaping Political Consciousness. Ithaca and London: Cornell, 1987.

Greenberg, Moshe. "On the Political Use of the Bible in Modern Israel: An Engaged Critique.” In Pomegranates and Golden Bells: Studies in Biblical, Jewish, and Near Eastern Ritual, Law and Literature in Honor of Jacob Milgrom, eds. David P. Wright, David Noel Freedman and Avi Hurvitz. Winona Lake, IN: Eisenbrauns, 1995: 461-471.

Haddad, H.S. “The Biblical Bases of Zionist Colonialism.” Journal of Palestine Studies 3, no. 4 Summer 1974, 97-113.

Hall, Edith. Inventing the Barbarian: Greek Self-Definition Through Tragedy. Oxford: Clarendon Press, 1989.

Halpern, Ben and Reinharz, Jehuda. "Nationalism and Jewish Socialism: The Early Years.” Modern Judaism 8, no. 3 October 1988: 217-248.

Hazleton, Leslie. Israeli Women: The Reality Behind the Myths. New York: Simon and Schuster, 1977.

Haynes, Jeff. Religion in Global Politics. London and New York: Longman, 1998.

Hazony, Yoram. “Did Herzl Want a ‘Jewish’ State?” Azure 9 (Spring 2000): 39-40.

Heard, R Christopher. Review (untitled). Review of James W. Watts, ed., Persia and Torah: The Theory of Imperial Authorization of the Pentateuch . Review of Biblical Literature Journal of Biblical Literature 122, no. 3. Autumn 2003: 555558.

Hedges, Michael. 2004. "Stopping Nuclear Proliferation More than a Subject for Debate.” Houston Chronicle Washington Bureau, Oct. 1, 2004, http://www.chron.com/cs/CDA/ssistory.mpl/politics/2825891.

Helmer, Christine and Christof Landmesser, eds. One Scripture or Many? Canon from Biblical, Theological and Philosophical Perspectives. Oxford: Oxford University Press, 2004. 
Herodotus, The Persian Wars. Translated by George Rawlinson. Introduction by Francis R.B. Godolphin. New York: Modern Library, 1942.

Hersh, Seymour M. The Samson Option: Israel's Nuclear Arsenal and American Foreign Policy. New York: Random House, 1991.

Hertzberg, Arthur and Leon A. Feldman. History and Jewish Historians: Essays and Addresses, edited by Salo W. Baron. Philadelphia: Jewish Publication Society, 1964.

Hirsch, Steven W. "Cyrus' Parable of the Fish: Sea Power in the Early Relations of Greece and Persia.” The Classical Journal 81, no. 3 February-March 1986: 222229.

Hobsbawm, E.J. Nations and Nationalism Since 1780: Programme, Myth, Reality, Second Edition. Cambridge: Cambridge University Press, 1992: 54.

Hobsbawm, Eric and Terence Ranger, eds. The Invention of Tradition. Cambridge: Cambridge University Press, 1983.

Hoodbhoy, Pervez. "Hardtalk: Global nuclear arms control is dead...Bush shot and killed it” Daily Times (Pakistan), May 30, 2002. http://www.dailytimes.com.pk/default.asp?page=story_30-5-2002_pg3_6 Scientists, June, 1993.

Hooglund, Eric. "Iranian Views of the Arab-Israeli Conflict." Journal of Palestine Studies 25, no. 1 Autumn, 1995: 86-95.

Hooglund, Eric. "Reagan's Iran: Factions behind US Policy in the Gulf." Middle East Report, no. 151, The Great Powers and the Middle East. March-April 1988: 2831.

Horowitz, Elliott. Reckless Rites: Purim and the Legacy of Jewish Violence. Princeton: Princeton University Press, 2006.

Inglehart, Ronald. Human Beliefs and Values : A Cross-cultural Sourcebook Based On the 1999-2002 Values Surveys. México Siglo XXI, 2004 (eBook).

Jafri, S. Husain M. Origins and Early Development of Shi'a Islam. London: Longman, 1979.

Kalmin, Richard. Jewish Babylonia between Persia and Roman Palestine. New York: Oxford University Press, 2006. 
Kammen, Michael. Mystic Cords of Memory: The Transformation of Tradition in American Culture. New York: Vintage Books, 1993.

Keddie, Nikki R. Modern Iran: Roots and Results of Revolution. New Haven: Yale University Press, 2003.

Kent, Roland G. “The Oldest Old Persian Inscriptions.” Journal of the American Oriental Society 66, no. 3 July- September, 1946: 206-212.

Khomeini, Ruholla. Islam and Revolution: Writings and Declarations. Translated and annotated by Hamid Algar. London: KPI, 1981.

- Imam Khomeini’s Last Will and Testament. Washington: Embassy of the Democratic and Popular Republic of Algeria, Interests Section of the Islamic Republic of Iran, 1989.

Korn, Eugene. “Moralization in Jewish Law: Genocide, Divine Commands, and Rabbinic Reasoning,” Edah Journal 5, no. 2, Sivan 2006. http://www.edah.org/backend/JournalArticle/KORN_5_2.pdf, (accessed Feb. 3, 2007)

Kurzman, Charles. The Unthinkable Revolution in Iran. Cambridge, MA: Harvard University Press, 2004.

Littman, Robert J. “The Religious Policy of Xerxes and the 'Book of Esther," The Jewish Quarterly Review, new series 65, no. 3 January 1975: 145-155.

Litwack, Robert S. Rogue States and US Foreign Policy: Containment After the Cold War. Washington D.C.: Woodrow Wilson Center, 2000.

Lustick, Ian S. For the Land and the Lord: Jewish Fundamentalism in Israel. New York: Council on Foreign Relations, 1988.

Maghraoui, Driss. "Moroccan Colonial Soldiers: Between Selective Memory and Collective Memory - Beyond Colonialism and Nationalism in North Africa," Arab Studies Quarterly 20, no.1 Spring 1998: 21-42.

Maloney, Suzanne "Identity and Change in Iran’s Foreign Policy.” In Identity and Foreign Policy in the Middle East, edited by Shibley Telhami and Michael Barnett, 88-115. Ithaca: Cornell University Press, 2002.

Menashri, David. Iran: A Decade of War and Revolution. New York and London: Holmes and Meier, 1990. 
ed. The Iranian Revolution and the Muslim World. Boulder et al:

Westview, 1990.

. "The Jews of Iran: Between the Shah and Khomeini.” In Anti-

Semitism in Times of Crisis, edited by Sander Gilman and Steven T. Katz. New

York and London: New York University Press: 353-371.

$215-232$

"Khomeni’s Policy toward Minorities.” In Esman and Rabinovitch,

Post-Revolutionary Politics in Iran: Religion, Society and Power.

London and Portland: Frank Cass, 2001.

Merkley, Paul C. The Politics of Christian Zionism 1891-1948. London and Portland: Frank Cass, 1998.

Messari, Nizar. "Identity and Foreign Policy: The Case of Islam in U.S. Foreign Policy." In Foreign Policy in a Constructed World, edited. by Vendulka Kubalkova, 227248. Armonk, NY: M.E. Sharpe, 2001.

Missiou, Anna. "Donlos ton basilews: The Politics of Translation.” The Classical Quarterly 43, New Series no. 2 (1993): 377-391.

Momen, Moojan. An Introduction to Shi'i Islam: The History and Doctrines of Twelver Shi'ism. New Haven: Yale University Press, 1985

Moreen, Vera Basch. In Queen Esther's Garden: An Anthology of Judea-Persian Literature. New Haven and London: Yale University Press, 2000.

Moreen, Vera Basch. Iranian Jewry's Hour of Peril and Heroism : A Study of Babai ibn Lutf's Chronicle (1617-1662). New York and Jerusalem: American Academy for Jewish Research, 1987.

"A Shi'i-Jewish 'Debate' (Munazara) in the Eighteenth Century." Journal of the American Oriental Society 119, no. 4 October- December 1999: 570-589.

Moruzzi, Norma Claire. "Strange Bedfellows: The Question of Lawrence Oliphant's Christian Zionism.” Modern Judaism 26, no. 1 2006: 55-73

Najmabadi, Afsaneh "The Erotic Vatan [Homeland] as Beloved and Mother: To Love, to Possess, and To Protect," Comparative Studies in Society and History 39, no. 3 (July 1997): 442-467. 
Nasr, Vali. The Shia Revival: How Conflicts within Islam Will Shape the Future. New York: W. W. Norton, 2006.

Newman, David. From Hitnachalut to Hitnatkut: The Impact of Gush Emunim and the Settlement Movement on Israeli Politics and Society. Israel Studies 10 no.3 (2005): 192-224

Novick, Peter. The Holocaust in American Life. Boston: Houghton Mifflin, 1999.

Parsi, Trita. "Israeli-Iranian Relations 1970-2001 - Ideological Calculus or Strategic Rivalry” PhD Diss., Johns Hopkins University, 2006. . Treacherous Alliance: The Secret Dealings of Israel, Iran, and the U.S. New Haven: Yale. University Press, 2007.

Peleg, Ilan. Begin's Foreign Policy, 1977-1983: Israel's Move to the Right. New York, Westport and London: Greenwood Press, 1987.

Peleg, Yaron. Orientalism and the Hebrew Imagination. Ithaca and London: Cornell, University Press, 2005.

Peli, Pinchas Hacohen. "Responses to Anti-Semitism in Midrashic Literature.” In, AntiSemitism in Times of Crisis, eds. Sander Gillman and Steven T. Katz,, 103-114. New York: New York University Press, 1991.

Peres, Shimon. The New Middle East. New York: Henry Holt, 1993.

Perkovich, George, et. al. "Universal Compliance: A Strategy for Nuclear Security.” (draft). Carnegie Endowment for International Peace, June, 2004. http://wmd.ceip.matrixgroup.net/UniversalCompliance.pdf

Podhoretz, Norman. “The Abandonment of Israel.” Commentary 62, no. 1 (July 1976): 23-31.

Polisar, Daniel. “Is Iran the Only Model for a Jewish State?” Azure 7 (Spring 1999).

Posch,Walter, ed. Iranian Challenges. Chaillot Paper 89. Paris: European Union Institute for Security Studies, May 2006.

Poulson, Stephen C. Socal Movements in Twentieth-Century Iran: Culture, Ideology and Mobilizing Frameworks. Lanham, MD: Lexington Books, 2005.

Pritchard, James B. ed. Ancient Near Eastern Texts Relating to the Old Testament, 3rd ed. Princeton: Princeton University Press, 1969. 
Ragussis, Michael. "Writing Nationalist History: England, the Conversion of the Jews, and Ivanhoe," ELN 60, no. 1 Spring 1993: 181-215.

Rahnema, Ali. An Islamic Utopian: A Political Biography of Ali Shariati. London and New York: I.B. Tauris, 1998.

Rakeffet-Rothkoff, Aaron, and Joseph Epstein, eds. The Rav: the World of Rabbi Joseph B. Soloveitchik. New York: Ktav, 1999.

Ram, Haggay. “’The Immemorial Iranian Nation?':” School Textbooks and Iranian Historical Memory in Revolutionary Iran.” Nations and Nationalism 6, no. 1 (2000): 67-90.

Ramazani, Rouhollah K. The Foreign Policy of Iran 1500-1941: A Developing Nation in World Affairs. Charlottesville: University of Virginia Press, 1966.

Ramazani, R.K. Revolutionary Iran: Challenge and Response in the Middle East. Baltimore: Johns Hopkins, 1986.

Raviv, Dan and Yossi Melman. Every Spy a Prince: The Complete History of Israel's Intelligence Community. Boston: Houghton Mifflin, 1990.

Rezun, Miron, ed. Iran at the Crossroads: Global Relations in a Turbulent Decade. Boulder Westview, 1990.

Rezun, Miron. “The ‘Pariah’ Sydrome.” In Rezun, 1990: 9-33.

Romanoff, Paul. Jewish Symbols on Ancient Jewish Coins (Continued). The Jewish Quarterly Review, New Series 34, no. 3 (January, 1944): 299-312.

Rubin, Barry. Paved with Good Intentions: The American Experience and Iran. New York: Penguin, 1981.

Rubinstein, Amnon. The Zionism Dream Revisited: From Herzl to Gush Emunim and Back. New York: Schocken, 1984.

Rubinstein, Elyakim. The Declaration of Independence as a Basic Document of the State of Israel. Israel Studies 3, no.1 1998: 195-210.

Sagi, Avi. Unity of Scripture Constituted through Jewish Traditions of Interpretation. In One Scripture or Many? Canon from Biblical, Theological , and Philosophical Perspectives, edited by Christine Helmer and Christof Landmesser, 186-216. Oxford: Oxford University Press, 2004. 
Said, Edward W. Orientalism. New York: Vintage Books, 1979.

Sariolghalam, Mahmood, Justice for All. The Washington Quarterly 24, no. 3 Summer 2001: 113-125.

Schwartz, Howard. Tree of Souls: The Mythology of Judaism. Oxford and New York: Oxford University Press, 2004.

Schwartz, Seth. Imperialism and Jewish Society, 200 BCE to 640 CE. Princeton and Oxford: Princeton University Press, 2001.

Segev, Samuel. The Iranian Triangle: The Untold Story of Israel's Role in the IranContra Affair. Translated by Haim Watzman, New York: Free Press, 1988.

Segev, Tom. 1949: The First Israelis. English language edited by Arlen Neil Weinstein. New York: Henry Holt, 1998.

. The Seventh Million: The Israelis and the Holocaust. Translated by Haim Watzman. New York: Henry Holt, 2001.

Shariati, Ali. Religion vs. Religion. Translated from the Persian by Laleh Bakhtiar. Chicago: ABC International Group, Inc., 2000.

Shavit, Yaacov. "Cyrus King of Persia and the Return to Zion: A Case of Neglected Memory." History and Memory 2, no. 1 1990: 51-83.

Shawcross, William. The Shah's Last Ride: The Fate of an Ally. New York: Simon and Schuster, 1988.

Shlaim, Avi. The Iron Wall: Israel and the Arab World. New York and London: W.W. Norton, 2001.

Simon, Uriel. The Place of the Bible in Israeli Society: From National Midrash to Existential Peshat, translated by David Louvish. Modern Judaism 19, no. 3 (October 1999), 217-239.

Smith, Morton. "II Isaiah and the Persians.” Journal of the American Oriental Society 83, no. 4 September-December 1963: 415-421.

Sobhani, Sohrab. The Pragmatic Entente: Israeli-Iranian Relations, 1948-1988. New York: Praeger, 1989.

Sofer, Sasson. Zionism and the Foundations of Israeli Diplomacy. Translated by Dorothea Shefet-Vanson. New York and Cambridge: Cambridge Univ. Press, 1998. 
Soroush, Abdolkarim. Reason, Freedom. and Democracy in Islam. Translated and edited by Mahmoud Sadri and Ahmad Sadri. New York: Oxford University Press, 2000.

Souresrafil, Behrouz, Khomeini and Israel. England, reprinted in U.S. [sic]: I Researchers, Inc., 1988.

Spearing, H. G. "Susa: the Eternal City of the East" In Wonders of the Past, edited by Sir J. A. Hammerton. Vol. II. New York: Wise and Co., 1937: 697-704.

Sprinzak, Ehud. Brother Against Brother: Violence and Extremism in Israeli Politics from the Altalena to the Rabin Assassination. New York: The Free Press, 1999.

Stadter, Philip A. "Fictional Narrative in the Cyropaideia." The American Journal of Philology 112, no. 4. Winter, 1991: 461-491.

Tavakoli-Targhi, Mohamad. Refashioning Iran: Orientalism, Occidentalism and Historiography. New York: Palgrave, 2001.

Wasserstrom, Steven Mark. Between Muslim and Jew: The Problem of Symbiosis under Early Islam. Princeton: Princeton University Press, 1995.

Weber, Timothy P. On the Road to Armageddon: How Evangelicals Became Israel's Best Friend. Grand Rapids, MI: Baker Academic, 2004.

Weinfeld, Moshe. The Promise of the Land: The Inheritance of the Land of Canaan by the Israelites. Berkeley: University of California Press, 1993. http://ark.cdlib.org/ark:/13030/ft596nb3tj/ (accessed August 4, 2007).

Weingrod, Alex. "Dry Bones: Nationalist and Symbolism in Contemporary Israel.” Anthropology Today, 11 no. 6 (December 1995): 7-12.

Winston, David. "The Iranian Component in the Bible, Apocrypha and Qumran,” History of Religions 5, No. 2 (Winter 1966): 183-216.

Wright, Robin. The Last Great Revolution: Turmoil and Transformation in Iran. New York: Alfred A. Knopf, 2000. Books, 1985.

Yanow, Dvora. Conducting Interpretive Policy Analysis. Thousand Oaks: Sage Publications, 2000. 
Yerushalmi, Yosef Hayim. Zakhor: Jewish History and Memory. Seattle: University of Washington Press, 1983.

Yishai, Yael. "Public Ideas and Public Policy: Abortion Politics in Four Democracies." Comparative Politics 25, no. 2. January 1993: 207-228.

Zeitlin, Irving M. Ancient Judaism: Biblical Criticism from Max Weber to the Present. Cambridge: Polity Press, 1984.

Zertal, Idith. "From the People's Hall to the Wailing Wall: A Study in Memory, Fear, and War.” Representations, no. 69, Special Issue: Grounds for Remembering. Winter, 2000: 96-126.

Zerubavel, Yael. Recovered Roots: Collective Memory and the Making of Israeli National Tradition. Chicago: University of Chicago Press, 1995.

Ziemke, Caroline F. "The National Myth and Strategic Personality of Iran: A Counterproliferation Perspective." In The Coming Crisis: Nuclear Proliferation, U.S. Interests, and World Order, edited by Victor A. Utgoff, 87-121. Cambridge: MIT Press, 2000.

Zubaida, Sami. “An Islamic State? The Case of Iran,” Middle East Report, no. 153, Islam and the State July-August 1988: 3-7. 
VITA

\section{MARSHA B. COHEN}

Born: Bronx, NY

Bachelor of Arts: Hebrew University, Jerusalem

1999-present $\quad$ Adjunct Lecturer, Dept. of International Relations

Florida International University

Miami, FL. 33199

1998-present Instructor, Florence Melton Adult Mini-School

Miami, FL.

\section{PUBLICATIONS AND PRESENTATIONS}

Middle East and Central Asia (MECA) Conference, Salt Lake City, UT, Sept. 7-9, 2006. Paper: “The U.S. "War on Terror” and Iranian Foreign Policy Objectives.”

International Studies Association South, Conference, Columbia, SC, Oct. 23, 2004.

Paper: "God, Grievance and the Bomb: Israeli and Iranian Challenges to Nuclear NonProliferation Norms.”

Special Studies course instructor, Chautauqua Institution, Chautauqua, NY, Summer 2004. June 28-July2: “The 'Clash of Civilizations’ Argument and its Critics.” Aug. 16-20: "Joseph in the Bible and the Quran.”

Center for Iranian Research and Analysis Conference, Orlando, FL April 8-10, 2004. Paper: "Israel and Iran: A Comparative Study of the Rhetorical Use of the "War on Terror' to Achieve Foreign Policy Goals.” 